\title{
Economics in Sweden
}

Economics in Sweden contains the results of one of the most comprehensive attempts to evaluate research in economics ever undertaken. A team of Swedish and international researchers, including Avinash K. Dixit, Seppo Honkapohja and Robert M. Solow, examined the structure of economics in Sweden and the results it produces. They identified postgraduate education as a key area, and their findings will be of particular relevance at a time when many countries are restructuring their graduate education programmes.

Sweden has made a distinctive contribution to the development of economics and the book also considers the extent to which it still contributes to an increasingly international discipline. The book will be of interest not only for its specific contributions but also for its insights into the evaluation procedure.

Lars Engwall has been Professor of Business Administration at Uppsala University since 1981. He has extensive research experience in both Europe and the USA. 



\section{Economics in Sweden An Evaluation of Swedish Research in Economics}

Edited by Lars Engwall

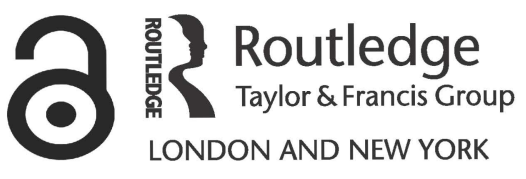


First published 1992 by Routledge

Published 2017 by Routledge

2 Park Square, Milton Park, Abingdon, Oxon OX14 4RN

711 Third Avenue, New York, NY 10017, USA

Routledge is an imprint of the Taylor \& Francis Group,

an informa business

Copyright $\odot 1992$ Lars Engwall

Typeset in 10/12 point Times by Witwell Ltd, Southport

The Open Access version of this book, available at www.tandfebooks.com, has been made available under a Creative Commons Attribution-Non Commercial-No Derivatives 4.0 license.

British Library Cataloguing in Publication Data

A catalogue record for this book is available from the British Library

ISBN 978-0-415-07256-4 (hbk)

Library of Congress Cataloging-in-Publication Data

Economics in Sweden : an evaluation of Swedish research in economics /

Lars Engwall, ed. ; with contributions by Avinash K. Dixit ... [et

al.].

p. $\quad \mathrm{cm}$.

Includes bibliographical references (p. ) and indexes.

ISBN 0-415-07256-5

1. Economics-Research-Sweden-Evaluation. 2. EconomicsSweden.

I. Engwall, Lars, 1942HB74.9.S8E26

1992

II. Dixit, Avinash K.

$330^{\prime} .09485-\mathrm{dc} 20$

Publisher's Note

The publisher has gone to great lengths to ensure the quality of this reprint but points out that some imperfections in the original may be apparent 


\section{Contents}

Figures and Tables $\quad$ ix

Contributors xii

Abbreviations $\quad \mathrm{xv}$

Part I Introduction and background studies

1 Points of departure 3

Lars Engwall

Background 3

A framework for the study 5

The evaluation process $\quad 8$

The results of the evaluation $\quad 11$

Evaluating the evaluation $\quad 16$

2 Economics the Swedish way 1889-1989 19

Lars Jonung (assisted by Elving Gunnarsson)

Introduction 19

The development of the market for professors 20

Becoming a professor 28

Intramural activities of the professors 33

Extramural activities of the professors

Foreign influences on Swedish professors 45

Final reflections $\quad 48$

3 The economics of Swedish economics in the 1980s 49

Peter Stenkula and Lars Engwall

The Swedish system for allocating research grants 49

Methodological issues $\quad 53$

Faculty grants $\quad 54$

External research grants $\quad 59$ 
vi Contents

Total resources to economics research 62

Conclusions $\quad 65$

4 Recruiting a new generation $\quad 67$

Eskil Wadensjö

Introduction $\quad 67$

The Swedish system of postgraduate education $\quad 68$

The small number of theses $\quad 71$

An ageing population of Ph.D. students $\quad 80$

Few women with Ph.D. degrees 83

Ph.D. degrees in economics awarded to Swedish citizens
in the United States

The form and content of the theses 86

The faculty opponent 88

The topics of the theses 91

The labour market for doctors of economics 94

$\begin{array}{lr}\text { Conclusions } & 102\end{array}$

5 Swedish economics on the international scene 104

Olle Persson, Peter Stern and Elving Gunnarsson

Introduction $\quad 104$

Data material $\quad 106$

Publication activity and journal selection $\quad 107$

Relations with the intellectual heritage $\quad 116$

Research profiles $\quad 118$

$\begin{array}{ll}\text { Conclusions } & 125\end{array}$

Part II The views of the international evaluation committee

6 Swedish economics in the 1980s 129

Avinash K. Dixit, Seppo Honkapohja and Robert M. Solow

Swedish economics after the Stockholm school 129

Labour economics $\quad 130$

Natural resources 133

Interregional economics $\quad 135$

International economics $\quad 135$

$\begin{array}{ll}\text { Public finance } & 138\end{array}$

Econometrics 139

Macro and monetary economics $\quad 140$

Microeconomics $\quad 142$

Conclusions $\quad 144$ 
Contents vii

7 Organization of research 145

Avinash K. Dixit, Seppo Honkapohja and Robert M. Solow

An overview

145

University departments

148

University-based research institutes 151

Non-university-based research institutes 153

Research funding 155

The general profile of research 157

$\begin{array}{ll}\text { Conclusions } & 157\end{array}$

8 Postgraduate education in Sweden 159

Avinash K. Dixit, Seppo Honkapohja and Robert M. Solow

Introduction 159

$\begin{array}{lr}\text { Scale } & 160\end{array}$

Incentives $\quad 164$

$\begin{array}{ll}\text { Tradition } & 168\end{array}$

Conclusions $\quad 170$

9 Recommendations 171

Avinash K. Dixit, Seppo Honkapohja and Robert M. Solow

Summary of good and bad features of the system 171

Recommendations concerning organization of research $\quad 174$

Recommendations concerning postgraduate training $\quad 180$

Concluding remarks 185

Appendix A: Time schedule for the evaluation project 187

Appendix B: Professors of economics in Sweden 1741-1989 189

Elving Gunnarsson

Introduction 189

Ancestors (1741-1889) 190

Modern age (1889-1989) 191

Appendix C: The role of institutions 196

Lars Jonung

The Stockholm School of Economics 196

Lund University 198

The Institute for International Economic
Studies 


\section{viii Contents}

Appendix D: Doctoral theses in economics in Sweden

1895-1989

200

Eskil Wadensjö

Introduction

200

Old Ph.D. degrees (1895-1973)

200

New Ph.D. degrees (1970-89)

Notes and references

Glossary

275

Index

278 


\section{Figures and Tables}

\section{FIGURES}

1.1 The stakeholders 7

1.2 The research system $\quad 7$

1.3 Studies undertaken 10

1.4 Composition of the book 12

2.1 The number of chairs and departments of economics in Sweden 1889-1989

3.1 Distribution of faculty grants $1980-1$ to $1989-90$ (1989-90 prices)

3.2 Distribution of external grants between university cities 1980-1 to 1989-90

3.3 Distribution of external grants $1980-1$ to $1989-90$ (1989-90 prices)

3.4 Distribution of total research grants $1980-1$ to $1989-90$ (1989-90 prices)

4.1 Histogram over year of birth of those granted a Ph.D. in economics 1970-89

5.1 Percentage share of world output of articles written in English in economic journals 1973-89 - Sweden,

West Germany and France, three-year weighted averages 108

7.1 The market for doctors of economics

7.2 Organization of research

\section{TABLES}

2.1 Occupants of chairs in economics 1889-1989

2.2 The establishment of departments with professors of economics 1889-1989

2.3 The four phases of economics in Sweden 1889-1989: 


\section{$\mathrm{x}$ Figures and Tables}

a stylized overview $\quad 29$

2.4 Age at the first appointment as professors in economics or related subjects in Sweden 1889-1989 34

2.5 Length of service as professor, 25 years or more 35

2.6 Number of newspaper articles published by Knut Wicksell, Gustav Cassel, Eli Heckscher and Bertil Ohlin

2.7 Professors in economics as members of Parliament

2.8 The publication record of 37 Swedish professors in economics living in 1989

2.9 Percentage distribution of citations by language of source in Ekonomisk tidskrift and its successors: 1900, 1935, 1970 and 1988

3.1 Faculty grants $1980-1$ to $1989-90$ (KSEK) 55

3.2 Faculty grants to economics and all social sciences in 1980-1 to $1989-90$ at $1989-90$ prices (KSEK)

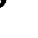
5

3.3 Relationship between total faculty grants, economics

faculty grants and gross national product 58

3.4 External financing of economics research 1980-1 to 1989-90 (KSEK)

3.5 Total financing of economics research 1980-1 to 1989-90 (KSEK)

4.1 First-time registered postgraduate students in economics 1972-3 to $1989-90$

4.2 Numbers obtaining Ph.D. degrees in economics by year of examination and university

4.3 Number of theses in economics 1895-1989 by type of degree and decade

4.4 Theses in economics $1895-1989$ by type of degree and university

4.5 Average number of registered Ph.D. students and total number of students registered at least once as Ph.D. students in economics

4.6 Financial support for Ph.D. theses as indicated by prefaces to theses

4.7 Average age of those completing theses in economics 80

4.8 Candidates' age at examination over time

(Age $=a+b *$ time)

4.9 Median age of research students in economics

4.10 Median study time for a new Ph.D. degree in economics 1974-90 in number of terms (two terms per calendar year) 83

4.11 Theses in economics by type of degree and sex

4.12 Gender and age of Swedish citizens receiving Ph.D. 
degree in economics from the United States 85

4.13 Theses in economics by type of degree and language $\quad 88$

4.14 New Ph.D. theses $1970-89$ by language 88

4.15 Faculty opponent at oral defence of theses in economics according to type of degree and origin $\quad 90$

4.16 Faculty opponent for Ph.D. oral defence in economics according to the new system

91

4.17 Theses (new Ph.D.) 1970-89 by subject and university 93

4.18 Theses in economics $1895-1989$ by type of degree and subject

4.19 Present occupation (November 1990) according to sector 95

4.20 Wage income and total earnings from employment in 1989 for those who have received a Ph.D. or Licentiate degree in economics in Sweden 1970-89

4.21 Earnings equations. Earnings in 1989 for those who have received a Ph.D. in economics in Sweden 1970-89 98

5.1 Articles written in English in economic journals 1973-89 - Sweden, West Germany and France

5.2 Distribution of authors by number of articles in Swedish economics 1973-89

5.3 Distribution of Swedish articles by journal during 1973-89 112

5.4 Percentage of articles in economic core journals 1973-89 114

5.5 Swedish citations in Handbooks in Economics 115

5.6 Number of articles 1973-89 citing Nobel laureates $\quad 117$

5.7 Citations 1973-89 to major schools of thought in macroeconomics. Relative Citation Ratio (RCR)

5.8 Subject classification of Swedish SSCI-articles 1973-89 in economics by city

5.9 Subject classification of Stockholm articles 1973-89 in economics by major institution

5.10 Swedish and world articles 1973-89 in economics classified by major field

7.1 Staff in departments of economics, 1 July 1990 


\section{Contributors}

Avinash K. Dixit has been Professor of Economics at Princeton University since 1981. Before this he held academic posts at the University of California at Berkeley (1968-9), Balliol College, Oxford (1970-4) and Warwick University (1975-80). His education includes a BA in Mathematics from Cambridge University (1965), and a Ph.D. in Economics from MIT (1968). His current area of research is the theory of investment under uncertainty and its applications. He has contributed to the theories of industrial organization, international trade, public finance, and economic growth and development in various journal articles as well as in Optimization in Economic Theory (Oxford University Press, 1976, second edition 1990), The Theory of Equilibrium Growth (Oxford University Press, 1976), Theory of International Trade (with Victor Norman, Cambridge University Press, 1980), and Thinking Strategically: The Competitive Edge in Business, Politics, and Everyday Life (with Barry Nalebuff, Norton, 1991).

Lars Engwall has been Professor of Business Administration at Uppsala University since 1981. He has a Ph.D. from Stockholm University, has held research posts at Carnegie-Mellon University, University of California at Berkeley and the European Institute of Advanced Studies in Management, Brussels, and is a member of the Royal Swedish Academy of Sciences. His research, which has focused on general management problems, has been presented in a number of journal articles and books. The latter include Models of Industrial Structure (Lexington, MA: Lexington Books, 1973), Newspapers as Organizations (Farnborough: Saxon House, 1978) and Mercury Meets Minerva (London: Pergamon Press, forthcoming).

Elving Gunnarsson is a lecturer (högskolelektor) in the Department of Business Studies at Uppsala University. He gained a Ph.D. from the 


\section{Contributors xiii}

same Department for a thesis on the development of business education in Sweden before the foundation of the Stockholm School of Economics (Frän Hansa till Handelshögskola, From the Hanseatic League to a School of Economics, 1988). His present research interests focus on the interaction and demarcation between economics and business administration as academic disciplines.

Seppo Honkapohja is currently Research Professor at the Academy of Finland, on leave from the University of Helsinki, and earlier at the Turku School of Economics. He has previously been Scientific Director of the Yrjö Jahnsson Foundation and Managing Editor of the Scandinavian Journal of Economics. He is a member of the Academia Europaea. His main research interest is economic theory, especially macroeconomics and monetary economics. $\mathrm{He}$ has published numerous articles in international journals and edited several books including Frontiers of Economics (1985 with Kenneth Arrow), Information and Incentives in Organizations (1989) and The State of Macroeconomics (1990).

Lars Jonung has been Professor of Economics and Economic Policy at the Stockholm School of Economics since 1988. He received his undergraduate training at Lund University and his Ph.D. from the University of California, Los Angeles, in 1975. Monetary economics, Swedish economic thought, macroeconomic policy and inflationary expectations are his main fields of research. He has published several books and articles in Swedish and English, including The Long Run Behavior of the Velocity of Money (1987 with M. D. Bordo), The Political Economy of Price Controls (1990) and The Stockholm School of Economics Revisited (ed. 1991). He is currently working on a study of Swedish monetary policy 1945-90. In March 1992 Lars Jonung assumed a position as chief economic adviser to the Prime Minister of Sweden.

Olle Persson is docent in sociology at Umeå University, where he received his $\mathrm{Ph} . \mathrm{D}$. in 1980 . His main research interest is the study of communication in science and technology. $\mathrm{He}$ is also one of the founders of the Inforsk research group. Over the last ten years he has contributed to the development of science indicators using bibliometric techniques.

Robert M. Solow is Professor of Economics at Massachusetts Institute of Technology, where he has been since receiving his BA, MA, and Ph.D. degrees from Harvard University. He has published widely on the theory of capital and economic growth, macroeco- 


\section{xiv Contributors}

nomics, the theory of land use, and the economics of exhaustible resources. His publications include Linear Programming and Economic Analysis (1958, with R. Dorfman and P. A. Samuelson), Capital Theory and Rate of Return (1963), Nature and Sources of Unemployment in the United States (1964), Price Expectations and the Behavior of the Price Level (1970), and Growth Theory. An Exposition (1970). He holds honorary degrees from a number of American and other universities and received the Alfred Nobel Memorial Prize in Economic Sciences for 1987.

Peter Stenkula is lecturer (högskolelektor) in Economics and Head of the Nordic Economic Research Council. His research has focused on economics of education. His publications include Byggforskningen en översyn och utvärdering (Building Research - An Overview and Evaluation, 1982), Tre studier över resursanvändning $i$ högskolan (Three Studies of Resource Use in Higher Education, 1985), and Produktions-, kostnads- och produktivitetsutvecklingen inom den offentligt finansierade utbildningssektorn 1960-1980 (The Development of Production, Costs and Productivity in the Public Educational Sector 1960-1980; 1986).

Peter Stern is a research assistant and Ph.D. student in sociology at Umeå University. He is a member of the Inforsk research group at that university. His research interest is in the sociology of sciences and his current work concerns the interplay between social and cognitive structures in scientific disciplines.

Eskil Wadensjö received his Ph.D. from Lund University in 1972 for his dissertation on The Economic Effects of Immigration to Sweden. He was a lecturer in the Department of Economics at Lund University until 1980 when he was appointed Professor of Economics at the Swedish Institute for Social Research at Stockholm University. His research is mainly in the area of labour economics and labour market policy. His publications include Unequal Treatment. A Study in the Neo-Classical Theory of Discrimination (1989 with Mats Lundahl). 


\title{
Abbreviations
}

\author{
ALC Centre for Working Life \\ AMS Labour Market Board \\ BFR Swedish Council for Building Research \\ CERUM Centre for Regional Studies at Umeå University \\ EFI Economic Research Institute at the Stockholm School of \\ Economics \\ EFA Delegation for Labour Market Policy Research \\ EFN Energy Research Commission \\ FIEF Trade Union Institute for Economic Research \\ FRN Coordinating Board of the Swedish Research Councils \\ GU Gothenburg University \\ HHS Stockholm School of Economics \\ HSFR Swedish Council for Research in the Humanities and the \\ Social Sciences \\ IUI Industrial Institute for Economic and Social Research \\ IHE Institute for Health Economics at Lund University \\ IIES Institute of International Economic Studies at Stockholm \\ University \\ JEL Journal of Economic Literature \\ KI National Institute of Economic Research \\ KSEK Thousand Swedish Crowns (approximately equivalent to \\ 90 pound sterling or 180 US dollars, spring 1991) \\ KVA Swedish Royal Academy of Sciences \\ LO Swedish Confederation of Labour \\ LU Lund University \\ MDS Multi-dimensional Scaling \\ MSEK Million Swedish Crowns (approximately equivalent to \\ 90,000 pound sterling or 180,000 US dollars, spring 1991) \\ RJ Bank of Sweden Tercentenary Foundation \\ SAREC Swedish Agency for Research Cooperation with
}




\section{xvi Abbreviations}

\section{Developing Countries}

SEK Swedish Crowns (approximately equivalent to 0.09 pounds sterling or 0.18 US dollars, spring 1991)

SFR Swedish Council for Social Research

SJFR Swedish Council for Research in Forestry and Agriculture

SOFI Swedish Institute for Social Research

SOU Government Commission Reports

SCB Statistics Sweden - Sweden's central bureau of statistics

SSCI Social Science Citation Index

SU Stockholm University

SNS Centre for Business and Policy Studies

SLU Swedish Agricultural University

UmU Umeå University

UHÄ Office of Swedish Higher Education

UU Uppsala University 


\section{Part I \\ Introduction and background studies}





\title{
1 Points of departure
}

\author{
Lars Engwall
}

\section{BACKGROUND}

The neoclassical theory of the firm concentrates on the price and output decisions of a single decision-maker in response to market conditions. More recent contributions, on the other hand, have introduced hierarchical aspects within the firm (cf. e.g. Alchian and Demsetz 1972, Fama and Jensen 1983). According to this second view, contracts between principals and agents govern the division of responsibility. This in turn suggests the need for the principal to control the performance of the agent. This sort of situation in fact occurs in most contexts in society today. Even a long-term activity such as research has been made increasingly subject to various evaluation procedures of this kind:

In an era of increasing costs of scientific research and stronger demands for selectivity in which directions will be funded, evaluations serve a multiple purpose: they legitimize activities, provide a tool to select targets and help to identify problems that hinder the effectiveness of the system. Even if the evaluations do not produce sizeable impacts, they supply a useful tool that is difficult to replace.

(Luukkonen-Gronow 1989a: 241)

Thus the rising cost of research has been one important factor behind the boom in evaluations in all areas. Another has been the need to select and define priorities in slowly growing economies. ${ }^{\prime}$ A third factor seems to be the rapid penetration of modern management principles into many organizations (Engwall 1992), which has implied a growing tendency to focus on efficiency.

Research evaluation has been the subject of particular attention in the United Kingdom (cf. Irvine 1989, Hill 1989) but the Scandinavian countries have also been quite active in this field (Luukkonen- 


\section{Introduction and background studies}

Gronow, 1989b). For some years a variety of government bills in Sweden, for instance, have been stressing the importance of finding appropriate evaluation procedures. Some of the responsibility for this task has been assigned to the research councils, which distribute government research grants by way of a peer review system. ${ }^{2}$ Of these research councils the Council for Research in the Natural Sciences (NFR) has been the most active. It began making evaluations of this kind as early as the late $1970 \mathrm{~s}$, and has since then covered most areas within its jurisdiction (Government Bill 1981/82:106, p. 37). It has even scrutinized its own evaluations (NFR 1981).

The Council for Research in the Humanities and Social Sciences (HSFR) at first adopted rather a cautious stand on the feasibility of evaluations, motivated primarily by reference to the differences between the natural and the human sciences. But fairly early on two scholars, one Danish and one Norwegian, were asked to make an inventory of Swedish research on the subject of social organization and public administration. In their subsequent report, the then Secretary General of HSFR pointed out in a foreword that "it is not a matter of evaluation but a comprehensive inventory [. . . ] which can serve as a basis for strict evaluation in the future'(Eliassen and Pedersen 1984: 5 , our translation). However, this project was later succeeded by evaluations of research in the humanities and the social sciences. Thus during the late 1980s and, in collaboration with the Office of Swedish Higher Education (UHÄ), HSFR engaged a number of distinguished international scholars to examine the state of the disciplines of sociology and history (cf. Allardt, Lysgaard and Bøttger Sørensen 1988 and Danielsen et al. 1988). In a new series of similar studies HSFR has selected economics, linguistics and psychology for scrutiny.

One important reason for choosing economics was that the conditions for a study seemed particularly favourable. Blaug (1980), following Lakatos (1978), has stressed the existence of a hard core in this discipline, around which a number of developments have occurred. ${ }^{3}$ Despite the fact that some might consider economics to be 'the imperial science' (Stigler 1984), and others might call for more variety within the discipline (cf. Caldwell 1982; McCloskey 1983, 1986 and the contributions in Klamer, McCloskey and Solow 1988), the boundaries of the discipline are still relatively distinct as well as being similar internationally. Colander (1989a: 32) thus claims that 'economics is amazingly coherent compared to the other social sciences. It has a "grand theory" accepted by a large majority of the profession, and an accepted methodology." Similarly, the Swedish economist Ragnar Bentzel says: 
Economic theory is by nature very analytically and internationally oriented. The conclusions are obtained as implications of specific assumptions and the scope for subjective judgements is limited primarily to setting up these assumptions. As a rule the conclusions have general validity for all countries with similar economic system.

(Bentzel 1986: 87; our translation)

The main purpose of the present evaluation project, under the auspices of HSFR, is to locate Swedish economic research in an international setting. The task is thus related to the discussion in Portes (1987) on economics in Europe. The purpose is not to present a ranking order of economics departments of the kind published in articles such as Graves, Marchand and Thompson (1982) or Hirsch et al. (1984). Rather, the intention is to set Swedish economics in a wider context and, more generally, to identify its strengths and weaknesses. Nor, obviously, is the purpose to evaluate economics as such, i.e. whether economics generally is in good or bad shape (cf. Coats and Colander 1989, Clower 1989) or whether economics is 'a Science, with a capital $S$ [. . . or whether it] should try hard to be scientific with a small $s$, (Solow 1990: 199-200).

The results of the evaluation should then facilitate the definition of Sweden's comparative advantages as well as feasible routes for maintaining and strengthening them. This does not mean that HSFR is aiming at a concentration of research to a few narrowly defined areas in which Swedes could be in the forefront internationally. ${ }^{5}$ The intention is rather to provide a solid basis for discussing the future of Swedish economic research. In this respect the present project belongs to a tradition that the Dutch social scientist Stewart Blume has referred to as 'the famous Nordic approach', whereby 'international visitation panels [are used] not just to decide who was bad but, more importantly, to find a way of improving everyone' (Blume, 1989: 217).

\section{A FRAMEWORK FOR THE STUDY}

One important purpose of evaluations is to find out how allocated resources have been utilized, i.e. what output has resulted from a given input. In looking into this question the evaluator faces the problem of identifying relationships between cause and effect. A common approach has consequently been to adopt quasi-experimental designs in order to isolate the system under study or to reduce the number of intervening variables (cf. e.g. Cook and Campbell 1979). But others, for instance Lincoln and Guba (1985), have claimed that although 


\section{Introduction and background studies}

technically elegant, such approaches miss important features in the evaluation. They therefore advocate the use of various kinds of qualitative methods. This also means that not only do evaluators observe the behaviour of participants in the system under study, but they also regard these participants as stakeholders with whom they interact. Recently this naturalistic approach and the experimental approach have both been criticized by Chen (1990) as being too method-driven, and the development of more theoretical foundations for the evaluations has been called for. A plea for the integration of the earlier approaches has also been made. There are thus four basic values that are regarded as playing a particularly important role in evaluations: responsiveness, objectivity, trustworthiness and generalizablity (Chen 1990: 61-5). In other words the evaluation:

1 should be sensitive to the needs of the stakeholders;

2 should not be biased;

3 should be accepted by the stakeholders; and

4 should be useful for future action.

Needless to say, as Chen (1990: 72) has pointed out, these four values imply conflicting goals which have to be balanced.

The approach in the present evaluation has been not dissimilar to that recommended by Chen, i.e. to develop a theoretical foundation, to enter into a balanced interaction with stakeholders, and to combine different empirical methods. In connection with the first of these points we come up against the principal-agency problem referred to above. This problem is complicated here in that it comprises principals and agents at different levels (figure 1.1). The ultimate agents are of course the researchers, who obtain funds for their research work from different sources, while the ultimate principals consist of private donors and the government. Of these two, the role of the former as principals can be questioned, since they seldom act together for evaluation purposes. Government, on the other hand, assumes prime responsibility for research policy in the country, and thus emerges as an important stakeholder. The task assigned to the Research Councils and to the Office of Swedish Higher Education (UHÄ) to undertake evaluations bears witness to this. The relationship between the government research-granting bodies and the researchers differs from that of the Office of Swedish Higher Education, however, due to the role they play in screening applications and allocating grants. The agents of the government thus become the principals of the researchers. For our present purposes it is enough to establish that the system we are evaluating is a complex one and that the funding of the 


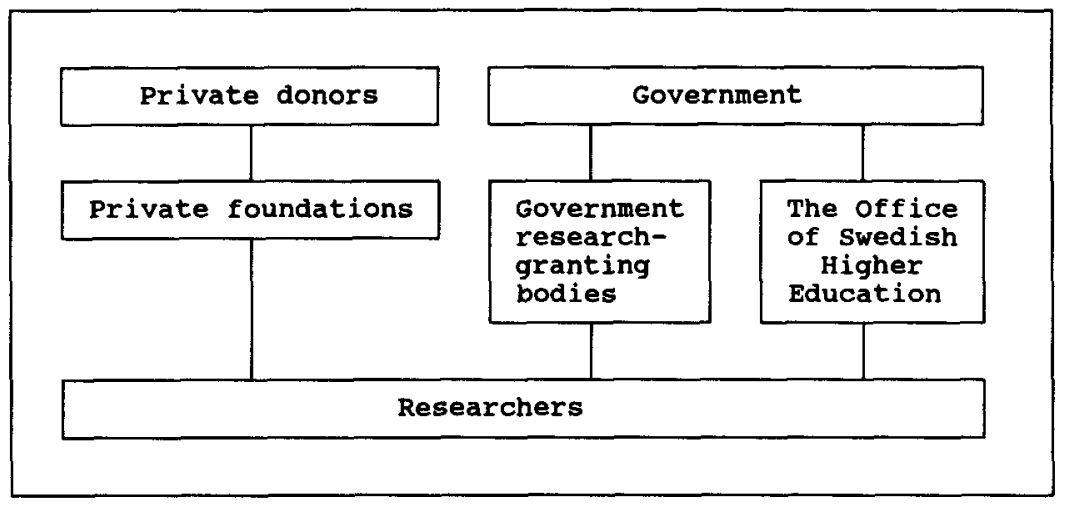

Figure 1.1 The stakeholders

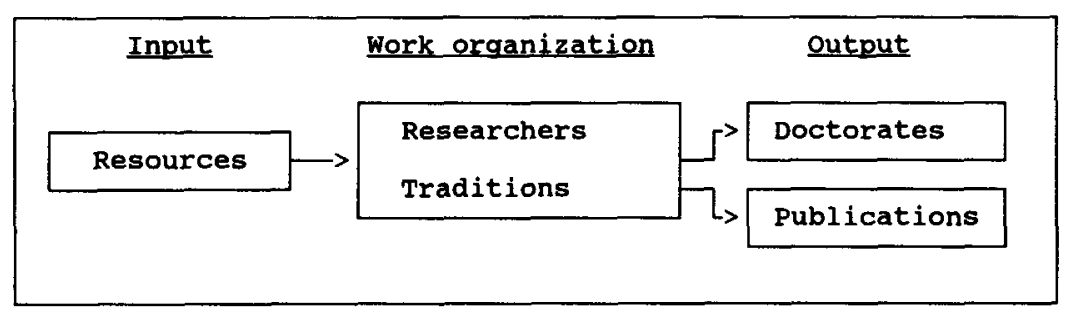

Figure 1.2 The research system

research output comes from several sources. The different actors included in figure 1.1 are all stakeholders in the evaluation. For practical purposes we can identify two groups of stakeholders: the providers of research grants and the researchers. ${ }^{6}$ In pursuing the evaluation the former have been represented by HSFR and the latter by representatives of the economics profession in Sweden.

Turning now to the research system we will focus on input, work organization and output (figure 1.2). The first of these variables, input, consists of the financial resources which are provided and against which the research output can be evaluated. ${ }^{7}$ In examining this part of the system it is important to adopt a long view. Looking at research performance today, we have to know how resources were allocated in the past. This is particularly important, since the results of research work are often long in coming.

Important aspects of the research system include the present 


\section{Introduction and background studies}

infrastructure in terms of institutions, rules, working conditions, etc. Further it is important to consider the research activities at the microlevel, i.e. how economics researchers select their research topics and how they approach their selected tasks. Since organizational research has increasingly tended to stress the necessity of considering the restrictions imposed on organizational activities by historical conditions (cf. e.g. Kimberly et al. 1980), it is equally important to consider the traditions of the discipline itself. ${ }^{8}$ These must be included if we are to understand the functioning of the system.

In the case of output it is again important to take a longer view. It is not enough to look at current research; this must also be related to research in the past. And here too particular attention must be paid to the opportunities for feeding young scholars into the system, since the raising of a new generation is one of the basic conditions of future work in the field.' A system that is geared to working in the longer term thus has to have an efficient element of postgraduate education. ${ }^{10}$ But the analysis must of course also look at current research output, i.e. in what way and to what extent the research results have been spread to a wider audience. This is important, since we can assume that the impact of the research will depend on how many people have had the opportunity to acquaint themselves with its results. In this context a distinction is usually made between the internal and external value of the research (cf. e.g. Bromley 1972, Weinberg 1963). In our present study we will concentrate on the former, i.e. the extent to which the research has influenced the rest of the research community."

\section{THE EVALUATION PROCESS}

\section{Selecting institutions and evaluators}

Having defined stakeholders and the research system in general we now have a basis for making two crucial decisions regarding the scope of the study and the selection of evaluators: which researchers are to be subjected to evaluation, and who should be selected to make the evaluation? Both these issues were solved in conjunction with representatives of the discipline, and bearing in mind the call for 'a fourth generation evaluation' by Guba and Lincoln (1989). Our approach included separate informal contacts with representatives of the different economics departments and a formal meeting with the representatives as a group at the HSFR headquarters. This last dealt with the design of the evaluation, relevant institutions to include and possible evaluators. 
Our specification of the scope of the study resulted in the selection of eleven institutions. The first to be selected were the departments of economics of the five universities together with the Stockholm School of Economics. To these six institutions were added the Institute for International Economic Studies (IIES) and the Swedish Institute for Social Research (SOFI) both at Stockholm University, and three nonuniversity institutions: the National Institute of Economic Research (Konjunkturinstitutet), the Trade Union Institute for Economic Research (Fackföreningsrörelsens institut för ekonomisk forskning), and the Industrial Institute for Economic and Social Research (Industrins utredningsinstitut). ${ }^{12}$

The choice of evaluators was made after a formal meeting with representatives of the various academic institutions at HSFR. ${ }^{13}$ Before the meeting a number of special fields had already been identified on a basis of earlier surveys of Swedish economics research (cf. Landgren 1957, Jungenfelt and Lindbeck 1973, Bentzel 1986, Puu 1990, Ysander 1990). Using these subject areas as a frame of reference we then asked representatives of the different departments to suggest candidates for the international evaluation committee. Their suggestions were later presented to the formal meeting. After adding a few more names, the participants at the meeting were able to agree on a group of three people as their first choice. ${ }^{14}$ Since the credibility of the evaluators is crucial to the success of any evaluation project (cf. e.g. Alkin 1990: 2932 and 164), the accomplishment of this task was considered extremely important. It was therefore particularly valuable that the selected evaluators - Professor Avinash K. Dixit of Princeton University; Professor Seppo Honkapohja, then at the Turku School of Economics and later at the Academy of Finland and Helsinki University; and Professor Robert M. Solow of the Massachussets Institute of Technology - all agreed to take part in the project. They were formally appointed by HSFR in March 1989, but because of their earlier commitments, it was about six months before they could start work on the project.

\section{Studies undertaken}

In order to address the various components of the research system (figure 1.2), a number of studies were undertaken (figure 1.3). Three approaches were used in exploring the work organization. First, a background study was commissioned on the historical traditions of Swedish economic research. Second, the eleven selected institutions were asked to submit material that would 'provide an adequate picture 
10 Introduction and background studies

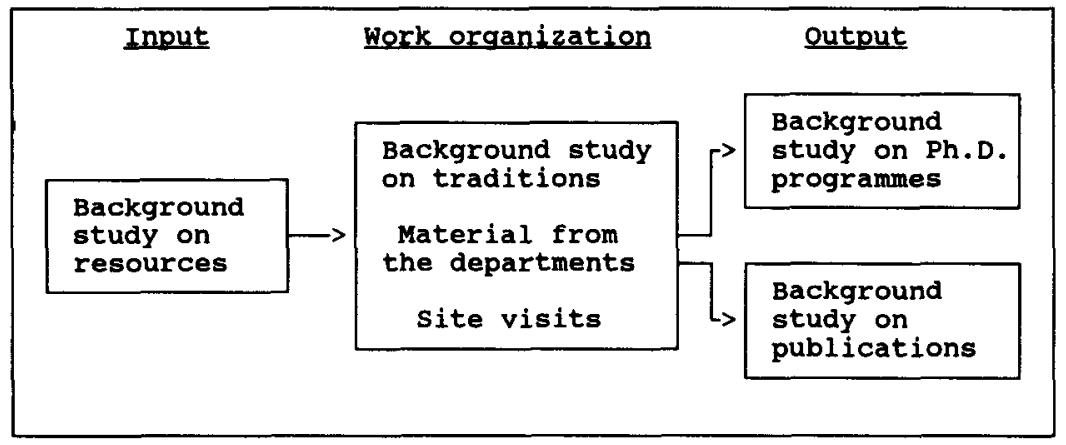

Figure 1.3 Studies undertaken

of the research activities in the department particularly during the 1970s and 1980s'. Third, the international evaluation committee made site visits to all the selected institutions in March 1990 (cf. Appendix A).

As regards the site visits: the time available allowed one day only per university, with the exception of Stockholm University, which houses two research institutes in addition to its own Department of Economics. During the site visits the institutions presented their research programmes in the mornings according to their own choice, while the afternoons were devoted to informal discussions with faculty staff and doctoral students. Despite the limited time the site visits proved to be highly informative. They also seemed to be appreciated by the institutions themselves, just as an earlier evaluation undertaken by the Swedish Natural Science Research Council 'was highly valued by the scientists because it gave them the chance to talk at length with international experts in their field about their problems' (Blume 1989: 217).

In order to portray the input and output components of the system three further background studies were commissioned. These concerned the financing of Swedish economic research, the doctoral programmes and the publication practices of Swedish economists. Since knowledge of the Swedish system was important in carrying out the four background studies, Swedes were engaged for the task. Draft reports were submitted to the international evaluation committee along the way: outlines in the autumn of 1989 , early drafts before the site visits, and later drafts at the committee meeting in December 1990. In this way the reports have constituted a continuous input into the evaluation. 


\section{The process in full}

After the site visits were completed the group worked on analysing the information obtained and writing the report. This work took about a year, including several feedback rounds (cf. Appendix A). A preliminary copy-edited version of the manuscript was then discussed with representatives of the departments and research institutes in September $1991 .{ }^{15}$ The whole project thus took about three years from the initial plans to the final manuscript. This may seem rather a long time, but perhaps less so if we consider the scope and importance of the mission. An important consideration was that the evaluation should comprise not only projects within a particular area but also the discipline of economics as a whole. This endowed the study with wider importance and made a very thorough approach necessary. ${ }^{16}$ In fact it might be questioned whether the study has explored Swedish economic research in sufficient depth. People might wonder whether it is possible to make evaluations after reading some background studies and making brief site visits. The answer to this is that even before the mission began the experts represented a considerable amount of knowledge about Swedish economics. Also, and this is very important, they were selected by the profession itself. They are people trusted by their peers. Thus it seems reasonable to assume that a combination of a fairly easy time schedule, a series of background studies and a band of trusted experts has provided a sound basis for the accomplishment of a difficult task.

\section{THE RESULTS OF THE EVALUATION}

This book, the ultimate output of the evaluation, contains nine chapters (figure 1.4). This introductory chapter is followed by the four background studies on work organization, input and output (Chapters 2-5). Together these five chapters constitute the first part of the book, while the second part comprises the views of the international evaluation committee. The committee has elaborated on various aspects of the output (Chapter 6) and on work organization (Chapters 7 and 8). In Chapter 9 they have made some recommendations.

Chapter 2, written by Lars Jonung, provides some historical background. Jonung argues that the history of Swedish economics is primarily the history of its professors. The logic behind this approach is the German Lehrstuhl tradition, which has been adopted in Sweden. ${ }^{17}$ Jonung first describes how the market for professors has developed, from David Davidson's single chair to almost forty chairs 


\section{Introduction and background studies}

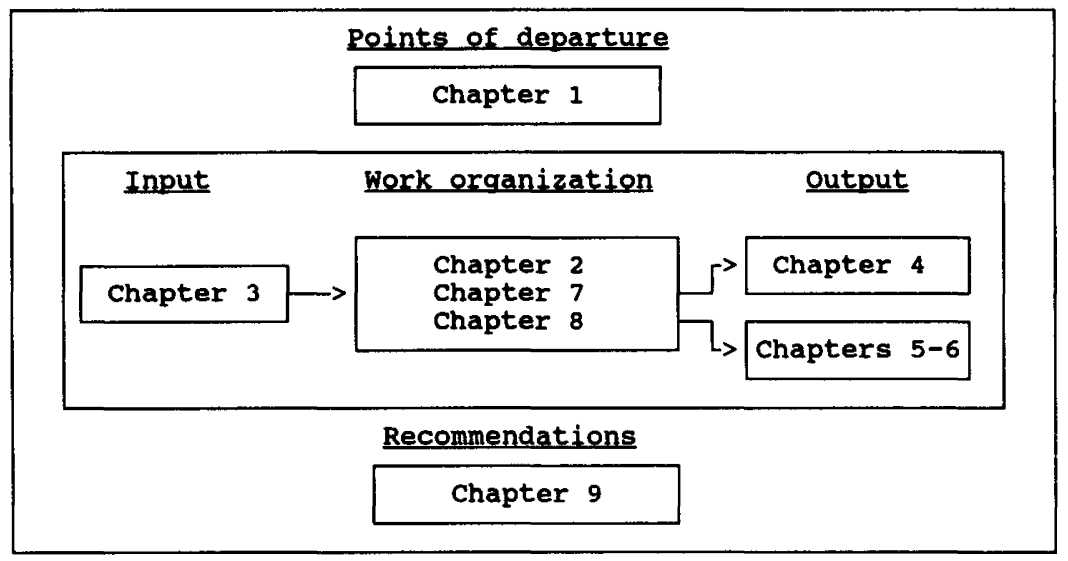

Figure 1.4 Composition of the book

in the early 1990s. In subsequent sections he describes the incentive structure that faces Swedish academic economists. The struggle for professorial competence is thus an important stepping-stone in the Swedish system. In the earlier period professors who had once passed the gatekeeper mechanism of the evaluation committees had only limited incentives to continue to produce scholarly work. Jonung's analysis suggests that their activities within their departments were dominated by efforts to hold back their doctoral students and colleagues. When he turns to their publications Jonung finds that early Swedish professors of economics were generally involved in the public debate, some even becoming Members of the Swedish Parliament or the Swedish Cabinet. Jonung's data, and the findings presented in later chapters, show that this role - which Stigler (1982) refers to as the preacher role - has become less important. Thus Swedish economists seem to be following an international trend described by Coats and Colander as follows:

Most modern economists are not preachers. They would rather see themselves and be seen as scientists, more interested in knowledge for its own sake than for its potential policy implications.

(Coats and Colander 1989: 2)

An important explanation of this development revealed by Jonung's analysis lies in the internationalization of scientific work, which has obviously had an impact on Swedish economics. 
In a second background study reported in Chapter 3 Peter Stenkula and Lars Engwall present an analysis of the input of resources into Swedish economics during the 1980s. First they describe the Swedish system of resource allocation, which is characterized by multiple sourcing. A basic source of funding consists of allocations from the Ministry of Education to the different universities. Another consists of research grants from various research-funding bodies. ${ }^{18}$ The analysis in Chapter 3 shows that total basic financing at 1989-90 prices oscillated round SEK 20 million up to 1986-7, subsequently increasing slightly to SEK 28.5 million in 1989-90. Despite this increase, economics' share of total social science funding has dropped from 8.1 per cent to 6.7 per cent. However, this decline appears to be an effect of the integration of certain external units into the universities rather than any systematic withdrawal of support from economics. In relation to GNP faculty grants have thus been fairly constant throughout the 1980s. A total of SEK 230 million at $1989-90$ prices was given to the institutions under study in the form of faculty grants. At the same time they received SEK 203 million in research grants applied for. Research grants from bodies supporting applied research have been particularly substantial. They thus accounted for about threefifths of all research grants to economics during the 1980s. All in all the analysis shows that IIES has received about one-fifth of the total resources provided to the universities and the Stockholm School of Economics, while HHS, Gothenburg, Lund and Stockholm have received a little more than one-seventh each, and SOFI, Umeå and Uppsala less than one-tenth each. A certain concentration of resources to the Stockholm area was observed.

In Chapter 4 the first of the chapters devoted to research output, Eskil Wadensjö discusses Swedish postgraduate education. He starts by describing the institutional framework, which was originally modelled on the prevalent model on the Continent and demanded extremely substantial theses. Following a reform in the late 1960 s an American Ph.D. type of model was adopted. However, Wadensjö's analysis shows that this change did not work as envisaged. Periods of study have tended to be well above the intended four years. Nor has the age of those passing the Ph.D. exam fallen compared to those studying under the old system. Many registered Ph.D. students also tend to drop out along the way. These findings are consistent with the results of analyses in other disciplines. ${ }^{19}$ They suggest that something needs to be done about Swedish postgraduate education.

In an analysis of the contents of the theses, Wadensjö found that these cover a wide range of subjects with a general pattern rather 


\section{Introduction and background studies}

similar to that disclosed for international publications by Swedish economists in Chapter 5 (see below). Similarly a certain specialization between the departments is demonstrated. Wadensjö is also able to show that the earnings vary considerably between different cohorts of economists holding Ph.D. degrees. Another established feature of the labour market is that due to the present age structure there will be few retirements before the first decade of the next century, when a large number of positions will suddenly become vacant. This will obviously be a very important factor to consider in recruiting a new generation of Swedish economists.

Chapter 5, written by Olle Persson, Peter Stern and Elving Gunnarsson, adopts a bibliometric approach, using what is perhaps the most controversial tool of evaluation. It once caused the British scientist Sir David Phillips to comment: 'We are certainly looking where the light is, but is the light shining where we need it?' (Phillips 1989: 215).$^{20}$ Others, such as Narin (1987), however, have pointed out that 'the results of bibliometric studies are seldom counter-intuitive: they usually agree with expert expectation'. In the present context it is also particularly important to stress that the bibliometric studies are only one of several approaches to the study of Swedish economics. ${ }^{21}$ The results presented in Chapter 5 are also consistent with those reported in other chapters in this volume. In Chapter 5 it is shown that Swedish economists tend increasingly to publish their research results in international journals, thus achieving the same world market share as their Swedish colleagues in physics, chemistry and engineering. In line with findings regarding other disciplines and from other countries, the distribution of publications is highly skewed. Swedish economists also publish in core economic journals about as much as their colleagues in other countries. They seem to have become particularly visible to the international audience in areas such as regional, urban and international economics. Other important fields have been general economics and labour economics. On the whole the study shows that Swedish economists are relatively well integrated into the international research community. ${ }^{22}$ Most of them would therefore agree with one of the key figures in David Lodge's novels, the American professor of Literature Morris Zapp, when he declares:

There are three things which have revolutionized academic life in the last twenty years [. . .]: jet travel, direct-dialling telephones and the Xerox machine. Scholars don't have to work in the same institution to interact, nowadays: they call each other up, or they 
meet at international conferences. [. . .] As long as you have access to a telephone, a Xerox machine, and a conference grant fund, you're OK, you're plugged into the only university that matters the global campus.

$$
\text { (Lodge 1985: 43-4) } \text { 23 }^{23}
$$

This internationalization of Swedish economics is also an important theme in the second part of the book, in which the three members of the international evaluation committee present their views on Swedish economics in the 1980 s, and make their recommendations. According to the evaluators the internationalization trend means that a third Swedish School, comparable in magnitude to the earlier two, is highly unlikely. Swedish economists should aim instead to make contributions to the expanding international literature. ${ }^{24}$ The group demonstrates this course of events in Chapter 6 in a survey of Swedish economics in the 1980s. They focus first on a number of applied areas in which Swedes have tended to specialize: labour economics, natural resources, interregional economics, international economics and public finance. In two later sections they turn to the more general fields of microeconomics, macroeconomics and monetary economics.

Although the group has been able to indicate a number of important contributions by Swedish economists during the 1980s, its members have also identified some problems in the fields of economics research in Sweden. To a large extent they see these as being an effect of institutional conditions, and in the two following chapters they therefore turn their attention to these conditions. Chapter 7 deals with the general organization of research, while Chapter 8 focuses on postgraduate education. In the first of these chapters the evaluators comment on the distribution of resources and the limited scale of the different departments. They find this particularly worrying, since the Swedish system is also characterized by a high degree of inbreeding and by low mobility between departments. ${ }^{25}$ Another thing which the evaluators noted was the lack of obvious career paths in research in either the universities or the research institutes. They also stress the desirability in many instances of raising the level of research ambitions.

In Chapter 8 the international evaluation group presents a similar survey of Swedish postgraduate education. They find limitations with regard to the scale and the level of productivity highly alarming. They therefore argue for more structured doctoral programmes and greater incentives for Ph.D. candidates to complete their studies, and to do so 


\section{Introduction and background studies}

more quickly. Again they are concerned about the low mobility between universities and the lack of clear career paths.

After giving their views on Swedish economics in Chapters 6-8, the three members of the international evaluation committee conclude in Chapter 9 by making their recommendations for action. First they discuss certain aspects of the system which they have found significant: the earlier record of excellence, internationalization, resources, scale, incentives, tradition and career paths. As regards the organization of research, they suggest the creation of national networks of economists working in similar areas, improvements in the links between university departments and research institutes, a reform of the career path system, and a stronger focus on basic research. As regards postgraduate education the evaluators call for a concentration of resources, a core curriculum for doctoral students, a national system of intensive field courses, fellowships for study overseas and at home and, last but

not least, a change in direction towards theses in the shape of collections of articles. To summarize: the evaluation group strongly stresses the need for a radical change in three vital components of the system under study: cooperation, career paths and postgraduate education.

\section{EVALUATING THE EVALUATION}

Just as Swedish economics has been evaluated in the present project, the evaluation project itself should also be subjected to scrutiny. In terms of the values referred to on pages 5-8 we can now ask ourselves: has the evaluation been responsive and objective? Is it trustworthy and generalizable? Naturally it is not the concern of the contributors to this volume to answer such questions. That is a task for the various stakeholders. ${ }^{26}$ Nevertheless, some comments can perhaps be made. There does seem reason to believe that the very decision to undertake the project has had an effect on Swedish economists, in that more than before they have started to compare their work and their working conditions with those of others. And this has been reinforced in the course of collecting the material and making the site visits. ${ }^{27}$ However, the main effects can be expected to appear after completion of the present report. Even if it has no effect at all on the resource-granting bodies, it will influence views on Swedish economics. ${ }^{28}$ Scholars in the fields of sociology and the philosophy of science (cf. e.g. Kuhn 1962 and Hull 1988) have stressed the importance of noting the human characteristics of scientists, their vested interests and their priorities. Thus researchers participate in social 
interactions, during which they tend to utilize available information to their own advantage. Nor is this limited to the social sciences and the humanities. As Mitroff (1974) has vividly illustrated in a study of eminent geologists examining rock samples brought back from the Apollo moon mission, researchers in 'the hard sciences' also reveal these tendencies. And McCloskey (1986: 32-4) even argues that 'mathematics, [. . .] the queen herself' is rhetorical in character. ${ }^{29}$ In the terminology of the sociologists Berger and Luckmann (1966), scientists create reality together. According to this view we have to accept that even apparently objective data has been 'created' under certain assumptions or theories. ${ }^{30}$ It is then likely to be appreciated by anyone finding positive support in it, whereas others are likely to seek supplementary evidence leading to their own particular favoured conclusion. ${ }^{31}$ In business this has been pertinently illustrated by Hägg (1979) in an analysis of the ex post evaluation of investments. Hägg shows first that although investment calculations before an investment are compulsory, evaluations afterwards are rarer. Even more interesting in our present context is the fact that, when evaluations were undertaken, explanations were always given of negative deviations from the original calculations. Along the same lines Pedersen (1977) suggests that it is quite rational for agency heads to resist changes proposed by evaluators. And as regards economists, Malinvaud (1985: 170) has pointed out that 'protagonists will often find apparently good reasons for explaining why their own theory did not work well in some particular cases'.

All this brings us to the eternal argument in research evaluation about interpretation. Should previously successful areas or institutions be rewarded by the allocation of yet more resources, or should weak units be supported to encourage improvement? The answers to these questions are not self-evident, and will ultimately depend on the ability of different types of economists to argue their own case before their academic colleagues inside and outside the profession and before the resource-allocating bodies. ${ }^{32}$ In this discourse, or the rhetoric of the economists as McCloskey (1983, 1986 and 1990) call it, it can be hoped that the present evaluation will constitute a relatively balanced input. ${ }^{33}$ According to Hull (1988) it will then become part of a natural selection process characterized by replication, interaction and evolution. As regards the future development of this kind of competitive process, which is likely to assume an increasingly international character, we can only speculate today. Several distinguished economists have recently done just this, when they were asked to say something about the next 100 years in economics. It seems fairly safe, 


\section{Introduction and background studies}

however, to agree with Milton Friedman's answer to this question in an article entitled 'New Wine in Old Bottles', namely that while the problems treated by economists tend to be eternal, the ways of handling them may change. ${ }^{34}$ In another answer Edmond Malinvaud (1991) takes up this last point and suggests that methodological development is likely to imply growing cooperation between economists and scholars from other disciplines. Such an eventuality is not without complications, however. As McCloskey (1990: 162) has pointed out, relations between economists and adjacent disciplines are not always friendly. He even maintains that 'the neighbors of economics hate its arrogance, as the neighbors of physics do ${ }^{35}$ Be that as it may, it is nonetheless extremely important to promote the dynamics of the system, i.e. to provide good opportunities for the development of the discipline. And here, as Pasinetti (1985: 186) has pointed out, it is desirable that 'citation clubs' be avoided and that the heavy responsibilities of prize awarding and research grants committees be kept in mind.

But the message of the project is not addressed solely to economists. The conclusions arrived at and the recommendations made certainly have a much wider bearing than this would imply. They constitute a plea for reforming the institutional conditions, not only in economics but also in other disciplines for which the Swedish Council for Research in the Humanities and the Social Sciences assumes a responsibility. Despite apparent differences in coherence and publication traditions between the various academic disciplines (cf. e.g. Lodahl and Gordon 1972), the conclusions and recommendations presented here may even have general implications for yet other disciplines and even for the organization of research in other small countries. The question remains, however, as to whether the most important part of the exercise may not have been the process rather than the product. If this is so, then the impact outside economics will be limited at least in the short run. In a longer perspective, however, if Swedish economists and their resource-providers take the report on board, some of its ideas are likely to spread. Institutional theories of organization have shown how the power of example can trigger the imitation of social designs in new fields (DiMaggio and Powell 1983). In the terminology introduced by Argyris and Schön (1978), we will then have not only single loop but also double loop learning, i.e. true learning by way of adaptations outside the existing norms. 


\title{
2 Economics the Swedish way 1889-1989
}

\author{
Lars Jonung assisted by Elving Gunnarsson
}

\section{INTRODUCTION ${ }^{1}$}

As Johnson (1973, 1977) has pointed out, there are 'national styles' in economics research and teaching. In describing the development of the Swedish style of economics, I have taken the academic system in the United States as my point of reference, ${ }^{2}$ and David Davidson's appointment to the chair in Uppsala in 1889 as the starting date. The account therefore covers one century, although the founding period actually occurred in the first decade of the 1900s when Knut Wicksell was appointed to Lund University, Gustav Cassel to Stockholm College and Eli Heckscher to the Stockholm School of Economics. Economics in Sweden has a much longer history than this, however. Chairs were established in 1741 and 1750 at Uppsala and Lund, making Sweden the country with the second oldest academic economics tradition in the world. The first chairs had been created earlier in Germany. (See Appendix B for a list of all Swedish professors of economics over the past 250 years.)

The history of Swedish economics is basically the history of its professors, or more precisely the history of the seventy to eighty people who have held chairs in economics and economic history over the past hundred years, because the professor has occupied a dominant position in the academic system. ${ }^{3}$ For this reason the account concentrates on the market for and the performance (behaviour) of professors, emphasizing various aspects which appear specific to economics in Sweden as compared to the United States. A chronological approach is adopted.

First, the extent of the university market for professors is described. By far the most striking feature of Swedish economics is that it succeeded in making a number of important contributions between 1890 and 1940, in spite of a narrow academic base. Second, the 


\section{Introduction and background studies}

incentive structure of the academic system is considered. For a long time this system was designed in a way that was essentially detrimental to scientific progress. Third, the extramural activities of Swedish professors of economics are explored, since these have played an important role in Swedish public life. I will look at the part the professors have played as policy advisers and as authors of official government reports, as well as their journalistic activities and their participation in the public debate - in a tradition that started with Wicksell and Cassel. ${ }^{4}$ Fifth, the originality of Swedish economics is discussed, in particular the influence of American economics on Swedish research. Finally, three institutions of economics - the Stockholm School of Economics, the Department of Economics at Lund, and the Institute of International Economic Studies at Stockholm - are briefly considered in Appendix C, because all these institutions have been an important source of influence on the development of Swedish economics.

\section{THE DEVELOPMENT OF THE MARKET FOR PROFESSORS}

One hundred years ago David Davidson at Uppsala was the sole Swedish professor of economics, as the subject is understood today. $\mathrm{He}$ was appointed to his chair at Uppsala in 1889. Although there was also a chair in law and economics at Lund, this was not held by an economist. The expansion of the field of economics started during the first decade of the present century: Knut Wicksell was given a temporary chair at Lund in 1901, and a permanent one in 1904; Gustaf Steffen was appointed to a new chair in economics and sociology in 1903 at the College of Gothenburg (Göteborgs högskola), later Gothenburg University; ${ }^{5}$ Gustav Cassel obtained the new chair in Economics and Public Finance in 1904 at the College of Stockholm, later Stockholm University; and Eli Heckscher the first chair purely for economics in 1909 at the recently founded private institution, the Stockholm School of Economics. ${ }^{6}$ (See table 2.1 and figure 2.1.) There was one professor in the subject of economics at each university at that time. Modern departments started to develop much later, in the 1950s.

Davidson, Wicksell, Cassel and Heckscher can be regarded as the founding fathers of Swedish economics. They established economics in Sweden as an academic discipline of high standing and considerable international fame. ' In 1899 Davidson founded Ekonomisk Tidskrift, the first professional journal of economics in Sweden. He was editor for forty years, publishing a great many articles and commentaries 
Table 2.1 Occupants of chairs in economics 1889-1989

\begin{tabular}{|c|c|}
\hline Uppsala & Lund \\
\hline $\begin{array}{l}\text { Faculty of Law } \\
\text { 1889-19 David Davidson } \\
\text { 1921-42 Fritz Brock } \\
\text { 1942-58 Erik Lindahl } \\
\text { 1964-9 Tord Palander } \\
\text { 1969-87 Göran Ohlin }\end{array}$ & $\begin{array}{l}\text { Faculty of Law } \\
\text { 1901-16 Knut Wicksell } \\
\text { 1919-39 Emil Sommarin } \\
\text { 1939-42 Erik Lindahl } \\
\text { 1943-7 Johan Åkerman }{ }^{\mathrm{b}} \\
\text { 1948-74 Carsten Welinder } \\
\text { 1970-87 Bengt Höglund } \\
\text { 1988- Ingemar Hansson }\end{array}$ \\
\hline $\begin{array}{l}\text { Faculty of Social Sciences } \\
\text { 1948-64 } \\
\text { 1965-85 }\end{array}$ & $\begin{array}{l}\text { Faculty of Social Sciences } \\
\text { 1947-61 Johan Åkerman } \\
\text { 1961-8 Guy Arvidson } \\
\text { 1968-92 Björn Thalberg } \\
\text { 1971- Ingemar Ståhl } \\
\\
\text { International Economics } \\
\text { 1965-77 Torsten Gårdlund } \\
\text { 1977- Bo Södersten }\end{array}$ \\
\hline \multicolumn{2}{|c|}{ Gothenburg } \\
\hline 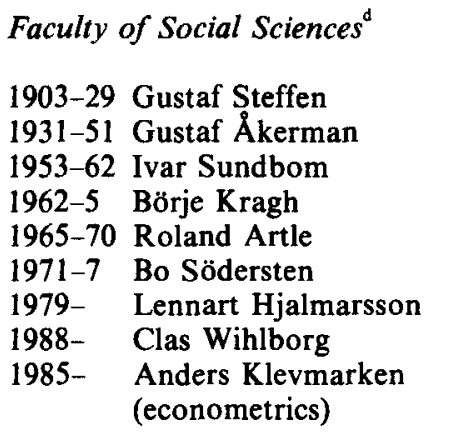 & $\begin{array}{l}\text { School of Economics and } \\
\text { Business Administration } \\
\text { 1923-32 Gunnar Silverstolpe } \\
\text { 1932-9 Erik Lindahl } \\
\text { 1941-8 Tord Palander } \\
\text { 1949-53 Ivar Sundbom } \\
\text { 1955-78 Harald Dickson } \\
\text { 1978- Johan Lybeck }\end{array}$ \\
\hline Stockholm University & Stockholm School of Economics \\
\hline $\begin{array}{l}\text { Faculty of Law } \\
\text { 1904-33 Gustav Cassel } \\
\text { 1934-50 Gunnar Myrdal } \\
\text { 1951-67 Ingvar Svennilson } \\
\text { 1969- Lars Werin } \\
\text { Faculty of Social Sciences } \\
\text { 1921-49 Gösta Bagge } \\
\text { 1949-51 Kjeld Philip }\end{array}$ & $\begin{array}{l}\text { 1. 1909-29 Eli Heckscher } \\
\text { 1929-65 Bertil Ohlin } \\
\text { 1965-74 Erik Lundberg } \\
\text { 2. 1917-46 Sven Brisman } \\
\text { 1947-63 Torsten Gårdlund } \\
\text { 1964-71 Assar Lindbeck } \\
\text { 1972- Karl Jungenfelt }\end{array}$ \\
\hline
\end{tabular}




\section{Introduction and background studies}

Table 2.1 Continued

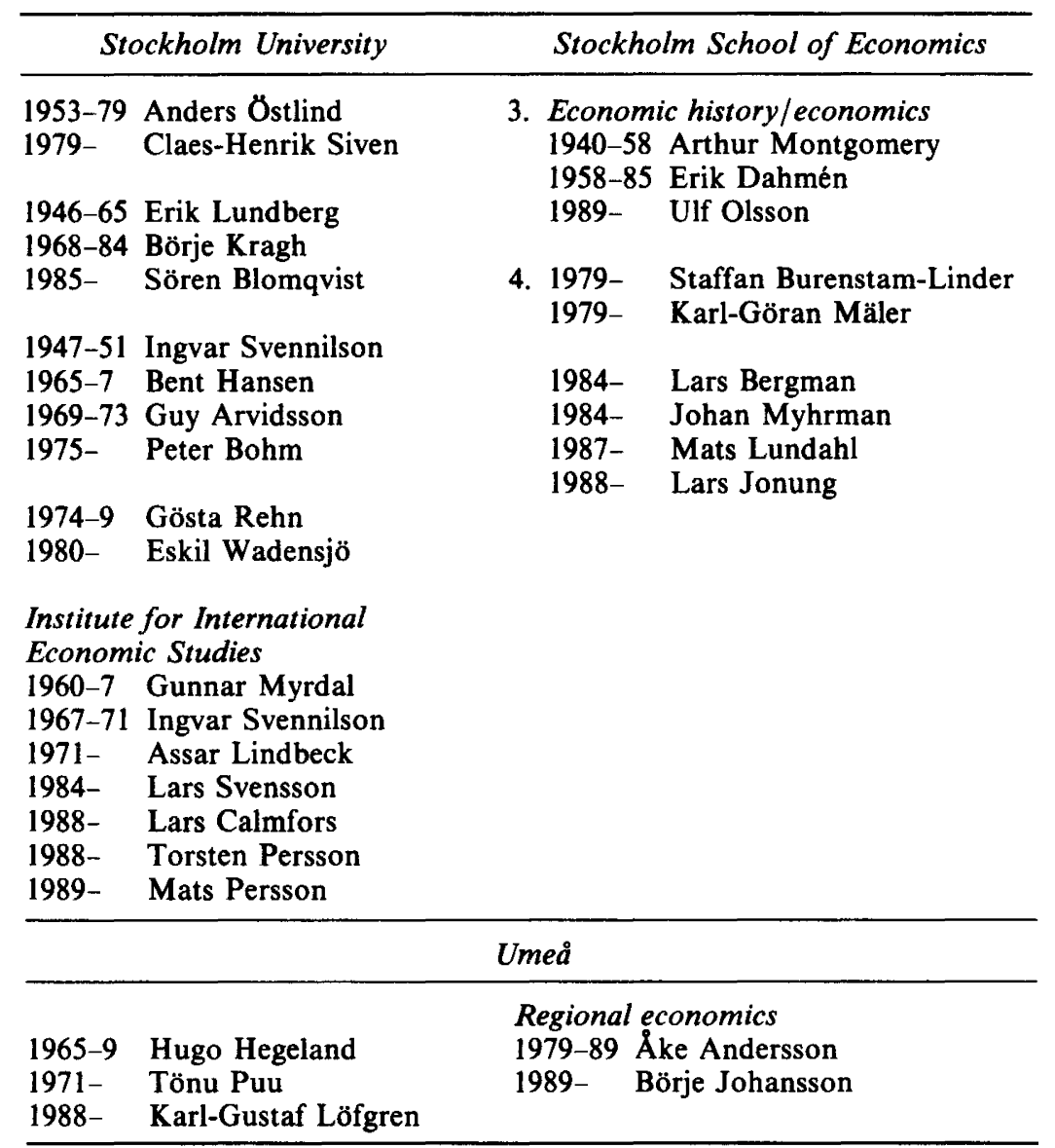

Notes: ${ }^{2}$ Faculty of Philosophy prior to 1965.

bohan Åkerman was professor in the faculty of law and the faculty of philosophy 1943-7.

"There was no professor of economics in the law faculty between 1947 and 1970 , but a chair in public finance and fiscal law was occupied by Carsten Welinder 1948-74.

- Faculty of Philosophy prior to 1965.

- Faculty of Social Sciences from 1972.

Comment: The table does not include professors with doctoral degrees in economics who were appointed to chairs outside the 'ordinary' departments of economics. This applies to Karl-Gustav Lögren, professor in forest economics at the College of Forestry in Umeå 1979-88, Sören Wibe joining Karl-Gustav Löfgren, and Bengt Jönsson, professor in health economics at Linköping 1981-91, and Karl Lidgren, professor in environmental sciences at Lund 1985. Nor does the table include Herman Wold, professor of statistics at Uppsala, who made important contributions to the field of economics. 


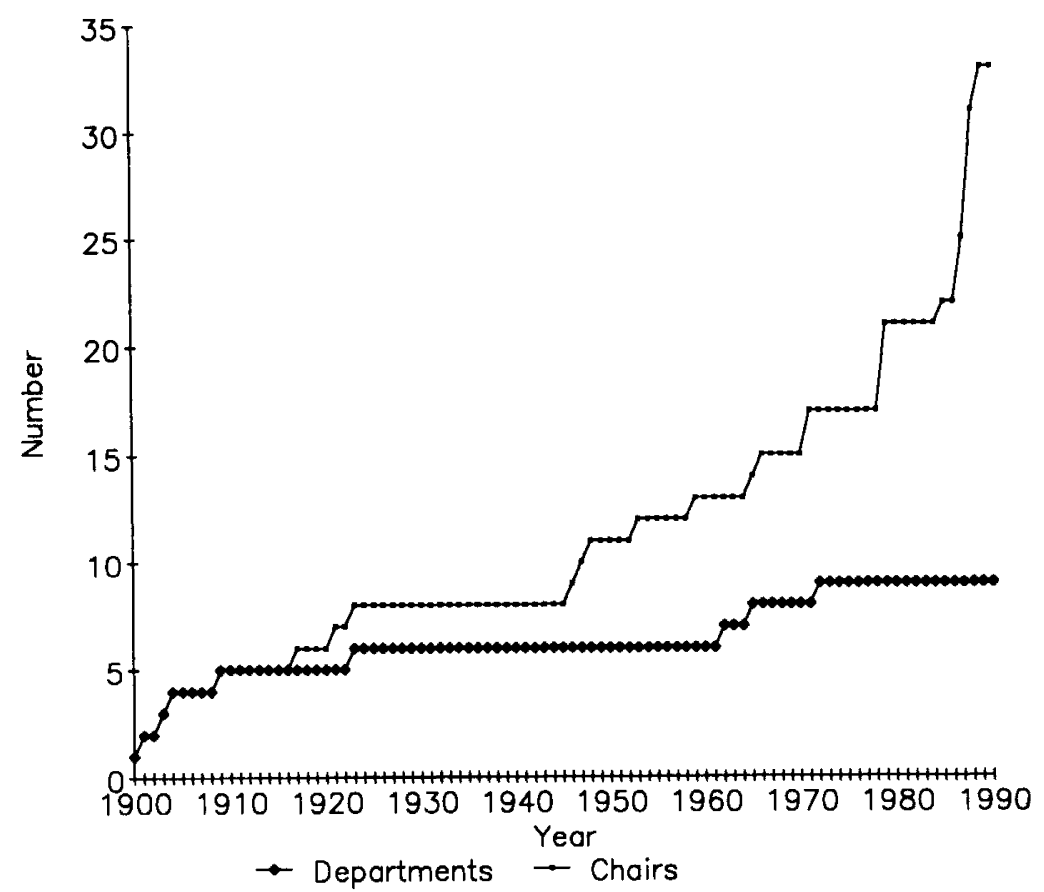

Figure 2.1 The number of chairs and departments of economics in Sweden 1889-1989

himself and encouraging his colleagues to contribute as well. ${ }^{8}$ Within a fairly short period in the 1890 s Wicksell published three epoch-making books: Über Wert, Kapital, und Rente (1893), Finanztheoretische Untersuchungen (1896) and Geldzins und Güterpreise (1896); he later summarized his views in the two volumes of his Lectures. Cassel was the first Swedish economist to establish himself deliberately outside Sweden. He was probably the best-known economist internationally prior to the rise of Keynes. His address to the American Congress in 1928 marks the peak of his influence. And, lastly, Heckscher gained prominence as an economic historian with his study of the mercantilist system.

Besides making important advances in the field, the founding fathers were also highly visible in the Swedish public debate, in particular Wicksell, Cassel and Heckscher. They made their subject familiar to the public and the political community, and exerted a considerable influence on Swedish economic policy. As discussed 


\section{Introduction and background studies}

below, they set an example and inspired later generations of economists by creating a strong public platform for economists.

It is remarkable that this group of economists succeeded in emerging at the turn of the century and launching their field so successfully. In this context the role of the Loren Foundation should be stressed. This foundation gave generous travel grants to Knut Wicksell and Gustav Cassel, making it possible for them to study abroad for long periods of time. ${ }^{9}$ Moreover, Heckscher managed to obtain a chair in economics on the recommendation of Cassel, although he was originally a historian, holding a licentiate in that subject. But, once a professor, Heckscher turned to the study of economics with great enthusiasm, specializing in the British economics tradition.

The works of the founding fathers inspired a second brilliant generation that established itself during the 1920s and 1930s. Later to be known as the Stockholm School, it included Dag Hammarskjöld, Alf Johansson, Karin Kock, Erik Lindahl, Erik Lundberg, Gunnar Myrdal, Bertil Ohlin and Ingvar Svennilson. They extended the heritage of Wicksell and Cassel in a number of ways. In his thesis in 1919 Lindahl developed Wicksell's ideas about public finance and taxation. In his doctoral thesis in 1924 Ohlin extended Cassel's equilibrium system to the theory of international trade, and in his thesis in 1927 Myrdal introduced uncertainty and risk into Cassel's system. In the 1930s Wicksell's cumulative process became a source of inspiration when, influenced by the depression, this group of economists turned to the study of unemployment and cyclical fluctuations. Hammarskjöld and Lundberg studied dynamic processes in their theses in 1933 and 1937 respectively, while in 1938 Svennilson considered the problems of multi-period planning in firms under uncertainty.

The Stockholm School marks the heyday of Swedish economics. How could this outpouring of work develop from so small an academic base - fewer than ten chairs in the 1930s? Moreover, several of these were held by economists not active in research: Emil Sommarin occupied the chair after Wicksell at Lund (1919-39), Gustaf Åkerman was at Gothenburg (1931-53), and Fritz Brock at Uppsala (1921-42), blocking possible new entrants to these chairs throughout the interwar period. ${ }^{10}$ Part of the answer is that the new generation was able to find financial support and intellectual inspiration outside the university system, primarily from two sources: first, the National Income project led by Gösta Bagge and supported by Rockefeller money during the period 1925-40, and second, the Unemployment Committee active in the period 1927-33." 
The Swedish university market did not expand in the 1930s to absorb the influx of economists who had obtained their doctoral degrees (see table 2.1 and figure 2.1). This contributed to the decline of the Stockholm School in the 1940s. There were simply too few members of the school with permanent positions in the university system. Moreover, those holding chairs were busy with other activities besides research and teaching. Very few of them managed to obtain chairs before the Second World War: Bertil Ohlin became first professor in Copenhagen in 1924 and Gunnar Myrdal obtained a position in Geneva. Ohlin returned to Sweden in 1929, accepting Heckscher's vacant chair when a research professorship was established in economic history for Heckscher to console him for not becoming president of the Stockholm School of Economics. Myrdal succeeded Cassel in 1934. Erik Lindahl, the oldest of them all, had considerable problems. He competed with Ohlin for Copenhagen and with Gustav Åkerman for Gothenburg, but did not get a chair until 1932 - first at Gothenburg, later at Lund and finally at Uppsala. $\mathrm{He}$ was classified as the 'permanent docent' and it is said that in the 1920s Heckscher urged Lindahl to become a practising lawyer since he had a degree from the faculty of Law at Lund.

Several economists abandoned the academic world. Dag Hammarskjöld pursued a distinguished career in the Riksbank (Sweden's central bank) and the Ministry of Finance and later at the United Nations; Karin Kock turned to the civil service after being professor; Alf Johanson did the same, and he became the chief ideologue responsible for the Swedish housing programme. Erik Lundberg became the first head of the National Institute of Economic Research (Konjunkturinstitutet) in 1937, later combining this position with a chair at Stockholm University from 1946. Finally he became professor at the Stockholm School of Economics. Ingvar Svennilson went first to the National Institute of Economic Research and later accepted a position at the Industrial Institute for Economic and Social Research (Industrins utredningsinstitut), before becoming professor in 1947. During the Second World War economists were drawn into public administration and became engaged in practical matters. From this point on, theory development in the Stockholm tradition virtually ceased. $^{12}$

From the end of the 1940s onwards the number of chairs grew. By 1950 there were eleven chairs in economics altogether, including Arthur Montgomery's chair in economics and economic history at the Stockholm School of Economics. The number was the same in 1960 but had risen to fourteen by 1970 , to seventeen by 1980 and about 


\section{Introduction and background studies}

Table 2.2 The establishment of departments with professors of economics 1889-1989

\begin{tabular}{lc}
\hline Institution & Year \\
\hline Uppsala & 1889 \\
Lund & 1901 \\
Göteborgs högskola/ Gothenburg University & 1903 \\
Stockholms högskola/Stockholm University & 1904 \\
Stockholm School of Economics & 1909 \\
Gothenburg School of Economics & 1923 \\
Stockholm University, IIES & 1962 \\
Umeå & 1965 \\
Stockholm University, SOFI & 1972 \\
\hline
\end{tabular}

thirty by 1989 . The second half of the 1980 s witnessed a sharp rise, primarily in the Stockholm region (see figure 2.1).

There are now six large departments of economics with their own chairs: at Lund, Gothenburg, Uppsala, Umeå, at the Stockholm School of Economics and at Stockholm University (table 2.2). Stockholm University holds a dominant position as regards the number of chairs; including the Institute for International Economic Studies and the Swedish Institute for Social Research (SOFI) there are about twelve professors there.

In the 1950s and 1960s economists were primarily involved in problems associated with the growth of the public sector. Some of the areas in which those who obtained chairs in economics during the period 1950-75 were specializing included housing policy (Assar Lindbeck, Ingemar Ståhl, Ragnar Bentzel, Guy Arvidson); education (Ingvar Svennilson, Ståhl); defence (Bengt-Christer Ysander, Ståhl); monetary policy and stabilization issues (Arvidson, Bent Hansen, Lindbeck); economic growth and structural change (Karl Jungenfelt, Svennilson, Erik Dahmén); welfare economics and environmental economics (Peter Bohm, Karl-Göran Mäler); and regional economics (Åke Andersson).

In the 1970 s a generation emerged with a focus on macroeconomic issues, labour and money, greatly inspired by American research. This generation, including among others, Lars Calmfors, Bertil Holmlund, Lars Jonung, Johan Lybeck, Karl-Gustaf Löfgren, Johan Myhrman, Claes-Henric Siven and Eskil Wadensjö, generally combined theory with empirical testing based on Swedish data, sometimes trying to extend the prevailing theories to cover specific Swedish institutional particularities. In the 1980 s a new generation of professors emerged 
with a stronger mathematical orientation than previously, including Lars E. O. Svensson, Mats Persson, Torsten Persson, and Ingemar Hansson. This generation has been able to establish itself in the profession more quickly than any previous one, particularly at the Institute of International Economic Studies (IIES). This institute has displayed remarkable growth in the number of its chairs during the 1980s: its four or five new chairs in the 1980s alone correspond to the number in a major department outside Stockholm (table 2.1).

Very few new chairs exclusively in economics were established during the 1980s. Instead the field was growing as a result of diversification, i.e. the establishment of chairs in specialized subfields of economics such as energy economics (Lars Bergman), international economics (Mats Lundahl, Staffan Burenstam Linder, Lars E. O. Svensson, Torsten Persson and Lars Calmfors) and financial economics (Clas Wihlborg and Peter Englund). It was easier to obtain funding from government or private sources for such specific fields.

The evolution of Swedish economics as described here is summarized in table 2.3, which illustrates the fairly topical nature of Swedish economics. ${ }^{13}$ The first generation of economists was primarily interested in capital theory, monetary issues and problems of taxation. Following the depression of the 1930s the profession gradually moved towards the analysis of business fluctuations. Since then the problems of the mixed economy have been high on the research agenda. From the 1970s onwards research methods and theory, and increasingly even the agenda of problems to be studied, have been imported from abroad - primarily from the leading American universities. From the 1960s and 1970s it is difficult to single out any really innovative Swedish contributions to economics. The EFOmodel is sometimes cited in this context, but this model is basically a Swedish version of the Norwegian Aukrust-model. ${ }^{14}$ But two creative contributions can be identified from the 1980s: the study of the small open economy and of labour market issues. But Swedish economists appear less independent scientifically today than they were in the interwar period. ${ }^{13}$

In Sweden the study of economic history has its roots in economics. In 1929 Heckscher was given a personal chair in economic history. This was the start of economic history as a separate subject in the Swedish university system. Today there are chairs in economic history at all the major universities. This pattern can be compared with the United States, where economic history is included in the departments of economics. The separation of the two in Sweden has given the subject of economic history a strong position in both research and 


\section{Introduction and background studies}

teaching. One drawback of this arrangement is that the development of theory is left entirely to economists. The economic historians end up borrowing from economics - if they employ economic theory at all with little or no feedback to economics. And over the years there has unfortunately been little interaction between economics and economic history.

In spite of the work of Herman Wold and his followers in Uppsala, and the availability of data on Swedish economic developments, econometrics has not played the same role in economic research and graduate training in Sweden as it has in many other countries. The main reason is that econometrics was primarily studied in departments of statistics, which inhibited fruitful interaction with economists. Econometrics was not required for a Swedish Ph.D. degree until recently. The first chair in econometrics in the state university system was established in 1985 by HSFR. Before that there was a chair in economic statistics at the Stockholm School of Economics. ${ }^{16}$

Compared to the other social sciences economics is a fairly big subject in Sweden. Business administration, a late entrant into the academic field, is the main challenger when it comes to size. But by international standards the total number of chairs in economics is quite small. Sweden has currently between thirty and forty professors of economics, including econometrics and economic history. True, there are a number of intermediate positions such as lecturers, docents and researchers in the Swedish system, including some at research institutes outside the universities. These are occupied by economists with qualifications similar to those of assistant, associate or even full professors in the United States. If these are included, Sweden could probably claim about $140-50$ professors of economics. This group is scattered over many departments and research institutes, so that no department can match the breadth and quality of a major American department of economics.

\section{BECOMING A PROFESSOR}

The qualification for a professorship in the Swedish university system used to be to have written and successfully defended a doctoral thesis; this can be compared to the American system in which course work and qualifying exams are important hurdles. As a rule the thesis was the main work, the tour de force, of the aspiring Swedish scholar. Writing it was a task generally left to the individual students working alone, with little if any guidance from their supervisors. The opponent, often a docent (an assistant professor without tenure), used to have a 
Table 2.3 The four phases of economics in Sweden 1889-1989: a stylized overview

Phase I: The founding fathers (about 1889-1926).

The marginalist revolution cum the quantity theory of money. General equilibrium economics, capital theory and public finance. Monetary economics influenced by the pre-1914 gold standard and monetary events during the First World War.

David Davidson, Knut Wicksell, Gustav Cassel, Eli Heckscher.

Phase II: The Stockholm School (about 1927-50)

a) The (early) Stockholm School of the 1920s. Value and monetary theory in the Cassel-Walras tradition. Equilibrium economics extended to public finance, international trade and dynamic problems.

Bertil Ohlin, Gunnar Myrdal, Erik Lindahl.

b) The Stockholm School of the 1930s. The development of disequilibrium and sequential approaches inspired by inter-war unemployment and the depression of the 1930s. Work in the Committee of Unemployment 1927-35. Studies of economic processes and adjustments.

Erik Lundberg, Erik Lindahl, Karin Kock, Alf Johansson, Bertil Ohlin, Gunnar Myrdal and Ingvar Svennilson.

c) The (late) Stockholm School of the period after the Second World War. The use of formal models.

Bert Hansen.

Phase III: Economics as a science applied to the welfare state (about 1950-75). Empirical macro- and microeconomics applied to the expanding public sector, bias towards public planning and proposals of government intervention inspired by Keynesianism and Pigovianism. Government long-term plans, studies of housing policies, schooling, defence, credit market controls, investment funds, public investments, cost-benefit analysis, industrial policy, and pension systems.

Ingvar Svennilson, Bent Hansen, Guy Arvidsson, Assar Lindbeck, Ingemar Ståhl, Bengt-Christer Ysander, Peter Bohm, Lars Werin, Börje Kragh and Karl Jungenfelt.

Phase IV: Economics the American way. The 'technical' revolution and diversification (1975-89).

a) Macroeconomics and labour economics, generally with empirical application to the Swedish experience.

Johan Myhrman, Johan Lybeck, Lars Calmfors, Lars Jonung, Claes-Henric Siven, Karl Gustav Löfgren, Bertil Holmlund and Eskil Wadensjö.

b) Economics of the 1980s.

Lars E. O. Svensson, Mats Persson, Ingemar Hansson and Torsten Persson. 


\section{Introduction and background studies}

Table 2.3 Continued

c) Diversification into new fields. Environmental economics (Karl-Göran Mäler, Lars Bergman), health economics (Bengt Jönsson, Björn Lindgren), finance (Clas Wihlborg, Peter Englund), regional economics ( $\mathrm{ke}$ Andersson).

Institutional undercurrent: Gustav Steffen, Gösta Bagge, Johan Åkerman, Gunnar Myrdal, Erik Dahmén, Ingemar Ståhl and Johan Myhrman.

Note: The table covers only economists with professorial chairs. It is intended to give an idea of the main lines of research activities, not to cover all forms of economic research over the past 100 years. Thus it is not all-embracing. A number of professors have been left out because it was difficult to classify their work under suitable 'headings'. Their exclusion does not signify a downgrading of their work. Many economists have been active in several fields of research. Here they have generally been classified according to the subject of their dissertations.

strong incentive for criticizing the thesis, as the candidate was likely to be a future rival for a chair in the small market for new professorships. If the thesis was given a high mark, its author could apply for the title of docent with a high chance of being able to remain at the university and eventually to obtain a chair. If the thesis got a low mark, life outside the university was waiting, commonly offering a teaching position at a gymnasium (upper secondary school or sixth-form college), particularly for doctors in the humanities. The history of Swedish university life is littered with personal tragedies and crushed expectations in connection with doctoral theses. The field of economics has also had its share of these, although probably fewer than in most of the other social sciences or in the humanities.

Many economists, such as Gösta Bagge, Eli Heckscher, Bertil Ohlin and Gunnar Myrdal became professors primarily on a basis of their theses. ${ }^{17}$ However, in recent decades this pattern has changed as a result of several major reforms in the educational system, reflecting American influence. The thesis and its defence are no longer so important. The number of articles the candidate has published, preferably in English and in refereed journals, is given great weight. Publication in international journals is in fact a recent phenomenon of the 1970s and 1980s. Several professors who obtained chairs before 1980 hardly published anything in foreign refereed journals, either before or after their appointments.

After a successful doctoral thesis, the next step for the professorial candidate was to wait for an opening, while continuing to produce additional scientific work to acquire 'professorial competence'. The 
position of docent usually provided the best opportunity for doing scientific work. As a rule the post was obtained at the same university which had granted the Ph.D. In the Swedish system, in contrast to the United States, new doctors did not generally - and still do not - leave the department where they obtained their doctorates. On the contrary, the degree is commonly seen as a guarantee for staying on and winning greater job security, usually by becoming a university lecturer - a position which is nowadays a common first step in an academic career.

An opening occurs either as a result of the retirement of a professor or the establishment of a new chair. ${ }^{18}$ Swedish and foreign candidates are both eligible to apply. A committee usually consisting of three senior professors - generally of Swedes or Scandinavians - is appointed on a basis of suggestions from all the economics departments in the country. The committee scrutinizes the accomplishments of the candidates, in particular their publications. Each member or sometimes a group of members produces a comprehensive written evaluation of the accomplishments of the candidates and places them, or a selection of them, in ranking order. These evaluation committee reports play an extremely important part in the selection process. They are generally binding for the final appointment, which until 1974 was made by the King-in-Council but is now made by the Government on the recommendation of the university where the vacancy exists.

Applicants dissatisfied with the verdict can lodge a complaint, an opportunity which is sometimes taken up. Some of the most spirited academic exchanges have occurred in connection with clashes about evaluation committee reports. The reason is simple. The future of the candidates is at stake. The number of positions is limited. In academic subjects with only a couple of chairs in the whole of Sweden, the alternatives are to remain a non-professor for the rest of your life, or to emigrate.

The Swedish system of selecting professors is based on a comparison of the applicants, regardless of their particular fields and the existing composition of the professorial staff of the department concerned. The evaluation committee is thus forced to establish a ranking order among applicants with widely differing backgrounds. For example, an economist with a background in international trade has to be compared with a health economist, a specialist in game theory with an economic historian and so on. As very few committee members, if any, master all the relevant fields, the system tends to encourage diverging opinions among the members of the evaluation committee, all of whom have reasons for promoting their own field of specialization. 


\section{Introduction and background studies}

The American system is based instead on a ranking within the candidate's field of specialization, not across all the fields commanded by those applying for a post. When American university economists are being considered for promotion, each one is ranked against other economists in their own field and of roughly the same age. The yardstick is thus established professional output, and is more consistent than the various yardsticks constructed and inconsistently applied in the Swedish system.

The Swedish evaluation reports belong to the public records, which is not the case in the United States. In a field like political science, the reports are even regularly published in the journal of the profession Statsvetenskaplig tidskrift. The verdict of the evaluation tends to follow candidates until the next time they apply. Thus, it is important to get a good start. Application for a chair provides the only occasion on which the academic production of an economist is seriously evaluated. The evaluation represents a peer review, setting standards. The evaluations also provide important information to the profession about the scientific activities of its members.

Unlike the Swedish case, the American system works in confidence; the candidates being considered by a department are often evaluated without their knowledge and by anonymous referees. The judges' reports are not made public and the candidate has no opportunity to defend himself - but in the vast academic market they will have second and third chances if they do not obtain tenure.

In principle the Swedish system is based on open competition, with the majority of the referees and often all of them being chosen from outside the university that has announced a vacancy. However, in practice the local candidates do run on the inside track. Departments try to promote their local candidates in a market characterized by powerful local influence on the selection process and little mobility between universities. Nonetheless there is a flow of professors in economics between the Swedish universities. In the period 1970-88, Lund was the main exporter to Stockholm, Stockholm exported to Uppsala and Uppsala to Umeå. The role of Lund as producer and exporter of professors appears more clearly if we consider the whole period since the Second World War.

The process of becoming a professor in the Swedish system is timeconsuming. While the normal age for receiving tenure is about $30-35$ in the United States, the average age for a person's first appointment as a professor of economics in Sweden is around 40. This figure has also been remarkably stable over the past 100 years; it fluctuates between a low of 38 for the period 1901-30 and a high of almost 46 in 
the period 1951-60, and it has been around 42 in the 1980s (table 2.4). The expansion in the field can also be seen in table 2.4. For the first three decades of the century a new professor was appointed every third year. The number increased gradually, reaching a peak of two professors a year in the 1980s when the number of new chairs increased.

\section{INTRAMURAL ACTIVITIES OF THE PROFESSORS}

In the Swedish system professors enjoy a strong position in the power hierarchy. They are tenured for life as civil servants and are guaranteed job security, even if they neglect research, publication and involvement in the administration of their departments. Until recently the salary of a professor was based solely on seniority. ${ }^{19}$ The position of the professor is strengthened by the fact that professors appoint new professors according to the system of evaluations. The professor is also an influential member of a department who exerts control over local academic affairs. As such, he can influence the hiring of economists to positions below his own. The status and influence of the professor is still high in the Swedish system, although the power of the individual professor has been reduced as departments have grown in size. The Swedish system of professors as civil servants employed by the government resembles the continental European arrangements rather then the American model.

There is little direct pressure from the student side on the behaviour of professors. According to government policy university degrees should be of equivalent value at all universities. In comparison with the United States there is little information about the quality of the different departments of economics, and the incentive to move from one department to another is weaker in Sweden. Swedish undergraduate students in economics generally pursue their postgraduate studies at their old university. There are no published department rankings as there are in America (cf. e.g. Colander 1989b), nor do Swedish doctoral students discuss their choice of graduate school as American students do (Klamer and Colander 1990).

Once someone has become a professor, he tends to remain in his chair until retirement, at least nominally. Over the past hundred years sixteen professors have thus remained in their professorships for more than twenty-five years (table 2.5). There is little movement among tenured professors from one department to another. Professors sometimes use their position as a base for other activities, however, taking full or partial leave of absence for other tasks, as will be discussed below. 


\section{Introduction and background studies}

Table 2.4 Age at the first appointment as professors in economics or related subjects in Sweden 1889-1989

\begin{tabular}{|c|c|c|c|c|c|c|c|}
\hline Age & $1901-30^{\circ}$ & $1931-50$ & $1951-60$ & $1961-70$ & $1971-80$ & $1981-9$ & Total \\
\hline 30 & 2 & & & & & & 2 \\
\hline 31 & & & & & & & 0 \\
\hline 32 & 1 & & & & & & 1 \\
\hline 33 & & & & & 1 & 1 & 2 \\
\hline 34 & & & & 1 & 1 & & 2 \\
\hline 35 & 1 & 1 & & & 2 & & 4 \\
\hline 36 & 1 & 1 & & & 1 & & 3 \\
\hline 37 & & 1 & & & & 2 & 3 \\
\hline 38 & 1 & & & & 1 & 1 & 3 \\
\hline 39 & 2 & 3 & 1 & 1 & & 1 & 8 \\
\hline 40 & & 1 & 1 & & 3 & 2 & 7 \\
\hline 41 & & 1 & & 1 & 1 & 2 & 5 \\
\hline 42 & & & 1 & & & 2 & 3 \\
\hline 43 & & 1 & 1 & 2 & 1 & 1 & 6 \\
\hline 44 & 1 & & & 3 & & 2 & 6 \\
\hline 45 & 1 & & & 2 & & 1 & 4 \\
\hline 46 & & & & & & 1 & 1 \\
\hline 47 & & 1 & & & & 1 & 2 \\
\hline 48 & & & & & 1 & & 1 \\
\hline 49 & & & & & & & 0 \\
\hline 50 & 1 & & & & & & 1 \\
\hline 51 & & 1 & & & & & 1 \\
\hline 52 & & & & & & & 0 \\
\hline 53 & & & & & & & 0 \\
\hline 54 & & 1 & & & & 1 & 2 \\
\hline 55 & & & & & & & 0 \\
\hline 56 & & & & & & & 0 \\
\hline 57 & & & & & & & 0 \\
\hline 58 & & & & & 1 & & 1 \\
\hline 59 & & & & & & & 0 \\
\hline 60 & & & & & 1 & & 1 \\
\hline $\begin{array}{l}\text { Total } \\
\text { Per }\end{array}$ & 11 & 12 & 4 & 10 & 14 & 18 & 69 \\
\hline Year & 0.32 & 0.60 & 0.40 & 1.00 & 1.40 & 2.00 & 0.80 \\
\hline Median & 38 & 39.5 & 41 & 43.5 & 40.0 & 41.5 & 40.0 \\
\hline Mean & 38.1 & 41.8 & 41.0 & 42.2 & 41.6 & 41.8 & 41.0 \\
\hline
\end{tabular}

Note: "The first modern professor, David Davidson, has been included in this period though he was appointed in 1889. Professors with only the title and professors in economic history are not included.

After appointment the incentive structure to which the now tenured professor had become accustomed, changed drastically, going more or 
Table 2.5 Length of service as professor, 25 years or more

\begin{tabular}{lcl}
\hline Name & Number of Years & Period \\
\hline Bertil Ohlin & $36^{\mathrm{a}}$ & $1929-65$ \\
Eli Heckscher & $36^{\mathrm{b}}$ & $1909-45$ \\
David Davidson & 30 & $1889-1919$ \\
Sven Brisman & 29 & $1917-46$ \\
Gustav Cassel & 29 & $1904-33$ \\
Gösta Bagge & 28 & $1921-49$ \\
Torsten Gărdlund & 28 & $1947-63$ \\
& & $1965-77$ \\
Erik Lundberg & 28 & $1946-74$ \\
Tord Palander & 28 & $1941-69$ \\
Erik Dahmén & 27 & $1958-85$ \\
Ragnar Bentzel & 26 & $1959-85$ \\
Erik Lindahl & 26 & $1932-58$ \\
Anders Ostlind & 26 & $1953-79$ \\
Gustaf Steffen & 26 & $1903-29$ \\
Assar Lindbeck & 25 & $1964-$ \\
Ingvar Svennilson & 25 & $1947-1972$ \\
\hline
\end{tabular}

Notes: ${ }^{2}$ Bertil Ohlin's sojourns as professor in Copenhagen 1924-9 is not included in the table.

${ }^{b}$ Eli Heckscher was professor of economic history 1929-45.

less into reverse. Now the relation between salary and position on the one hand and scientific output on the other is weak. This is one explanation why some professors significantly reduce their production of scholarly work after their appointments. ${ }^{20}$ However, the slowdown in productivity is due partly to the fact that the professor is now responsible for teaching, administration and the supervising of doctoral students, partly to heavy involvement in extramural activities, and partly to the high average age, about 42 , at which a chair is attained in the Swedish system.

Swedish professors have not shown much interest in emigration. The only professors to have left Sweden for professorships outside the country are Roland Artle in 1970 and the two Danes Kjeld Philip in 1951 and Bent Hansen in $1967 .^{21}$ The second two both went to Berkeley. Offers of chairs in the United States have also been extended to several professors such as Erik Lundberg, Assar Lindbeck and Karl-Gustaf Löfgren, but have been turned down. However, in recent decades several economists with a licentiate or a doctor's degree who have not secured a chair in Sweden have left the country to become professors abroad. There are also a number of economics professors of Swedish nationality active outside the country, primarily in the United 


\section{Introduction and background studies}

States, who left as undergraduate or postgraduate students and obtained a degree at a foreign university. This pattern is also fairly new, starting in the 1960s.

Swedish professors usually have good international contacts. They have spent time at foreign universities either as students, postdoctoral visitors or visiting professors. These international contacts have a long history, going back at least to the foreign sojourns of Davidson, Wicksell and Cassel. There has also been a considerable inflow of visiting foreign professors, particularly during the 1980 s.

The supervising and training of doctoral students has not generally been an important part of the activities of Swedish professors. Doctoral students have sometimes even been regarded as a timeconsuming burden, especially in small departments with weak or nonexistent doctoral programmes. Ph.D. programmes on American lines started to appear in the 1960 s, before which time doctoral students would simply read a certain specified amount of literature and then be examined by the professor. A study trip to a foreign university was often part of the preparation for writing a thesis. Formal Ph.D. programmes were not established in Swedish departments until the 1970s. ${ }^{22}$

The number of $\mathrm{Ph} . \mathrm{D}$. students supervised by any of the best-known Swedish economists is amazingly low. David Davidson was professor for thirty years in Uppsala. Only one of his students, that is Eli Heckscher, became professor. Knut Wicksell was professor for such a short period in Lund that he never had any doctoral students. He inspired Emil Sommarin but did not take part in his work, nor did he see Erik Lindahl's thesis until it was available in proofs. His students were law students and economics was a peripheral subject in the law degree. Moreover, Wicksell's firm adherence to Malthusian principles may have repelled students; he was quite open about wanting them to adopt a Malthusian approach. Nor did Eli Heckscher produce any doctors who became economics professors during his own 36-yearlong professorial reign. The reason was that the Stockholm School of Economics had no doctoral progamme until the 1940s, although in his memoirs Ohlin admits to being greatly influenced by Heckscher. ${ }^{23}$

Few of the professors belonging to the Stockholm School inspired any academic followers. Some of them produced no doctors of their own who subsequently obtained economics professorships in Sweden. This applies to Bertil Ohlin and Gunnar Myrdal. Both Ohlin and Myrdal, as will be seen below, became active in political life and for long periods were professors in name only. ${ }^{24}$ Erik Lundberg was more successful as a supervisor, particularly for licentiate students, although 
he was known to be critical in a destructive way. This is one factor behind the demise of the Stockholm School - a school with no followers does not survive. ${ }^{25}$

Before the 1970s and 1980s there were at least two major exceptions to the pattern described here: Gustav Cassel at Stockholm and Johan Åkerman at Lund. Discussing at some length his role as postgraduate supervisor, Gustav Cassel declared:

At the postgraduate level I never had many students. In my opinion the important task was to train not many economists, but economists of high class who could advance the science of economics and improve its position in our country. Under these circumstances, it was no easy task for a professor to judge which students he should admit into the field. He has an enormous responsibility both towards society and towards the individual student. But the professor must bear this responsibility.

(Cassel 1941: 373)

As supportive evidence of his policy Cassel described the careers of those of his students who were professors at the time when he was writing his memoirs: Nils Wohlin, professor of statistics, and Gösta Bagge, Bertil Ohlin and Gunnar Myrdal, all three professors of economics. Cassel (1941: 377) also singled out two students whom he felt had 'good knowledge' but whom he did not want to let into the academic field, namely Gunnar Silverstolpe and Karl Petander: 'Both, as I see it, have subsequently found the right place in life. [. . .] Karl Petander has become an excellent teacher at a community college, and I am convinced that this position has given him far better opportunities for using his resources than if he had become a professor. ${ }^{26}$

Johan Åkerman is the second exception. He was the supervisor of several students such as Erik Dahmén, Lars Werin, Bengt Höglund and Bengt-Christer Ysander, who reached chairs later in life. ${ }^{27} \mathrm{He}$ had a tolerant attitude towards his students, encouraging them to write on a wide variety of topics. In his opinion, economics should be regarded as a social science covering history, political science and law.

Over the last few decades, with the development of formalized Ph.D. programmes on American lines, professors have become more closely engaged in the supervising of doctoral students. There are now several professors who have supervised a substantial number of economics doctors. The production of the thesis, however, is still left much more to the candidate than is the case in the United States.

Another peculiar feature of academic economics in Sweden used to be the animosity the professors felt for one another. (This applies in 


\section{Introduction and background studies}

other disciplines as well.) The incentive structure and the limited number of chairs probably played a part here too, along with differences in personality and political outlook. The academic tradition of destructive criticism, of finding weaknesses in the work of others, did not foster friendship and cooperation. ${ }^{28}$ The small size of the departments - and we cannot even talk about regular departments until the 1950s - and the monopolistic position of the professors encouraged rivalry, or at least a lack of cooperation, in the profession. The rift between Cassel and Wicksell is well known. The two men differed in economics, politics and moral outlook. When he was asked by the Economic Journal to write an obituary on Wicksell, Cassel passed the task on to others.

The list of less-than-friendly relationships (some more enduring than others) in the interwar period is not short, particularly considering the size of the profession (most disputes involved Heckscher, who set a high standard for himself and others): Heckscher-Cassel (Heckscher thought Cassel was too sloppy in his conclusions); HeckscherOhlin (Heckscher believed Ohlin had accepted double pay as professor in Copenhagen and Stockholm when he transferred to Stockholm); Heckscher-Lindahl (Heckscher thought Lindahl had misused a scholarship); Heckscher-Bagge (Heckscher felt exploited by Bagge for a long time and broke with him in 1934); Heckscher-Myrdal (Heckscher published a highly critical review of Myrdal's book on the population issue in 1935, and disliked Myrdal's socialist leanings); Ohlin-Hammarskjöld (starting most likely when Ohlin acted as an opponent when Hammarskjöld defended his thesis, and continuing when they worked on the Unemployment Committee); Bagge-Lindahl (they stopped talking to each other after Lindahl's divorce and when Lindahl failed to deliver as promised on the Rockefeller project); Bagge-Myrdal (starting with a conflict involving Alva Myrdal on the population issue) and Bagge-Ohlin (Bagge, a strong opponent of Nazism, accused Ohlin in 1940 of writing in a pro-German newspaper. Ohlin responded by breaking with Bagge.) Similar patterns can be found in the postwar period, perhaps most notably the rift between Lindahl and Palander in Uppsala. In the American system such conflicts are usually eliminated by the high mobility in the profession. In the Swedish system, however, this safety valve hardly exists, as there is so little mobility between the universities.

Another characteristic of Swedish economics has been the lack of a common $\mathrm{Ph}$.D. programme, a common professional organization like the American Economic Association with its prestigious journals, and a common 'paradigm'. ${ }^{29}$ Here Sweden belongs to the European 
tradition as illustrated by Coats (1985) and Portes (1987) among others. There are signs that Sweden will break away from the old European pattern. However, the absence of a well-functioning competitive labour market for academic economists similar to the American market inhibits the rise of an economics profession and mobility of the American kind.

\section{EXTRAMURAL ACTIVITIES OF THE PROFESSORS}

A striking feature of the Swedish economics profession, in contrast to most other countries, is the heavy involvement of its professors in public life. This is a tradition going back to the founders of economics in Sweden, to Wicksell, Cassel and Heckscher. They set an example that has influenced Swedish economists ever since. Professors though they might be, they were also deeply involved in popular enlightenment, as journalists, lecturers, debaters, opinionmakers, members of parliamentary committees and general advisers.

Wicksell and Cassel saw it as their mission or duty to promote the cause of economic analysis and to fight ignorance and prejudice as they themselves defined it. Both spent much time as public lecturers. Wicksell spoke to the workers at trade union and other radical meetings, while Cassel's audiences came mainly from the upper strata of society. For a time Cassel even taught economics at the royal court. Heckscher was also a public lecturer, and was the first economist to use the radio for teaching economics during the 1920s. All these men were active in the public debate, discussing current economic and political issues. Consequently, they also published a great many articles. Wicksell wrote in a wide variety of newspapers. Cassel published about 1,500 articles in the conservative Stockholm daily newspaper, Svenska Dagbladet, and Heckscher published around 300 articles in its liberal rival, Dagens $N y$ heter (see table 2.6.).

The founding fathers also served as advisers or consultants in various capacities and at various times: Wicksell to the Riksbank, Heckscher to the government during the First World War, Cassel to one of the major commercial banks (Skandinaviska Kreditaktiebolaget), and so on. They contributed to government commission reports and to parliamentary commissions investigating various issues. They worked as experts or as members of such commissions.

This pattern of public service has been copied by later generations of economists. The members of the Stockholm School were as active in the public arena as the founding fathers. Ohlin was a most prolific 


\section{Introduction and background studies}

Table 2.6 Number of newspaper articles published by Knut Wicksell, Gustav Cassel, Eli Heckscher and Bertil Ohlin

\begin{tabular}{|c|c|c|}
\hline Name & Number of articles & Source \\
\hline Knut Wicksell & about $450^{\circ}$ & Knudtzon (1976) \\
\hline Gustav Cassel & $1,506^{\mathrm{b}}$ & Carlson and Jonung (1989) \\
\hline Eli Heckscher & about 300 & $\begin{array}{l}\text { Eli Heckscher's bibliography } \\
\text { 1879-1949, Stockholm, } 1950\end{array}$ \\
\hline Bertil Ohlin & about 2,000 & $\begin{array}{l}\text { Personal communication with } \\
\text { Bertil Ohlin }\end{array}$ \\
\hline
\end{tabular}

Notes: "The number of articles written by Wicksell has been estimated from his bibliography allowing for double-counting. His correspondence with Finnish newspapers published in Finnish are not included. Wicksell's unpublished manuscripts - most of them aimed for newspapers - amount to about 100 . These are not included in the table.

- The figure refers only to Cassel's articles in Svenska Dagbladet published in the period 1903-44. Cassel also published in foreign newspapers as well as in other domestic newspapers and journals, such as the journal of the Swedish Taxpayers' Association.

writer of newspaper articles (table 2.6). ${ }^{30}$ In fact their generation worked more actively as policy advisers and became more deeply involved in party politics than their predecessors. Wicksell remained a radical liberal and never joined any party; Cassel was asked to run as a conservative but was turned down when he said he wanted to be completely independent of the party; Heckscher remained a consistent economic liberal after his break with conservatism but stayed out of Parliament.

All those of Cassel's students who became professors with the exception of Silverstolpe, also became members of Parliament, but they represented different parties: Nils Wohlin, the Agrarian Party; Bertil Ohlin, the Liberal Party; Gunnar Myrdal, the Social Democratic Party, and Gösta Bagge, the Conservative Party (table 2.7). Other Swedish professors of economics have shown great interest in becoming members of Parliament, as seen in table 2.7. In the 1970s and 1980s Hugo Hegeland, Staffan Burenstam Linder and Bo Södersten served in Parliament. While they were members they were automatically given leave of absence from their professorships.

Swedish economists since the Second World War have continued in the tradition of participating in the public debate. They have published extensively in the Swedish press (table 2.8). Several have published more than a hundred articles. The younger generations seem to be 
Economics the Swedish way 1889-1989

Table 2.7 Professors in economics as members of Parliament

\begin{tabular}{|c|c|c|c|}
\hline Name & $\begin{array}{l}\text { Year of } \\
\text { appointment } \\
\text { as professor }\end{array}$ & $\begin{array}{l}\text { Party } \\
\text { affiliation } \\
\text { or estate }\end{array}$ & $\begin{array}{l}\text { Period in } \\
\text { Parliament }\end{array}$ \\
\hline \multicolumn{4}{|l|}{ Ancestors } \\
\hline Carl Adolph Agardh & 1812 & Clergyman & $\begin{array}{l}1817-18 \\
1823 \\
1834-59\end{array}$ \\
\hline Theodor Rabenius & 1854 & Nobleman & $1862-3$ \\
\hline Gustaf Hamilton & 1862 & Nobleman & $\begin{array}{l}1862-3 \\
1865-6\end{array}$ \\
\hline Jacob Georg Agardh & 1854 & & $1867-72$ \\
\hline Carl Hammarskjöld & 1877 & & $\begin{array}{l}1879-81 \\
1895-7\end{array}$ \\
\hline \multicolumn{4}{|l|}{ Modern age } \\
\hline Gustaf Steffen & 1903 & $\begin{array}{l}\text { Social } \\
\text { Democrat }\end{array}$ & $1911-16$ \\
\hline Gösta Bagge & 1921 & Conservative & $1932-47$ \\
\hline Gunnar Myrdal & 1933 & $\begin{array}{l}\text { Social } \\
\text { Democrat }\end{array}$ & $\begin{array}{l}1936-8 \\
1944-7\end{array}$ \\
\hline $\begin{array}{l}\text { Bertil Ohlin } \\
\text { Staffan Burenstam }\end{array}$ & 1929 & Liberal & $1938-70$ \\
\hline $\begin{array}{l}\text { Linder } \\
\text { Bo Södersten }\end{array}$ & $\begin{array}{l}1979 \\
1971\end{array}$ & $\begin{array}{l}\text { Conservative } \\
\text { Social }\end{array}$ & $1969-86$ \\
\hline Hugo Hegeland & 1965 & Democrat & $\begin{array}{l}1979-88 \\
1982\end{array}$ \\
\hline
\end{tabular}

following the pattern of their elders according to table 2.8 . The advent of Ekonomisk debatt in 1973, the journal of the Swedish Economic Society (Nationalekonomiska föreningen), has given the economists a new forum which has been eagerly exploited. This journal, published eight times a year, is frequently quoted in the press. It has been the training ground of young economists just starting to write. It has been an outlet for doctoral students, doctors, docents and professors interested in practical issues and the current policy debate. Ekonomisk debatt partially fills the niche once occupied by Ekonomisk tidskrift before it became first the Swedish Journal of Economics and later the Scandinavian Journal of Economics.

Most professors of economics have served either as members or experts on government committee reports (SOU), on the Long-term Planning Commission (Langtidsutredningen), or providing background 


\section{Introduction and background studies}

Table 2.8 The publication record of 37 Swedish professors in economics living in 1989

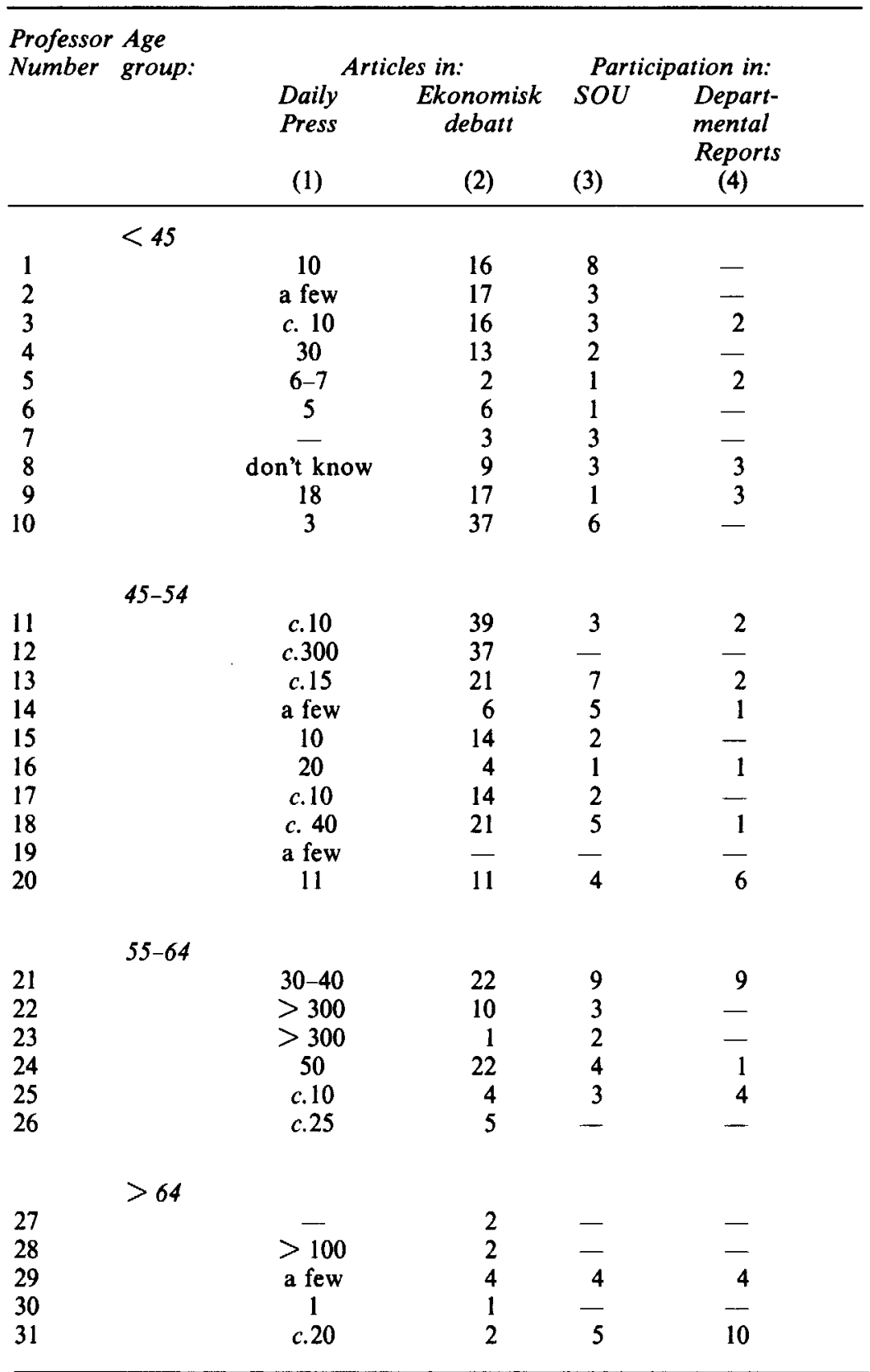


Table 2.8 Continued

\begin{tabular}{|c|c|c|c|c|}
\hline \multirow[t]{2}{*}{$\begin{array}{l}\text { Professor Age } \\
\text { Number group: }\end{array}$} & \multicolumn{2}{|c|}{ Articles in: } & \multicolumn{2}{|c|}{ Participation in: } \\
\hline & $\begin{array}{c}\text { Daily } \\
\text { Press } \\
\text { (1) }\end{array}$ & $\begin{array}{c}\begin{array}{c}\text { Ekonomisk } \\
\text { debatt }\end{array} \\
\text { (2) }\end{array}$ & $\begin{array}{l}S O U \\
\text { (3) }\end{array}$ & $\begin{array}{l}\text { Depart- } \\
\text { mental } \\
\text { Reports } \\
\text { (4) }\end{array}$ \\
\hline 32 & 12 & 2 & 35 & 1 \\
\hline 33 & $c .170$ & 6 & 4 & - \\
\hline 34 & $c .220$ & 2 & 21 & 1 \\
\hline 35 & 1 & - & 1 & - \\
\hline 36 & $50-70$ & 9 & 2 & 1 \\
\hline 37 & c. 300 & - & 2 & - \\
\hline
\end{tabular}

Source: The table is based on a mail survey of all professors of economics, active or retired, and still living in 1989. A few professors failed to respond. The table does not include articles in professional journals and books or monographs.

material for departmental reports (table 2.8). Whenever an issue involving economic factors is being explored, the rule is that economists should be involved. The employment of economists at high levels in the Ministry of Finance has increased the demand for economists and facilitated their participation in government work. Economists have also served as advisers in various capacities to the government, the opposition, the Riksbank, special-interest groups, banking and industry. The liberalization of the Swedish capital market in the 1980s has also increased the demand for economists specializing in finance as consultants and analysts.

Economists have taken an active part in practically every public debate of importance in the postwar period. In the 1940s and 1950s they participated in the debate on planning. Many economists in Sweden were pro-planners, in particular those who had turned to social democracy in the 1930s, such as Gunnar Myrdal and Karin Kock. However, some members of the Stockholm School, such as Bertil Ohlin and Erik Lundberg, remained in the liberal camp. In the 1960s most economists adopted a Keynesian outlook and were in favour of government intervention (Pigouvianism). This stance has shifted remarkably in recent decades. Economists gradually adopted a more critical attitude towards government intervention, reverting to severe criticism of regulations on the credit and capital market and in the housing sector, of price controls and farming subsidies, of tariffs and restrictions on trade. Now they advocate market-oriented solutions to a far greater extent than in the 1950s and 1960s. ${ }^{31}$ 


\section{Introduction and background studies}

Table 2.9 Percentage distribution of citations by language of source in Ekonomisk tidskrift and its successors: 1900, 1935, 1970 and 1988

\begin{tabular}{lrrrr}
\hline Language & 1900 & 1935 & 1970 & 1988 \\
\hline & & & & \\
English & 15.9 & 30.1 & 79.0 & 97.5 \\
French & 4.3 & 4.1 & 1.3 & 0.4 \\
German & 40.6 & 12.3 & 0.0 & 0.6 \\
Scandinavian & 39.1 & 53.4 & 19.6 & 1.5 \\
\hline Total & & & & \\
\hline Total citations & 69 & 73 & 153 & 520 \\
\hline
\end{tabular}

Source: The data for 1900, 1935 and 1970 are taken from Stigler and Friedland (1979, Table 2). In case a bibliography of Robert Solow (Nobel Laureate) is included in the citation count for 1988, 195 entries are added to the English references raising this share from 97.5 to 98.2 per cent.

This active participation by economics professors in public life has not turned them into obedient social engineers, however, or mandarins in the service of a growing public sector or of the Social Democratic Party, which had a monopoly of the political power for most of the postwar period. There was a tendency in this direction particularly in the late 1940s and during the 1950s, but the independent position of the professors prevented it from developing. Two of the most active professors in the public debate in the 1980s, Assar Lindbeck and Ingemar Ståhl, even moved away from their earlier social democratic stance of the 1950 s towards a more liberal view. ${ }^{32}$

During the 1980s there was a marked tendency towards a division of labour in the practice of economics. A number of high-ranking economists have abandoned university life to pursue careers in the economics divisions of commercial banks, in research institutes or in the organizations of special-interest groups. In such capacities they have been active participants in the public debate on economic issues challenging the position previously held by professors. They have also enjoyed the assistance of staffs, not available to university professors, to help them in their investigations.

The independence of many economics professors - including those with social democratic leanings - combined with their propensity to take part in the public debate and to come forward openly with their criticisms of those ruling the country, contrasts sharply with attitudes in the field of political science. Professors there have been more eager 
to cooperate with the local and national authorities and less apt to express critical views in the same way as the economists. ${ }^{33}$

The public activities of the economists have given them a prominent position in Swedish political life, as the memoirs of several politicians have confirmed. Tage Erlander, prime minister from 1946 to 1969, was inspired to study economics in Lund by Wicksell's reputation. In his autobiography, Ernst Wigforss, minister of finance from 1932 to 1949, expressed his admiration for his political adversary Eli Heckscher. More recent biographies by politicians, such as that of the former Conservative Party leader Gösta Bohman, all mention economists in various capacities.

A peculiar feature of Swedish economics is the almost complete absence of any influence or impact from Marxism. To my knowledge no Swedish economist, after becoming a professor of economics, has ever openly declared himself to be a Marxist. Many have been socialists or social democrats, however. This absence of Marxism may be partly due to Knut Wicksell's harsh criticism of Marx. Wicksell was highly regarded in the social democratic movement as well as in the economics profession. Unlike the older generation, the members of the Stockholm School who were drawn to the left did not accept any communist or Marxist influence. The 1968 New Left had no impact on Swedish economics. In this context Assar Lindbeck (1971) adopted a stance that was representative of the attitude of most economists. The Marxism of the 1960s and 1970s did gain a strong foothold in Swedish economic history, however, and its influence is still noticeable in some university departments.

\section{FOREIGN INFLUENCES ON SWEDISH PROFESSORS}

Sweden is commonly characterized as a small open economy. This description also applies to the field of economics. The founders, Davidson, Wicksell, Cassel and Heckscher, were all affected by outside influences, that is to say by foreign economics. Wicksell and Cassel travelled and studied extensively abroad, especially in Germany and England. They brought Swedish economics to the forefront of economic science by transforming their intellectual imports into genuine Swedish products that could be successfully re-exported, while also establishing the domestic tradition. They each published an influential textbook - Wicksell his Lectures and Cassel the Theory of Social Economy - that gained international recognition at least in the German-speaking world.

The next generation, the Stockholm School, was then able to build 


\section{Introduction and background studies}

successfully upon the work of the founding fathers. During the $1920 \mathrm{~s}$ and 1930s they established a domestic product which depended very little on imported elements, and which was probably the most original contribution made by Swedish economics. As they published to a considerable extent in Swedish, the local character of their work was enhanced; the theses produced by Ohlin (1924), Myrdal (1927) and Svennilson (1938) were all in Swedish. Not until they started to publish in English did they make any impact on the international scene. $^{34}$

The Second World War marked the end of the Stockholm School. The war isolated Sweden scientifically. The members of the School were drawn into public service; the pro-interventionist bias of the School encouraged such a move. Some of them, such as Gunnar Myrdal and Ingvar Svennilson, became engaged in planning the postwar Swedish economy. After the war the American dominance increased while the domestic tradition gradually declined. This development had begun in the interwar years as a result of Gösta Bagge's involvement with the Rockefeller Foundation. Swedish economists went to the United States in the interwar period, while the German influence declined.

The small academic base in Sweden could not remain immune to the Anglo-American Hicks-Samuelson onslaught. The theories of the Stockholm School were not available in any textbook version which could be handed down to new generations of students. The oral tradition was too weak to survive. Admittedly Erik Lundberg's book on business cycles and economic policy published in 1953 almost counted as a textbook, but it lacked any explicit models and put too great a burden on both teachers and students to be used in undergraduate training.

Swedish economists still published in Swedish in the government commission reports and in Ekonomisk Tidskrift until the latter became the Swedish Journal of Economics and later the Scandinavian Journal of Economics. By now English had become the universal language of economics. Today papers are written in English and are aimed at an international English-speaking audience. The rise of English and the decline of Swedish and other languages is demonstrated in table 2.9, which shows the distribution of citations by language of source in Ekonomisk Tidskrift and its English-language successors in 1900, 1935, 1970 and 1988. German and Scandinavian quotations dominated in 1900; the figures were 41 and 39 per cent respectively. The English share was 16 per cent. By 1935 the English share had doubled, the German had fallen sharply, and the Scandi- 
navian languages were peaking. From then on the English dominance advances rapidly, reaching total hegemony in 1988, when English replaced Swedish as the language of the journal. All other languages are assigned to oblivion.

For a long time the lack of any American-style doctoral programmes kept Swedish economics at a disadvantage. As we have seen, Swedish doctoral students would be left to find thesis topics on their own. ${ }^{35}$ The successful American system has attracted many Swedish students. During the 1970s and 1980s the flow of students from Sweden to American graduate schools, encouraged by generous stipends and grants, has been considerable. As a result a number of Swedes with a Ph.D. from the United States have returned to Sweden and competed successfully for chairs. Four current professors have doctoral degrees from the United States (Sören Blomqvist, Lars Jonung, Johan Lybeck and Clas Wihlborg).

The American training of Swedish economists has contributed to the dominance of the United States. American values as regards academic performance have collided with traditional Swedish ideas. Most of the younger economists adhere to American publication practice, aiming to publish articles in refereed journals. The old tradition of writing monographs still exists, but is not as fashionable as it once was. The emphasis is now on the rigorous application of mathematical and statistical techniques. Doctoral candidates aiming at an academic career write their theses in English, attempting to build upon the latest international results. In this way the corps of Swedish economists is becoming professional to an extent unmatched before. There are signs that the skills and knowledge of a good Swedish economics Ph.D. are slowly converging with those of a Ph.D. from a good American department.

Academic research in Sweden is now part of the international economics marketplace, in roughly the same way that research by economists in the state of Michigan does not differ much from the research of their colleagues in other parts of the United States. Swedish economists active in research are often linked into various international networks. They generally accept American models and techniques and try to improve upon these. There is no common principles textbook in Swedish. This important section of the literature is completely dominated by the standard American products. 


\section{Introduction and background studies}

\section{FINAL REFLECTIONS}

Over the past century Swedish academic economists have been successful in establishing a strong position for their field of study. They have been successful in research, and in particular the first two generations of economists have made substantial scientific contributions. The period 1899-1939 was the golden age of Swedish economics. After this it declined towards a more average level. However, there are signs of a new upsurge following the rapid increase in the number of professorships in the 1980s. A new generation of professors (the baby boomers) may bring about a renaissance. The subject is currently well represented in undergraduate courses in Sweden, and this encourages the recruitment of new students.

Swedish economists have been very active outside the academic arena - lecturing, writing in journals and newpapers, engaging in the public debate, and running for Parliament. Their advice has been much in demand, and the profession has been ready to give it. The economists have generally been respected for their competence, and they have managed to maintain this respect in the public mind over a long period, in spite of differences of opinion - some of them displayed in public. The establishment of the Nobel Prize in economics may be regarded as evidence of the strong position of the subject in Sweden.

Swedish professors are traditionally appointed by the King-inCouncil. In other words they are employed as civil servants with tenure for life. However, they have not seen themselves as civil servants, nor have they behaved as such. Rather, as a group they have been ready to express their criticism openly and to take part in the public debate, free from any outside pressure. No Swedish professor of economics has been fired or pressed to resign on political grounds.

The heavy involvement in practical affairs has been both detrimental and beneficial to the development of academic economics: beneficial because it promotes the recruitment of undergraduate and postgraduate students and persuades economists to do applied work; detrimental because it distracts from doing theoretical work and creates a sceptical attitude towards what Erik Lundberg called 'Alpine economics', by which he meant theoretical economics with little or no empirical relevance. We could probably say that this pull towards practical or topical issues is, for good or ill, the dominant feature of 'economics the Swedish way'. 


\title{
3 The economics of Swedish economics in the 1980s
}

\author{
Peter Stenkula and Lars Engwall
}

\section{THE SWEDISH SYSTEM FOR ALLOCATING RESEARCH GRANTS}

\section{General features}

Broadly speaking the funds for Swedish academic economics research emanate from two sources: government allocations to the faculties of the universities ('faculty grants') and grants from a variety of researchfinancing bodies. Government resources are allocated for permanent or temporary positions, and to some extent also for projects of limited duration. Other research-financing bodies, on the contrary, allocate funds primarily to specific projects after application has been made, although chairs and research positions of limited duration are sometimes also created.'

\section{Faculty grants}

The faculty grants constitute the fixed research resources of the universities, and they are allocated to faculties and departments by way of a political process. The highest decision-making body is the Swedish Parliament, which makes the overall decision on allocations following a proposal from the Ministry of Education. According to the original procedure, which nowadays takes place every third year, the individual university departments submit proposals to their faculty boards, which after internal adjustments send their requests on to the Ministry of Education. Each university board comments on the faculty submissions, as does the Office of Swedish Higher Education (UHÄ). ${ }^{2}$ The proposals are generally based on estimates of future fixed research-resource requirements for the different research fields. The significance of the various arguments are examined in a final 


\section{Introduction and background studies}

screening at the Ministry, where certain priority rules may govern the decisions. In recent years, for example, there has been a tendency to allocate fixed research resources to specific problem areas. ${ }^{3}$

The allocation of research funds from the Ministry is basically independent of the volume of the undergraduate programmes, and the two areas are funded quite separately. A Swedish university department therefore also embraces two categories of academic employees financed in different ways: first the research positions (nowadays chairs or a temporary position as forskarassistent, earlier also a temporary position as docent) financed by faculty grants and second, the teaching positions (högskolelektor), which involve full-time teaching duties and which are financed by grants for educational programmes. The only link is that the lecturers may apply for internal research funds (rörlig resurs) ${ }^{4}$ In addition it is of course possible for anybody to apply for research positions that happen to become vacant. Candidates for positions are then chosen on a basis of their previous performance, whereas research money is allocated after the quality and feasibility of competing research proposals have been evaluated. In the case of research positions, permanent or temporary, appointees are essentially free to choose their line of research. Chairs or research positions with some special focus will naturally mean special requirements as regards research orientation. As we have seen in Chapter 2 the relative freedom of appointees in this connection has meant that the ability of potential future researchers is first subjected to a thorough examination.

\section{Research grants}

Among the sources of research grants a distinction has to be made between (1) organizations exclusively supporting basic research, (2) applied research-granting bodies and (3) various private foundations. They differ both in terms of their orientation, and the principles that steer their resource-allocation procedures.

\section{Organizations exclusively supporting basic research}

After the Second World War a number of research councils were created in Sweden. ${ }^{6}$ There were separate councils for the fields of nuclear physics, medicine, science, technology, the social sciences and the humanities. With the passage of time the councils have acquired an important role in the allocation of research funds. Some restructuring has occurred during the last few decades: among other things the two 
research councils for the humanities and the social sciences were merged to form the present HSFR in 1977.

The research councils receive their resources as a result of a political process in much the same way as the universities, i.e. they submit applications to the Ministry of Education and compete with other areas for funds from the state budget. The final allocation of grants from the councils is decided by the councils themselves, following the screening of applications from individual researchers. ${ }^{7}$

The research councils consist mainly of elected members representing holders of permanent research positions at the universities, and a minority of members appointed by the government. ${ }^{8}$ The research councils have a number of working groups for screening the applications and setting priorities within specific fields. These decisions are based primarily on the perceived quality of the research proposals. The council then has to set priorities between the different fields of research within its jurisdiction. Needless to say these priority decisions between fields are not always free of complications.'

Another Swedish body which provides research grants for basic research in all scientific disciplines is the Bank of Sweden Tercentenary Foundation, founded in $1965 .{ }^{10}$ The Foundation started with a capital of SEK 250 million to be invested in bonds; the return on this investment was to be allocated to research projects. Later the Foundation was granted additional capital, and since January 1988 it has enjoyed complete freedom in investing its money. "The Board of the Tercentenary Foundation consists of representatives of the research community, financial experts and members of Parliament. Like the research council it has a number of screening groups. In addition the Foundation also employs a referee system. ${ }^{12}$ One ambition, not always fulfilled, has been to give priority to large projects. ${ }^{13}$

The competition for research grants from the Research Council and the Tercentenary Foundation is tough. At the Foundation, for example, the arithmetic mean of rejection rates in the 1980 s was 66 per cent of the sums applied for, and 56 per cent of the number of applications. ${ }^{14}$ Grants from the Research Council and the Tercentenary Foundation are therefore held in high esteem and considered as indicators of high-quality research.

\section{Organizations supporting applied research}

In addition to funds allocated through the Research Council and the Tercentenary Foundation, considerable funds are channelled through various ministries and government authorities to research of a more 


\section{Introduction and background studies}

applied character. The size of these research grants depends partly on parliamentary decisions and partly on budget decisions within the bodies concerned. The allocation of these research funds has tended to follow less strict procedures than those adopted by the Research Council and the Tercentenary Foundation. Some of the grants are allocated following applications from researchers within specified problem areas, others are distributed as a result of direct contact between individual researchers and officials in the funding bodies. In this second case resource allocation comes closer to a system of payment for commissioned work, and here in particular the allocation of resources to applied research shows us a much fuzzier picture than the system of faculty grants and basic research council grants.

Important financers of applied research include the Swedish Work Environment Fund (Arbetsmiljöfonden), the Swedish Council for Building Research (Byggforskningsrådet), the Energy Research Commission (Energiforskningsnämnden) the Delegation for Labour Market Policy Research (EFA) and the Swedish Agency for Research Cooperation (SAREC). Some of these have been subject to scrutiny, and their resource-allocation practices have been challenged. ${ }^{15}$ As a result some of them have tended towards practices similar to those of the basic research councils. ${ }^{16}$ Some, like SAREC, have also provided funds in recent years for temporary six-year professorships.

\subsubsection{Private foundations}

Yet another source of research funds is provided by a variety of private foundations. ${ }^{18}$ Although they come under general government supervision, they may employ resource-allocation procedures of their own choice. Some foundations have adopted practices similar to those of the research councils, i.e. they open their resources to competition among researchers. Although practices differ, most foundations ask for some kind of formal application and call in expert opinions in order to guarantee the quality of the selected projects.

The private foundations also differ as regards the type of support they provide. Some, like Knut and Alice Wallenberg's Foundation, focus almost exclusively on the financing of equipment. Among the bodies providing funds for research work it is not uncommon to give scholarships. $^{19}$

\section{The total system}

Thus Sweden has a multi-source system of resource allocation, which 
means that individual researchers may have several chances of funding a research project. It has to be kept in mind, however, that Sweden is a relatively small country, which could mean that this is a truth with modifications.

Quality control has traditionally been tighter in the allocation of funds by way of the faculties or research councils. These two types of financing differ mainly in their grounds for selection: the former pay more attention to the researcher's earlier performance and the latter to the research proposals themselves. The applied research projects, on the other hand, can risk diverging from the faculty and research council projects in terms of quality, since the subject of the research often takes precedence over the quality dimension in the selection of projects and researchers. Scholarships are generally distributed according to proven or expected ability.

\section{METHODOLOGICAL ISSUES}

The allocation of research funds to different Swedish university departments can be studied by scrutinizing the annual university reports, which are divided into teaching and research programmes. In this way it is possible to identify resources for research and doctoral programmes in the individual departments.

In order to obtain figures on resource allocations to the Swedish economics departments, the accounts for the academic years 1980-1 to 1989-90 have been obtained from university records. These accounts concern the current resources assigned to research and doctoral programmes, excluding capital costs. Some difficulty arose with regard to figures for external grants, since these are not as easily accessible as the faculty grants. Needless to say, it has not been possible to include in the analysis any scholarships or other grants not administered by the universities.

All the data are given at current prices. For the purpose of comparison, however, they will also be adjusted below to the 1989-90 price level. The adjustment is made with the help of an index which was developed in two earlier studies (cf. Stenkula 1985: 30-6 and 1986: 25-7) and which has been used regularly by the Office of Swedish Higher Education (cf. e.g. UHÄ Report 1986:15: 20). It differs from the consumer price index generally used (KPI) in that it gives more weight ( 80 per cent) to salaries and less weight ( 20 per cent) to current expense costs. ${ }^{20}$

In accordance with the other chapters in this book we have limited our analysis to the Stockholm School of Economics and the five 


\section{Introduction and background studies}

universities of Gothenburg, Lund, Stockholm, Umeå and Uppsala. The Stockholm School of Economics has a different system of resource allocation from that of the universities, so its figures have been estimated to correspond to the faculty grants.

It should be noted that a not negligible amount of economics research takes place outside the units studied, i.e. at university colleges, at independent research institutes, in banks and insurance companies, in consultancy firms, etc. However, it has not been possible to include this in the present study. Likewise economic research at Linköping University and the Agricultural University (SLU) has been excluded.

The following analysis will follow the structure introduced on pages 49-53 above, i.e. faculty grants will be presented first, followed by external grants. In a subsequent section the total resources allocated to the various departments will be analysed. Since the Institute of International Economic Studies (IIES) and the Swedish Institute for Social Research (SOFI) have special research status, they have been considered in the analysis as separate units, although they are formally part of Stockholm University.

\section{FACULTY GRANTS}

\section{Resources allocated to economics}

An analysis of the faculty grants (cf. table 3.1) made to the Swedish economics departments reveals that at current prices these grants have more than doubled, from SEK 11.1 million to SEK 28.5 million, during the period investigated. At fixed prices (i.e. 1989-90), these figures correspond to a relative growth rate of a little under 50 per cent, as the result of an increase in resources from SEK 20.7 million to SEK 28.5 million. The increase has not been continuous, however. The resources, measured at fixed prices, remained virtually unchanged during the first half of the period, and the real change took place in the last three of the years studied. The explanation of this phenomenon is to be found in the increase in basic resources for research and doctoral programmes included in the 1987 Government proposal on research for the three following years (Government Bill 1986/87: 80).

Altogether faculty grants during the period studied amounted to SEK 230 million at $1989-90$ prices. As figure 3.1 shows, there were certain differences in the distribution of these resources between the units studied. Basically three groups can be identified: 
The economics of Swedish economics

Table 3.1 Faculty grants $1980-1$ to $1989-90$ (KSEK)

\begin{tabular}{|c|c|c|c|c|c|c|c|c|c|c|}
\hline Unit & $80 / 81$ & $81 / 82$ & $82 / 83$ & $83 / 84$ & $84 / 85$ & $85 / 86$ & $86 / 87$ & $87 / 88$ & $88 / 89$ & $89 / 90$ \\
\hline \multicolumn{11}{|c|}{ Current prices } \\
\hline $\mathrm{U}$ & 1 & 1,85 & or & 1,9 & & 3 & & & 3,398 & 4,295 \\
\hline IHS & & & & & & 1 & & 1 & & 2, \\
\hline IES & 2,579 & 2,679 & 2,821 & 2,8 & $3,283^{a}$ & 4,812 & 4,516 & 5,672 & 6,015 & 6,46 \\
\hline $\mathrm{U}$ & 1,525 & 1,810 & 2,177 & 1,984 & 2,290 & 2,280 & 2,279 & 2,401 & 2,730 & 2,612 \\
\hline OFI & 918 & 923 & 971 & 931 & 1,138 & 1,210 & 1,642 & 1,733 & 1,915 & 2,787 \\
\hline $\mathrm{U}$ & 1,003 & 1,071 & 1,081 & 1,070 & 1,331 & 1,237 & 1,347 & 1,596 & 1,975 & 2,231 \\
\hline $\mathrm{JmU}$ & 993 & 1,238 & 1,368 & 1,384 & 1,232 & 1,284 & 1,603 & 2,090 & 2,865 & 3,350 \\
\hline IV & 962 & 959 & 1,084 & 1,712 & 1,631 & 1,729 & 1,362 & 1,726 & 2,283 &, 752 \\
\hline
\end{tabular}

Total $11,09011,90612,93713,515 \quad 14,620 \quad 16,29917,29320,00323,83928,488$

Fixed prices (1989/90 price level)

$\begin{array}{lllllllllll}\text { GU } & 3,366 & 3,238 & 3,105 & 2,933 & 2,949 & 2,689 & 2,980 & 3,404 & 3,908 & 4,295 \\ \text { HHS } & 2,450 & 2,408 & 2,494 & 2,537 & 2,475 & 2,444 & 2,882 & 2,434 & 3,057 & 2,995 \\ \text { IIES } & 4,823 & 4,688 & 4,598 & 4,374 & 4,793 & 6,592 & 5,826 & 6,920 & 6,917 & 6,466 \\ \text { LU } & 2,852 & 3,168 & 3,549 & 3,036 & 3,343 & 3,124 & 2,940 & 2,929 & 3,140 & 2,612 \\ \text { SOFI } & 1,717 & 1,615 & 1,583 & 1,424 & 1,661 & 1,658 & 2,118 & 2,114 & 2,202 & 2,787 \\ \text { SU } & 1,876 & 1,874 & 1,762 & 1,637 & 1,943 & 1,695 & 1,738 & 1,947 & 2,271 & 2,231 \\ \text { UmU } & 1,857 & 2,167 & 2,230 & 2,118 & 1,799 & 1,759 & 2,068 & 2,550 & 3,295 & 3,350 \\ \text { UU } & 1,799 & 1,678 & 1,767 & 2,619 & 2,381 & 2,369 & 1,757 & 2,106 & 2,625 & 3,752\end{array}$

Total $20,74020,83621,08820,67821,34422,33022,30924,40427,41528,488$

Relative shares (\%)

$\begin{array}{lrrrrrrrrrr}\text { GU } & 16.2 & 15.5 & 14.7 & 14.2 & 13.8 & 12.0 & 13.3 & 13.9 & 14.3 & 15.1 \\ \text { HHS } & 11.8 & 11.6 & 11.8 & 12.3 & 11.6 & 10.9 & 12.9 & 10.0 & 11.1 & 10.5 \\ \text { IIES } & 23.3 & 22.5 & 21.8 & 21.1 & 22.4 & 29.5 & 26.1 & 28.4 & 25.2 & 22.7 \\ \text { LU } & 13.7 & 15.2 & 16.8 & 14.7 & 15.7 & 14.0 & 13.2 & 12.0 & 11.5 & 9.2 \\ \text { SOFI } & 8.3 & 7.7 & 7.5 & 6.9 & 7.8 & 7.5 & 9.5 & 8.7 & 8.0 & 9.8 \\ \text { SU } & 9.0 & 9.0 & 8.4 & 7.9 & 9.1 & 7.6 & 7.8 & 8.0 & 8.3 & 7.8 \\ \text { UmU } & 9.0 & 10.4 & 10.6 & 10.2 & 8.4 & 7.9 & 9.3 & 10.4 & 12.0 & 11.7 \\ \text { UU } & 8.7 & 8.1 & 8.4 & 12.7 & 11.2 & 10.6 & 7.9 & 8.6 & 9.6 & 13.2\end{array}$

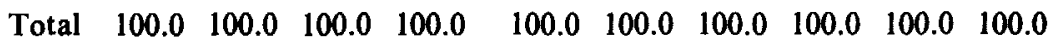

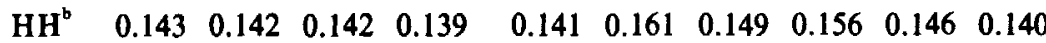

Source: Accounting records of the various units. The figures for the Stockholm School of Economics have been estimated, as the School follows rules of its own for the allocation of resources to basic research.

Notes: - Estimated figure

- Estimated figure 


\section{Introduction and background studies}

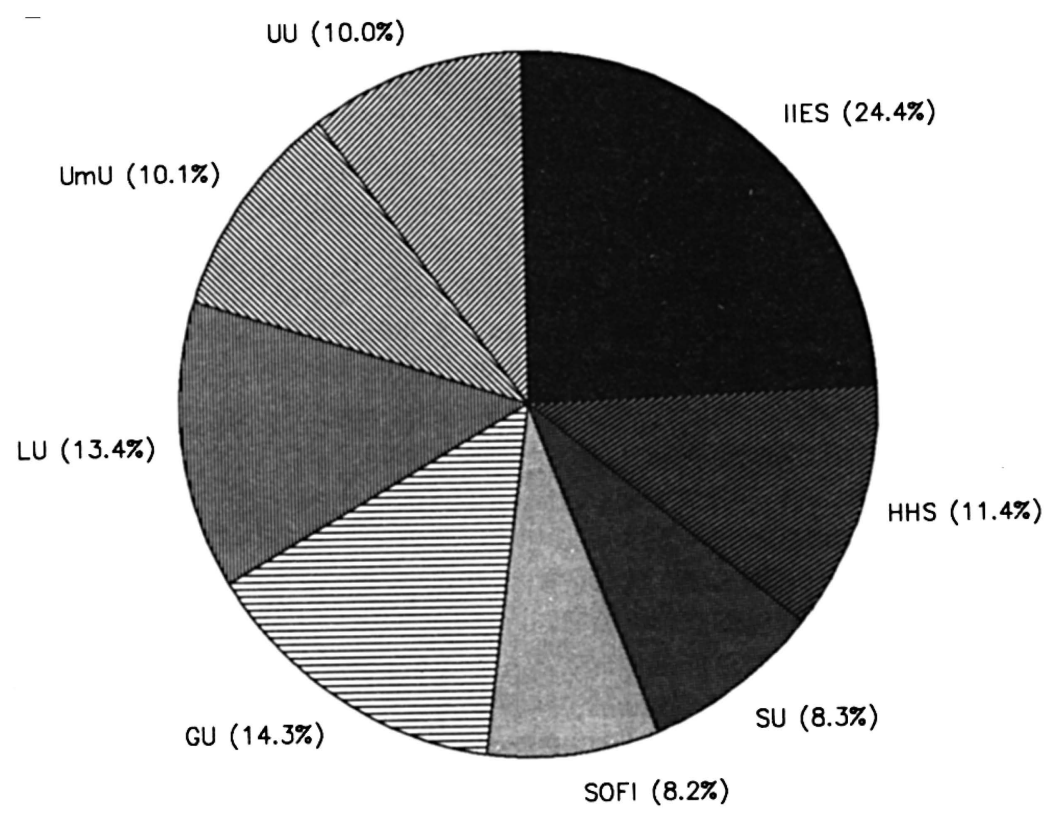

Figure 3.1 Distribution of faculty grants $1980-1$ to $1989-90$ (1989-90 prices)

1 IIES, which received one-fourth,

2 Gothenburg and Lund receiving around one-seventh, and

3 the rest (HHS, SOFI, Stockholm, Umeå and Uppsala) receiving around one-tenth each. ${ }^{22}$

This distribution remained relatively constant throughout the period, as did the degree of concentration. This last, measured by Herfindahl's index, thus varied between a low of 0.139 in 1983-4 and a high of 0.161 in $1985-6 .{ }^{23}$ The values at the beginning and end of the period, and for the period as a whole, were about the same: $0.143,0.140$ and 0.144 respectively.

Figure 3.1 also shows that the four Stockholm units (the Department of Economics, HHS, IIES and SOFI) together received more than half the total faculty grants. This could be expected to have had a positive effect on research output in the region, something which should be kept in mind in interpreting the results in Chapters 4 and 5 .

\section{Resources to economics in relative terms}

In order to understand fully the changes in the faculty grants allocated to economics, it is also important to consider changes in other 
Table 3.2 Faculty grants to economics and all social sciences in 1980-1 to $1989-90$ at $1989-90$ prices (KSEK)

\begin{tabular}{lccc}
\hline $\begin{array}{l}\text { Academic } \\
\text { year }\end{array}$ & Economics & $\begin{array}{c}\text { All social } \\
\text { sciences }\end{array}$ & $\begin{array}{c}\text { Economics/ } \\
\text { Social sciences (\%) }\end{array}$ \\
\hline $1980 / 81$ & 18,290 & 226,714 & 8.1 \\
$1981 / 82$ & 18,428 & 238,305 & 7.7 \\
$1982 / 83$ & 18,594 & 232,522 & 8.0 \\
$1983 / 84$ & 18,141 & 275,505 & 6.6 \\
$1984 / 85$ & 18,869 & 260,520 & 7.2 \\
$1985 / 86$ & 19,886 & 310,503 & 6.4 \\
$1986 / 87$ & 19,427 & 310,964 & 6.2 \\
$1987 / 88$ & 21,970 & 351,018 & 6.3 \\
$1988 / 89$ & 24,358 & 369,722 & 6.6 \\
$1989 / 90$ & 25,493 & 379,443 & 6.7 \\
\hline
\end{tabular}

Source: UHÄ Report 1980:16, 1981:18, 1982:17, 1983:8, 1984:10, 1985:5, 1986:15,

1988:9, 1989:7, 1990:3, and 1991:11. The Stockholm School of Economics is not included in the figures for economics, since it does not receive resources from the faculty grants.

variables. For instance it is interesting to compare the economics grants with the grants made to all the social sciences (table 3.2). This comparison indicates that the relative position of economics has gradually been declining. From a level of 8.1 per cent of the total faculty grants at the beginning of the 1980 s, the economics share had fallen to 6.7 per cent in 1989-90. A probable explanation is that new areas of research had been added to the social science faculties, and that the university concept was extended during the period. Teachers' training colleges and schools of social studies, formerly independent, were merged with the universities, bringing a certain amount of fixed research resources with them. The base for the faculty grants thus became broader, and the denominator in the ratio between research resources for economic research and other social science research increased.

The indication that a shift in the system appears to have taken place in the early 1980s is confirmed by a comparison of the changes in economics faculty grants with the grants to higher education and research as a whole, on the one hand, and with Swedish GNP on the other (table 3.3). This comparison shows that the relationship between economics and total grants has shifted from 0.23 per cent to around 0.17 per cent. This development is parallel to a shift in the other direction for the ratio between total grants and GNP, from a level of 0.75 per cent in the early 1980 s to round 1.0 per cent from 1982-3. 


\section{Introduction and background studies}

Table 3.3 Relationship between total faculty grants, economics faculty grants and gross national product

\begin{tabular}{|c|c|c|c|c|c|c|}
\hline \multirow[t]{2}{*}{ Year } & \multicolumn{2}{|c|}{$\begin{array}{c}\text { Faculty } \\
\text { grants }\end{array}$} & \multirow{2}{*}{$\begin{array}{r}G N P \\
(1,000 \\
M S E K)\end{array}$} & \multirow{2}{*}{$\begin{array}{r}\text { Econo- } \\
\text { nomics } / \\
\text { Total } \\
\text { grants } \\
(\%)\end{array}$} & \multirow{2}{*}{$\begin{array}{r}\text { Total } \\
\text { grants } / \\
\text { GNP } \\
(\%)\end{array}$} & \multirow{2}{*}{$\begin{array}{r}\text { Econo- } \\
\text { nomics/ } \\
G N P \\
(p r o \\
\text { mille) }\end{array}$} \\
\hline & $\begin{array}{c}\text { Econo- } \\
\text { mics } \\
M S E K\end{array}$ & $\begin{array}{r}\text { Total } \\
(1,000 \\
M S E K)\end{array}$ & & & & \\
\hline $1980 / 81$ & 9,780 & 4,173 & 553,584 & 0.23 & 0.75 & 0.0177 \\
\hline $1981 / 82$ & 10,530 & 4,631 & 606,297 & 0.23 & 0.76 & 0.0174 \\
\hline $1982 / 83$ & 11,407 & 6,759 & 671,767 & 0.17 & 1.01 & 0.0170 \\
\hline $1983 / 84$ & 11,857 & 7,298 & 752,075 & 0.16 & 0.97 & 0.0158 \\
\hline $1984 / 85$ & 12,925 & 7,763 & 830.043 & 0.17 & 0.94 & 0.0156 \\
\hline $1985 / 86$ & 14,515 & 8,731 & 905,986 & 0.17 & 0.96 & 0.0160 \\
\hline $1986 / 87$ & 15,059 & 9,556 & 983,535 & 0.16 & 0.97 & 0.0153 \\
\hline $1987 / 88$ & 18,008 & 10,943 & $1,067,426$ & 0.16 & 1.03 & 0.0169 \\
\hline $1988 / 89$ & 21,181 & 11,960 & $1,169,135$ & 0.18 & 1.02 & 0.0181 \\
\hline $1989 / 90$ & 25,493 & 13,900 & $1,282,228$ & 0.18 & 1.08 & 0.0199 \\
\hline
\end{tabular}

Source: Statistiska Meddelanden N14SM9001 (1990, table 3, 4 and 6) and table 3.1 above. The Stockholm School of Economics is again excluded from the analysis (cf. above).

The net effect of these two changes has been that the relationship between economics faculty grants and GNP was gradually declining up to 1986-7 and then recovering during the last of the three years studied, such that in 1989-90 the ratio was even higher than in 1980-1, namely 0.0199 as against 0.0177 .

\section{Conclusions}

Our study of faculty grants to economics thus seems to reveal that, at fixed prices, the grants have been fairly constant throughout the period except for the last three years. In comparison with grants to the social sciences as a whole and with total grants to higher education and research, the economics share declined in the early 1980s. However, this appears to be due to the inclusion of new units in the university system rather than to a specific drop in the support for economics. When it came to the distribution of the allocations we found that IIES, by obtaining almost one-quarter of the faculty grants occupied a favourable position. The other units received around 10 per cent each with some variation over the years. Because of the position of IIES and the existence of three other academic units in Stockholm. 
we found that well over half this type of resources was being allocated to economics research in Stockholm.

\section{EXTERNAL RESEARCH GRANTS}

Of the three kinds of external research grants mentioned at the beginning of the chapter - basic research organizations, applied research-financing bodies, and private foundations - we can discuss the first two only in the present study, since private foundations often provide personal scholarships which are not included in the accounting system of the universities. ${ }^{24}$ From the data available it is evident that external research grants play an important part in the different departments. In addition to the SEK 230 million at $1989-90$ prices channelled into university departments for research in the shape of faculty grants, an almost equally large sum - SEK 203 million at 198990 prices - was obtained by making application to various external sources.

Of the SEK 203 million in external grants to the eight units studied, SEK 25 million came from HSFR, out of which SEK 19 million represented project grants and SEK 6 million funds for research positions. The allocation to economics from the Bank of Sweden Tercentenary Foundation was SEK 54 million, all in the form of project grants. ${ }^{25}$ This leaves SEK 124 million, i.e. three-fifths of total external grants, which came from applied research-financing bodies. ${ }^{26}$ It is not unreasonable to assume that this structure of the financial sources for economic research in Sweden has made a considerable impact on the composition of the research agenda.

As can be seen from figure 3.2 the distribution of this type of funding between the different university cities has not been as stable as in the case of the faculty grants, which is a natural result of the cycles of research programmes. If we try to identify trends, we can note a positive development particularly for Gothenburg, with an increase from 5.2 per cent in 1983-4 to 34.1 per cent in 1989-90. Uppsala has also experienced a similar although less spectacular trend in recent years, from 1.4 per cent in 1986-7 to 6.2 per cent in 1989-90. Negative trends can be observed for Lund since 1986-7, from 21.1 per cent to 10.4 per cent, and for the four Stockholm units (the department at the University, IIES, SOFI and the Stockholm School of Economics) from 70.6 per cent in 1982-3 to 42.3 per cent in 1989-90. Nevertheless more than half ( 56.4 per cent) of the external grants have gone to the latter four units (figure 3.3).

As we move on to analyse the distribution of funding between the 


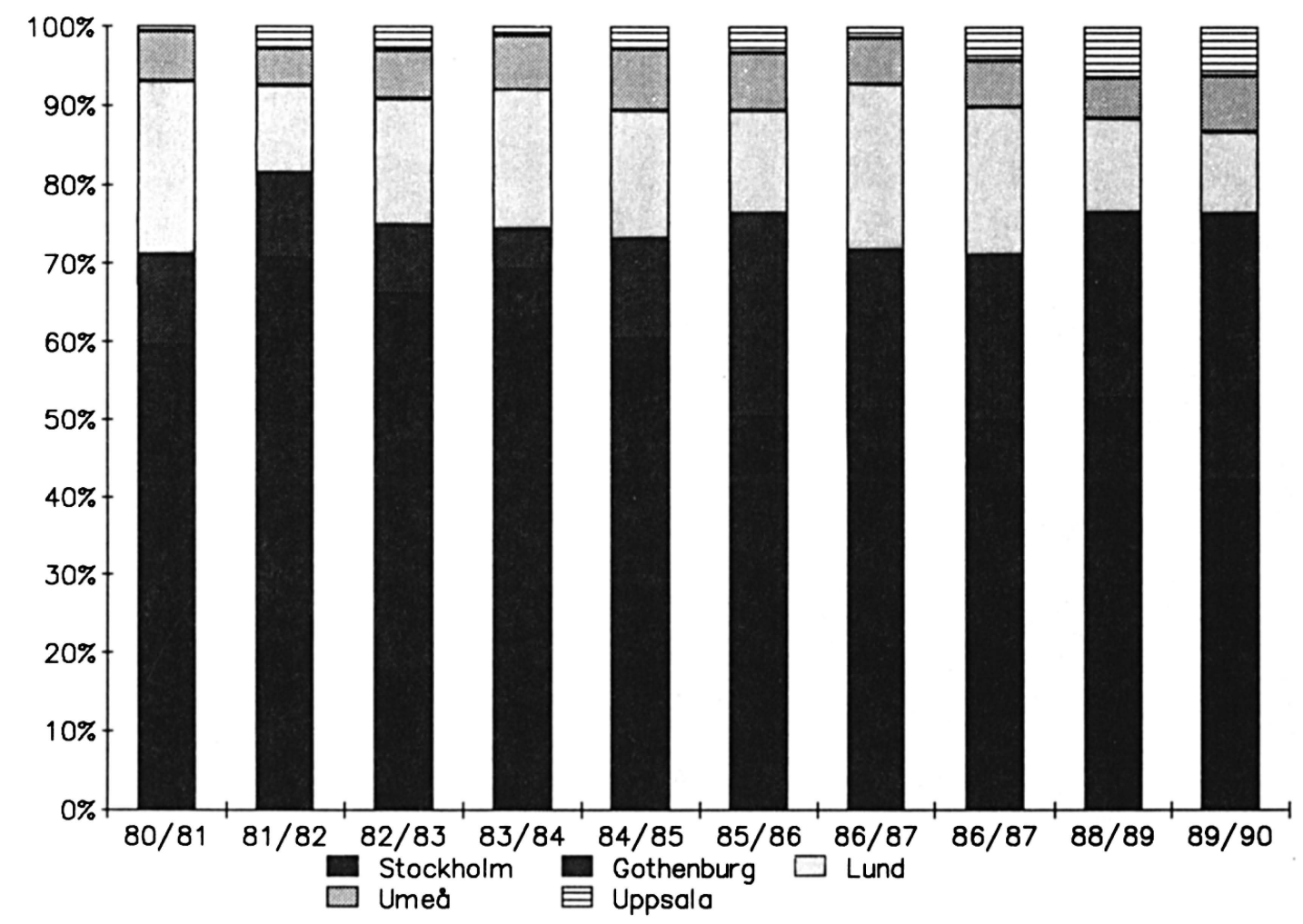

Figure 3.2 Distribution of external grants between university cities 1980-1 to 1989-90 


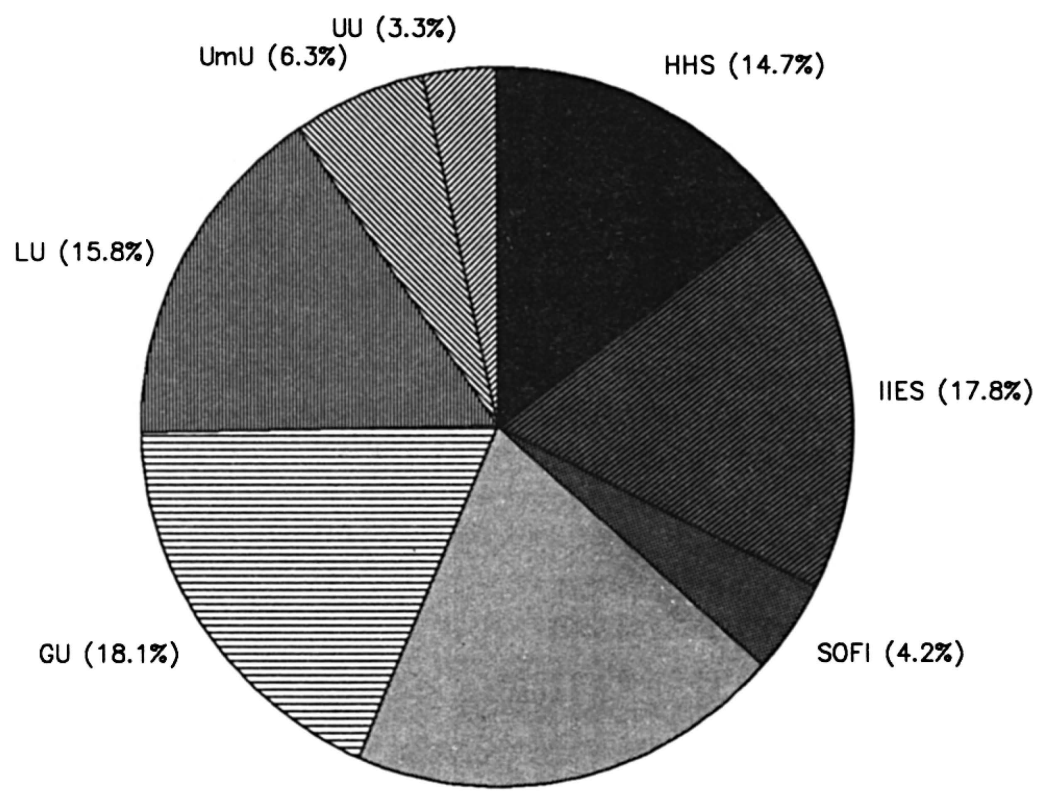

SU (19.7\%)

Figure 3.3 Distribution of external grants 1980-1 to 1989-90 (1989-90 prices)

different units, we find that Gothenburg, HHS, IIES, Lund and Stockholm have received about 15-20 per cent each and that SOFI, Umeå and Uppsala received 14 per cent together (figure 3.3). This means that Gothenburg, HHS and Lund have received a share slightly above their share of faculty grants, while Stockholm received a considerably larger share. IIES, Umeå and Uppsala have all received shares smaller than their corresponding shares of the faculty grants. In the case of Umeå and Uppsala this state of affairs may be explained by their enjoying the closest affiliations with the research institutes of the Federation of Industry (IUI) and the Trade Union Confederation (FIEF), which could mean that some of the research in these economics departments received funding without there being any record of it in the university accounting system.

As regards developments over time (cf. table 3.4), we find that the annual total sum has more or less doubled from SEK 10.9 million in 1980-1 to SEK 20.9 million in 1989-90. At 1989-90 prices, the allocations to economics in $1980-1$ and $1989-90$ were at the same level.

As shown in figure 3.2 there is less stability over time in the external grants than in the faculty grants. We can also note that the degree 


\section{Introduction and background studies}

of concentration, again measured by Herfindahl's index, was higher on the external side: it varied between 0.152 in 1987-8 and 0.204 in 1980-1. A slight downward trend, i.e. a decreasing degree of concentration, can be observed up to 1987-8. The allocation of the grants over time means that the concentration of external grants during the period is above that of the faculty grants: 0.157 as compared with 0.144 .

All in all it is evident from this analysis that external research grants are as important to the financing of Swedish economic research as are the faculty grants. When it comes to the geographical distribution of resources, we have noted a certain concentration to Stockholm. This tendency would be even stronger if the various economics research institutes, which have been excluded from the present study, had also been considered. Of the external grants, applied research financing, with its often more or less 'commissioned' character, proved to be playing a significant role. This in turn can be expected to have affected research orientations among Swedish economists.

\section{TOTAL RESOURCES TO ECONOMICS RESEARCH}

As we now turn to an analysis of the total resources allocated to economics research, it should be pointed out once more that it has not been possible to include grants from private foundations. ${ }^{27}$ Nor has it been possible to consider research appointments at institutes outside the universities. Thus the figures given here will underestimate the total resources actually provided.

The total resources received by the eight units studied at 1989-90 prices (table 3.5), amounted to SEK 433 million, i.e. an average of SEK 43 million per year. At fixed prices the resources received were fairly stable throughout the period except for some slight growth towards the end. Total annual resources thus increased in 1989-90 by about 20 per cent compared with the 1980-1 level, i.e. from SEK 41.2 million to SEK 49.4 million.

But the total resources allocated to economics research would be seen to have increased much more, if allocations of new research resources outside the universities had been included. The most significant example of this type of source is the Trade Union Institute for Economic Research (founded in 1985) ${ }^{28}$

Turning to the distribution of total grants among university units (figure 3.4), we again find three groups: 
The economics of Swedish economics 63

Table 3.4 External financing of economics research 1980-1 to 1989-90 (KSEK)

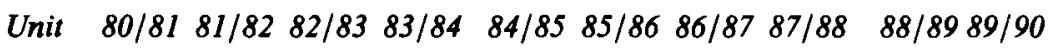

Current prices:

$\begin{array}{lrrrrrrrrrr}\text { GU } & 1,282 & 1,082 & 844 & 660 & 1,748 & 4,145 & 3,530 & 3,824 & 4,876 & 7,147 \\ \text { HHS } & 2,040 & 1,830 & 2,509 & 2,540 & 1,821 & 1,955 & 1,966 & 1,986 & 2,395 & 1,909 \\ \text { IIES } & 1,108 & 2,180 & 1,270 & 2,346 & 3,120 & 3,297 & 1,484 & 2,403 & 5,609 & 4,315 \\ \text { LU } & 2,417 & 1,109 & 1,553 & 2,245 & 2,222 & 2,061 & 3,627 & 3,344 & 2,422 & 2,170 \\ \text { SOFI } & 0 & 16 & 564 & 642 & 261 & 395 & 2,077 & 1,442 & 468 & 753 \\ \text { SU } & 3,344 & 3,050 & 2,061 & 3,341 & 3,026 & 2,358 & 3,280 & 3,027 & 2,252 & 1,869 \\ \text { UmU } & 692 & 471 & 595 & 886 & 1,050 & 1,166 & 1,000 & 1,033 & 1,066 & 1,479 \\ \text { UU } & 70 & 285 & 294 & 148 & 393 & 525 & 238 & 765 & 1,300 & 1,289\end{array}$

Total $10,95310,023 \quad 9,69012,808 \quad 13,641 \quad 15,902 \quad 17,202 \quad 17,824 \quad 20,388 \quad 20,931$

Fixed prices $1989 / 90$ price level

$\begin{array}{lrrrrrrrrrr}\text { GU } & 2,397 & 1,894 & 1,376 & 1,010 & 2,552 & 5,679 & 4,554 & 4,665 & 5,607 & 7,147 \\ \text { HHS } & 3,815 & 3,203 & 4,090 & 3,886 & 2,659 & 2,678 & 2,536 & 2,423 & 2,754 & 1,909 \\ \text { IIES } & 2,072 & 3,815 & 2,070 & 3,589 & 4,555 & 4,517 & 1,914 & 2,932 & 6,450 & 4,315 \\ \text { LU } & 4,520 & 1,941 & 2,531 & 3,435 & 3,244 & 2,824 & 4,679 & 4,080 & 2,785 & 2,170 \\ \text { SOFI } & 0 & 28 & 919 & 982 & 381 & 541 & 2,679 & 1,759 & 538 & 753 \\ \text { SU } & 6,253 & 5,338 & 3,359 & 5,112 & 4,418 & 3,230 & 4,231 & 3,693 & 2,590 & 1,869 \\ \text { UmU } & 1,294 & 824 & 970 & 1,356 & 1,533 & 1,597 & 1,290 & 1,260 & 1,226 & 1,479 \\ \text { UU } & 131 & 499 & 479 & 226 & 574 & 719 & 307 & 933 & 1,495 & 1,289\end{array}$

Total $20,48217,54215,79419,596 \quad 19,91621,78522,19021,745 \quad 23,44520,931$

Relative shares of departments (\%)

$\begin{array}{lrrrrrrrrrr}\text { GU } & 11.7 & 10.8 & 8.7 & 5.2 & 12.8 & 26.1 & 20.5 & 21.4 & 23.9 & 34.1 \\ \text { HHS } & 18.6 & 18.3 & 25.9 & 19.8 & 13.3 & 12.3 & 11.4 & 11.1 & 11.8 & 9.1 \\ \text { IIES } & 10.1 & 21.7 & 13.1 & 18.3 & 22.9 & 20.7 & 8.6 & 13.5 & 27.5 & 20.6 \\ \text { LU } & 22.1 & 11.1 & 16.0 & 17.5 & 16.3 & 13.0 & 21.1 & 18.8 & 11.9 & 10.4 \\ \text { SOFI } & 0.0 & 0.2 & 5.8 & 5.0 & 1.9 & 2.5 & 12.1 & 8.1 & 2.3 & 3.6 \\ \text { SU } & 30.5 & 30.4 & 21.3 & 26.1 & 22.2 & 14.8 & 19.1 & 17.0 & 11.0 & 8.9 \\ \text { UmU } & 6.3 & 4.7 & 6.2 & 6.9 & 7.7 & 7.3 & 5.8 & 5.8 & 5.2 & 7.1 \\ \text { UU } & 0.7 & 2.8 & 3.0 & 1.2 & 2.9 & 3.3 & 1.4 & 4.3 & 6.4 & 6.2\end{array}$

$\begin{array}{lllllllllll}\text { Total } & 100.0 & 100.0 & 100.0 & 100.0 & 100.0 & 100.0 & 100.0 & 100.0 & 100.0 & 100.0\end{array}$ $\begin{array}{lllllllllll}\text { HH }^{\text {b }} & 0.204 & 0.199 & 0.171 & 0.181 & 0.169 & 0.171 & 0.161 & 0.152 & 0.180 & 0.195\end{array}$

Source: Accounting records in the different units.

Notes: "Estimated figure

- Concentration measured by Herfindahl's index. 


\section{Introduction and background studies}

Table 3.5 Total financing of economics research 1980-1 to 1989-90 (KSEK)

$\begin{array}{llllllllll}\text { Unit } \quad 80 / 81 & 81 / 82 & 82 / 83 & 83 / 84 & 84 / 85 & 85 / 86 & 86 / 87 & 87 / 88 & 88 / 89 & 89 / 90\end{array}$

\begin{tabular}{lrrrrrrrrrr}
\hline \multicolumn{1}{l}{ Current prices } & & & & & & & & \\
GU & 3,082 & 2,932 & 2,749 & 2,577 & 3,768 & 6,108 & 5,840 & 6,614 & 8,274 & 11,442 \\
HHS & 3,350 & 3,206 & 4,039 & 4,198 & 3,516 & 3,739 & 4,200 & 3,981 & 5,053 & 4,904 \\
IIES & 3,687 & 4,859 & 4,091 & 5,205 & $6,403^{2}$ & 8,109 & 6,000 & 8,075 & 11,624 & 10,781 \\
LU & 3,942 & 2,919 & 3,730 & 4,229 & 4,512 & 4,341 & 5,906 & 5,745 & 5,152 & 4,782 \\
SOFI & 918 & 939 & 1,535 & 1,573 & 1,399 & 1,605 & 3,719 & 3,175 & 2,383 & 3,540 \\
SU & 4,347 & 4,121 & 3,142 & 4,411 & 4,357 & 3,595 & 4,627 & 4,623 & 4,227 & 4,100 \\
UmU & 1,685 & 1,709 & 1,963 & 2,270 & 2,282 & 2,450 & 2,603 & 3,123 & $3,931^{2}$ & 4,829 \\
UU & 1,032 & 1,244 & 1,378 & 1,860 & 2,024 & 2,254 & 1,600 & 2,491 & 3,583 & 5,051
\end{tabular}

Total $22,04321,92922,62726,32328,261 \quad 32,20134,49537,82744,22749,419$

Fixed prices $1989 / 90$ price level

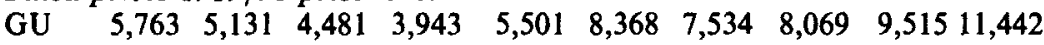

$\begin{array}{lllllllllll}\text { HHS } & 6,265 & 5,611 & 6,584 & 6,423 & 5,133 & 5,122 & 5,418 & 4,857 & 5,811 & 4,904\end{array}$

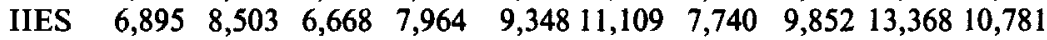

$\begin{array}{lllllllllll}\text { LU } & 7,372 & 5,108 & 6,080 & 6,470 & 6,588 & 5,947 & 7,619 & 7,009 & 5,925 & 4,782\end{array}$

$\begin{array}{lllllllllll}\text { SOFI } & 1,717 & 1,643 & 2,502 & 2,407 & 2,043 & 2,199 & 4,798 & 3,874 & 2,740 & 3,540\end{array}$

$\begin{array}{lllllllllll}\text { SU } & 8,129 & 7,212 & 5,121 & 6,749 & 6,361 & 4,925 & 5,969 & 5,640 & 4,861 & 4,100\end{array}$

$\begin{array}{lllllllllll}\text { UmU } & 3,151 & 2,991 & 3,200 & 3,473 & 3,332 & 3,357 & 3,358 & 3,810 & 4,521 & 4,829\end{array}$

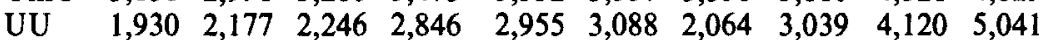

Total $41,22238,37636,88240,27541,26144,11544,50046,15050,86149,419$

Relative shares of departments (\%)

$\begin{array}{lllllllllll}\text { GU } & 14.0 & 13.4 & 12.1 & 9.8 & 13.3 & 19.0 & 16.9 & 17.5 & 18.7 & 23.1\end{array}$

$\begin{array}{lllllllllll}\text { HHS } & 15.2 & 14.6 & 17.9 & 15.9 & 12.4 & 11.6 & 12.2 & 10.5 & 11.4 & 9.9\end{array}$

$\begin{array}{lllllllllll}\text { IIES } & 16.7 & 22.2 & 18.1 & 19.8 & 22.7 & 25.2 & 17.4 & 21.3 & 26.3 & 21.8\end{array}$

$\begin{array}{lllllllllll}\text { LU } & 17.9 & 13.3 & 16.5 & 16.1 & 16.0 & 13.5 & 17.1 & 15.2 & 11.6 & 9.7\end{array}$

$\begin{array}{lrrrrrrrrrr}\text { SOFI } & 4.2 & 4.3 & 6.8 & 6.0 & 5.0 & 5.0 & 10.8 & 8.4 & 5.4 & 7.2\end{array}$

$\begin{array}{lllllllllll}\text { SU } & 19.7 & 18.8 & 13.9 & 16.8 & 15.4 & 11.2 & 13.4 & 12.2 & 9.6 & 8.3\end{array}$

$\begin{array}{lllllllllll}\mathrm{UmU} & 7.6 & 7.8 & 8.7 & 8.6 & 8.1 & 7.6 & 7.5 & 8.3 & 8.9 & 9.8\end{array}$

$\begin{array}{lllllllllll}\text { UU } & 4.7 & 5.7 & 6.0 & 7.1 & 7.2 & 7.0 & 4.6 & 6.6 & 8.1 & 10.2\end{array}$

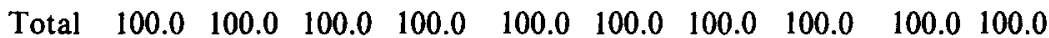

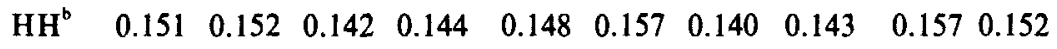

Source: Accounting records at the different units.

Notes: :Partly based on an estimated figure (cf. above).

' Concentration measured by Herfindahl's index.

1 the IIES, accounting for one-fifth,

2 the economics departments at the HHS, Gothenburg, Lund and Stockholm, with roughly one-seventh each, and 
UU (6.8\%)

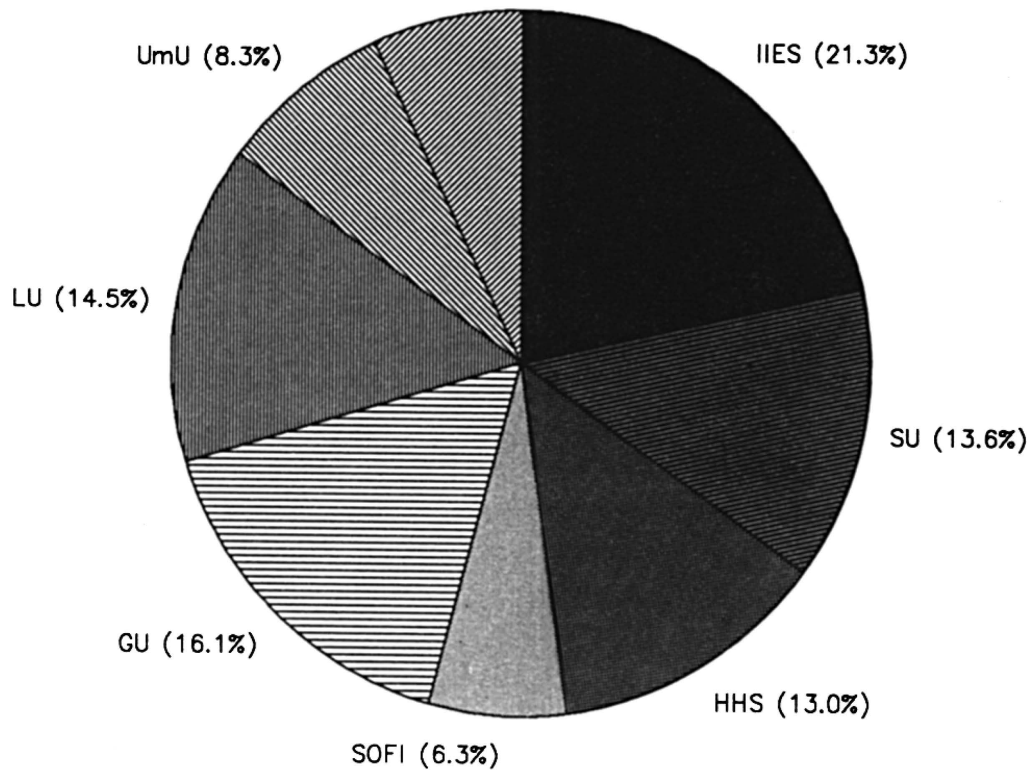

Figure 3.4 Distribution of total research grants 1980-1 to 1989-90 (1989-90 prices)

3 SOFI, Umeå and Uppsala, all receiving less than one-tenth each.

The value of Herfindahl's index is 0.143 , i.e. about the same as for the faculty grants. Over the years this index has remained fairly stable, with a minimum of 0.140 in 1986-7 and a maximum of 0.157 in 1988-9. No trend can be identified. The variation over time at the different units has followed the same patterns that we noted in the case of the external grants (cf. above).

Our analysis has revealed that, at 1989-90 prices, around SEK 433 million were allocated to economics research in the eight units studied during the period 1980-1 - 1989-90. If we allow for resources in research institutes or other research-oriented organizations, and grants not channelled through the university accounting systems, it would not be unreasonable to suggest a total sum well over SEK 500 million. $^{29}$

\section{CONCLUSIONS}

The present chapter has been devoted to an analysis of the resources allocated to economics research in Sweden during the 1980s. In 


\section{Introduction and background studies}

comparing the economics faculty grants with those given to the social sciences as a whole, we identified a shift unfavourable to economics during the early 1980s. Further analysis has shown, however, that this was mainly an effect of structural change in the Swedish university system, i.e. the integration into the universities of certain previously external units, rather than of any systematic decline in the relative status of economics. The relation between faculty grants to economics and GNP has also remained fairly constant throughout the period; it was somewhat higher in 1989-90 than in 1980-1. Altogether these grants amounted to SEK 230 million at 1989-90 prices.

However, the faculty grants represent one element only in the financing of research. An equally important element is represented by the funds provided by various other grant-allocating bodies. At 198990 prices these sources provided SEK 203 million to the eight units studied. Of the external research grants, allocations to applied research which impose more restrictions on the selection of problems, have dominated. They account for three-fifths of total external resources. Needless to say, this has probably affected the orientation of Swedish economics research in the 1980s.

As regards the allocation of resources to the different units we found a certain, albeit relatively constant, concentration. This applies to the faculty grants, of which almost one-quarter went to IIES, while the other units received roughly one-tenth each. Of the external grants, 15-20 per cent was allocated to each of the studied institutions except SOFI and the Economics departments at Umeå and Uppsala. Altogether we thus find that IIES has received about one-fifth of the total; the economics departments at HHS, Gothenburg, Lund and Stockholm about one-seventh each; and SOFI, Umeå and Uppsala less than one-tenth each. The presence of several units in the Stockholm area - the Economics Department at Stockholm University, IIES, SOFI and the Stockholm School of Economics - has meant that well over half of the overall resources were allocated to the nation's capital. This tendency is further reinforced by the fact that several research institutes outside the university system are located in Stockholm. Such a state of affairs is not necessarily inappropriate, but it should be kept in mind when the output of Swedish economics in terms of doctoral theses and publications are analysed in the following two chapters. 


\title{
4 Recruiting a new generation
}

\author{
Eskil Wadensjö
}

\section{INTRODUCTION}

The recruitment of a new generation of economists, i.e. economists who have completed their Ph.D. degrees, is crucial for both research and education in economics. Most economists in Sweden have received the main part of their postgraduate training here and only a few acquire a Ph.D. abroad. 'The new generations of economists will probably still receive most of their training in Sweden. The education of doctors of economics at the Swedish universities is crucial to the recruitment of economists in the country.

Three problems concerning the training of research students have been the subject of debate for decades (cf. e.g. Zetterblom 1989):

1 the number of participants in Ph.D. studies is low, and the number of completed Ph.D. degrees is particularly so;

2 the average time necessary to complete a Ph.D. is long and getting longer; and

3 the age of those defending their Ph.D. theses is high, partly because of the lengthy period of study, and partly because many start studying for a $\mathbf{P h}$.D. late.

Other issues have also been discussed, such as the quality of the theses, the language in which they are written, and in later years the low proportion of women Ph.D. students (cf. e.g. SOU 1981:29: 108-11). Most of these problems are common to the social sciences and the humanities, and possibly to other disciplines too. The purpose of the present chapter is to analyse these issues as they pertain to economics. 


\section{Introduction and background studies}

\section{THE SWEDISH SYSTEM OF POSTGRADUATE EDUCATION}

Theses

Theses are a very important part of research at Swedish universities. First, they form a crucial part of the training of new researchers. Second, in many disciplines the theses themselves are an essential part of the research that is being done. This may apply less to economics than to the humanities, for example, but probably more than to the natural sciences. Third, the theses have long-term consequences. Most researchers continue their scientific work in an area fairly close to the subject of their theses. There are long-term effects in the training of researchers in this respect. Fourthly, theses are major events in the academic life of most departments, around which much of the research activity revolves. Most people presenting $\mathrm{Ph} . \mathrm{D}$. theses are no longer students, but are members of the departmental staff. In many cases they have been so for several years prior to defending their theses.

There are currently two research degrees in the Swedish university system. The lower is the licentiate degree (licentiatexamen) and the higher the doctoral degree (doktorsexamen). For most of this century (and even during the later decades of the nineteenth century) Sweden has had this two-tier system. However, the system has undergone one major change. The present Ph.D. degree (doktorsexamen) is not the same as the one obtained before the change (doktorsgrad). The licentiate degree disappeared for a period of more than ten years, only to reappear in a new form. To avoid confusion we will discuss four different degrees (and theses): the old Ph.D., the new Ph.D., the old licentiate and the new licentiate. A list of all Swedish Ph.D. theses in economics from 1895 to 1989 is given in Appendix D.

\section{The old Ph.D. system}

The system for training and examining of researchers was basically the same for almost a hundred years, from the 1870s to the end of the 1960s. After acquiring an undergraduate degree, it was possible to continue studying for the licentiate exam. The main teaching method consisted of regular seminars to discuss papers presented by research students and others. For a licentiate a written thesis as well as an oral examination was required. The thesis did not have to be defended in public, but it had to be available to all those interested in reading it three weeks before it was graded by the professor. The grade and the degree were confirmed by the faculty. In some cases the old licentiate 
thesis consisted of chapters intended for inclusion in a future Ph.D. thesis. In most cases, however, the old licentiate thesis was not developed in this way, nor was this probably the intention of the student in the majority of such cases. Of the 226 who have received an old licentiate degree in economics since the beginning of this century, only 66 later obtained a Ph.D. in economics, ${ }^{2}$ and this was on an average 5.7 years after having received the licentiate degree. ${ }^{3}$ A further group of 29 obtained a new Ph.D. Those in this second group all received their licentiate degrees at the end of the $1960 \mathrm{~s}$ or the beginning of the 1970s.

A Ph.D. thesis according to the old order was a serious matter. Contributions to economic theory were expected of any thesis in economics. An old Ph.D. thesis had to be published and defended in public. As there were very few Ph.D. theses forthcoming, the audience was generally large and interested. The faculty appointed the first opponent, and the author the second one. Extra (in many cases well prepared) opponents were not uncommon. ${ }^{4}$ Until the post war period the opponent appointed by the faculty was generally chosen from the same university, a docent (rather like associate professor without tenure) or a professor. According to the regulations a docent was obliged to agree to act as opponent in his own faculty. Gradually, however, it became more and more common to choose an opponent who was not a faculty member at the same university.

The grade for the thesis was determined by the faculty on the recommendation of a special committee. As was mentioned in Chapter 2, the grade was very important: if it was above a specific level, the $\mathrm{Ph}$.D. recipient was granted the title of docent, which made it possible to continue an academic career. Otherwise it was much more difficult to remain at the university. ${ }^{5}$ Under the old system no thesis in economics presented for public defence ever failed to pass. In one case in the 1940s, however, it was very close. The faculty was very critical and the thesis was given the lowest possible mark (B).

The number of Ph.D. and licentiate degrees increased in the postwar period, but the number of Ph.D. degrees in particular was still very low. Less than two Ph.D. degrees a year was the average in economics at this time. The majority of those taking a licentiate degree did not go on to write a Ph.D. thesis on the old model. Even among those who continued to pursue an academic career, several never presented a Ph.D. thesis. The age of those presenting theses was tending to rise. The average age of those acquiring a licentiate degree in the social sciences in 1963 was 34.2 years, and for those acquiring an old Ph.D. in social sciences and humanities, 39.5 (SOU 1966:68: 163). 


\section{Introduction and background studies}

\section{The new Ph.D. system}

The small number of $\mathrm{Ph} . \mathrm{D}$. degrees and the high (and rising) age of those receiving the old Ph.D. or licentiate degree were two of the problems facing a government committee appointed in 1963. The committee proposed a radical restructuring of the Swedish system for training researchers (SOU 1966: 67). The proposal was modelled mainly on the American system. The two earlier degrees were replaced by a new Ph.D. To acquire this degree the student not only had to present and defend a thesis but also had to complete a course programme. The total period of study for the new Ph.D. was supposed to be 4 years, of which $2-2 \frac{1}{2}$ years were reserved for writing a thesis. It was expected that on an average the new doctors would be 28 years old.

The new Ph.D. had to be duplicated in some way but not necessarily published, as had been the rule for the old Ph.D. The student was to be reimbursed for the whole printing cost up to 160 pages. For pages over this limit no support would be given. According to the old system printing support for a Ph.D. thesis was a fixed percentage of the total cost up to 320 pages. These changes were made in order to shorten the time required for preparing a thesis. The government committee recommended that more theses should take the form of collections of previously published articles with a summary (sammanläggningsavhandling).

An opponent appointed by the faculty was to examine the thesis critically and in public, in much the same way as before. The government committee was in favour of choosing an opponent from outside the Ph.D. candidate's own university, but suggested that this could not be made compulsory since some disciplines in Sweden, especially in the humanities, have departments at one university only. This suggestion was adopted.

There were now only two grades: pass and fail. This was intended to act as a major impetus towards shortening the time needed to complete a thesis. The grade was determined by an examiner, generally the same person who had been the student's adviser.

The new rules came into force from 1 July 1969. However, it was possible for students already registered as doctoral students to continue under the old system for a few more years. The last Ph.D. in economics of the old type was awarded in 1973 and the last licentiate degree in 1974. In both cases the degrees were awarded at the Stockholm School of Economics, whose system is slightly different from that of the state universities.

Since 1969 the system has been changed in a series of small steps 
back towards the old type of system. A controversial thesis in educational psychology at Stockholm University was one of the factors which led to a change in the rule whereby the examiner/adviser determined the grade. Since 1 July 1974 grades are decided by a committee of three or five members. The adviser could still be a member of the committee. Another much discussed thesis, this time in sociology at Lund University, led to a further revision in the rules. From 1 July 1984 advisers have been excluded from the examination committee (apart from a few specific cases of no relevance to economics). A majority on the committee must come from departments other than that of the Ph.D. student, and at least one member should be from another faculty or university. The committee generally consists of one economist from the candidate's department, one non-economist from the same faculty, and one economist from another university.

Another change concerns the rules for printing grants. As we have seen, this contribution was originally paid for the first 160 pages only. Now there is no such limit. The justification for this change was that many people circumvented the limit by finding additional printing support from other sources, and that in practice the system discriminated against those without extra resources. But it was not mandatory on the faculties. In some cases they continued to follow the old rules. More recently there has been a trend towards fixed printing grants, the same for everybody.

The licentiate degree was reintroduced in the 1980s. It was justified both as a step towards a Ph.D., making the final step less dramatic, and as a way of making it easier to leave the university without a Ph.D. but still with a research degree. It was optional for faculties and departments to introduce the new licentiate degree. It has gradually been returning since 1985 in economics, and it is now possible to acquire the new licentiate degree in economics at all Swedish universities.

According to the statutes the new licentiate should take two years. Part of the time is to be spent writing a thesis and part of it for course work (part of the Ph.D. programme). The licentiate thesis has to be defended in public; the faculty appoints the opponent. The grade (pass/fail) is awarded by an examiner (in general the adviser) or by a committee, which generally includes the adviser and comprises members exclusively from the department.

\section{THE SMALL NUMBER OF THESES}

The three first theses in economics according to the new system were presented in 1970 . Obviously all three candidates and several others 


\section{Introduction and background studies}

Table 4.1 First-time registered postgraduate students in economics 1972-3 to 1989-90

\begin{tabular}{|c|c|c|c|c|c|c|c|c|c|}
\hline \multirow[t]{2}{*}{ Year } & \multicolumn{6}{|c|}{ University $^{\mathrm{a}}$} & \multirow[b]{2}{*}{ Total } & \multirow[b]{2}{*}{ Men } & \multirow[b]{2}{*}{ Women } \\
\hline & $U U$ & $L U$ & $G U^{b}$ & $S U$ & $U m U$ & $H H S$ & & & \\
\hline $1972 / 73$ & 2 & 10 & 11 & 0 & 4 & 3 & 30 & 27 & 3 \\
\hline $1973-4$ & 8 & 10 & 4 & 20 & 3 & 6 & 51 & 45 & 6 \\
\hline $1974-5$ & 6 & 6 & 4 & 15 & 0 & 5 & 36 & 34 & 2 \\
\hline $1975-6$ & 8 & 6 & 3 & 12 & 1 & 3 & 33 & 29 & 4 \\
\hline $1976-7$ & 8 & 3 & 8 & 8 & 0 & 6 & 33 & 32 & 1 \\
\hline $1977-8$ & 9 & 6 & 2 & 5 & 2 & 2 & 26 & 23 & 3 \\
\hline $1978-9$ & 9 & 14 & 4 & 9 & 8 & 3 & 47 & 40 & 7 \\
\hline $1979-80$ & 6 & 10 & 8 & 8 & 4 & 4 & 40 & 37 & 3 \\
\hline $1980-1$ & 7 & 2 & 9 & 7 & 7 & 1 & 33 & 27 & 6 \\
\hline $1981-2$ & 10 & 8 & 7 & 7 & 2 & 5 & 39 & 30 & 9 \\
\hline $1982-3$ & 10 & 9 & 11 & 10 & 4 & 5 & 49 & 40 & 9 \\
\hline $1983-4$ & 0 & 2 & 8 & 8 & 3 & 2 & 23 & 15 & 8 \\
\hline $1984-5$ & 1 & 8 & 5 & 10 & 0 & 8 & 32 & 30 & 2 \\
\hline $1985-6$ & 8 & 8 & 0 & 8 & 1 & 6 & 31 & 23 & 8 \\
\hline $1986-7$ & 3 & 7 & 19 & 7 & 3 & 7 & 46 & 38 & 8 \\
\hline $1987-8$ & 3 & 4 & 15 & 9 & 10 & 3 & 44 & 41 & 3 \\
\hline $1988-9$ & 9 & 6 & 13 & 7 & 7 & 10 & 52 & 35 & 17 \\
\hline $1989-90$ & 12 & 6 & 9 & 9 & 5 & 3 & 44 & 41 & 3 \\
\hline
\end{tabular}

Source: Computations for this chapter from the 'Research Student Register' from Statistics Sweden, Örebro.

Notes: 'UU $=$ Uppsala University, $\mathrm{LU}=$ Lund University, $\mathrm{GU}=$ Gothenburg University, $\mathrm{SU}=$ Stockholm University, $\mathrm{UmU}=$ Umeå University, $\mathrm{HHS}=$ Stockholm School of Economics.

'The figures include those registered as postgraduate students in econometrics at the University of Gothenburg: 11 in 1986-7, 6 in 1987-8, 1 in $1988-9$ and 2 in 1989-90 (University of Gothenburg, Enheten för studiedokumentation).

who obtained the new Ph.D. degree over the next few years had started on their theses under the old system. Altogether 107 people some already holding an old licentiate degree and some registered for it - were transferred to the new system. In the spring term of 1972 there were 174 students registered for Ph.D. studies. Since then the yearly inflow of students has varied between 23 and 52, with no clear tendency to increase or decrease (table 4.1). The number of research students has stabilized at a level of around 220.

By 31 December 1989, 220 people had presented their Ph.D. theses since the new system started in 1969: 203 at universities with general programmes of postgraduate studies in economics and 17 at universities running specialized programmes (agriculture, forestry, health). If we exclude the first few years (1969—73), this means twelve to thirteen 
Recruiting a new generation 73

Table 4.2 Numbers obtaining Ph.D. degrees in economics by year of examination and university

\begin{tabular}{lrrrrrrrr}
\hline \multicolumn{1}{c}{ University } & & & \\
Year & $U U$ & $L U$ & $G U$ & $S U$ UmU & HHS & Other & Total \\
\hline 1970 & 0 & 0 & 1 & 1 & 0 & 2 & 0 & 4 \\
1971 & 0 & 0 & 0 & 1 & 0 & 0 & 1 & 2 \\
1972 & 0 & 2 & 0 & 2 & 1 & 2 & 0 & 6 \\
1973 & 1 & 1 & 0 & 1 & 0 & 1 & 1 & 5 \\
1974 & 1 & 3 & 0 & 0 & 0 & 2 & 1 & 8 \\
1975 & 2 & 1 & 3 & 5 & 0 & 3 & 0 & 14 \\
1976 & 1 & 2 & 7 & 5 & 2 & 2 & 1 & 20 \\
1977 & 0 & 4 & 3 & 2 & 1 & 1 & 0 & 11 \\
1978 & 1 & 2 & 1 & 1 & 1 & 1 & 1 & 8 \\
1979 & 0 & 2 & 3 & 2 & 0 & 3 & 0 & 10 \\
1980 & 0 & 2 & 0 & 1 & 1 & 1 & 0 & 5 \\
1981 & 2 & 3 & 1 & 3 & 2 & 2 & 1 & 14 \\
1982 & 2 & 2 & 3 & 4 & 1 & 2 & 1 & 15 \\
1983 & 0 & 3 & 3 & 3 & 1 & 1 & 1 & 12 \\
1984 & 0 & 2 & 0 & 1 & 0 & 2 & 1 & 6 \\
1985 & 1 & 6 & 0 & 2 & 0 & 4 & 1 & 14 \\
1986 & 4 & 1 & 3 & 4 & 0 & 1 & 1 & 14 \\
1987 & 3 & 4 & 2 & 3 & 0 & 0 & 3 & 15 \\
1988 & 4 & 2 & 8 & 3 & 4 & 1 & 3 & 25 \\
1989 & 2 & 0 & 2 & 1 & 4 & 3 & 0 & 12 \\
& & & & & & & & \\
Total & 24 & 42 & 40 & 45 & 18 & 34 & 17 & 220 \\
\hline
\end{tabular}

Source: The table is compiled from a register made for this study.

Note: "Universities for Agriculture and Forestry (Uppsala and Umeå) and the Department of Health Studies at Linköping University.

theses a year. This is only slightly more than the number of old licentiate degrees granted yearly in the last few years before the reform, but of course many more than the number of $\mathrm{Ph} . \mathrm{D}$. degrees each year under the old system. See tables 4.2 and 4.3.

Table 4.2 also shows the situation at the different universities. The three big universities are Stockholm University (45 theses), Lund University (42) and Gothenburg University (40). The Stockholm School of Economics is in the middle range (34), while Uppsala (24) and Umeå (18) are both smaller. It should be noted, however, that Uppsala and Umeå have produced a relatively large number of theses over the last few years.

Before the reform Stockholm and Lund, in that order, were the two most active universities, while Uppsala came in third place (table 4.4). However, until the post-war period very few Ph.D. degrees were given 


\section{Introduction and background studies}

Table 4.3 Number of theses in economics 1895-1989 by type of degree and decade

\begin{tabular}{lcccc}
\hline Decade & $\begin{array}{c}\text { Old Lic } \\
1902-74\end{array}$ & $\begin{array}{c}\text { Old Ph.D. } \\
\text { 1895-1973 }\end{array}$ & $\begin{array}{c}\text { New Lic. } \\
1985-9\end{array}$ & $\begin{array}{c}\text { New Ph.D } \\
1970-89\end{array}$ \\
\hline $1895-9$ & & 2 & & \\
$1900-9$ & 9 & 4 & & \\
$1910-19$ & 10 & 9 & & \\
$1920-9$ & 27 & 8 & & \\
$1930-9$ & 17 & 8 & & \\
$1940-9$ & 37 & 8 & & \\
$1950-9$ & 36 & 16 & & \\
$1960-9$ & 60 & 19 & & \\
$1970-9$ & 39 & 3 & 43 & 132 \\
$1980-9$ & & & 43 & 220 \\
& 229 & 76 & 43 & \\
\hline
\end{tabular}

Source: The table is compiled from a register made for this study.

in economics, or in most of the other social sciences or the humanities. The exceptions were the subjects which were also taught at the upper secondary school. The general rule was that the head teachers (lektor) in the various subjects should have a Ph.D. in the relevant subject (Dahllöf 1987, 1989). Economics was not taught in the upper secondary schools.

The two business schools (in Gothenburg and Stockholm) did not have the right to give licentiates and doctoral degrees in the first decades dealt with in this study. They were both granted the right to award licentiate degrees in 1943, and in 1946 the Stockholm School of Economics received governmental approval to grant doctoral degrees. The Gothenburg School of Economics obtained the same right in $1950 .^{7}$

A more detailed study reveals that the activity rate varied considerably over time, something which can be largely explained by reference to the retirement and appointment of professors. Between 1921 and 1941, in Uppsala no-one achieved a Ph.D. and only three obtained the licentiate degree, and then only with the lowest grade. ${ }^{8}$ Not surprisingly, in view of the information provided in Chapter 2, we find that Fritz Brock was the only professor in Uppsala during this period. In 1942, the same year that Brock retired, Tord Palander - acting as professor at Uppsala until the new professor (Erik Lindahl) took office - awarded five licentiate degrees.'

Table 4.4 also shows the considerable variation in the number of 
Recruiting a new generation 75

Table 4.4 Theses in economics $1895-1989$ by type of degree and university

\begin{tabular}{|c|c|c|c|c|}
\hline University & $\begin{array}{l}\text { Old Lic. } \\
1902-74\end{array}$ & $\begin{array}{l}\text { Old Ph.D. } \\
1895-1973\end{array}$ & $\begin{array}{c}\text { New Lic. } \\
1985-9\end{array}$ & $\begin{array}{c}\text { New Ph.D. } \\
1970-89\end{array}$ \\
\hline Uppsala & 45 & 14 & 9 & 24 \\
\hline Lund & 63 & 17 & 3 & 42 \\
\hline Gothenburg & 31 & 7 & 4 & 40 \\
\hline Stockholm & 69 & 33 & 5 & 45 \\
\hline Umeå & 3 & 0 & 1 & 18 \\
\hline \multicolumn{5}{|l|}{ Stockholm } \\
\hline $\begin{array}{l}\text { School } \\
\text { of Economics }\end{array}$ & 18 & 5 & 16 & 34 \\
\hline \multicolumn{5}{|l|}{ Linköping } \\
\hline Economics) & 0 & 0 & 0 & 2 \\
\hline \multicolumn{5}{|l|}{ University of } \\
\hline Agriculture & 0 & 0 & 2 & 8 \\
\hline $\begin{array}{l}\text { University of } \\
\text { Forestry }\end{array}$ & 0 & 0 & 3 & 7 \\
\hline Total & $229^{\mathrm{a}}$ & 76 & 43 & $220^{\mathrm{b}}$ \\
\hline
\end{tabular}

Source: The table is compiled from a register made for this study.

Notes: "The figure refers to 229 licentiate theses written by 226 authors. Three students presented two theses. In two of these cases the first thesis was presented at Stockholm, the second at Uppsala. In the third case both were presented at Uppsala. The reason for presenting a second thesis was to get a higher mark. In some cases a second version of the same thesis was presented. These cases are not included here.

The figures refer to the number of people who defend theses. The number of theses is lower: in one case three students had defended a thesis which they had written together and in four cases two students co-authored their theses.

new licentiate degrees. These differences were due mainly to the fact that the new licentiate was not introduced at all universities in the same year, and that the policies regarding its implementation vary between departments.

The great variation in the number of new Ph.D. theses between universities can probably be explained, at any rate partially, by differences between the departments as regards the number of research students and resources, and particularly regarding the number of advisers. For an analysis of this situation we need some basic facts about the number of research students at the universities (table 4.5), which should then be related to the number of Ph.D. theses at the same universities according to table 4.2.

In a first comparison the number of theses is related to the total 


\section{Introduction and background studies}

Table 4.5 Average number of registered Ph.D. students and total number of students registered at least once as Ph.D. students in economics

\begin{tabular}{|c|c|c|c|c|c|c|c|}
\hline Ph.D. students & $U U$ & $L U$ & $G U$ & $\begin{array}{l}\text { University } \\
\quad S U\end{array}$ & $U m U$ & $H H S$ & Total \\
\hline \multicolumn{8}{|l|}{ Average } \\
\hline $\begin{array}{l}\text { Autumn } 71- \\
\text { Spring } 77^{6} \\
\text { Autumn } 77-\end{array}$ & 35 & 45 & 59 & 50 & 7 & 15 & 210 \\
\hline Spring 83 & 43 & 46 & 38 & 67 & 16 & 15 & 222 \\
\hline $\begin{array}{l}\text { Autumn } 83- \\
\text { Autumn } 89\end{array}$ & 39 & 41 & 51 & 53 & 18 & 18 & 216 \\
\hline \multicolumn{8}{|c|}{ Average - full-time students } \\
\hline Autumn 89 & 25 & 25 & 38 & 26 & 8 & 12 & 132 \\
\hline \multicolumn{8}{|c|}{ Average - full-time equivalents ${ }^{\mathrm{c}}$} \\
\hline Autumn '89 & 30 & 31 & 43 & 34 & 11 & 15 & 163 \\
\hline \multicolumn{8}{|c|}{$\begin{array}{l}\text { Total number registered } \\
\text { Autumn '69- }\end{array}$} \\
\hline Autumn '89 & 169 & 195 & 218 & 272 & 94 & 89 & 1,037 \\
\hline \multicolumn{8}{|c|}{$\begin{array}{l}\text { Theses compared to the total number registered } \\
\text { Autumn ' } 69 \text { - }\end{array}$} \\
\hline Autumn 89 & 0.14 & 0.22 & 0.18 & 0.17 & 0.21 & 0.38 & 0.20 \\
\hline
\end{tabular}

Source: Computations for this chapter from the 'Research Student Register' from Statistics Sweden, Orebro and the register of Ph.D. theses made for this study.

Notes: "Those registered as non-active students (activity rate 0 per cent) are not included in the figures.

- The Swedish academic year is divided into two terms.

' The number of research students weighted by their activity rate.

number of postgraduate students ever registered. It is easy to see that the number - 0.38 - is much higher for the Stockholm School of Economics than for the universities. For these last the rate varies from 0.14 for Uppsala to 0.22 for Lund. There are two factors that may explain the higher rate for the Stockholm School of Economics. Probably the more important of these is that postgraduate students there are financed from the start by the School. The second is that students who embark on a postgraduate course in economics at the Stockholm School of Economics have generally decided at an early stage in their undergraduate studies that they will ultimately write a $\mathrm{Ph}$.D. thesis in economics. Business administration is the major area of study at the School, and only students with a strong interest in economics pursue the subject far enough at the undergraduate level to 
qualify for postgraduate studies. In many cases at the universities the decision to begin (serious) studies for a Ph.D. is probably not made until the student has undergone a trial period and been registered as a research student. Quite a few have studied economics for three terms as part of their undergraduate course, thereby qualifying themselves to study for a Ph.D.

Up to 1988,959 people had been registered as Ph.D. students in economics; 170 of them had presented theses and 213 were registered as active students (autumn term 1987). That leaves 576 people to account for. Some of them were probably registered as students with an 'zero activity rate'. Most of them had probably dropped out of the university system, very few of them with new licentiate degrees. The majority had completed a few courses only before leaving the university.

For students who do remain on the course, it is essential to have a thesis adviser - a professor or a docent. ${ }^{10}$ Since the number of chairs in economics has increased considerably over the last decade (cf. Chapter 2), the situation has improved. But the supervision of those who have received $\mathrm{Ph}$.D. degrees is limited to a small number of professors in economics. "Altogether 44 people have been referred to as supervisors in the thesis prefaces of the 203 who have received $\mathrm{Ph}$.D. degrees at the non-specialized universities. Twelve people (eleven professors and one docent) have acted as supervisors for 121 of the 203 candidates.

Conditions were much the same under the old system. Altogether 36 people have acted as examiner for at least one student for the old licentiate degree. Eight professors have been examiners for more than half the students (Johan Åkerman has the highest score, with 25 out of 229, Erik Lundberg the second highest with 17, and Gösta Bagge the third highest with 14).

The number of professors and associate professors (docent), more than 40 now and around 30 at the beginning of the 1970s, is not low in relation to the number of research students and it is high in relation to the number of theses. Thus the small number of theses in economics cannot be explained by there being few chairs in economics.

Another factor behind the result of Ph.D. studies is the intellectual climate in the departments of economics. See e.g Klamer and Colander (1990) for some examples of the importance of this in the United States. As regards Sweden, Uppsala has already been mentioned as an example in earlier decades, as the quotation below illustrates.

I spent the spring term of 1950 in Uppsala. I received a chilly reception. The young researchers kept close watch on one another's 


\section{Introduction and background studies}

doings and remarks and the competition was fierce. Several promising researchers never got further than achieving a licentiate degree, a few then moved to other areas, primarily Stockholm, which is why the number of doctoral theses was low. There was almost no collaboration between Professors Lindahl and Palander, and in that respect the situation resembled the dissension between Gustav Cassel and Knut Wicksell in their time, even if the schism between them was not as profound.'

(Hegeland, 1988: 279)

On the other hand, much work on Ph.D. theses has been done outside the departments of economics. Many have for example written their theses at IUI (c. 20), the Institute for International Economic Studies (c. 10), and at the Swedish Institute for Social Research (c. 10). IUI produced many theses especially in the 1960s and the 1970s, and the two other institutes many in the 1980s. Most of those theses have been presented at Stockholm university and the Stockholm School of Economics.

The financing of the Ph.D. studies is also crucial to the number of completed Ph.D. theses. The universities have funds for doctorate fellowships, but the number of Ph.D. students far exceeds the number of fellowships, which in any case do not cover all the costs. The maximum period for a fellowship is four years: the sums are modest and do not cover such things as expenses and travel costs. However, most of the students get extra support from sources outside the university (table 4.6). As many as 183 students, more than 80 per cent, mention such support in the preface to their theses. Sector-specific government research foundations (labour market, energy, building, foreign aid), bank research foundations and other private research foundations are often mentioned alongside the general research foundations. Unfortunately it has not been possible to estimate the size of the grants paid.

The number of Ph.D. degrees awarded in economics is small in relation to the number of research students and to the number of professors. This does not tell us whether the number of Ph.D. degrees is small in relation to the demand for qualified economists or to the situation in other countries. It is possible to find comparable statistics for the United States. The number of Ph.D. degrees in economics awarded in Sweden during the 1980s was 1.6 per cent of the number awarded in the United States. As the Swedish population is 3.7 per cent of that of the United States, the relative examination rate in the United States is more than twice as high as that in Sweden. This rate is 
Recruiting a new generation 79

Table 4.6 Financial support for $\mathrm{Ph}$. D. theses as indicated by prefaces to theses

\begin{tabular}{|c|c|c|c|c|c|c|c|c|}
\hline \multirow[b]{2}{*}{ Financing } & \multirow[b]{2}{*}{$\mathrm{UU}$} & \multirow[b]{2}{*}{ LU } & \multirow[b]{2}{*}{ GU } & \multicolumn{2}{|c|}{ University } & \multirow[b]{2}{*}{ HHS } & \multirow[b]{2}{*}{ Other } & \multirow[b]{2}{*}{ Total } \\
\hline & & & & SU & $\mathrm{UmU}$ & & & \\
\hline $\mathbf{R J}$ & 4 & 7 & 5 & 9 & 0 & 9 & 0 & 34 \\
\hline HSFR & 4 & 11 & 8 & 9 & 1 & 3 & 1 & 37 \\
\hline SJFR & 0 & 0 & 0 & 0 & 0 & 0 & 5 & 5 \\
\hline FRN & 1 & 0 & 0 & 0 & 1 & 0 & 1 & 3 \\
\hline KVA & 0 & 0 & 2 & 3 & 0 & 0 & 0 & 5 \\
\hline EFN & 1 & 0 & 3 & 2 & 0 & 2 & 0 & 8 \\
\hline SAREC & 0 & 4 & 5 & 5 & 0 & 0 & 1 & 15 \\
\hline A-dep./AMS & 0 & 4 & 1 & 0 & 5 & 2 & 0 & 12 \\
\hline BFR & 0 & 2 & 3 & 2 & 3 & 0 & 0 & 10 \\
\hline \multicolumn{9}{|l|}{ Other state } \\
\hline sources & 3 & 4 & 7 & 4 & 1 & 4 & 2 & 25 \\
\hline Bank foun- & & & & & & & & \\
\hline $\begin{array}{l}\text { dations } \\
\text { Finanspolitiska }\end{array}$ & 9 & 3 & 11 & 8 & 2 & 12 & 0 & 45 \\
\hline institute & 5 & 2 & 0 & 1 & 0 & 3 & 0 & 11 \\
\hline $\begin{array}{l}\text { Other private } \\
\text { foundations }\end{array}$ & 2 & 2 & 4 & 7 & 2 & 10 & 2 & 29 \\
\hline Research & 2 & 2 & 4 & $f$ & 2 & 10 & 2 & 29 \\
\hline institutes & 6 & 6 & 0 & 8 & 2 & 3 & 0 & 25 \\
\hline $\begin{array}{l}\text { Nordic council } \\
\text { Other non- }\end{array}$ & 0 & 0 & 1 & 0 & 0 & 0 & 0 & 1 \\
\hline Swedish & 3 & 3 & 2 & 1 & 0 & 1 & 1 & 11 \\
\hline Other & 2 & 0 & 0 & 0 & 1 & 0 & 0 & 3 \\
\hline $\begin{array}{l}\text { No outside } \\
\text { financial }\end{array}$ & & & & & & & & \\
\hline support & 1 & 11 & 8 & 5 & 3 & 3 & 3 & 37 \\
\hline
\end{tabular}

Source: This table is compiled from a register made for this study.

Note: " RJ = The Bank of Sweden Tercentenary Foundation, HSFR = The

Swedish Council for Research in the Humanities and Social Sciences, SJFR $=$ The Swedish Council for Forestry and Agriculture Research, FRN = The Coordinating Board of the Swedish Research Councils, KVA = The Swedish Royal Academy of Sciences, EFN = The Energy Research Commission, SAREC $=$ The Swedish Agency for Research Cooperation with Developing Countries, A-dep./AMS = The Ministry of Labour/The Labour Market Board, BFR $=$ The Swedish Council for Building Research.

probably not specific to $\mathrm{Ph} . \mathrm{D}$. degrees in economics, but is just one result of the fact that a greater proportion of young people continue into higher education in the United States than in Sweden (see Fägerlind 1991). 
80 Introduction and background studies

Table 4.7 Average age of those completing theses in economics

\begin{tabular}{|c|c|c|c|c|}
\hline University & $\begin{array}{l}\text { Old } \\
\text { Lic. }\end{array}$ & $\begin{array}{c}\text { Old } \\
\text { Ph.D. }\end{array}$ & $\begin{array}{c}\text { New } \\
\text { Lic. }\end{array}$ & $\begin{array}{c}\text { New } \\
\text { Ph.D. }\end{array}$ \\
\hline Uppsala & 30.5 & 34.5 & 40.6 & 35.5 \\
\hline Lund & 30.8 & 35.6 & ()$^{a}$ & 34.5 \\
\hline Gothenburg & 30.7 & 39.1 & () & 36.3 \\
\hline Stockholm & 31.2 & 33.2 & 38.2 & 37.4 \\
\hline Umeå & () & - b & () & 35.8 \\
\hline HHS & 31.6 & 34.0 & 31.4 & 33.9 \\
\hline Total $^{c}$ & 30.9 & 34.6 & 35.3 & 35.6 \\
\hline
\end{tabular}

Source: This table is compiled from a register made for this study.

Notes: "few observations (less than five)

no observations

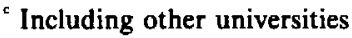

\section{AN Ageing POPUlation OF Ph.D. STUDENTS}

One of the main goals of the new system was to reduce the period of study, which would generally mean that students presenting Ph.D. theses were younger than before. According to the government committee which proposed the new system, the standard period of study would be four years and the standard age 28 . Those who occupied positions as assistants in the department were expected to be one year older, i.e. 29. Table 4.7 shows that in economics the age goal has not been attained. The average age has been 35.6 , the standard deviation 5.1 and the median 34 . Only 16 of the 220 were 29 years old or less, while considerably more -47 - were 40 years old or more (age is calculated as from the year of the thesis minus the year of birth).

We can compare this with the median age of 32.0 for Ph.D. recipients in economics in the United States, i.e. two years lower (Thurgood and Weinman 1990: 71). ${ }^{12}$

There are some differences between the universities. The table shows that the students completing their Ph.D. degrees at Lund University and the Stockholm School of Economics are younger than the average while at Stockholm University they are older. This last might be due partly to people combining work in the governmental sector with the writing of a Ph.D. thesis. It is also interesting to note that table 4.7 shows the same average age for those receiving the new licentiate and those receiving the new Ph.D. This may be a transitional phenomenon, with 'veterans' being granted licentiates of the new kind. An 
alternative hypothesis is that the study time is 'fixed', but that quality determines whether a thesis qualifies for a Ph.D. or a licentiate. Future developments will show whether either of these hypotheses is correct.

Not only has the original goal to lower the age of students completing the Ph.D. not been achieved, but the opposite applies: those completing the new Ph.D. are even older than those who completed the Ph.D. or the licentiate under the old system! However, the picture looks a little different if we restrict the comparison to those awarded the Ph.D. or licentiate degrees in the mid-1960s. The average age was higher for those getting the old $\mathrm{Ph} . \mathrm{D}$. at that time than for those awarded the new one, but the difference is only slightly more than one year.

At the turn of the century a person receiving an old licentiate degree was 28.9 years old on an average; in the mid-1960s when discussions about a reform began, the corresponding figure according to the regression estimates in table 4.8 was 31.4. The corresponding figures for the old Ph.D. were 31.8 and 35.7. According to the regression estimates the average age of those obtaining the new Ph.D. degree in 1989 was 37.6 years, i.e. higher than the average age for those obtaining the old Ph.D. just before the reform. More worrying is that the age of those receiving the new Ph.D. has risen by three months every year according to the regression estimates. The question then is whether this trend will continue. The answer depends on the age of those embarking on their studies today, and on the time they take. As can be seen from table 4.9 the median age of new students in the $1980 \mathrm{~s}$ varied between 26.5 and 28.5, and between 32 and 33.5 for all active students. There are no signs of a drop in age for those embarking on Ph.D. courses or for those working on a Ph.D. thesis. On the other hand there is no tendency in the opposite direction, which may imply a stabilization at the present age level.

The advanced age of those presenting their theses cannot, however, be explained solely in terms of age at the start of the course programme. Long study periods are equally important. If we compare the average number of theses $(c .12)$ with the average number of active students (c. 220), we can estimate that eighteen active years are necessary for each thesis. However, many students work part-time. If we take the average number of full-time years (165) instead, the corresponding figure will be fourteen. This is still an overestimation of the average period of study for a completed Ph.D., since many students drop out. ${ }^{13}$

According to statistics from the research student register at Statistics Sweden, the median time from the first degree to the Ph.D. 


\section{Introduction and background studies}

Table 4.8 Candidates' age at examination over time (Age $=a+b *$ time)

\begin{tabular}{lcccccc}
\hline Degree & $a$ & $b$ & $R^{2}$ adj & $n$ & $\begin{array}{c}\text { Average } \\
\text { age }\end{array}$ & $\begin{array}{c}\text { Time=0 } \\
\text { for }\end{array}$ \\
\hline Old Lic. & $\begin{array}{l}28.873 \\
(0.859)^{\mathrm{b}}\end{array}$ & $\begin{array}{c}0.040 \\
(0.016)\end{array}$ & 0.022 & 226 & 30.8 & 1900 \\
Old Ph.D. & $\begin{array}{l}31.492 \\
(1.641)\end{array}$ & $\begin{array}{c}0.064 \\
(0.032)\end{array}$ & 0.040 & 76 & 34.6 & 1895 \\
New Ph.D. & $\begin{array}{l}32.608 \\
(0.265\end{array}$ & 0.077 & 220 & 35.5 & 1970 \\
\hline
\end{tabular}

Source: This table is based on a register made for this study.

Notes: - Three people presented two theses, only the first is included in the estimation.

'Standard errors in parentheses.

Table 4.9 Median age of research students in economics

\begin{tabular}{lcc}
\hline Academic year & New students & $\begin{array}{c}\text { All those } \\
\text { registered as active } \\
\text { research studies }\end{array}$ \\
\hline $1972-3$ & 25.5 & 29.0 \\
$1973-4$ & 26.5 & 29.0 \\
$1974-5$ & 28.0 & 30.0 \\
$1975-6$ & 26.5 & 30.5 \\
$1976-7$ & 25.5 & 31.0 \\
$1977-8$ & 27.5 & 31.5 \\
$1978-9$ & 30.5 & 32.0 \\
$1979-80$ & 27.0 & 32.0 \\
$1980-1$ & 28.5 & 32.0 \\
$1981-2$ & 27.5 & 32.0 \\
$1982-3$ & 28.5 & 32.5 \\
$1983-4$ & 27.5 & 32.5 \\
$1984-5$ & 28.0 & 32.5 \\
$1985-6$ & 26.5 & 32.5 \\
$1986-7$ & 28.5 & 33.5 \\
$1987-8$ & 26.5 & 33.5 \\
$1988-9$ & 27.5 & 33.5 \\
$1989-90$ & 28.5 & 32.5 \\
\hline
\end{tabular}

Source: 'Research Student Register' from Statistics Sweden, Orebro.

was 12.0 years in 1988-9 and 10.0 in $1989-90 .^{14}$ The median number of years from acceptance as a research student to completion of the Ph.D. was 9.5 and 10.0 respectively, and the median number of years 
Recruiting a new generation 83

Table 4.10 Median study time for a new Ph.D. degree in economics 1974-90 in number of terms (two terms per calendar year)

\begin{tabular}{lccc}
\hline $\begin{array}{l}\text { Academic } \\
\text { year }\end{array}$ & $\begin{array}{c}\text { Gross study time } \\
\text { (since acceptance } \\
\text { on Ph.D. } \\
\text { programme) }\end{array}$ & $\begin{array}{c}\text { Net study time } \\
\text { (since acceptance } \\
\text { on Ph.D. } \\
\text { programme) }\end{array}$ & $\begin{array}{c}\text { Time from first } \\
\text { academic degree }\end{array}$ \\
\hline $1974-5$ & 13.0 & 10.5 & \\
$1975-6$ & 13.0 & 8.0 & 17.0 \\
$1976-7$ & 15.5 & 10.4 & 17.0 \\
$1977-8$ & 17.0 & 14.0 & 19.0 \\
$1978-9$ & 16.0 & 13.8 & 16.0 \\
$1979-80$ & 19.5 & 14.2 & 20.0 \\
$1980-1$ & 19.0 & 13.0 & 23.5 \\
$1981-2$ & 16.0 & 10.2 & 24.0 \\
$1982-3$ & 17.0 & 11.9 & 21.0 \\
$1983-4$ & 17.0 & 14.4 & 19.0 \\
$1984-5$ & 17.5 & 11.0 & 22.0 \\
$1985-6$ & 14.0 & 12.0 & 19.0 \\
$1986-7$ & 24.0 & 17.7 & 27.0 \\
$1987-8$ & 16.0 & 13.0 & 21.0 \\
$1988-9$ & 19.0 & 14.0 & 24.0 \\
$1989-90$ & 20.0 & 14.0 & 20.0 \\
\hline
\end{tabular}

Source: 'Research Student Register' from Statistics Sweden, Orebro.

of full-time studies up to the completion of the Ph.D. was 7.0 in both academic years (table 4.10). ${ }^{14}$ As can be seen from table 4.10 there is a tendency towards longer periods of study. The intended decrease in age at the time of completing the thesis has not been obtained, and there is a clear tendency towards an increase.

\section{FEW WOMEN WITH Ph.D. DEGREES}

Most of the researchers and teachers at the universities are male. This has worried several government committees, the latest of which is a committee on the appointment of professors (SOU 1989: 30). Economics is one of the most segregated disciplines in the social sciences. The great majority of research students in economics are men. Only 9 per cent of those presenting a new Ph.D. thesis have been women. ${ }^{16}$ The share is higher for the new licentiate degree, namely 21 per cent. This may be interpreted as an indication of an increase in the percentage of female research students in economics. However, another interpretation is that women are more inclined to stop after the lower degree, while men go on to a Ph.D. It is too early to say 


\section{Introduction and background studies}

Table 4.11 Theses in economics by type of degree and sex

\begin{tabular}{lrrrrrrrr}
\hline & \multicolumn{3}{c}{ Old Lic. } & \multicolumn{2}{c}{ Old Ph.D. } & \multicolumn{2}{c}{ New Lic. } & \multicolumn{2}{c}{ New Ph.D. } \\
& \multicolumn{1}{c}{ No. } & \multicolumn{1}{c}{$\%$} & \multicolumn{1}{c}{ No. } & \multicolumn{1}{c}{$\%$} & \multicolumn{1}{c}{ No. } & $\%$ & \multicolumn{1}{c}{ No. } & $\%$ \\
\hline Men & 219 & 96.9 & 74 & 97.4 & 34 & 79.1 & 201 & 91.4 \\
Women & 7 & 3.1 & 2 & 2.6 & 9 & 20.9 & 19 & 8.6 \\
Total & 226 & 100 & 76 & 100 & 43 & 100 & 220 & 100 \\
\hline
\end{tabular}

Source: The table is compiled from a register made for this study.

Note: "Three people presented two theses; only one per person is included in this table.

which of the two explanations carries most weight. The new licentiate degree has not been with us for long, and the pattern may change in the years to come. Although the percentage of women presenting new $\mathrm{Ph}$.D. theses in economics is low, it was even lower before. Only two women, Margit Cassel (1924) and Karin Kock (1929), obtained Ph.D. degrees in economics under the old system.

The proportion of women among research students has been growing slowly ever since the new system was introduced 20 years ago. In the spring term of 1972, 12 per cent of those studying for a Ph.D. were women. Of those newly registered between the autumn term of 1972 and the end of the 1980s, 15 per cent were women (table 4.1), and the proportion was higher in the 1980s than in the 1970s. Of all research students (with an activity rate above zero) in the autumn term of 1989, 18 per cent were women. This means that in the first half of the 1990s there will be an increase in the number of female Ph.D. degrees. To achieve a substantial increase, however, the inflow of women students into Ph.D. studies will first have to increase more.

\section{Ph.D. DEGREES IN ECONOMICS AWARDED TO SWEDISH CITIZENS IN THE UNITED STATES}

As was pointed out in the introduction to this chapter, most Swedish economists are trained in Sweden and receive their Ph.D. degrees in that country. A few, however, receive their Ph.D. degrees elsewhere, most of them in the United States. Table 4.12 shows how many Swedish citizens obtained a Ph.D. in economics in the United States during the last three decades.

Altogether 21 Swedish citizens have obtained American Ph.D. degrees in economics in the period covered. Between 1970 - when the first Ph.D. degrees in economics according to the new system were 
Table 4.12 Gender and age of Swedish citizens receiving Ph.D. degree in economics from the United States

\begin{tabular}{crrccc}
\hline $\begin{array}{c}\text { Year of } \\
\text { Ph. D. }\end{array}$ & Total & Male & Female & Mean Age & Median Age \\
\hline 1960s & 5 & 5 & 0 & 32.8 & 32 \\
$1970 \mathrm{~s}$ & 11 & 11 & 0 & 30.4 & 30 \\
$1980 \mathrm{~s}$ & 5 & 2 & 3 & 31.4 & 30 \\
Total & 21 & 18 & 3 & 31.2 & 31 \\
\hline
\end{tabular}

Source: Survey of Earned Doctorates. The Survey of Earned Doctorates is sponsored by five federal agencies (National Science Foundation (NSF), National Institutes of Health (NIH), US Department of Education (USDE), National Endowment for the Humanities (NEH), and the US Department of Agriculture (USDA)), and is conducted by the National Research Council (NRC). This table is based on computations made for the present study by the National Research Council.

granted in Sweden - and 1989, sixteen Ph.D. degrees were granted to Swedish citizens in the United States compared with 203 at the Swedish universities (excluding those in specialized programmes). As thirty to thirty-five of the Ph.D. recipients in economics in Sweden were foreign citizens, this means that about 10 per cent of all Swedish citizens who have obtained a Ph.D. in economics have done so in the United States.

Table 4.12 also shows, perhaps somewhat surprisingly, that the number of Swedish Ph.D. degrees from the United States was higher in the 1970s than in the 1980s, namely 11 as against 5 . One explanation may be that the relative quality of the Ph.D. programmes in Sweden improved over this period. The percentage of women among the Swedish citizens awarded a Ph.D. in the United States is low, as it is in Sweden. One difference, however, is that the Swedish citizens who obtained a Ph.D. in economics in the United States are younger than their counterparts in Sweden. In the 1970s as well as in the 1980s the median age for Swedish citizens receiving a Ph.D. in the United States was 30.

We do not know how many of the Swedish citizens who have been awarded a Ph.D. in economics in the United States have returned to Sweden, nor how many have received a Ph.D. in economics in some other country and how many of them may have returned to Sweden. It seems probable that there are more non-Swedish citizens who have acquired a Ph.D. in economics in Sweden than Swedish citizens who have obtained $\mathrm{Ph} . \mathrm{D}$. degrees in economics abroad. It is also clear that there are more economists with a Swedish Ph.D. who work abroad 


\section{Introduction and background studies}

(see table 4.19), than there are economists with a foreign Ph.D. (Swedish or non-Swedish citizens) working in Sweden.

\section{THE FORM AND CONTENT OF THE THESES}

One of the reasons for the long periods of study may be sought in the changes affecting the form and content of the theses. It is important to note that two of the changes mentioned above in connection with the evolution of the system may have implied an increase in the minimum level of acceptable quality. The reinstatement of the examination committee and the change in its composition (excluding the thesis adviser), may have meant that people extended their period of study: risk-averse students (and advisers) try to avoid falling below or too close to the minimum standard, which may mean spending time completing the thesis. Up to now all defended $\mathrm{Ph} . \mathrm{D}$. theses in economics except one have been approved (and all by a unanimous vote).

The committee that drew up the proposal for the new Ph.D. wanted shorter theses. Limiting the printing grant to 160 pages was one attempt at achieving this. And theses are shorter now. The average for the new Ph.D. is 231 page, as compared to 320 for an old one. But the 231 -average is 44 per cent higher than the intended maximum. Only 20 per cent of all theses have had 160 pages or fewer. The length of the theses may thus provide one explanation for the long period of study required."

Theses written in Swedish are on an average longer, 248 pages, than those written in English, 220 pages. For the old Ph.D., the average length of theses written in Swedish was 344 pages; English, 279 pages; and German, 214 pages.

The committee also wanted to encourage theses consisting of published articles together with a concluding summary. Up to 1991 only four theses of this kind have been presented in economics. More common are theses consisting at least in part of revised versions of already published articles or a mixture of published and unpublished articles.

As was mentioned on pages $68-71$, it is not necessary to have a new $\mathrm{Ph}$.D. printed. The rules specify a minimum number of copies but not the processing technique; this is a difference compared to the old system. Although one intention underlying this change was to shorten the period of study, in practice it has had little effect. Most theses are now printed as books as well, and this may be yet another reason why completion times have become longer than intended. But the import- 
ance of this last factor should not be overestimated, as changes in printing techniques have greatly shortened the printing time. Many students present camera-ready manuscripts for printing, thus considerably reducing production times.

Another reason for lengthy periods of study may be the increasing tendency to write in languages other than Swedish. A thesis at a Swedish university may be written in English, French or German as well as in any of the Scandinavian languages (Swedish, Danish, Norwegian). During this century theses in economics in Sweden have been written in three languages only - Swedish, English and German (table 4.13). Less than a third of the old Ph.D. theses were written in a language other than Swedish. Most of those were in English, but a few were in German. Most of them were published at the beginning of the century. Among the best-known theses in German are those by Knut Wicksell (Zur Lehre von der Steuerincidenz, Uppsala 1895), Erik Lindahl (Die Gerechtigkeit der Besteurung, Lund 1919), Gustaf Åkerman (Realkapital und Kapitalzins, Lund 1923) and Tord Palander (Beiträge zur Standorts-Theorie, Stockholm, 1935). Those published in English date mainly from a later period. Of early theses in English, those by Karin Kock ( $A$ Study of Interest Rates, Stockholm 1927) and Erik Lundberg (Studies in the Theory of Economic Expansion, Stockholm 1937) may be mentioned. Bertil Ohlin's thesis (Handelns teori, Stockholm 1924) was written in Swedish, but was developed and extended in a later English version (Interregional and International Trade, Harvard University Press 1933). Among the more interesting theses that were inaccessible to those unable to read Swedish may be mentioned those by Gösta Bagge (Arbetslönens reglering genom sammanslutningar, Stockholm 1917) and Gunnar Myrdal (Prisbildningsproblemet och föränderligheten, Stockholm 1927). ${ }^{18}$

The government committee preparing the proposal for the new system was strongly in favour of publication for an international public. In the first few years of the new system a little over half the theses were written in Swedish. Now English is the most common language, and in recent years few theses have been written in Swedish (table 4.14). ${ }^{19}$ Most of those presenting theses in Swedish in the last five years had been working on them for a long time, starting when it was more common to write in Swedish. Most women economists have written their theses in Swedish. Of new licentiate theses, the majority are in English, but the proportion is slightly lower than for the new Ph.D.

Writing in English enables the author to reach economists outside Scandinavia (nowadays only a few theses are read by any except 


\section{Introduction and background studies}

Table 4.13 Theses in economics by type of degree and language

\begin{tabular}{lrrrrrrrr}
\hline & \multicolumn{2}{c}{ Old Lic. } & \multicolumn{3}{c}{ Old Ph.D. } & \multicolumn{2}{c}{ New Lic. } & \multicolumn{2}{c}{ New } & Ph.. \\
& No. & $\%$ & No. & $\%$ & No. & $\%$ & No. & $\%$ \\
\hline Swedish & 202 & 91.0 & 54 & 71.1 & 19 & 44.2 & 81 & 36.8 \\
English & 18 & 8.1 & 16 & 21.1 & 24 & 55.8 & 139 & 63.2 \\
German & 2 & 0.9 & 6 & 7.9 & 0 & 0.0 & 0 & 0.0 \\
Total & $222^{\mathrm{a}}$ & 100 & 76 & 100 & 43 & 100 & 220 & 100 \\
\hline
\end{tabular}

Source: The table is compiled from a register made for this study.

Note: "The total number is 229 , but as it has not been possible to obtain information on the subjects and consequently the language of 7 theses, these have not been included in the table.

Table 4.14 New Ph.D. theses $1970-89$ by language

\begin{tabular}{lcccc}
\hline & Swedish & \multicolumn{2}{c}{ English } \\
& No. & $\%$ & No. & $\%$ \\
\hline $1970-4$ & 13 & 52 & 12 & 48 \\
$1975-9$ & 35 & 56 & 28 & 44 \\
$1980-4$ & 18 & 35 & 34 & 65 \\
$1985-9$ & 15 & 19 & 65 & 81 \\
Total & 81 & 37 & 139 & 63 \\
\hline
\end{tabular}

Source: The table was compiled from a register made for this study.

specialists), but it can also be regarded as an opportunity to practise writing in English. Many theses are never widely distributed but they constitute a basis for publishing articles in scientific journals. Writing in a foreign language may have contributed to prolonging the period of study, but it can also be seen as preparation for further research work.

To shorten the time it takes to complete a thesis, some changes in its form have been tried. Two examples are the encouragement of shorter theses, and of theses consisting of three to five articles not yet published or accepted for publication.

\section{THE FACULTY OPPONENT ${ }^{20}$}

The faculty opponent at the public defence of a doctoral thesis is a very important person in the examination of a thesis. The opponent 
generally starts by providing an overview of the thesis, lasting for about a quarter of an hour, following this by about two hours of critical discussion of the thesis. The author of the thesis (the 'respondent') replies to the opponent's critical comments. After the faculty opponent's examination other people, including members of the examination committee, may ask questions or make comments (although in most cases few do so). This procedure is in practice about the same for the new licentiate. (The procedure differs between universities, however.)

The present procedure for examining a Ph.D. thesis closely resembles that of the old system. The main difference is that there is now only one opponent, whereas there used to be two. The main function of the second opponent was to make a more detailed examination of the way the thesis was presented.

Under the old $\mathrm{Ph} . \mathrm{D}$. system the opponents were very often chosen from the candidate's own university. As we have seen, a docent was obliged to accept the task of acting as opponent at his own university (table 4.15). In many cases someone from the Stockholm School of Economics would act as opponent at Stockholm University. Few opponents were chosen from outside Scandinavia, partly because most theses were written in Swedish. International travel was also more time-consuming in those days, and therefore more expensive. Moreover, it was not regarded as a problem to choose an opponent from the candidate's own university. There were no departments then, so people did not all work at the same place. They only met at the licentiate seminars. For this and other reasons there was generally a much greater social distance between the respondent and the opponent than there would be today, were the opponent to come from the same university.

The committee preparing the new system discussed the possible introduction of a rule making it compulsory to choose an opponent from outside the candidate's department. This was not made the generaı rule, however, because some disciplines were represented only at one university. Table 4.16 shows that the opponents have been chosen from the candidate's university in a few cases only (most of them at Stockholm University and the Stockholm School of Economics, which is a bit surprising in view of the fact that there are three universities close to each other in the Stockholm-Uppsala region). Most cases of using 'internal examiners' occurred in the early years of the new system.

More than half the opponents have been chosen from outside Sweden. About half this number have come from the Nordic 


\section{Introduction and background studies}

Table 4.15 Faculty opponent at oral defence of theses in economics according to type of degree and origin

\begin{tabular}{lccc}
\hline $\begin{array}{l}\text { Opponent } \\
\text { from }\end{array}$ & $\begin{array}{c}\text { Old } \\
\text { Ph. D. }\end{array}$ & $\begin{array}{c}\text { New } \\
\text { Lic. }\end{array}$ & $\begin{array}{c}\text { New } \\
\text { Ph. D. }\end{array}$ \\
\hline Same university & 37 & 5 & 13 \\
Other university: & 2 & 5 & 6 \\
of which UU & 2 & 3 & 15 \\
$\quad$ LU & 3 & 3 & 7 \\
$\quad$ GU & 4 & 4 & 15 \\
$\quad$ UmU $\quad$ HHS & 0 & 3 & 15 \\
Other university apart & 7 & 4 & 8 \\
from the above & & & \\
Sweden, non-university & 0 & 3 & 3 \\
Denmark & 6 & 5 & 19 \\
Norway & 3 & 1 & 20 \\
Finland & 9 & 2 & 37 \\
United Kingdom & 1 & 0 & 3 \\
United States & 0 & 1 & 15 \\
Other countries & 2 & 3 & 28 \\
& 0 & 1 & 16 \\
Total & & 43 & 220 \\
\hline
\end{tabular}

Source: This table is compiled from a register for this study.

countries, and half from other countries (table 4.15). Nineteen opponents were Swedes not affiliated to any Swedish university. In most cases they were working at research institutes outside the universities. The table also shows that the overwhelming majority of the opponents from abroad were from four countries: Denmark, Norway, the United Kingdom and the United States. Few opponents come from Finland, which may be explained by the language barrier. Further, only a few opponents for new licentiate theses have come from the same university as the respondent. On the other hand not many of them have been recruited from outside Sweden.

Generally speaking the current system for selecting opponents seems to be satisfactory in most respects. Today the opponent is almost always chosen from outside the candidate's university, which means that the thesis is examined by someone who has not been involved in advising the student. Most opponents come from Sweden or one of the other Nordic countries (Denmark, Finland, Norway) which means that the opponents are generally well acquainted with the 
Recruiting a new generation 91

Table 4.16 Faculty opponent for $\mathrm{Ph} . \mathrm{D}$. oral defence in economics according to the new system

\begin{tabular}{|c|c|c|c|c|c|c|c|c|c|}
\hline $\begin{array}{l}\text { Opponent } \\
\text { from }\end{array}$ & $U U$ & $L U$ & $G U$ & $\begin{array}{c}\text { heses } \\
\text { SU }\end{array}$ & $\stackrel{a t}{U m U}$ & $H H S$ & Other & Total & $\%$ \\
\hline Uppsala & 1 & 2 & 1 & 1 & 2 & 1 & 0 & 7 & 3.2 \\
\hline L.und & 1 & 1 & 4 & 3 & 3 & 2 & 2 & 16 & 7.3 \\
\hline Gothenburg & 2 & 1 & 1 & 2 & 0 & 2 & 0 & 8 & 3.6 \\
\hline Stockholm & 3 & 4 & 2 & 6 & 2 & 4 & 0 & 21 & 9.5 \\
\hline Umeå & 1 & 4 & 0 & 4 & 0 & 5 & 1 & 15 & 6.8 \\
\hline HHS & 1 & 2 & 0 & 4 & 1 & 3 & 0 & 11 & 5.0 \\
\hline \multicolumn{10}{|l|}{ Other } \\
\hline Swedish & & & & & & & & & \\
\hline university & 0 & 0 & 1 & 0 & 0 & 1 & 2 & 4 & 1.9 \\
\hline \multicolumn{10}{|l|}{ Other } \\
\hline Sweden & 5 & 5 & 2 & 4 & 1 & 0 & 2 & 19 & 8.6 \\
\hline Denmark & 3 & 5 & 0 & 6 & 1 & 1 & 4 & 20 & 9.1 \\
\hline Norway & 1 & 8 & 14 & 5 & 1 & 6 & 2 & 37 & 16.8 \\
\hline Finland & 0 & 0 & 1 & 0 & 1 & 1 & 0 & 3 & 1.4 \\
\hline \multicolumn{10}{|l|}{ United } \\
\hline Kingdom & 2 & 4 & 5 & 1 & 2 & 1 & 0 & 15 & 6.8 \\
\hline \multicolumn{10}{|l|}{ United } \\
\hline States & 2 & 4 & 8 & 7 & 2 & 2 & 3 & 28 & 12.7 \\
\hline Other & 2 & 2 & 1 & 3 & 2 & 5 & 1 & 16 & 7.3 \\
\hline Total & 24 & 42 & 40 & 45 & 18 & 34 & 17 & 220 & 100 \\
\hline
\end{tabular}

Source: The table is compiled from a register made for this study.

examination system and the role of the opponent. When opponents have been chosen from other countries, the results have ranged from excellent examinations to short lectures on some subject related to that of the thesis.

\section{THE TOPICS OF THE THESES}

These theses constitute an important part of the research in economics in Sweden; they also influence the subjects chosen for further research, since most researchers continue to work in the same area as that of the thesis. The thesis also prepares people for work outside the universities, and the subject chosen for the thesis may thus influence the decisions about leaving the university, as well as the area of the labour market which the new doctors choose to enter.

The theses have been classified by subject according to the system 


\section{Introduction and background studies}

adopted by the Journal of Economic Literature. Each thesis is classified under one heading only. In many respects this is rather an unsatisfactory way of classifying them, since many theses deal with several issues and could be classified in different ways. How for example should a thesis which applies input-output analysis to the agricultural sector of a developing country be classified? According to method (area 2), according to sector (area 7), or according to economic system (area 1)? The distribution of theses according to subject presented in table 4.17 should therefore be interpreted with great caution.

If all the universities are taken together, then the theses can be seen to cover most areas. This does not mean that an even distribution is the norm (the areas are not of 'equal size'). The exceptions to the even pattern are 'administration, business finance, marketing and accounting' (area 5) and 'quantitative economic methods and data' (area 2), which have very few theses. The explanation is probably that most theses in Sweden in area 5 are theses in business administration, and that most in area 2 are theses in statistics, and neither are therefore included in this study. The small number of theses in 'quantitative economic methods and data' (area 2) does not mean that only a few economics theses use such methods. On the contrary, most of the theses are empirically oriented and make use of econometric methods. Few of the theses, however, have the development of econometric methods, for example, as their main theme.

A few differences between the universities can be observed. The most obvious is that the universities of agriculture and forestry specialize in 'agriculture; natural resources' (area 7). Gothenburg University has many theses in 'industrial organization' (area 6), Stockholm University in 'international economics' (area 4), Lund University in 'welfare programmes; consumer economics; urban and regional economics' (area 9) and Umeå University in 'manpower; labour; population' (area 8).

If we extend the analysis to both the old and the new systems (table 4.18), we find some areas of growth and others of absolute or relative decline. The areas of growth are 'international economics' (area 4), 'development studies' (part of area 1), and 'agriculture and natural resources' (area 7). If we look at Ph.D. theses only, 'welfare programmes, consumer economics and urban and regional economics' (area 9) is also an area of growth.

An area of decline in the number of theses is 'general economics; theory; history; systems' (area 0). The old Ph.D. thesis was supposed to contribute to economic theory and many theses were in the area of 
Recruiting a new generation

Table 4.17 Theses (new Ph.D.) 1970-89 by subject and university

\begin{tabular}{|c|c|c|c|c|c|c|c|c|}
\hline \multirow[t]{2}{*}{ Area $^{a}$} & \multicolumn{7}{|c|}{ University } & \multirow[b]{2}{*}{ Total } \\
\hline & $U U$ & $L U$ & $\boldsymbol{G} U$ & $S U$ & $U m U$ & $H H S$ & Others & \\
\hline $\begin{array}{l}\text { General economics; } \\
\text { Theory; History; } \\
\text { Systems (0) }\end{array}$ & 0 & 5 & 3 & 10 & 1 & 8 & 0 & 27 \\
\hline $\begin{array}{l}\text { Economic growth } \\
\text { Development; Plan- } \\
\text { ning; Fluctuations (1) }\end{array}$ & 5 & 7 & 4 & 8 & 1 & 4 & 0 & 29 \\
\hline $\begin{array}{l}\text { Quantitative economic } \\
\text { methods and data ( } 2 \text { ) }\end{array}$ & 0 & 1 & 2 & 2 & 1 & 2 & 1 & 9 \\
\hline $\begin{array}{l}\text { Domestic monetary and } \\
\text { fiscal theory and insti- } \\
\text { tutions ( } 3 \text { ) }\end{array}$ & 3 & 3 & 1 & 4 & 1 & 2 & 0 & 14 \\
\hline $\begin{array}{l}\text { International economics } \\
\text { (4) }\end{array}$ & 1 & 3 & 5 & 9 & 2 & 5 & 0 & 25 \\
\hline $\begin{array}{l}\text { Administration; Busi- } \\
\text { ness finance; Market- } \\
\text { ing; Accounting (5) }\end{array}$ & 2 & 0 & 0 & 1 & 0 & 0 & 0 & 3 \\
\hline $\begin{array}{l}\text { Industrial organization; } \\
\text { Technological change; } \\
\text { Industry studies (6) }\end{array}$ & 5 & 3 & 9 & 6 & 2 & 5 & 0 & 30 \\
\hline $\begin{array}{l}\text { Agriculture; Natural } \\
\text { resources (7) }\end{array}$ & 3 & 6 & 4 & 2 & 0 & 5 & 14 & 34 \\
\hline $\begin{array}{l}\text { Manpower; Labour; Popu- } \\
\text { lation (8) }\end{array}$ & 4 & 5 & 5 & 3 & 7 & 3 & 0 & 27 \\
\hline $\begin{array}{l}\text { Welfare programmes; Con- } \\
\text { sumer economics; Urban } \\
\text { and regional economics } \\
\text { (9) }\end{array}$ & 1 & 9 & 7 & 0 & 3 & 0 & 2 & 22 \\
\hline Total & 24 & 42 & 40 & 45 & 18 & 34 & 17 & 220 \\
\hline
\end{tabular}

Source: The table is compiled from a register made for this study.

Note: Area numbers according to the system of the Journal of Economic Literature in parentheses.

central micro- or macroeconomic theory. An area of relative decline is 'domestic monetary and fiscal theory and institutions' (together with 'business fluctuations' the main research area of the Stockholm School).

Women students have been more inclined than their male counterparts to write theses in applied economics, especially labour economics. As we have already noted, most women have published their theses in Swedish.

Foreign students are overrepresented in the area of 'development 


\section{Introduction and background studies}

Table 4.18 Theses in economics $1895-1989$ by type of degree and subject

\begin{tabular}{|c|c|c|c|c|c|c|c|c|}
\hline \multirow{2}{*}{$\begin{array}{l}\text { Subject } \\
\text { General economics; } \\
\text { Theory; History; }\end{array}$} & \multicolumn{2}{|c|}{$\begin{array}{l}\text { Old Lic. } \\
\text { No. } \%\end{array}$} & \multicolumn{2}{|c|}{$\begin{array}{l}\text { Old Ph.D. } \\
\text { No. } \%\end{array}$} & \multicolumn{2}{|c|}{$\begin{array}{l}\text { New Lic. } \\
\text { No. \% }\end{array}$} & \multicolumn{2}{|c|}{$\begin{array}{l}\text { New Ph.D. } \\
\text { No. } \%\end{array}$} \\
\hline & & & & & & & & \\
\hline Systems (0) & 66 & 29.7 & 32 & 42.1 & 4 & 9.3 & 27 & 12.3 \\
\hline Economic growth; & & & & & & & & \\
\hline $\begin{array}{l}\text { Development; Plan- } \\
\text { ning; Fluctuations (1) }\end{array}$ & 23 & 10.4 & 4 & 5.3 & 2 & 4.7 & 29 & 13.2 \\
\hline $\begin{array}{l}\text { Quantitative economic } \\
\text { methods and data (2) }\end{array}$ & 8 & 3.6 & 2 & 2.6 & 2 & 4.7 & 9 & 4.1 \\
\hline $\begin{array}{l}\text { Domestic monetary and } \\
\text { fiscal theory and }\end{array}$ & & & & & & & & \\
\hline institutions (3) & 22 & 9.9 & 10 & 13.2 & 3 & 7.0 & 14 & 6.4 \\
\hline International & & & & & & & & \\
\hline economics (4) & 20 & 9.0 & 6 & 7.9 & 5 & 11.6 & 25 & 11.4 \\
\hline $\begin{array}{l}\text { Administration; } \\
\text { Business finance; }\end{array}$ & & & & & & & & \\
\hline Marketing; Accounting (5) & 1 & 0.5 & 0 & 0.0 & 0 & 0.0 & 3 & 1.4 \\
\hline $\begin{array}{l}\text { Industrial organization; } \\
\text { Technological change; }\end{array}$ & & & & & & & & \\
\hline Industry studies (6) & 26 & 11.7 & 8 & 10.5 & 3 & 7.0 & 30 & 13.6 \\
\hline $\begin{array}{l}\text { Agriculture; Natural } \\
\text { resources (7) }\end{array}$ & 9 & 4.1 & 3 & 3.9 & 12 & 27.9 & 34 & 15.5 \\
\hline Manpower; Labour; & & & & & & & & \\
\hline Population (8) & 21 & 9.5 & 8 & 10.5 & 10 & 23.3 & 27 & 12.3 \\
\hline Welfare programmes; & & & & & & & & \\
\hline $\begin{array}{l}\text { Urban and regional } \\
\text { economics (9) }\end{array}$ & 26 & 11.7 & 3 & 3.9 & 2 & 4.7 & 22 & 10.0 \\
\hline Total & $222^{b}$ & 100.0 & 76 & 100.0 & 43 & 100.0 & 220 & 100.0 \\
\hline
\end{tabular}

Source: The table is compiled from a register made for this study.

Notes: "Area numbers according to the system of the Journal of Economic Literature in parentheses.

'The total number is 229 , but as it has not been possible to obtain information on the subjects of 7 theses, these have not been included in this table.

economics'. In many cases they write theses dealing with the economies of their home countries.

\section{THE LABOUR MARKET FOR DOCTORS OF ECONOMICS}

Altogether 220 people have been awarded the new Ph.D. in economics since the start of the system and up to 1990. In November 1990 they 
Recruiting a new generation

Table 4.19 Present occupation (November 1990) according to sector

\begin{tabular}{|c|c|c|c|c|c|c|c|c|c|c|}
\hline $\begin{array}{l}\text { Present } \\
\text { occupation }\end{array}$ & & $J L U$ & $\begin{array}{l}\text { Thes } \\
G U\end{array}$ & $\begin{array}{c}\text { sis at } \\
S U\end{array}$ & $U m U$ & $H H S$ & Other & Total & Men & Women \\
\hline Same university & 8 & 17 & 19 & 15 & 5 & 5 & 8 & 87 & 81 & 6 \\
\hline Other university & 1 & 8 & 1 & 4 & 4 & 11 & 1 & 30 & 28 & 2 \\
\hline $\begin{array}{l}\text { University college } \\
\text { or univ. without } \\
\text { Ph.D. } \\
\text { programmes in }\end{array}$ & & & & & & & & & & \\
\hline $\begin{array}{l}\text { economics } \\
\text { External research }\end{array}$ & 0 & 1 & 5 & 1 & 2 & 0 & 0 & 9 & 7 & 2 \\
\hline institute & 3 & 3 & 2 & 4 & 3 & 5 & 0 & 20 & 18 & 2 \\
\hline $\begin{array}{l}\text { sector } \\
\text { Interest }\end{array}$ & 2 & 3 & 5 & 7 & 4 & 4 & 3 & 28 & 26 & 2 \\
\hline organization & 2 & 1 & 1 & 3 & 0 & 1 & 1 & 9 & 9 & 0 \\
\hline Banks & 1 & 1 & 1 & 4 & 0 & 3 & 0 & 10 & 10 & 0 \\
\hline $\begin{array}{l}\text { Other private } \\
\text { sector }\end{array}$ & 0 & 2 & 1 & 1 & 0 & 2 & 1 & 7 & 7 & 0 \\
\hline Outside Sweden & 7 & 7 & 5 & 7 & 0 & 2 & 3 & 31 & 26 & 5 \\
\hline No information & 0 & 0 & 0 & 0 & 0 & 1 & 0 & 1 & 1 & 0 \\
\hline Total & 24 & 42 & 40 & 45 & 18 & 34 & 17 & 220 & 201 & 19 \\
\hline
\end{tabular}

Source: The table is compiled from a register made for this study.

were all still under retirement age, and it was possible to classify all but one according to the sector of their current employment. A majority of them, 117, were still working at one of the universities which have $\mathrm{Ph} . \mathrm{D}$. programmes. Most of these people, 87 out of 117, were working at the same university where they once took their degree (table 4.19). ${ }^{21}$ Of those who have moved between universities, half did so between the two universities in Stockholm. In Lund and Gothenburg all of the staff who have Swedish $\mathrm{Ph} . \mathrm{D}$. degrees received them from the university where they are employed today. The exchange of research and teaching experiences between Swedish universities is naturally not encouraged by these conditions.

For those who have left the university sphere, research institutes and the public sector are the most common employers. The corresponding role in the private sector is fulfilled by banks and organizations for male economics doctors; no women with this degree are employed in the private sector (organizations, banks, or other private sector). Almost all those working abroad were once foreign students in Sweden who have now returned to their home countries. 


\section{Introduction and background studies}

In considering the factors that determine who stays in the academic world after obtaining a doctor's degree, we decided to concentrate on those who studied at one of the universities offering full Ph.D. programmes (Uppsala, Lund, Gothenburg, Stockholm and Umeå universities, and the Stockholm School of Economics). The most clearly evident result is that those who write a theoretical thesis (area 0) continue to work in the university world to a much greater extent than those who write more empirically oriented theses. It is also clear that those who have their doctoral degrees from a university outside the Stockholm-Uppsala region, tend to be less inclined to leave the university world. Other variables tested - age, gender, form of financial support, time since thesis - show small or negligible differences between those who remain at the university and those who leave. The explanation for the absence of an effect associated with "time since thesis' could be that most people who leave the university probably do so before or just after completing their theses. ${ }^{22}$

It is possible to analyse the earnings of those who have obtained a licentiate or Ph.D. degree since 1970 at one of the universities running general programmes in economics, or at the Stockholm School of Economics, by using data available at Statistics Sweden. In the analysis which was conducted at Statistics Sweden for this chapter, the individual earnings of those living in Sweden in 1989 were used. To

minimize the risk of including people who did not reside in Sweden for the whole year, only those who had earnings in November 1989 were included. The population studied includes 161 people with a $\mathrm{Ph} . \mathrm{D}$. and 42 with a licentiate. ${ }^{23}$

The results are presented in tables 4.20 and 4.21 . Table 4.20 shows the mean and median wage incomes and total earnings for various groups. The sign for the differences between the groups is usually the expected one, but the size of the differences may be higher than expected. Men with a Ph.D. in economics have 27 per cent higher median total earnings than women with the same degree; people born in Sweden have 49 per cent higher median total earnings than those born abroad; and those working in the private sector have 67 per cent higher median total earnings than those working in the public sector.

Note also that earnings increase considerably with the number of years since the degree was obtained, and with age. Earnings are also higher for those who obtained their doctor's degree from the Stockholm School of Economics or from Umeå University. ${ }^{24}$

Note also that those with a Ph.D. from 1970-4 have much higher earnings than those with a licentiate (and no Ph.D.) from the same 
Recruiting a new generation 97

Table 4.20 Wage income and total earnings from employment in 1989 for those who have received a Ph.D. or Licentiate degree in economics in Sweden 1970-89

\begin{tabular}{|c|c|c|c|c|}
\hline & $\begin{array}{l}\text { Mean } \\
\text { wage } \\
\text { income }\end{array}$ & $\begin{array}{l}\text { Median } \\
\text { wage } \\
\text { income }\end{array}$ & $\begin{array}{l}\text { Mean } \\
\text { total } \\
\text { earnings }\end{array}$ & $\begin{array}{l}\text { Median } \\
\text { total } \\
\text { earnings }\end{array}$ \\
\hline $\begin{array}{l}\text { Ph.D. } \\
\text { All } \\
\text { Men } \\
\text { Women }\end{array}$ & $\begin{array}{l}309,500 \\
316,800 \\
219,100\end{array}$ & $\begin{array}{l}267,000 \\
271,100 \\
225,200\end{array}$ & $\begin{array}{l}316,600 \\
323,700 \\
228,000\end{array}$ & $\begin{array}{l}271,100 \\
285,900 \\
226,000\end{array}$ \\
\hline $\begin{array}{l}\text { Age } \\
-34 \\
35-9 \\
40-4 \\
45-9 \\
50-4 \\
55-64\end{array}$ & $\begin{array}{l}193,400 \\
263,000 \\
337,200 \\
298,300 \\
358,200 \\
446,900\end{array}$ & $\begin{array}{l}189,100 \\
256,000 \\
289,600 \\
266,400 \\
316,400 \\
375,100\end{array}$ & $\begin{array}{l}198,800 \\
267,500 \\
341,300 \\
307,200 \\
376,500 \\
469,200\end{array}$ & $\begin{array}{l}195,600 \\
256,000 \\
293,000 \\
269,500 \\
352,700 \\
375,100\end{array}$ \\
\hline $\begin{array}{l}\text { Born in Sweden } \\
\text { Born abroad }\end{array}$ & $\begin{array}{l}325,700 \\
212,000\end{array}$ & $\begin{array}{l}291,000 \\
197,200\end{array}$ & $\begin{array}{l}333,600 \\
214,500\end{array}$ & $\begin{array}{l}294,200 \\
197,200\end{array}$ \\
\hline $\begin{array}{l}\text { Swedish citizens } \\
\text { Foreign citizens }\end{array}$ & $\begin{array}{l}318,200 \\
190,900\end{array}$ & $\begin{array}{l}279,400 \\
177,600\end{array}$ & $\begin{array}{l}325,800 \\
191,100\end{array}$ & $\begin{array}{l}285,400 \\
177,600\end{array}$ \\
\hline $\begin{array}{l}\text { Public sector } \\
\text { Private sector }\end{array}$ & $\begin{array}{l}273,000 \\
439,900\end{array}$ & $\begin{array}{l}252,000 \\
375,000\end{array}$ & $\begin{array}{l}276,600 \\
460,400\end{array}$ & $\begin{array}{l}257,000 \\
430,100\end{array}$ \\
\hline $\begin{array}{l}\text { UU } \\
\text { LU } \\
\text { GU } \\
\text { SU } \\
\text { UmU } \\
\text { HHS }\end{array}$ & $\begin{array}{l}246,600 \\
298,600 \\
272,300 \\
294,600 \\
335,200 \\
403,100\end{array}$ & $\begin{array}{l}238,000 \\
250,800 \\
239,500 \\
267,600 \\
353,400 \\
357,500\end{array}$ & $\begin{array}{l}250,700 \\
301,400 \\
274,800 \\
300,500 \\
339,200 \\
423,500\end{array}$ & $\begin{array}{l}241,700 \\
270,400 \\
243,000 \\
273,400 \\
364,200 \\
367,700\end{array}$ \\
\hline $\begin{array}{l}\text { Year of examinat } \\
1970-4 \\
1975-9 \\
1980-4 \\
1985-9\end{array}$ & $\begin{array}{l}433,200 \\
351,200 \\
316,500 \\
217,500\end{array}$ & $\begin{array}{l}387,000 \\
293,600 \\
304,800 \\
193,100\end{array}$ & $\begin{array}{l}440,900 \\
362,800 \\
320,100 \\
221,900\end{array}$ & $\begin{array}{l}405,300 \\
296,600 \\
306,700 \\
201,000\end{array}$ \\
\hline $\begin{array}{l}\text { Old Lic } \\
(1970-4)\end{array}$ & 266,500 & 258,600 & 272,600 & 259,900 \\
\hline $\begin{array}{l}\text { New Lic } \\
(1985-9)\end{array}$ & 162,800 & 157,800 & 164,900 & 161,800 \\
\hline
\end{tabular}

Source: Computations made at Statistics Sweden, Orebro for this study, Data from the Register of Yearly Earnings ('ÅRSYS') and the Research Student Register ('Högskoleregistret').

Note: 'Only those who have not received a $\mathrm{Ph} . \mathrm{D}$. are included among those with a Lic. 


\section{Introduction and background studies}

Table 4.21 Earnings equations. Earnings in 1989 for those who have received a Ph.D. in economics in Sweden 1970-89

\begin{tabular}{|c|c|c|c|c|c|c|c|c|}
\hline & $\ln W^{a}$ & $\ln W$ & $\ln W$ & $\ln W^{b}$ & $\ln E$ & $\ln E$ & $\ln E$ & $\ln E^{b}$ \\
\hline & $\begin{array}{l}90 \\
21)\end{array}$ & $\begin{array}{c}11.951 \\
(.234)\end{array}$ & $\begin{array}{c}12.212 \\
(.125)\end{array}$ & $\begin{array}{r}12.3 \\
(.0\end{array}$ & $\begin{array}{r}12.162 \\
(.115)\end{array}$ & $\begin{array}{l}04 \\
20)\end{array}$ & $\begin{array}{c}12.189 \\
(.121)\end{array}$ & \\
\hline Age-25 & $\begin{array}{c}.0016 \\
(.0063)\end{array}$ & $\begin{array}{l}.019 \\
(.023)\end{array}$ & $\begin{array}{c}.0029 \\
(.0064)\end{array}$ & $\begin{array}{c}.0023 \\
(.0050)\end{array}$ & $\begin{array}{c}.005 \\
(.006)\end{array}$ & $\begin{array}{c}.023 \\
(.022)\end{array}$ & $\begin{array}{c}.007 \\
(.006)\end{array}$ & $\begin{array}{l}.0016 \\
(.0047)\end{array}$ \\
\hline a & & $\begin{array}{l}-.0003 \\
(.0006)\end{array}$ & & & & $\begin{array}{l}-.0004 \\
(.0005)\end{array}$ & & \\
\hline $\begin{array}{l}\text { Years } \\
\text { since } \\
\text { exam }\end{array}$ & & $\begin{array}{c}.062 \\
(.022)\end{array}$ & $\begin{array}{c}.036 \\
(.008)\end{array}$ & & $\begin{array}{c}.028 \\
(.007)\end{array}$ & $\begin{array}{c}.061 \\
(.021)\end{array}$ & & $\begin{array}{c}.022 \\
(.005)\end{array}$ \\
\hline $\begin{array}{l}\text { (Years } \\
\text { since } \\
\text { exam) }\end{array}$ & & $\begin{array}{l}-.00 \\
(.00\end{array}$ & & & & & & \\
\hline & & & & & & & & \\
\hline $\begin{array}{l}\text { Born } \\
\text { Abroad }\end{array}$ & & & $\begin{array}{l}-.210 \\
(.092)\end{array}$ & & & & & $\begin{array}{l}-.248 \\
(.066)\end{array}$ \\
\hline $\begin{array}{c}\text { Private } \\
\text { Sector }\end{array}$ & & $\begin{array}{c}.268 \\
(.078)\end{array}$ & & & & & & \\
\hline UI & $\begin{array}{l}-.183 \\
(.112)\end{array}$ & $\begin{array}{l}-.180 \\
(.111)\end{array}$ & $\begin{array}{l}-.151 \\
(.115)\end{array}$ & & -.1 & & & \\
\hline LU & & & $\begin{array}{c}.042 \\
(.093)\end{array}$ & & & & & \\
\hline GU & & & -.052 & & & & & $\begin{array}{l}-.056 \\
(.066)\end{array}$ \\
\hline $\mathrm{UmU}$ & $\begin{array}{c}.222 \\
(.134)\end{array}$ & $\begin{array}{c}.224 \\
(.134)\end{array}$ & $\begin{array}{l}.185 \\
(.137)\end{array}$ & $\begin{array}{l}.160 \\
(.102)\end{array}$ & $\begin{array}{c}.230 \\
(.126)\end{array}$ & $\begin{array}{l}.233 \\
(.126)\end{array}$ & $\begin{array}{c}.186 \\
(.132)\end{array}$ & $\begin{array}{c}.162 \\
(.098)\end{array}$ \\
\hline HHS & $\begin{array}{l}.168 \\
(.093)\end{array}$ & $\begin{array}{l}.176 \\
(.093)\end{array}$ & $\begin{array}{l}.179 \\
(.096)\end{array}$ & $\begin{array}{c}.091 \\
(.074)\end{array}$ & $\begin{array}{l}.236 \\
(.088)\end{array}$ & $\begin{array}{l}.246 \\
(.088)\end{array}$ & $\begin{array}{l}.250 \\
(.092)\end{array}$ & $\begin{array}{l}.113 \\
(.069)\end{array}$ \\
\hline III & 16 & 161 & 161 & 151 & 161 & 161 & 161 & 151 \\
\hline $\mathbf{R}$ & & .361 & .351 & .3 & .407 & .418 & .348 & .438 \\
\hline$\Gamma$ & 9.795 & 8.538 & 9.162 & 10.868 & 12.002 & 10.576 & 10.480 & 12.671 \\
\hline
\end{tabular}

Source: Computations made at Statistics Sweden, Orebro for this study. Data from the registers 'ARSYS' and 'Högskoleregistret'.

Notes: " $\mathrm{W}=$ Wage income, $\mathrm{E}=$ Income from employment (includes earnings from self-employment and transfer income related to employment). Standard errors in parentheses.

${ }^{b}$ Truncated sample excluding those with the five highest and the five lowest incomes.

period. The former group have on an average 56 per cent higher total earnings. The difference cannot of course be used directly to calculate the value of a $\mathrm{Ph} . \mathrm{D}$. compared with a licentiate degree, as there is probably a selection process. 
The earnings of those with Ph.D. degrees in economics or business administration are higher than the earnings of any other social science doctors. Their earnings are $30-40$ per cent higher than those of their counterparts in other disciplines. If the earnings of the economics doctors are compared with their equivalents in other faculties, the general pattern is the same. Those with $\mathrm{Ph} . \mathrm{D}$. degrees in economics have higher earnings. The only exceptions are the doctors of medicine, whose earnings are roughly 15 per cent higher, and those with doctorates in law, who enjoy the same earnings as the economists (see Wadensjö, 1991).

A study of the variables one by one may be misleading. The low incomes of the foreign-born, for example, may depend on their being younger and having obtained their degrees more recently than their Swedish-born counterparts. Earnings equations have therefore been estimated (see table 4.21). The dependent variable is either yearly wage income or total yearly earnings. Explanatory variables are age, gender, years since examination, sector of employment, and the university which awarded the degree. Four estimated equations are shown for each dependent variable. In the fourth equation for each dependent variable the observations with the five highest and five lowest incomes are excluded, to check whether the results are highly dependent on a few extreme cases. This proved not to be the case, so the following comments refer to the estimations with all observations included.

In general the regression analyses reveal much the same sized differences as the comparisons of the median incomes discussed above. Women economists have around 25-30 per cent lower earnings than their male colleagues, and immigrants about 20 per cent lower earnings than their Swedish-born counterparts. Note that the differences are somewhat higher when the private-sector variable is excluded than when it is included. The lower earnings of women and immigrants depend to some extent on their underrepresentation in the higher-paying private sector, but mainly on the fact that they receive lower earnings in both sectors.

Those working in the private sector get higher pay than those working in the public sector. The difference, however, is only about 25-30 per cent, or much less than the figures for mean and median earnings shown in table 4.20.

In studying the effects of reading at one university rather than another, Stockholm University students were used as the reference group. The coefficients thus show the difference as compared to Stockholm University. The estimations all give about the same order between the universities. Those with Ph.D. degrees from the 
Stockholm School of Economics and Umeå University have the highest earnings, and those from Uppsala University the lowest. The other three universities belong to an intermediate group. The differences are not neglible, and in all the estimations earnings are significantly higher for those from the Stockholm School of Economics than for those from Uppsala University. Note, however, that since individual students are not randomly distributed among the universities but have themselves selected which university to attend, there may be a selection bias in the earnings equation.

Perhaps the most interesting result is that if both variables are included, time since examination, but not age, helps to explain the distribution of earnings. The age variable is always insignificant if the length of time since the examination is included, and the latter is always highly significant. The value of its coefficient is $c .0 .03$ if it is only included in its linear form (the quadratic term, if included, is not significant). This means that earnings are 3 per cent higher for each year that has passed since the examination, and that this is not explained by a general age effect. This underlines the importance of completing the $\mathrm{Ph}$.D. programme early. Note that the maximum value of the years passed since the examination is 19 in this data set. The linear form of the variable may prove a less satisfactory representation when it becomes possible to cover a longer time period.

According to estimations using information about the earnings of the same people for both 1986 and 1989, the increase in (nominal) earnings between the two dates was 109 per cent for those who obtained their Ph.D. degrees in the period 1986 to 1989. This result could be compared with an average increase of 52 per cent in the same period for those who received their degrees before 1986. This does not support the view that there are no economic gains to be had from a Ph.D. in economics.

In estimations not shown here dummies were included for the new and the old licentiate degree as the highest degree in a combined population of all those obtaining research degrees in economics between 1970 and 1989 . The dummies are highly significant with very high values. However, the results may be misleading as there is a problem of multicollinearity. The dummies are highly correlated with some of the other explanatory variables.

In earlier sections of this chapter the large inflow into postgraduate programmes at the start of the new system, the tendency to embark on postgraduate studies at a later date, and the gradually increasing length of the study period have all been discussed. These three factors together mean that most of those who have received a Ph.D. in 


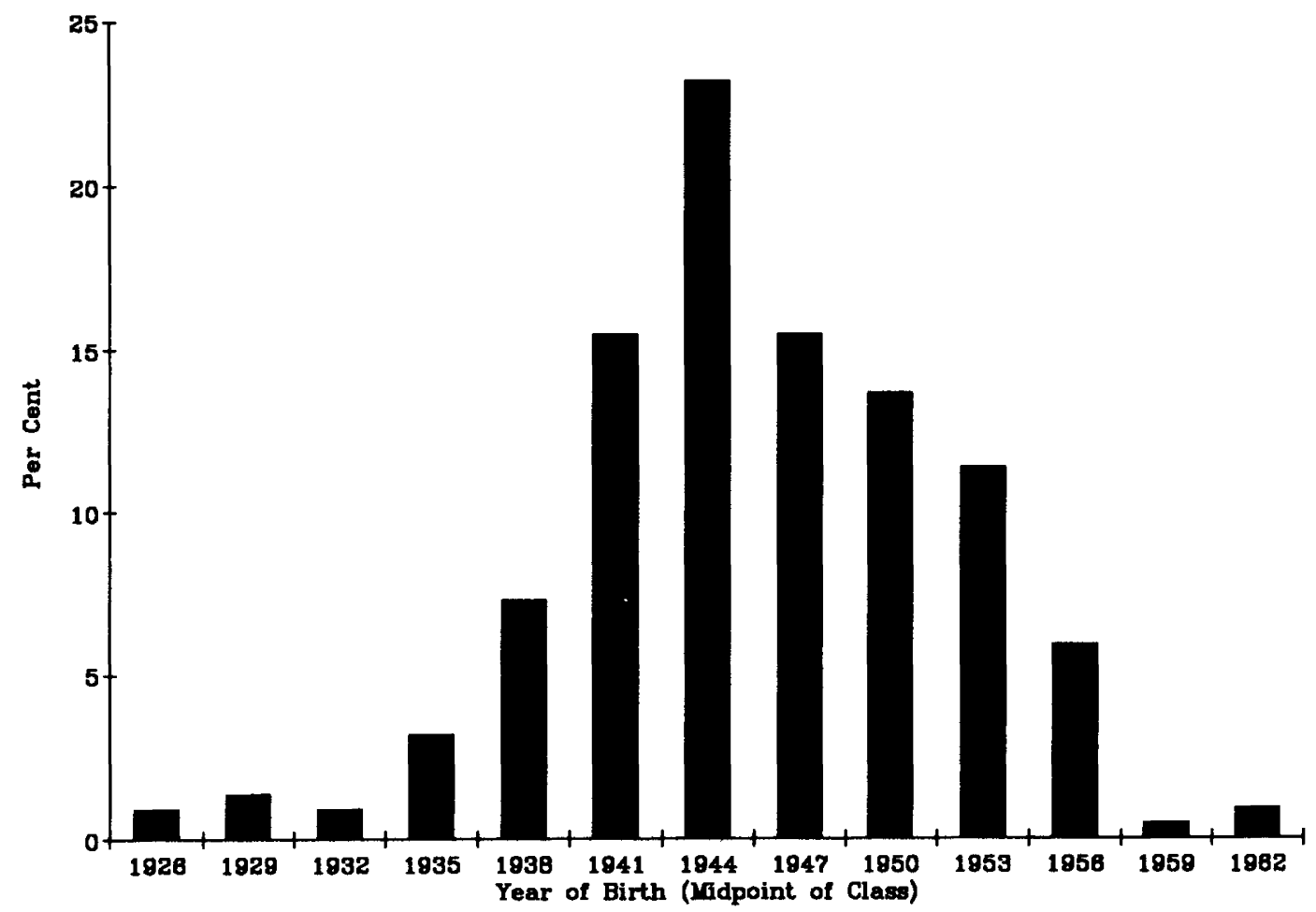

Figure 4.1 Histogram over year of birth of those granted a Ph.D. in economics 1970-89 Source: The figure is based on a register made for this study 


\section{Introduction and background studies}

economics were born in the 1940s (figure 4.1). Of those holding a Ph.D., 57 per cent were born between 1940 and 1949. By extending the period slightly at both ends, from 1938 to 1953, we find that the figure increases to 83 per cent.

The uneven age distribution may have some career consequences. Those who are completing their degrees now may find it very difficult to acquire posts at the universities unless the number of positions continues to increase. On the other hand, between 2005 and 2015, most of those holding a doctor's degree and employed at a university will retire, which will probably lead to a period of good employment prospects.

\section{CONCLUSIONS}

The new Ph.D. system has now been in force for two decades. It is possible to make a rough evaluation of the system.

1 The inflow of students into postgraduate programmes in economics has been stable since the large inflow at the start of the system. It has been difficult to recruit research students directly after the completion of their undergraduate studies, however, especially in Stockholm. It has been easy for graduates to find employment immediately after obtaining their first degree. The current downturn in the economy may mean that more students move on immediately to research studies at this stage.

2 There are more completed theses under the new system than under the earlier one (the old licentiate and the old Ph.D.), but there are still not many if their numbers are related to the number of people registering as research students. Most students break off their postgraduate studies without presenting a thesis. The recently reintroduced licentiate degree may provide a way of getting more students to complete their postgraduate studies, though not perhaps to $\mathrm{Ph}$.D. level. A new rule (introduced by collective agreement in 1991) will make it more difficult for a research student to get economic support from or to be employed by the university for more than four years, and this may force more students to break off their studies without a degree.

3 The age of those being awarded the new Ph.D. degree is not only higher than under the earlier system; it is also gradually rising. A current trend towards providing financial support at an early stage in the postgraduate studies and towards shorter theses consisting of unpublished articles may reduce the time spent on Ph.D. studies.

4 Nine out of ten of those presenting a thesis in economics are men. 
The percentage of women is higher among those who receive the new licentiate degree than those getting a Ph.D., but even here men are in the majority (four out of five). One reason for this may be that there are very few female thesis advisers. No woman economist has ever held a chair in economics. Karin Kock was acting professor at Stockholm University between 1938 and 1946 and was awarded the title of professor in 1945 but she never got a chair.

5 The trend has been for theses to be written in English. This is in accordance with the intentions underlying the new system. An exception to this trend is that most Ph.D. theses written by women students are in Swedish.

6 To an ever increasing extent faculty opponents are being chosen from outside the candidate's university and even from outside Sweden; Denmark, Norway, the United Kingdom and the United States are the four main sources. This tendency towards equating the role of the opponent with that of an external examiner is also in accordance with the intentions of the reform of the system.

7 The theses cover a wide range of subjects. However, all universities are more or less specialized in a few areas. Industry studies at Gothenburg University and labour economics at Umeå University are two examples. The Ph.D. theses written by women economists are overrepresented in applied economics, especially in labour economics, compared to those written by their male counterparts. Many foreign students have written theses in the field of development economics.

8 The earnings of economists holding $\mathrm{Ph} . \mathrm{D}$. degrees reveal considerable variations. Earnings are higher, the more time has passed since examination. Women and immigrant economists have lower earnings than their male and Swedish-born counterparts. Those working in the private sector have higher earnings than those in the public sector, and there are also differences in earnings between those receiving their $\mathrm{Ph} . \mathrm{D}$. degrees from different universities.

9 The vast majority of Swedish economists were born in the 1940s and early 1950s. This means that there will be relatively few vacant positions at the universities in the 1990s but many from about 2005 onwards. This is very likely to influence the labour market prospects of those taking a doctoral degree in economics. 


\title{
5 Swedish economics on the international scene
}

\author{
Olle Persson, Peter Stern and Elving Gunnarsson
}

\section{INTRODUCTION}

Swedish economics appears in the international arena in personal form, in the shape of economists attending conferences or serving as guest researchers or lecturers, and in written form in the shape of contributions to internationally available publications. Although personal contacts and relations are of fundamental importance, we will concentrate here on the presence of Swedish economics in the international publishing market. A major reason for investigating this market is that the publication of research findings plays a major role in almost every field of scientific activity - the field of economics is no exception. Publication serves several purposes. For one thing, it is probably the only way for the individual scientist to establish priority for any discoveries. Since modern science is international, and any subfield may include researchers from around the globe, publication in scholarly journals is a necessary prerequisite for the scientific discourse. Without a system of formalized communication, science would cease to exist as an organized activity for the development of knowledge. In a small country like Sweden international communication through formal and informal channels is of particular importance, since most of the relevant colleagues of a Swedish scientist are active abroad. Furthermore, a study of journal articles implies a quality filter, since the manuscripts have been examined by referees before publication.

The field of scientific publications consists of two main markets, the market for monographs and the journal market. As the journal market is of great importance to the international exchange of research results and the economics debate, we have focused our main interest on that market, although some aspects of the monograph markets will also be mentioned.

Line (1979) gave some indication of the role of the journal market in 
economics. He found that 44 per cent of the citations in economic journals referred to previous journal articles. The corresponding figure for sociology was 34 per cent and for political science 21 per cent. Further indication of the relative and growing importance of the journal market in economics emerged in the course of our own study. We looked at Swedish articles in economics published between 1972 and 1989 and found that in the 100 latest articles 50 per cent of the references referred to journal items, while the corresponding figure for the 100 earliest articles was only 39 per cent. Although a large proportion of all economic literature is still published in monographs and report series, the journal market is clearly a significant arena for an evaluation of Swedish economics.

There are some factors militating against publication in international journals. Compared to the natural sciences, the social sciences are commonly regarded as less universal and less internationally orientated. There is often limited consensus about theories and interpretations; some theories cannot be verified or nullified and fashion plays an influential part. Furthermore, many research problems and much data may be of little relevance to an international public. For example, the nationally oriented reports of Swedish government committees are seldom published in international journals, and consequently fall outside the focus of this investigation.

None the less, the journal market is of great importance to the international exchange of research results and debate. When a manuscript is sent to a scientific journal the referees may suggest valuable improvements, and this serves as a kind of quality filter. When the article is published the author(s) may receive praise and criticism, which can be valuable to further research. From the point of view of the research community and the development of knowledge it is vital that research results should be as easily available as possible. If research results are not presented to the international audience, then important findings may be overlooked, research may be duplicated, or disputes arise about priority.

The purpose of our investigation is to provide an overview of the main features of Swedish economics and Swedish economic institutions, as they appear in the international publishing markets. The chronological development of Swedish economics as a whole will be investigated, and some comparisons will be made with economics in other countries. Attempts will also be made to find characteristic features of the main Swedish research institutions in economics. 


\section{Introduction and background studies}

\section{DATA MATERIAL}

In evaluating a national scientific community such as economics in Sweden, a bibliometric analysis may indicate something about the visibility, impact and orientation of research. Even though a great many factors may affect the publication counts, such as language barriers, traditions, degree of basic research, etc, the counts may still offer a general indication of the health of the national system and serve as a starting-point for a more thorough evaluation. A bibliometric approach is not only suitable as a way of quantifying scientific output; it can also be used for mapping the subfield structure of a scientific discipline.

For this study we used the online version of the Social Science Citation Index (SSCI), Social Scisearch, which covers 120 journals in economics. In many fields in the SSCI, American journals are overrepresented. In economics, however, the major journals in the field seem to be included, at least as Swedish economists would see it. The Journal of Economic Literature, which is also an online database, has a somewhat broader coverage, but this database is not suited to our purposes since it lacks information on the authors' addresses and does not contain citations. The Social Scisearch contains the corporate sources of all the authors of an article. This is an important feature, since an increasing number of articles are institutionally co-authored. Furthermore, each source item is classified as a genuine article, review, note, letter, book review, etc. It seems most appropriate to count genuine articles, since they usually contain concrete research findings. The bibliographic record has a language code which makes it possible to distinguish between articles written in Swedish and English. About 95 per cent of the Swedish articles in economics are written in English and 3.5 per cent are published in the Swedish language. Most of the remaining articles are written in another Nordic language, while one or two only are written in German, French, Italian or Spanish. Each record also contains a full reference list in which citations to all document types are recorded.

Several indicators can be derived from this kind of data. With the help of the bibliographic record we are able to locate a paper in at least five dimensions: content, time, space, channel and actor. The article was written about something (content), published during a given year (time), in a given journal (channel), written at a certain location (space) by somebody (actor). This means that we may compare, among other things, the publication activity of various countries in economics in the period, 1973-89. We are able to describe the distribution of articles by individuals, institutions or scientific 
subfields. The selection of journals for publication can be studied in great detail, and by using citations we may get an indication of the visibility of these journals within the international journal market. The citations could also be used for describing how national research communities are related to the intellectual heritage, or for finding a basis for characterizing national research profiles.

The journals covered by Social Scisearch are classified in subject categories. By counting the number of Swedish articles in economic journals, we can study the visibility of Sweden in a specific segment of the journal market. In an evaluation context we assume that it is of some importance for Sweden to be present on that market. But it must be stressed that the articles may have been written by researchers from fields other than economics. On the other hand Swedish economists may publish articles in journals not belonging to the class of economic journals. In order to get complementary information on the visibility of Swedish economists, we scanned the reference lists of the volumes of the Handbook of Economics.

\section{PUBLICATION ACTIVITY AND JOURNAL SELECTION}

If we count articles written in English in journals belonging to the economics journal category of SSCI in 1989, Sweden accounts for about 1.1 per cent of world output, France about 1.4 per cent and the former West Germany 2.6 per cent (figure 5.1).

All three countries have increased their share since the middle of the 1970s, though Sweden a little less than the others. One might ask whether this growth is due to an increase in research activity or to a more pronounced Anglo-Saxon orientation. In absolute numbers Sweden produces only about fifty articles per year (table 5.1). On the other hand, if we relate the number of articles to the population of each country, Sweden is far more productive than France or West Germany. During the period 1973-89 Sweden produced about 150 articles per million inhabitants between the ages of 25 and 65, while the corresponding figure for West Germany was about 40 and for France about 30.

If we assume that the number of researchers in economics approximately equals the number of authors to Swedish journal articles in economics, then there are about 350 of them (table 5.2). This means that a Swedish researcher in this field produces on an average one article every seventh year in an international journal. It is also interesting to note that Sweden's share of the international publication market in economics is not decreasing, and that it is similar to the 


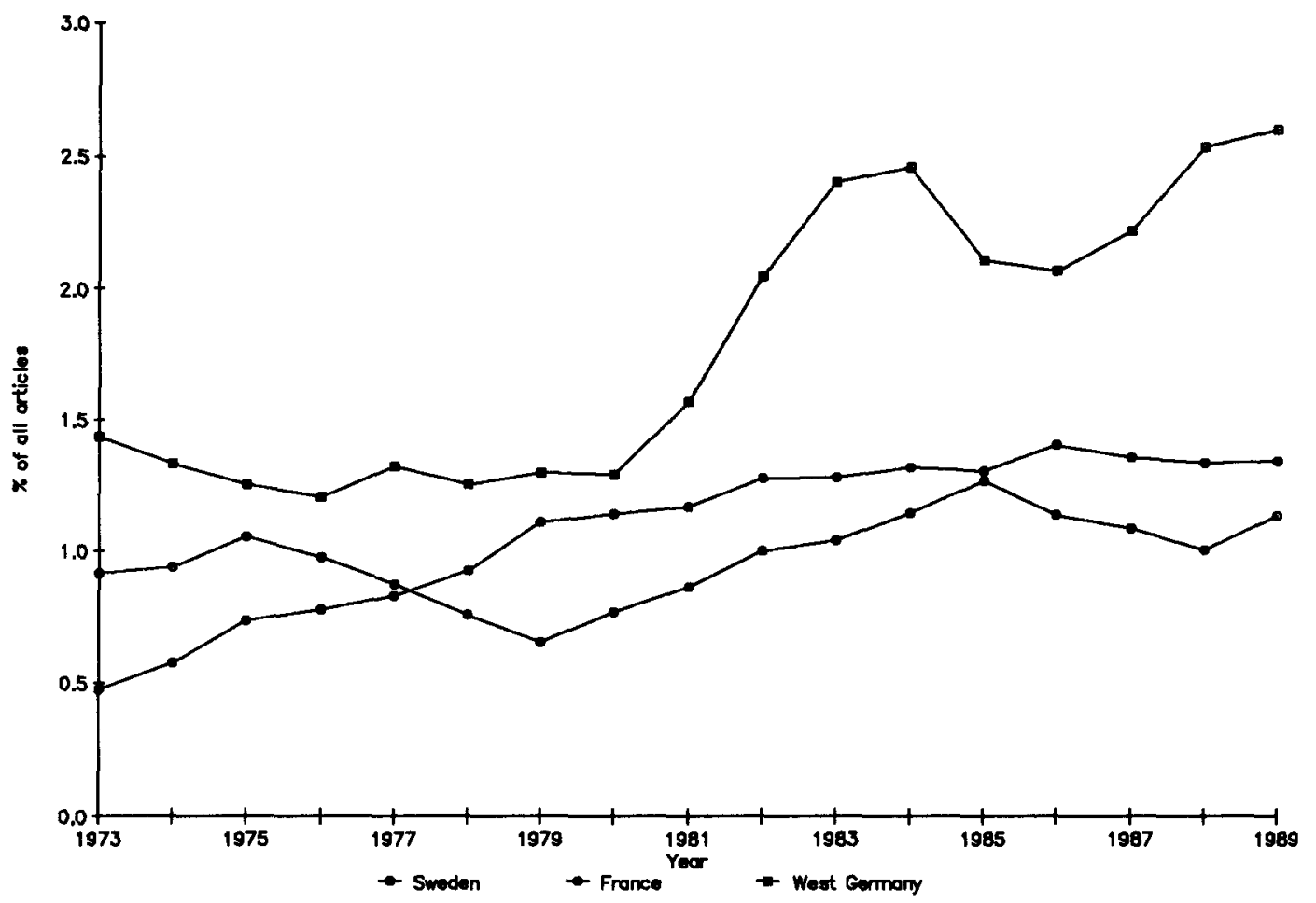

Figure 5.1 Percentage share of world output of articles written in English in economic journals 1973-89 - Sweden, West Germany and France, three-year weighted averages Source: Inforsk, Social Seisearch via Dialog. 
Table 5.1 Articles written in English in economic journals 1973-89 - Sweden, West Germany and France

\begin{tabular}{lrrrr}
\hline Year & Sweden & France & West Germany & All papers \\
\hline 1973 & 17 & 11 & 37 & 2,392 \\
1974 & 32 & 14 & 38 & 2,866 \\
1975 & 28 & 22 & 32 & 2,841 \\
1976 & 35 & 31 & 43 & 3,293 \\
1977 & 30 & 21 & 40 & 3,390 \\
1978 & 24 & 33 & 53 & 3,570 \\
1979 & 26 & 45 & 40 & 3,658 \\
1980 & 21 & 43 & 48 & 3,653 \\
1981 & 38 & 38 & 55 & 3,750 \\
1982 & 39 & 51 & 75 & 3,887 \\
1983 & 43 & 66 & 120 & 4,376 \\
1985 & 59 & 64 & 94 & 4,485 \\
1984 & 49 & 44 & 109 & 4,302 \\
1986 & 59 & 64 & 74 & 4,368 \\
1987 & 33 & 59 & 107 & 4,445 \\
1988 & 53 & 58 & 116 & 4,550 \\
1989 & 51 & 65 & 122 & 4,613 \\
\hline
\end{tabular}

Source: Inforsk, Social Scisearch via Dialog.

world share in physics, chemistry and engineering (Persson 1988). It should be stressed that there are some Swedish economists who have not published in the group of journals selected for this study.

In economics, as in most other fields of science, the distribution of papers by author is highly skewed, according to Lotka's law (Lotka 1926). This means that the majority of authors publish at most one paper. If we select all genuine articles published in journals of economics and business finance written in Sweden during the period 1973-89, we find that 75 per cent of the authors produced one or two papers (table 5.2). On the other hand there is one author (Lars E.O. Svensson) who has published forty-one articles, and another one (Assar Lindbeck) twenty-nine. For the majority of Swedish researchers in this field publication in international journals seems however to be the exception rather than the rule.

Another interesting approach is to look more closely into the journal selection behaviour of Swedish economists. In Social Scisearch about 120 journals are listed in economics and another 40 in business finance. If we distribute the Swedish articles published during 1973-89 by journal, Swedes have published at least one article in 89 of these journals (table 5.3). This broad scatter is of course a reflection of the degree of specialization of economics. 


\section{Introduction and background studies}

Table 5.2 Distribution of authors by number of articles in Swedish economics 1973-89

\begin{tabular}{cc}
\hline Number of articles & Number of authors \\
\hline 41 & 1 \\
29 & 1 \\
19 & 1 \\
18 & 1 \\
16 & 1 \\
14 & 2 \\
13 & 2 \\
12 & 2 \\
11 & 3 \\
10 & 2 \\
9 & 2 \\
8 & 6 \\
7 & 1 \\
6 & 6 \\
5 & 14 \\
4 & 17 \\
3 & 29 \\
2 & 58 \\
1 & 219 \\
\hline
\end{tabular}

Source: Inforsk, Social Scisearch via Dialog.

If we look at the impact of the various journals it is quite obvious that most of the articles are published in much-cited and influential series. A large number of articles are published in the Scandinavian Journal of Economics, which despite its regional links seems to be fairly visible among the most important journals in economics. According to a study of citations in 26 core journals of economics, it is among the 35 most cited (Garfield 1989).'

To be able to compare the journal selection behaviour of Swedish economists with that of their colleagues in other countries, we can study the extent to which articles in economics are published in core journals. If we use Garfield's classification of core journals (Garfield 1989) we find that 36 per cent of the Swedish articles are published in these journals. The corresponding figures for the USA and UK are 35 and 34 per cent (table 5.4). This means that Swedish economists have much the same strategy in terms of publishing in distinguished journals as their Anglo-Saxon colleagues. Another interesting observation is that French economists concentrate on core journals when they publish in English: more than 50 per cent of their English articles are published in such journals. German economists, on the other hand, 
tend to be less apt to publish in core journals. Needless to say, these conclusions are dependent on the classification of core journals, which may seem to possess a certain arbitrariness.

A common assumption is that researchers send their manuscripts to the most prestigious journals. If the manuscript is refused it is sent to a succession of journals according to a status scale, until the article is accepted. This strategy of reward maximization is more of a theoretical construction than an empirical fact. Gordon (1984) showed that scientists primarily choose journals with a view to reaching the relevant audience consisting of researchers in the same subfield. The journal's policy and editorial make-up is more relevant to the choice of journal than the effects that publication may have in terms of citation rates and prestige. If the aim is to maximize visibility and citation scores, Swedish economists could be recommended to send their manuscripts to high-impact journals. If, on the other hand, the goal is to reach a relevant audience, a much broader range of journals is needed. The Swedish publication output seems to have a reasonable proportion of articles in core journals.

A more direct indication of the impact of Swedish economics could be achieved by counting the citations to Swedish authors. To be able to do this in a reliable manner we would have to start with a set of documents written by Swedes. If we just count the number of citations to a specific author name, we have no means of controlling the problem of multi-authorship, since only the first author of a cited document is registered. Furthermore, we run the risk of confusing people with the same name or of neglecting spelling variants of the same author name. We have not therefore made a complete list of citations to Swedish economists, although some of the more cited authors can be indicated with a certain degree of confidence.

Yet another way of estimating the demand for Swedish economics is to investigate the established series of Handbooks in Economics, published by North Holland. There are ten handbooks divided over twenty-one volumes and covering the main fields of economics, although some areas have not yet been covered. The Handbook series has been published from 1981 onwards. This means that some of the Handbooks cover the research situation more than ten years ago. However, most of the chapters in the Handbooks provide extensive surveys of the relevant literature in a specific area from the date of publication. The presence of Swedish monographs or articles in these surveys indicates the visibility of Swedish economics to experts in the field. The lists of references in each chapter have been examined and the number of references containing at least one Swedish author have 


\section{Introduction and background studies}

Table 5.3 Distribution of Swedish articles by journal during 1973-89

\begin{tabular}{|c|c|c|c|}
\hline Title of journal & Number & $\begin{array}{l}\text { Impact } \\
\text { factor }\end{array}$ & Impact \\
\hline Scandinavian Journal of Economics & 156 & 0.4 & 62.4 \\
\hline American Economic Review & 23 & 1.6 & 36.8 \\
\hline Journal of Political Economy & 13 & 2.2 & 28.6 \\
\hline European Economic Review & 35 & 0.5 & 17.5 \\
\hline Journal of International Economics & 19 & 0.9 & 17.1 \\
\hline Journal of Public Economics & 23 & 0.7 & 16.1 \\
\hline Economic Journal & 13 & 1.2 & 15.6 \\
\hline Econometrica & 9 & 1.6 & 14.4 \\
\hline Journal of Economics & 15 & 0.9 & 13.5 \\
\hline Journal of Economic Literature & 3 & 4.3 & 12.9 \\
\hline Regional Science and Urban Economics & 27 & 0.4 & 10.8 \\
\hline Journal of Monetary Economics & 7 & 1.4 & 9.8 \\
\hline Quarterly Journal of Economics & 8 & 1.2 & 9.6 \\
\hline World Development & 16 & 0.6 & 9.6 \\
\hline Accounting Organizations and Society & 13 & 0.5 & 6.5 \\
\hline Economica & 8 & 0.8 & 6.4 \\
\hline Economic Geography & 7 & 0.8 & 5.6 \\
\hline Public Choice & 10 & 0.5 & 5.0 \\
\hline Energy Economics & 12 & 0.4 & 4.8 \\
\hline International Economic Review & 8 & 0.6 & 4.8 \\
\hline Journal of Economic Theory & 6 & 0.8 & 4.8 \\
\hline Oxford Economic Papers & 9 & 0.5 & 4.5 \\
\hline Kyklos & 8 & 0.5 & 4.0 \\
\hline Review of Economics and Statistics & 5 & 0.8 & 4.0 \\
\hline Economics Letters & 18 & 0.2 & 3.6 \\
\hline Weltwirtschaftliches Archiv & 9 & 0.4 & 3.6 \\
\hline Journal of Development Economics & 8 & 0.4 & 3.2 \\
\hline Journal of Urban Economics & 5 & 0.7 & 3.5 \\
\hline Review of Economic Studies & 3 & 1.1 & 3.3 \\
\hline Economic Inquiry & 5 & 0.6 & 3.0 \\
\hline World Economy & 6 & 0.5 & 3.0 \\
\hline Journal of Transport Economics and Policy & 9 & 0.3 & 2.7 \\
\hline History of Political Economy & 8 & 0.3 & 2.4 \\
\hline Journal of Money Credit and Banking & 3 & 0.8 & 2.4 \\
\hline Journal of Economic Psychology & 7 & 0.3 & 2.1 \\
\hline Canadian Journal of Economics & 4 & 0.5 & 2.0 \\
\hline Journal of Economic Issues & 4 & 0.5 & 2.0 \\
\hline Journal of Labor Economics & 2 & 1.0 & 2.0 \\
\hline Review of Income and Wealth & 5 & 0.4 & 2.0 \\
\hline Journal of Economic Behavior \& Organization & 6 & 0.3 & 1.8 \\
\hline Journal of Human Resources & 2 & 0.9 & 1.8 \\
\hline Journal of International Money and Finance & 3 & 0.6 & 1.8 \\
\hline Journal of Law \& Economics & 1 & 1.8 & 1.8 \\
\hline
\end{tabular}


Table 5.3 Continued

\begin{tabular}{lrrr}
\hline & \multicolumn{3}{c}{ Impact } \\
Title of journal & Number & factor & Impact \\
\hline Economist & 1 & 1.7 & 1.7 \\
Journal of Econometrics & 2 & 0.8 & 1.6 \\
Cambridge Journal of Economics & 2 & 0.7 & 1.4 \\
Explorations in Economic History & 2 & 0.7 & 1.4 \\
Journal of Finance & 1 & 1.2 & 1.2 \\
Rand Journal of Economics & 1 & 1.2 & 1.2 \\
Tijdschrift voor Economische en Sociale & & & \\
Geografie & 3 & 0.4 & 1.2 \\
World Bank Economic Review & 1 & 1.2 & 1.2 \\
Economic Development and Cultural Change & 2 & 0.5 & 1.0 \\
Jahrbuch für Nationalökonomie und Statistik & 2 & 0.2 & 1.0 \\
Journal of Environmental Economic & & & \\
Management & 2 & 0.5 & 1.0 \\
Journal of Industrial Economics & 2 & 0.5 & 1.0 \\
Social Choice and Welfare & 3 & 0.3 & 0.9 \\
Journal of Accounting Research & 1 & 0.8 & 0.8 \\
Oxford Bulletin of Economics and Statistics & 2 & 0.4 & 0.8 \\
Accounting Review & 1 & 0.6 & 0.6 \\
Australian Economic Papers & 3 & 0.2 & 0.6 \\
Journal of Comparative Economics & 1 & 0.6 & 0.6 \\
Journal of Economic Dynamics \& Control & 2 & 0.3 & 0.6 \\
Land Economics & 1 & 0.6 & 0.6 \\
Public Finance & 3 & 0.2 & 0.6 \\
Journal of Post Keynesian Economics & 1 & 0.5 & 0.5 \\
Soviet Studies & 1 & 0.5 & 0.5 \\
Applied Economics & 2 & 0.2 & 0.4 \\
Areuea Journal & 1 & 0.4 & 0.4 \\
Economic Record & 2 & 0.2 & 0.4 \\
Economic and Social Review & 2 & 0.2 & 0.4 \\
Journal of Agricultural Economics & 1 & 0.4 & 0.4 \\
Manchester School of Economics Social & 1 & 0.4 & 0.4 \\
Studies & 1 & 0.3 & 0.3 \\
Food Policy & 1 & 0.3 & 0.3 \\
Insurance Mathematics \& Economics & 1 & 0.3 & 0.3 \\
Journal of Macroeconomics & 1 & 0.3 & 0.3 \\
Journal of Risk and Insurance & 3 & 0.1 & 0.3 \\
Trimestre Economico & 2 & 0.1 & 0.2 \\
Developing Economies & 1 & 0.2 & 0.2 \\
Economic Modelling & 1 & 0.2 & 0.2 \\
Ekonomicko-Matematicky Obzor & 1 & 0.2 & 0.2 \\
Hitotsubashi Journal of Economics & 1 & 0.2 & 0.2 \\
International Journal of Social Economics & 1 & 0.2 & 0.2 \\
Nationaløkonomisk Tidsskrift & & & \\
\hline & &
\end{tabular}




\section{Introduction and background studies}

Table 5.3 Continued

\begin{tabular}{|c|c|c|c|}
\hline \multirow{2}{*}{ Title of journal } & \multicolumn{3}{|c|}{ Impact } \\
\hline & & factor & Impact \\
\hline Revue Etudes Comparées Est-Ouest & 2 & 0.1 & 0.2 \\
\hline Acta Oeconomica & 1 & 0.1 & 0.1 \\
\hline Journal of Economic Studies & 1 & 0.1 & 0.1 \\
\hline Review of Black Political Economy & 1 & 0.1 & 0.1 \\
\hline Singapore Economic Review & 1 & 0.0 & 0.0 \\
\hline
\end{tabular}

Source: Inforsk, Social Scisearch via Dialog.

Note: The table includes articles from the SSCI journal subject categories 'economics' and 'business finance'. The impact factor for a journal in for example 1986, is the number of citations in 1986 to articles published in the journal in 1984 and 1985 divided by the total number of articles published in the journal in 1984 and 1985. In the table a mean impact factor for the years $1977-88$ is presented. The impact factors were adapted from the Journal of Citation Reports. Impact factors are not available for every year for some of the journals.

Table 5.4 Percentage of articles in economic core journals 1973-89

\begin{tabular}{lccc}
\hline & $\begin{array}{c}\text { Articles in } \\
\text { economics }\end{array}$ & Thereof in core journals \\
Origin of author & & Number & $\%$ \\
\hline USA & 40,494 & 14,150 & 35 \\
United Kingdom & 7,167 & 2,460 & 34 \\
West Germany & 1,292 & 332 & 26 \\
France & 777 & 420 & 54 \\
Denmark, Norway, Finland & 720 & 251 & 35 \\
Sweden & 669 & 241 & 36 \\
& & & \\
Gothenburg & 63 & 18 & 29 \\
Lund & 103 & 31 & 30 \\
Stockholm & 423 & 182 & 43 \\
Umeå & 47 & 9 & 19 \\
Uppsala & 43 & 7 & 16 \\
\hline
\end{tabular}

Source: Garfield (1989), Inforsk: Social Scisearch via Dialog.

Note: Only genuine articles written in English are included. For the Swedish economists we may note that those in Stockholm, Lund and Gothenburg have a higher proportion of articles in core journals than Uppsala and Umeå. These differences may be attributed to specialization, since the latter departments are more specialized. As a result some of the relevant research findings from Uppsala and Umeå may be reported in specialized journals outside the core journal group. Due to city coauthorships the sum of articles over cities exceeds the total for Sweden. 
Table 5.5 Swedish citations in Handbooks in Economics

\begin{tabular}{|c|c|c|c|c|}
\hline \multirow[b]{2}{*}{ Handbook title } & \multirow[b]{2}{*}{ Year } & \multicolumn{3}{|c|}{$\begin{array}{c}\text { Number of } \\
\text { citations }\end{array}$} \\
\hline & & Total & $\begin{array}{l}\text { Swe } \\
\text { No. }\end{array}$ & $\begin{array}{l}i s h \\
\%\end{array}$ \\
\hline Regional and Urban Economics I-II & $1986-7$ & 2,906 & 72 & 2.5 \\
\hline International Economics I-II & $1984-5$ & 2,587 & 42 & 1.6 \\
\hline Mathematical Economics I-III & $1981-6$ & 3,261 & 48 & 1.5 \\
\hline Natural Resource and Energy I-II & 1985 & 1,262 & 14 & 1.1 \\
\hline Econometrics I-III & $1983-6$ & 4,163 & 40 & 1.0 \\
\hline Development Economics I-II & $1988-9$ & 4,140 & 32 & 0.8 \\
\hline Public Economics I-II & $1985-7$ & 2,252 & 16 & 0.7 \\
\hline Industrial Organisation I-II & 1989 & 3,604 & 13 & 0.4 \\
\hline Labor Economics I-II & 1986 & 2,329 & 8 & 0.3 \\
\hline Financial Economics & 1981 & 702 & 2 & 0.3 \\
\hline Total & & 27,206 & 287 & 1.1 \\
\hline
\end{tabular}

been registered. The identification of Swedish authors was based on an inspection of the lists and a reliance on some acquaintance with the names of well-known Swedish economists. Other names, which appeared to be of Swedish origin, were investigated by looking at the full names and personal information given in the cited article or monograph. The result of the investigation is summarized in table 5.5.

Table 5.5 indicates that Swedish researchers are most visible in regional and urban economics, international economics and mathematical economics. This result is to some extent a reflection of the fact that regional and international economics are fields of high Swedish research activity. The relative strength in mathematical economics can be attributed to a substantial extent to the statistician Herman Wold, who is referred to ten times in these volumes. He is also the most cited Swede in the Handbooks as a whole. An interesting observation is that the percentage of citations referring to Swedes (1.1 per cent) is almost the same as the Swedish share of all economic articles during the same period (cf. table 5.1).

The distribution of citations to individual authors is highly skewed. The 308 citations were made to 102 articles but 125 - i.e. 40 per cent of the Swedish references were to the seven most cited authors. An examination of these authors also reflects the interdisciplinary character of economics. The most cited author is the statistician Herman 


\section{Introduction and background studies}

Wold, to whom 30 references are made; another statistician, Karl Gustav Jöreskog with fifteen citations, also belongs to this group. Another author from outside the field of pure economics is Folke Snickars with thirteen citations, which illustrates the impact of Swedish research in regional economics.

The high frequency of citations to Herman Wold can be seen as a special trait of the handbook type of literature, since Wold can be regarded as one of the classical scholars not active in research but often discussed in surveys of historical developments. Other classical scholars among the seven most cited are Gunnar Myrdal and Bertil Ohlin, with fourteen and eleven citations respectively.

The only researcher still active in economics among the seven most cited is Lars E. O. Svensson, with nineteen citations. Although there are some active economists with up to eight citations ( $\mathrm{ke}$ E. Andersson, Börje Johansson and Karl-Göran Mäler), modern Swedish economics has not yet succeeded in reaching the international handbook stage to any appreciable extent.

\section{RELATIONS WITH THE INTELLECTUAL HERITAGE}

Thus far we have been using bibliometric indicators to describe the volume of publication activity by Swedish economists. In order to study the content of economic research in Sweden, we can turn to the citations made in journal articles. The citations could be regarded as links with the knowledge base of the research, and as a reflection of its content.

The social sciences are often considered to be more local and more nationally oriented than the natural sciences. A great deal of social science research has been initiated and financed by government agencies in various sectors. Criticism of this sectorial research has sometimes suggested that the research has limited relevance to basic science. The natural sciences are seen as being much more universal and less subject to national bias.

One way of testing the universality of Swedish economics is to compare the citations to some of the founding fathers of this field in the different countries. One starting-point has been to study the way in which countries allocate citations to the Nobel laureates in economics. Table 5.6 shows a very strong resemblance between the Swedish and the international citation profiles.

The only deviations, not surprisingly, refer to Gunnar Myrdal and Bertil Ohlin. The correlation between the two distributions is as high as 0.92 . This is a clear indication of the universal nature of Swedish 
Swedish economics on the international scene

Table 5.6 Number of articles 1973-89 citing Nobel laureates

\begin{tabular}{|c|c|c|c|c|c|c|}
\hline \multirow[b]{2}{*}{ Laureate name } & \multirow[t]{2}{*}{ Year } & \multicolumn{2}{|c|}{ Number } & \multicolumn{2}{|c|}{ Percentage } & \multirow[t]{2}{*}{$R C R$} \\
\hline & & World & Sweden & World & Sweden & \\
\hline Friedman, $\mathrm{M}$. & 1976 & 8,807 & 95 & 12.56 & 13.97 & 1.11 \\
\hline Arrow, $\mathbf{K}$. & 1972 & 7,628 & 67 & 10.88 & 9.85 & 0.91 \\
\hline Simon, $\mathrm{H}$. & 1978 & 7,048 & 74 & 10.05 & 10.88 & 1.08 \\
\hline Samuelson, $P$. & 1970 & 6,460 & 55 & 9.21 & 8.09 & 0.88 \\
\hline Stigler, G. & 1982 & 4,746 & 21 & 6.77 & 3.09 & 0.46 \\
\hline Tobin, J. & 1981 & 3,568 & 41 & 5.09 & 6.03 & 1.18 \\
\hline Hicks, J. & 1972 & 3,462 & 40 & 4.94 & 5.88 & 1.19 \\
\hline Buchanan, J. & 1986 & 3,366 & 28 & 4.80 & 4.12 & 0.86 \\
\hline Myrdal, G. & 1974 & 2,818 & 55 & 4.02 & 8.09 & 2.01 \\
\hline Modigliani, F. & 1985 & 2,342 & 15 & 3.34 & 2.21 & 0.66 \\
\hline Solow, R. & 1987 & 2,223 & 30 & 3.17 & 4.41 & 1.39 \\
\hline Schultz, T. & 1979 & 2,062 & 15 & 2.94 & 2.21 & 0.75 \\
\hline Kuznets, S. & 1971 & 1,872 & 11 & 2.67 & 1.62 & 0.61 \\
\hline Lewis, A. & 1979 & 1,774 & 20 & 2.53 . & 2.94 & 1.16 \\
\hline Klein, L. & 1980 & 1,694 & 13 & 2.42 & 1.91 & 0.79 \\
\hline Debreu, G. & 1983 & 1,691 & 9 & 2.41 & 1.32 & 0.55 \\
\hline Leontief, W. & 1973 & 1,610 & 17 & 2.30 & 2.50 & 1.09 \\
\hline Tinbergen, $\mathbf{J}$. & 1969 & 1,251 & 6 & 1.78 & 0.88 & 0.49 \\
\hline Meade, $\mathbf{J}$. & 1977 & 1,220 & 7 & 1.74 & 1.03 & 0.59 \\
\hline Stone, R. & 1984 & 1,199 & 6 & 1.71 & 0.88 & 0.51 \\
\hline Koopmans, T. & 1975 & 1,110 & 14 & 1.58 & 2.06 & 1.30 \\
\hline Frisch, R. & 1969 & 1,072 & 20 & 1.53 & 2.94 & 1.92 \\
\hline Allais, $\mathrm{M}$. & 1988 & 376 & 1 & 0.54 & 0.15 & 0.28 \\
\hline Ohlin, B. & 1977 & 300 & 16 & 0.43 & 2.35 & 5.47 \\
\hline von Hayek, F. A. & 1974 & 239 & 4 & 0.34 & 0.59 & 1.74 \\
\hline Kantorovich, L. & 1975 & 191 & 0 & 0.27 & 0.00 & 0.00 \\
\hline Total & & 70,129 & 680 & 100.00 & 100.00 & 1.00 \\
\hline
\end{tabular}

Source: Inforsk, Social Scisearch via Dialog.

Note: RCR, the relative citation rate, is calculated by dividing the percentage of the Swedish citations referring to a Laureate with the corresponding percentage for the world as a whole.

economic research, and one might wonder whether it is relevant to talk about a national research system in any other than institutional terms.

Citation frequencies, it should perhaps be added, show that very few of the Swedish professors reach citation scores on a level with any Nobel laureate. Among Swedish economists currently active, only Assar Lindbeck and Staffan Burenstam-Linder have received more than 300 citations. We can compare this with the Swedish professors 


\section{Introduction and background studies}

Table 5.7 Citations 1973-89 to major schools of thought in macroeconomics. Relative Citation Ratio (RCR)

\begin{tabular}{lrrrrr}
\hline School & \multicolumn{5}{c}{$\begin{array}{c}\text { West } \\
\text { USA }\end{array}$} \\
\hline England & Germany & France & Sweden \\
\hline Neo-Ricardians & 0.49 & 1.67 & 2.50 & 2.61 & 0.46 \\
Monetarists & 1.02 & 0.56 & 2.21 & 1.55 & 1.69 \\
Post Keynesians & 1.01 & 0.76 & 0.90 & 0.93 & 0.30 \\
(Residuum) & 1.04 & 0.79 & 1.17 & 0.85 & 0.80 \\
Econometric approach & 1.03 & 0.88 & 0.89 & 0.75 & 1.32 \\
Disequilibrium theory & 0.81 & 1.00 & 1.71 & 2.66 & 2.48 \\
Classical economists & 0.84 & 1.55 & 1.05 & 1.18 & 0.59 \\
Implicit contracts & 1.13 & 0.80 & 0.91 & 1.14 & 0.58 \\
Keynes' contemporaries & 0.86 & 1.31 & 1.00 & 1.00 & 0.67 \\
Empirical approaches & 1.15 & 0.79 & 0.69 & 0.85 & 0.80 \\
Neoclassical synthesis & 0.91 & 1.08 & 1.15 & 1.03 & 1.09 \\
New classical economists & 1.07 & 0.93 & 0.86 & 0.94 & 1.17 \\
& & & & & \\
Number of citations & 47,373 & 7,151 & 1,185 & 1,771 & 725 \\
\hline
\end{tabular}

Source: Inforsk, Social Scisearch via Dialog, and McCain (1986).

Note: $\mathrm{RCR}$, the relative citation rate, is calculated by dividing the percentage of a country's citations referring to a school with the corresponding percentage for the world as a whole.

of sociology, of whom three or four also reach similar numbers of citations (Allardt et al. 1988).

Another technique which can be used to study the relation with the intellectual heritage is co-citation analysis. This technique has been employed by McCain (1986) in a study based on a selection of macroeconomists, most of them American. This showed, among other things, a cluster structure consisting of eleven groups of highly co-cited authors. In table 5.7 we can see that Swedish articles, as well as French and West German, cite Disequilibrium Theorists and Monetarists noticeably more often than the world average. Econometricians are more cited in the Swedish articles. In Great Britain Keynes's Contemporaries, the Classical Economists and Neo-Ricardians, are somewhat more frequently cited. Because of its large share of the world article production, the United States comes close to the world average, except for the undercitation of the Neo-Ricardians.

\section{RESEARCH PROFILES}

Research activity could be expected to vary between institutions, due to local traditions and the interests of researchers. There are two main 
ways of arriving at a description of research profiles. One is to use an established indexing system, such as the classifications made by the Journal of Economic Literature (JEL). The other is to use the citations in the articles and to cluster the articles on a basis of the number of shared references (bibliographic coupling).

\section{Classification by index terms}

In a first study we adopted the classifications made by the JEL for each article retrieved from the economic journals in the Social Scisearch. Table 5.8 shows the relative tendency to publish in a subject field for each major university city. The subject fields are ranked according to the number of articles classified within each category. Besides general economic theory, which could be anything that could not be classified elsewhere, there are a large number of articles on labour market and public policy, as well as on fiscal theory and public finance. International finance and trade theory are also important fields of study but of less volume.

The first impression is that the distribution of articles by subject is quite similar for the five cities. If we compare the number of articles for each pair of cities we find the Pearson correlation coefficient varying between 0.75 and 0.91 . Table 5.8 shows Stockholm clearly dominating the fields of trade relations, international trade theory, international finance, international investment and foreign aid. In Uppsala welfare, health and education is a field of high activity compared to the other cities. In Umeå labour markets and public policy, domestic monetary and financial theory, together with the economics of technological change are of relative importance. Lund has a comparatively large number of articles in the fields of fiscal theory and planning and public finance, as well as in economic growth, development and planning. In Gothenburg most of the articles are classified as general economic theory.

Stockholm is by far the most active city in terms of publications in economics, with more than 60 per cent of the Swedish articles. This can be explained by the presence of several research institutes, as well as the university department of economics. In table 5.9 the number of articles emanating from Stockholm institutes are shown by subject field. The Institute of International Economic Studies is responsible for 63 per cent of all authorships from the four institutes listed in the table. This means that this institute dominates almost every subfield in the classification, but of course it has a particularly large number of articles on international economics. 


\section{Introduction and background studies}

Table 5.8 Subject classification of Swedish SSCI-articles 1973-89 in economics by city

\begin{tabular}{|c|c|c|c|c|c|c|}
\hline Subject & $\begin{array}{l}\text { Stock- } \\
\text { holm }\end{array}$ & $\begin{array}{l}\text { Upp- } \\
\text { sala }\end{array}$ & Umeå & Lund & $\begin{array}{l}\text { Gothen- } \\
\text { burg }\end{array}$ & Total \\
\hline $\begin{array}{l}\text { General economic theory } \\
\text { Labour markets; }\end{array}$ & 91 & 14 & 14 & 39 & 13 & 171 \\
\hline $\begin{array}{l}\text { Public policy } \\
\text { Fiscal theory and nolicy. }\end{array}$ & 69 & 7 & 11 & 10 & 5 & 102 \\
\hline $\begin{array}{l}\text { Fiscal theory and policy; } \\
\text { Public finance } \\
\text { Economic fluctuations: }\end{array}$ & 59 & 5 & 4 & 15 & 2 & 85 \\
\hline $\begin{array}{l}\text { Economic fluctuations; } \\
\text { Forecasting } \\
\text { Trade relations }\end{array}$ & $\begin{array}{l}43 \\
39\end{array}$ & $\begin{array}{l}6 \\
4\end{array}$ & $\begin{array}{l}3 \\
2\end{array}$ & $\begin{array}{l}2 \\
2\end{array}$ & 1 & $\begin{array}{l}55 \\
48\end{array}$ \\
\hline $\begin{array}{l}\text { Trade relations } \\
\text { International trade } \\
\text { theory }\end{array}$ & 41 & 2 & 3 & 1 & 0 & 47 \\
\hline $\begin{array}{l}\text { International finance } \\
\text { Natural resources }\end{array}$ & $\begin{array}{l}39 \\
20\end{array}$ & $\begin{array}{l}2 \\
5\end{array}$ & $\begin{array}{l}2 \\
3\end{array}$ & $\begin{array}{l}0 \\
1\end{array}$ & $\begin{array}{l}0 \\
3\end{array}$ & $\begin{array}{l}43 \\
32\end{array}$ \\
\hline $\begin{array}{l}\text { Domestic monetary } \\
\text { and financial theory }\end{array}$ & 22 & 3 & 6 & 0 & 0 & 31 \\
\hline $\begin{array}{l}\text { Economic growth; } \\
\text { Development and } \\
\text { planning }\end{array}$ & 17 & 4 & 2 & 8 & 0 & 31 \\
\hline $\begin{array}{l}\text { Industrial organization } \\
\text { and public policy } \\
\text { Industry studies }\end{array}$ & $\begin{array}{l}17 \\
15\end{array}$ & $\begin{array}{l}2 \\
4\end{array}$ & $\begin{array}{l}5 \\
2\end{array}$ & $\begin{array}{l}4 \\
6\end{array}$ & $\begin{array}{l}2 \\
3\end{array}$ & $\begin{array}{l}30 \\
30\end{array}$ \\
\hline $\begin{array}{l}\text { History of economic } \\
\text { thought }\end{array}$ & 10 & 2 & 5 & 2 & 3 & 22 \\
\hline $\begin{array}{l}\text { International investment } \\
\text { and foreign aid }\end{array}$ & 18 & 1 & 3 & 0 & 0 & 22 \\
\hline $\begin{array}{l}\text { Welfare; Health; } \\
\text { Education }\end{array}$ & 11 & 7 & 3 & 0 & 0 & 21 \\
\hline Regional economics & 6 & 4 & 2 & 4 & 1 & 17 \\
\hline $\begin{array}{l}\text { Econometric, statistical } \\
\text { and mathematical } \\
\text { methods }\end{array}$ & 8 & 3 & 3 & 3 & 0 & 17 \\
\hline Trade unions; & & & & & & \\
\hline Collective bargaining & 15 & 2 & 0 & 0 & 0 & 17 \\
\hline Urban economics & 13 & 2 & 1 & 0 & 0 & 16 \\
\hline $\begin{array}{l}\text { Economics of } \\
\text { technological change }\end{array}$ & 6 & 3 & 6 & 1 & 0 & 16 \\
\hline $\begin{array}{l}\text { Economic and social } \\
\text { statistical data } \\
\text { and analysis }\end{array}$ & & & & & & \\
\hline $\begin{array}{l}\text { and analysis } \\
\text { Country studies }\end{array}$ & $\begin{array}{l}12 \\
10\end{array}$ & 4 & 1 & 0 & $\begin{array}{l}0 \\
0\end{array}$ & $\begin{array}{l}10 \\
15\end{array}$ \\
\hline Administration & 8 & 4 & 2 & 0 & 0 & 14 \\
\hline Consumer economics & 7 & 3 & 3 & 1 & 0 & 14 \\
\hline $\begin{array}{l}\text { Manpower training } \\
\text { and allocation }\end{array}$ & 9 & 1 & 0 & 0 & 0 & 10 \\
\hline
\end{tabular}


Table 5.8 Continued

\begin{tabular}{|c|c|c|c|c|c|c|}
\hline Subject & $\begin{array}{l}\text { Stock- } \\
\text { holm }\end{array}$ & $\begin{array}{l}\text { Upp- } \\
\text { sala }\end{array}$ & Umeå & Lund & $\begin{array}{l}\text { Gothen- } \\
\text { burg }\end{array}$ & Total \\
\hline Economic history & 7 & 2 & 1 & 0 & 0 & 10 \\
\hline \multicolumn{7}{|l|}{$\begin{array}{l}\text { Administration; } \\
\text { Business Finance; }\end{array}$} \\
\hline Marketing & 5 & 3 & 0 & 0 & 0 & 8 \\
\hline Economic systems & 6 & 1 & 0 & 0 & 0 & 7 \\
\hline General economics & 5 & 1 & 0 & 0 & 0 & 6 \\
\hline \multicolumn{7}{|l|}{$\begin{array}{l}\text { Human capital; } \\
\text { Value of human }\end{array}$} \\
\hline life & 4 & 0 & 0 & 0 & 0 & 4 \\
\hline Agriculture & 3 & 1 & 0 & 0 & 0 & 4 \\
\hline Demographic economics & 1 & 1 & 0 & 0 & 0 & 2 \\
\hline \multicolumn{7}{|l|}{ International economics; } \\
\hline General & 2 & 0 & 0 & 0 & 0 & 2 \\
\hline Economic geography & 1 & 1 & 0 & 0 & 0 & 2 \\
\hline Economic capacity & 2 & 0 & 0 & 0 & 0 & 2 \\
\hline \multicolumn{7}{|l|}{ Business finance } \\
\hline and investment & 7 & 0 & 0 & 0 & 0 & 7 \\
\hline Number of classifications & 648 & 107 & 88 & 99 & 34 & 976 \\
\hline
\end{tabular}

Source: Inforsk, Social Scisearch via Dialog and the Journal of Economic Literature. The classification is based on the subject codes according to the Journal of Economic Literature. An article could be indexed by up to four subject codes.

The Swedish Institute for Social Research publishes a lot of work on labour market and public policy, and general economic theory. The Stockholm School of Economics has a broad profile with some emphasis on fiscal theory and economic fluctuations, forecasting, etc, but it must be stressed that business administration which is an active field at this particular school was not included in the sample of articles from Social Scisearch. The department of economics at Stockholm University also has a broad scatter of articles across subject fields, but many of the articles are classified as general economic theory.

We can get yet another indication of profile by comparing the classification made by the Journal of Economic Literature (JEL) of the Swedish SSCI-articles with the classification made of all articles in $\mathrm{JEL}^{2}$. From table 5.10 we can conclude that general economics, international economics and manpower and labour research have a strong position in the Swedish profile. It should be stressed that the JEL world profile includes articles from journals in the fields of 


\section{Introduction and background studies}

Table 5.9 Subject classification of Stockholm articles 1973-89 in economics by major institution

\begin{tabular}{|c|c|c|c|c|c|c|}
\hline Subject & $S U$ & $H H S$ & IIES & SOFI & Other & Total \\
\hline General economic theory & 15 & 10 & 44 & 15 & 7 & 91 \\
\hline \multicolumn{7}{|l|}{ Labour markets; } \\
\hline Public policy & 4 & 6 & 32 & 17 & 10 & 69 \\
\hline \multicolumn{7}{|l|}{ Fiscal theory and policy; } \\
\hline Public finance & 7 & 8 & 28 & 9 & 7 & 59 \\
\hline \multicolumn{7}{|l|}{ Economic fluctuations; } \\
\hline Forecasting & 4 & 8 & 22 & 7 & 2 & 43 \\
\hline Trade relations & 2 & 2 & 27 & 5 & 3 & 39 \\
\hline \multicolumn{7}{|l|}{ International trade } \\
\hline theory & 0 & 2 & 37 & 2 & 0 & 41 \\
\hline International finance & 1 & 0 & 38 & 0 & 0 & 39 \\
\hline Natural resources & 4 & 4 & 10 & 0 & 2 & 20 \\
\hline \multicolumn{7}{|l|}{ Domestic monetary } \\
\hline and financial theory & 2 & 6 & 13 & 0 & 1 & 22 \\
\hline \multicolumn{7}{|l|}{ Economic growth; } \\
\hline $\begin{array}{l}\text { Development and } \\
\text { planning }\end{array}$ & 1 & 2 & 13 & 1 & 0 & 17 \\
\hline \multicolumn{7}{|l|}{ Industrial organization } \\
\hline and public policy & 5 & 4 & 6 & 1 & 1 & 17 \\
\hline Industry studies & 2 & 0 & 7 & 3 & 3 & 15 \\
\hline \multicolumn{7}{|l|}{ History of economic } \\
\hline thought & 1 & 5 & 3 & 0 & 6 & 10 \\
\hline \multicolumn{7}{|l|}{ International investment } \\
\hline Welfare; Health; Education & 4 & 1 & 1 & 2 & 3 & 11 \\
\hline Regional economics & 0 & 0 & 0 & 0 & 6 & 6 \\
\hline \multicolumn{7}{|l|}{$\begin{array}{l}\text { Econometric, statistical } \\
\text { and mathematical }\end{array}$} \\
\hline methods & 0 & 0 & 0 & 1 & 7 & 8 \\
\hline \multicolumn{7}{|l|}{ Trade unions; } \\
\hline Collective bargaining & 1 & 0 & 9 & 2 & 3 & 15 \\
\hline Urban economics & 4 & 2 & 3 & 2 & 2 & 13 \\
\hline \multicolumn{7}{|l|}{ Economics of } \\
\hline \multicolumn{7}{|l|}{$\begin{array}{l}\text { Economic and social } \\
\text { statistical data }\end{array}$} \\
\hline and analysis & 1 & 0 & 5 & 2 & 4 & 12 \\
\hline Country studies & 0 & 1 & 8 & 0 & 1 & 10 \\
\hline Administration & 0 & 0 & 1 & 1 & 6 & 8 \\
\hline Consumer economics & 1 & 1 & 3 & 0 & 2 & 7 \\
\hline \multicolumn{7}{|l|}{ Manpower training } \\
\hline and allocation & 0 & 0 & 1 & 3 & 5 & 9 \\
\hline Economic history & 0 & 1 & 3 & 2 & 1 & 7 \\
\hline
\end{tabular}


Table 5.9 Continued

\begin{tabular}{|c|c|c|c|c|c|c|}
\hline Subject & $S U$ & $H H S$ & $I I E S$ & SOFI & Other & Total \\
\hline \multicolumn{7}{|l|}{ Administration; } \\
\hline \multicolumn{7}{|l|}{ Business finance; } \\
\hline Marketing & 0 & 0 & 0 & 0 & 5 & 5 \\
\hline Economic systems & 0 & 1 & 3 & 0 & 2 & 6 \\
\hline General economics & 1 & 0 & 3 & 0 & 1 & 5 \\
\hline \multicolumn{7}{|l|}{ Human capital; } \\
\hline \multicolumn{7}{|l|}{ Value of human } \\
\hline life & 1 & 0 & 1 & 0 & 2 & 4 \\
\hline Agriculture & 0 & 0 & 0 & 0 & 3 & 3 \\
\hline Demographic economics & 0 & 0 & 0 & 0 & 1 & 1 \\
\hline \multicolumn{7}{|l|}{ International economics; } \\
\hline General & 0 & 1 & 0 & 0 & 1 & 2 \\
\hline Economic geography & 0 & 0 & 0 & 0 & 1 & 1 \\
\hline Economic capacity & 0 & 1 & 0 & 1 & 0 & 2 \\
\hline \multicolumn{7}{|l|}{ Business finance } \\
\hline and investment & 2 & 0 & 1 & 4 & 0 & 7 \\
\hline Number of classifications & 64 & 67 & 340 & 82 & 100 & 648 \\
\hline
\end{tabular}

Source: Inforsk, Social Scisearch via Dialog and JEL.

business administration and regional economics, while our sample of Swedish articles from the Social Scisearch does not. If these journals had been included in our sample, the field of welfare and regional economics at least would have been better represented.

In an evaluation context it is not altogether obvious what these research profiles really imply. To some extent the data just seem to reflect the research orientations of various units, which are already known to many experts of the field. However, because of differences in publication patterns in various fields of economics, the publication counts may not in fact reflect research activity. Consequently, there may be fields with a large volume of publications which are not very visible in the international journal market.

\section{Classification by bibliographic coupling}

One disadvantage of using the classification codes of the JEL is that they are not sensitive enough to the endogenous dynamics of research; articles are forced into a static scheme of subfields. To be able to make an analysis that is not dependent upon pre-established index systems, we applied a special computer software developed at Inforsk (Persson, Stern and Holmberg 1990). We first downloaded all Swedish articles 


\section{Introduction and background studies}

Table 5.10 Swedish and world articles 1973-89 in economics classified by major field

\begin{tabular}{lrrrr}
\hline & \multicolumn{2}{c}{ Number } & \multicolumn{2}{c}{ Percentage } \\
& Sweden & World & Sweden & World \\
\hline General economics & 279 & 43,316 & 24.01 & 17.76 \\
$\begin{array}{l}\text { Economic growth } \\
\text { Quantitative economics }\end{array}$ & 123 & 23,415 & 10.59 & 9.60 \\
$\begin{array}{l}\text { Domestic monetary and } \\
\text { fiscal }\end{array}$ & 142 & 15,285 & 3.36 & 6.27 \\
$\begin{array}{l}\text { International economics } \\
\begin{array}{l}\text { Administration and } \\
\text { business finance }\end{array}\end{array}$ & 191 & 33,098 & 12.22 & 13.57 \\
$\begin{array}{l}\text { Industrial organization } \\
\text { and technological }\end{array}$ & 29 & 13,783 & 2.50 & 5.80 \\
$\begin{array}{c}\text { change } \\
\text { Agriculture and } \\
\text { natural resources }\end{array}$ & 91 & 24,217 & 7.83 & 9.93 \\
$\begin{array}{l}\text { Manpower, labour, } \\
\text { and population }\end{array}$ & 147 & 24,828 & 12.65 & 10.18 \\
$\begin{array}{l}\text { Welfare programmes and } \\
\text { regional economics }\end{array}$ & 72 & 25,398 & 6.20 & 10.41 \\
$\begin{array}{l}\text { Number of classifications } \\
\quad 1,162\end{array}$ & 243,946 & 100.00 & 100.00 \\
\hline
\end{tabular}

Source: Inforsk, Social Scisearch via Dialog and JEL.

in economics and business finance from the Social Scisearch, 685 genuine articles in all. The computer program then calculated the number of shared cited authors between each pair of articles. This measure of bibliographic coupling was then used for a single-link clustering routine, which grouped the Swedish articles sharing a minimum of three cited authors. At this level of similarity twenty-six clusters emerged, incorporating only 35 per cent of all articles (Stern 1990).

The remaining 65 per cent of the non-clustered articles are most likely related to international research activities. This could be another good indication of a universal orientation and of a high degree of specialization in Swedish economics. Our interpretation of these findings is that it is difficult to speak of a specific school of Swedish economics during the last two decades. Instead, Swedish research is very much in line and integrated with international economic research. This also implies that Swedish research should be evaluated in an international context. It does not seem very appropriate to limit an evaluation study to a comparison between Swedish researchers. 
The twenty-six clusters formed should be regarded as reflecting subfields of high Swedish activity, which means that many Swedes are active within these fields. Only four of these clusters had more than ten articles. These clusters were classified as labour market research (twenty-three articles), taxation and welfare (twenty-one articles), production functions (eighteen articles) and international economics and trade (fourteen articles). The remaining clusters correspond to relatively small research specialties of greater specificity, which the JEL-based classification is not able to identify. However, the largest clusters correspond to the most active fields which we found by using the JEL classification (table 5.10).

\section{CONCLUSIONS}

For some years the internationalization of research has been an important objective of Swedish science policy. The publication of research results in international journals is one of the ways of fulfilling this goal. From our study of the publication activities of Swedish economists we can conclude that their share of world output has increased since the 1970s, and the level of article production is now the same as in the natural sciences. However, there are a great many researchers who have published less than two papers in international journals over a fifteen-year period. This shows that international publication has not been given very high priority by many scholars. On the other hand, it should not be too demanding a task to increase the Swedish output of scientific articles. The journal selection behaviour of Swedish economists appears to strike a reasonable balance between much cited core journals and specialized periodicals. The Scandinavian Journal of Economics belongs to the upper half of the journal citation ranking lists. It seems justifiable to use this journal for international publication, and to market the journal to attract foreign authors and subscribers.

Looking at the regional variations in publication activity we find that Stockholm has published more than 60 per cent of all Swedish articles. The IIES accounts for one-third of the Swedish output and two-thirds of the Stockholm article production. Consequently, in terms of research specialization, Stockholm dominates the field of international economics. General economic theory, labour market and public policy issues are important fields at all universities, and the correlation between their research profiles is fairly high.

According to the citation patterns for articles, Swedish economists use the same intellectual base as researchers in the rest of the world. In 


\section{Introduction and background studies}

this respect the internationalization of Swedish research in this discipline has already come a long way. On the other hand it is evident that only a few of the currently active Swedish economists play a significant role in terms of international publication and impact.

Our attempt to describe the subfield structure of economics has some obvious limitations. The use of a pre-established classification scheme has generated some fairly unsurprising results. Bibliographic coupling is an interesting alternative but needs to be further improved. First of all, it would be desirable to study the citation networks on a global level to be able to locate Swedish research in the international contexts. It is also of prime importance to confront the bibliometric models with the various groups of scientists concerned. 


\section{Part II \\ The views of the international evaluation committee}





\title{
6 Swedish economics in the 1980s
}

\author{
Avinash K. Dixit, Seppo Honkapohja and \\ Robert M. Solow
}

\section{SWEDISH ECONOMICS AFTER THE STOCKHOLM SCHOOL}

The two great bursts of creativity in Swedish economics - CasselDavidson-Heckscher-Wicksell around the turn of the century and the Stockholm School in the 1920s and 1930s - are described briefly in Chapter 2 above. Those episodes are without parallel in the modern history of economics. No other small country has produced anything genuinely comparable. It is true that Norway and the Netherlands have originated distinctive schools of thought. But each of those has been, to a much greater extent, the creation of a single great figure, Frisch in one case and Tinbergen in the other. The first and second Swedish Schools did not consist primarily of Wicksell and followers or Lindahl and followers. It would be a worthwhile study in the history of economics - or in intellectual history generally - to try to understand why it happened in Sweden, not once but twice.

The memory of those two great episodes has probably placed an unfair burden on Swedish economists today. Why should there not be a third Swedish School of comparable significance? We suggest that such developments have become less and less likely, and are now perhaps no longer possible. As was indicated in Chapter 5, over the past three or four decades the literature of analytical economics has become almost completely homogeneous worldwide. Mainstream economists in all countries now contribute to a single international literature as part of a single intellectual community. The emergence of English as a common language for economists and the development of communications technology - the fax being only the latest example have unified the community of academic economists and eliminated the lag in the transmission of ideas. The mobility of individual researchers, enhanced by the possibility of graduate study and sabbaticals abroad and by the proliferation of international conferences, has a 
further unifying effect. One can easily imagine a new idea or technique arising anywhere in the world of mainstream economics, and being pursued at first by its originator and his or her graduate students, but one cannot easily imagine a distinctively national school arising within the mainstream. Good ideas circulate much too rapidly.

Over the past four decades Swedish economics has become successively more closely integrated into the broad international community of mainstream economics. In many areas of economics and in the most advanced departments and institutes, this process is now essentially complete. Of course the Swedish (or the Nordic) economy has its own special characteristics and its own particular problems. It will therefore always be appropriate for some academic research in Sweden (and a fortiori much non-academic research) to be devoted to problems of exclusively or primarily Swedish interest. But behind even this kind of research there should be people who are integrated into the international profession, not just some parochial subset. Even local problems can be generalized and internationalized. It is a fair guess that most of the writing on 'the Dutch disease' has been produced outside the Netherlands. Swedish economists, even when their work is inspired by Swedish problems, should try to generalize their results, if only to make their work more acceptable to the international journals in which they wish to publish and to communicate with their peers elsewhere.

The following brief surveys are not intended as evaluations of Swedish research in particular subfields of economics. Nor are they intended to be complete summaries of what has been done in Swedish universities and research institutes. They are intended merely to give a flavour of the coverage of the field of economics by Swedish scholars, and to illustrate the progress of integration with the international mainstream. Since Swedish economics has been particularly extensive in certain specialized fields (cf. Chapter 5 above), we first discuss recent Swedish work in these fields of economics on pages 130-40. Research outside these fields is then considered under the general headings of macro and monetary economics on pages $140-2$, and microeconomics on pages 142-3. It should also be noted that the list of selected references is meant to be illustrative, focusing mainly on entries that should be accessible to the international economics profession.

\section{LABOUR ECONOMICS}

The Swedish labour market has some distinctive characteristics that, taken together, differentiate it from the labour markets of other 
advanced industrial economies. A very large proportion of Swedish workers belong to trade unions. Collective bargaining is highly centralized. (These two characteristics give rise to 'wage drift'.) During much of the recent period collective bargaining in Sweden has been influenced by the 'solidarity wage policy' that has committed the union side to the narrowing of wage differentials. Finally, the Swedish labour market exists in an environment in which full employment is given very high priority as a goal of government policy, and in which labour market policy is 'active' and very detailed.

These distinguishing characteristics have been reflected in Swedish contributions to the study of wage determination and employment. The phenomenon of wage drift has been a subject of study ever since the first Phillips-curve-related papers were published by Jacobsson and Lindbeck (1969). It is not far-fetched to connect the recent 'insider-outsider' models of Lindbeck and Snower (1988) with the high trade-union density (though this is perhaps in some conflict with the notion of the solidarity wage policy). Nevertheless, as we shall see, Swedish research in this area has followed the broad lines of international mainstream literature, and has made notable contributions to it.

Labour economics has flourished in all Swedish university departments, although more actively in some than in others. In addition one must pay particular attention to the Swedish Institute for Social Research (SOFI) and the Institute for International Economic Studies (IIES) at Stockholm University, and to the Trade Union Institute for Economic Research (FIEF), established in 1985 in Stockholm by the Swedish Confederation of Labour (LO). This point can be illustrated by reference to the work of two research institutes specializing in labour economics: the Swedish Institute for Social Research (formerly the Institute for Labour Market Studies) and FIEF.

The Swedish Institute for Social Research is divided between economics and sociology (currently two of the five professors attached to the Institute are economists and three are sociologists). We refer only to such research as is identifiably economics. If we look at the reprints of published articles listed by the Institute, we find that eighteen of the thirty most recent reprints were published in English compared with only three of the thirty immediately preceding reprints. (The relevant periods are approximately 1981-6 and 1986-9.) At least two of the ten Ph.D. theses currently in progress are on subjects of general interest in the international literature of labour economics. That could be said of only one of the six theses completed since 1983; and the author of that one is currently working on the 'Beveridge 


\section{Views of the international evaluation committee}

curve', another topic that is now pursued everywhere in Europe and North America.

The Economic Research Reports of FIEF include papers by Swedish economists and by visiting foreigners, and several more written jointly by Swedes and others. Although the topics covered are very clearly within the intended scope of the Institute, many would be of interest to the broad community of economists. Indeed many have been published in international journals (Public Finance, Journal of Public Economics, European Economic Review, Weltwirtschaftliches Archiv) in English. Several have appeared in British journals, and still others in the United States. The only book that has so far appeared from FIEF (Holmlund, Löfgren and Engström 1989) contains two essays, one on the effects of trade unionism on employment and one on the duration of unemployment. The first is by Bertil Holmlund of Uppsala and the second by Karl-Gustaf Löfgren and Lars Engström of Umeå. Both papers would be at home in any international gathering of labour economists, although they are based on Swedish data and have relevance to the Swedish labour market.

At IIES work on the macroeconomics of the labour market started with Lars Calmfors's doctoral thesis in 1978: Prices, Wages and Employment in the Open Economy. Calmfors's work was already in international circulation, i.e. in his contribution to a Brookings volume in 1977 (Calmfors 1977). In recent years Calmfors has headed a project on Wage Formation in the Nordic Countries. Lindbeck, in collaboration with Dennis Snower, has developed the 'insideroutsider' model of wage formation and written on it extensively (e.g. Lindbeck and Snower 1988). Others at IIES, notably Nils Gottfries and Henrik Horn, have contributed to modern non-Walrasian theories of wage determination (Gottfries and Horn 1987).

The study directed by Calmfors (1990) provides a classic example of the internationalization process. It was commissioned by the Nordic Economic Research Council and it includes four detailed country studies, each written by a team from the country concerned. The second part of the volume reports the results of case studies and a comparative analysis of centralized and decentralized wage-setting. These five papers include two by English economists and one by an American. Calmfors himself contributes a long summary and an introduction. The book is published jointly by the Centre for Business and Policy Studies (SNS) and the Oxford University Press. It is stateof-the-art applied economics and will very likely attract international attention.

At the universities the distribution of teaching and research in 
labour economics is very uneven. One of the disadvantages of the small scale is that any given university may have no one on the faculty with a research interest in labour economics. Or if there is someone, the interest may only be practised part-time and will almost certainly be specialized within the field.

The broadest coverage of labour economics is probably at Uppsala since the arrival of Bertil Holmlund as professor there. Together with Per-Anders Edin, Anders Forslund, Johnny Zetterberg and several visitors from abroad, he has produced a body of work both on specifically Swedish problems and on issues that fall squarely into the domain of the international literature on wages and employment (e.g. Edin and Zetterberg 1989, Holmlund and Zetterberg 1989). In fact both categories are combined in Holmlund's long contribution ('Wages and Employment in Unionized Economies: Theory and Evidence') to the FIEF volume on Trade Unions, Employment and Unemployment Duration (Holmlund, Löfgren and Engström 1989).

At Gothenburg, the MICROHUS simulation model has, of course, a labour-supply block and pays some attention to wages. Anders Klevmarken and his associates have written on this topic. Gothenburg is also the source of theses and published papers on the labour market in developing countries. At Lund, on the other hand, interest in labour economics appears mainly in the work of Inga Persson (e.g. Björklund and Persson-Tanimura 1983) and Christina Jonung (1984) on the role of women in the labour market and related questions.

At Umeå the source of work on labour economics is Karl-Gustav Löfgren, who provided the second half of the FIEF volume referred to earlier, surveying theory and evidence on the duration of spells of unemployment.

\section{NATURAL RESOURCES}

As the importance of agriculture has diminished in the advanced economies, the study of the economics of renewable and nonrenewable natural resources has become a minority taste. This may be in the process of changing, because of the worldwide upsurge of interest in environmental questions. There is a natural affinity between environmental economics and resource economics, probably because some of the biggest environmental problems amount to the degradation of a public natural resource such as land, water or ambient air. If environmental and resource economics are enjoying an upswing, there will be an opportunity - very important in an environmentally aware society like Sweden - to organize its growth efficiently. The current 


\section{Views of the international evaluation committee}

state of resource economics illustrates very well the problems of a small field in a small country.

The main centre of work in this field is the Stockholm School of Economics (HHS) under Karl-Göran Mäler, who has published in the area since the early 1970s (see e.g. Mäler 1974). About ten people are involved. Currently there is work on sustainable development in LDCs, and the impact of taxes on resources and environment in developing countries. Mäler has also developed a model of strategic interaction with respect to trans-border aspects of acid rain (Mäler 1990). These are examples of problems of great interest both inside and outside Sweden; the audience for this work is international. Work is also in progress on resource valuation, energy economics and other related topics.

The second centre of work in this field is Umeå, where Karl-Gustaf Löfgren and to a certain extent Tönu Puu are conducting research. The graduate student body is so small, however, that it is not possible to run a systematic programme, especially as both professors have other research interests as well. The only exception is forestry economics, with a joint programme run by the School of Forestry and the Centre for Regional Studies at Umeå (CERUM). There is an obvious regional interest for a programme in the economics of the roundwood industry (see e.g. Andersson, Kallio and Seppälä 1986, Löfgren, Bångman and Wiberg 1986, Johansson and Löfgren 1985). Even with this connection, the scale is very small.

Elsewhere there are only occasional individual researchers working in this field and communicating with an international audience: Marian Radetzki, formerly at IIES and now at SNS, with a longstanding research programme in mineral resources (see Radetzki 1989a and 1989b) and Fred E. Banks at Uppsala, who does some work on energy resources along with other subjects (e.g. Banks 1976).

There are two general remarks to be made in connection with this necessarily brief survey. The first illustrates our point about the internationalization of academic economics. Most of the resource and environmental economics practised in Sweden is indistinguishable from that practised elsewhere. Mäler and Radetzki publish their work in international journals. Forestry economics is an exception; for obvious reasons Sweden and Finland have a special interest in and a special audience for this subject. But if interest continues to move in the environmental direction, its international aspect will become more pronounced.

The second comment returns to the question of scale. Even if this field is getting bigger, it is still quite small. If every economics 
department and research institute tries to maintain a presence in the field, the specialists will be completely isolated and it will be impossible to sustain a coherent research programme. A rough guess is that there might be room for two centres of teaching and research in Sweden, perhaps one focused on forestry and other extractive industries, and one on environmental issues, allowing naturally for a certain overlap. We will come back to the general organizational question later.

\section{INTERREGIONAL ECONOMICS}

Spatial and regional economics is an example of a small, highly specialized subfield of economics, in this case cultivated in Sweden mainly by a small group at Umeå led by Åke Andersson and Tönu Puu. It is interesting that even on this small scale the process of integration with the international literature has gone a long way (Andersson, Anderstig and Hårsman 1990).

Andersson and his collaborators are close to the mode of 'traditional' regional economics. Their work has appeared in the Regional Science and Urban Economics journal (Andersson and Kuenne 1986) and in the Handbook of Regional and Urban Economics. Puu has made significant contributions to what might be described as abstract spatial economics (cf. e.g. Puu 1979). His work can be most readily compared with that of Martin Beckmann (who has divided his career between Germany and the United States). Beckmann and Puu have also collaborated (Beckmann and Puu 1990).

\section{INTERNATIONAL ECONOMICS}

The history of research in international economics in Sweden in the 1980 s is very largely a history of the Institute for International Economic Studies. Before the 1980s, the institute had a small and young permanent staff, and many of the most active researchers were visitors from abroad. But over the last ten years or so the young staff members have matured to become first-rate researchers, many of whom have earned a solid reputation in the worldwide economics profession. This section deals with their contributions to international economics. Only a selection of the most significant references can be given, since a full bibliography would be too lengthy.

The neoclassical theory of the determinants of the direction of trade continued to be developed. More general results on the effects of factor endowment and technology differences on trade patterns were 


\section{Views of the international evaluation committee}

obtained, the relationships between factor movements and goods trade were studied, and the welfare effects of factor mobility were examined. Lars E. O. Svensson wrote several of the articles on these subjects, for example Hamilton and Svensson (1983 and 1984), Markusen and Svensson (1985), Ethier and Svensson (1986).

During the 1980s the attention of trade theorists shifted to conditions of imperfect competition and intra-industry trade. Henrik Horn was among the early workers in this area. His dissertation (Horn 1983) generalized the treatment of demand in these models. Later he collaborated with Wilfred Ethier to re-examine the formation of customs unions in a world with monopolistically competitive trade (see Ethier and Horn 1984).

The recognition of imperfect competition and imperfect information also led to some new arguments for supporting infant industries, and for industrial policy more generally. Examples of major IIES contributions in this area are Flam and Helpman (1987a, 1987b) and Grossman and Horn (1988).

The most substantial and influential contributions by IIES researchers are concerned with intertemporal aspects of trade. This was also a new development of the late 1970s and 1980s, and it led to a conceptually more satisfactory analysis of international borrowing and lending, government budget deficits, the time-consistency of policy, and related issues.

On the microeconomic side Lars E. O. Svensson wrote several articles in collaboration with Nancy Marion, for example Marion and Svensson (1984), on the effects of oil price increases on trade patterns and the terms of trade.

In the 1970s several IIES members, including Lars Calmfors, Assar Lindbeck and Hans Söderström had studied macroeconomic models of the international transmission of inflation; worthy of special mention are Calmfors (1978) and several papers in Lindbeck (1979). This work had its grounding in earlier Keynesian and Scandinavian (Aukrust) models of small open economies, but offered greatly improved analyses of wage and price determination, and of the relationship between short-run and long-run aspects. In the 1980 s there was a move towards issues connected with labour markets (cf. pages 130-3).

The 1980s also brought an emphasis on more explicit microfoundations for macroeconomics, with rigorous modelling of expectations, intertemporal choice and equilibrium. This was an international trend, and the IIES was not a mere participant but was among its leaders. Torsten Persson's dissertation (Persson 1982) was an early and 
significant contribution here. Svensson and Razin (1983) and Persson and Svensson (1985) are important re-examinations of the HarbergerLaursen-Metzler (HLM) effect. The HLM idea is that a deterioration in the terms of trade reduces a country's wealth, and thus its savings for a given level of current income. This tends to impair its current account balance. Svensson and Razin, along with Persson, constructed models with explicit intertemporal consumer choice. This introduced new aspects such as intertemporal consumption substitution, and the distinction between temporary and permanent terms of trade shocks. Intertemporal choice models evolved into research on fiscal policy, which will be discussed on p.141.

Empirical research in international economics at the Institute has been particularly noteworthy for its focus on the problems of less developed countries. Carl Hamilton has worked extensively on the effects of non-tariff barriers to trade, and is a leading authority on the Multi-Fibre Arrangement, a series of restrictions of Byzantine complexity on the world trade in textiles and garments. His publications in this area include Hamilton $(1985,1986)$. Other work worth mentioning includes the study of foreign investment especially in mineral resources, for example Radetzki (1982) and Radetzki and Van Duyne (1984).

The output of all this research activity is very impressive, unparalleled in Sweden during this period and matched by few other institutes of comparable size anywhere in the world. During the period 1980-9 permanent members of the institute published seventy-five articles on international economics, nearly half of them in top-ranking international journals (American Economic Review, European Economic Review, Economic Journal, Journal of Political Economy, Quarterly Journal of Economics, Review of Economic Studies, Journal of International Economics, Scandinavian Journal of Economics, Economica), and the rest in other international journals or conference volumes. Most of this work occurred after the publication of the North-Holland Handbook of International Economics in 1983, but any revision of that volume will have to include numerous citations to the contributions of IIES members. In development economics there were over 30 publications in international journals and books. (And these numbers do not include the Institute's numerous publication credits in labour economics, macroeconomic and microeconomic theory, and some other areas.)

Outside the IIES very little research in international economics in Sweden in the 1980 s has led to substantial scholarly publication. Bo Södersten's textbook (1980) enjoyed international success, but he 


\section{Views of the international evaluation committee}

moved away from research, and has only recently returned. At the IUI, Birgitta Swedenborg (1979) studied the decisions of Swedish multinationals. Her work was among the earliest empirical demonstrations of the new 'transactions approach' to multinational enterprises. This theory regards direct foreign investment as a vehicle for getting round the informational problems that make it difficult to trade in the intangible assets of firms - for instance technology and managerial skills - in arm's length markets. Since exports of goods can also serve similar functions, exports and investment can complement rather than substitute for one another. Swedenborg's verification of such implications was significant to the success of the new view of investment. Other work on multinationals is mostly in the context of less developed countries; for example, Blomström (1986a and 1986b) has examined the effect of the presence of multinationals on productivity and concentration in Mexican industry.

The Swedish International Development Agency (SIDA) and various international development organizations have sponsored much work on less developed countries. At the Stockholm School of Economics this is led by Mats Lundahl. There is also substantial interest in development economics at Gothenburg University. Such consulting and sponsored research forms a large proportion of Swedish work in development economics, and little of it reaches scholarly publication standards.

\section{PUBLIC FINANCE}

Recent Swedish research on the microeconomic side of public finance (allocative and distributional issues) again illustrates the extent of the integration of Swedish economics into the international profession. Sören Blomquist (formerly of Stockholm University, now Uppsala University) has written several articles on estimating the effects of taxation on labour supply, for example Blomquist (1990). He allows non-linear and even non-convex budget sets, repeating with Swedish data and in some respects extending Hausman's research in the United States (cf. Hausman 1985: 243, 246). Peter Bohm, also at Stockholm University, has worked on theoretical and empirical aspects of estimating the demand for public goods (Bohm 1984), and on issues of tax policy for environmental problems (Bohm and Russell 1985). His recent internationally published writings include several articles in the New Palgrave (Bohm 1987a), and a new edition of a well-received textbook on welfare economics (Bohm 1987b). Peter Englund, formerly of IIES and now at Uppsala University, Mats Persson of 
IIES, and David Brownstone, have collaborated on research into the effects of tax reform on housing (Brownstone, Englund and Persson 1988a and 1988b). Noteworthy aspects of this work include a calculation of the effects of large changes in progressive tax schedules, when individuals have non-linear budget constraints. Lars-Gunnar Svensson (Lund University) and Jörgen Weibull (IIES) have worked on progressivity and efficiency in income taxation. Svensson and Weibull $(1986,1987)$ establish the upper bounds for marginal tax rates which are determined by considerations of Pareto optimality alone and which are therefore valid for all levels of inequality aversion in the government's objective function. Ingemar Hansson (Lund) and Charles Stuart (University of California, Santa Barbara) have collaborated in research on various aspects of public economics. They computed the marginal deadweight cost of tax revenues in Sweden and found it could be infinite for plausible parameter values (Hansson and Stuart 1985a); they constructed an overlapping generations model of pay-as-you-go social security (1989).

A new but rapidly growing area of research in public economics tries to integrate the politics of decision-making into economic models of tax and expenditure policy. The result is an explanation of economic policy choices as the equilibrium outcomes of a political process. Several members of the IIES have been among the pioneers of this topic. Assar Lindbeck and Jörgen Weibull have already published some articles in major journals (Lindbeck and Weibull 1987 and 1988a). The work of Torsten Persson with Guido Tabellini (1990) also falls in this area, but it has a more macroeconomic orientation, and is discussed along with other more voluminous literature on the macroeconomics of fiscal policy in the next section. At Lund, Hansson and Stuart (1985b) constructed a model of voting over tax schedules and argued that the progressivity of the Swedish tax system exceeds that most preferred by the median voter.

\section{ECONOMETRICS}

For a long time Herman Wold was the leading figure in the field of econometrics in Sweden. Wold himself moved between pure theory and the application of new econometric methods, as indicated by the title of his 1983 book with Reinhold Bergström, Fix Point Estimation in Theory and Practice (Bergström and Wold 1983). In recent years Swedish economists, sometimes in collaboration with academic statisticians, have focused on the serious application of advanced methods rather than on the creation of new econometric techniques to 


\section{Views of the international evaluation committee}

deal with novel contexts of estimation or hypothesis-testing. A representative sample might include Anders Klevmarken's booklet $O n$ the Complete Systems Approach to Demand Analysis (Klevmarken 1981). This is an excellent exploration of Swedish data using an approach that post-dated Wold's own Demand Analysis (Wold and Juréen 1952).

The work of Reinhold Bergström and P.-A. Edin on 'Time Aggregation and the Distributional Shape of Unemployment Duration' (Bergström and Edin 1991) fits in with the Uppsala focus on labour economics and with the paper by Karl-Gustaf Löfgren mentioned on pages 133-5. The point of the paper is to study the robustness of methods applied to study the duration of unemployment and especially the sensitive issue of 'duration dependence' or the dependence of the exit probability on the length of a spell of unemployment.

Lennart Flood (1985a and 1985b, and Flood and Tasiran 1990) has written on so-called Tobit estimators comparing alternative estimators at different sample sizes and Hans Nyquist (1991) has treated the design of discrete response experiments with certain environmental questions as the intended application.

Finally, in Sweden as elsewhere, there has been activity in the construction and testing of macro-econometric models (see e.g. Lybeck et al. 1984 and Löfgren 1991).

\section{MACRO AND MONETARY ECONOMICS}

As has been pointed out above, economic research in Sweden has been directed predominantly towards specialized and applied areas. In the ten years or so there have not been very many systematic research programmes geared to the central areas of economics. This is also true of general macro and monetary economics. Nevertheless several studies and much research have resulted in internationally significant achievements. It is characteristic that even here there is a significant connection with research in specialized areas such as international or labour economics. The important role of the IIES is clear in many of these achievements.

A couple of Swedish contributions are noticeable in the reconstruction of the foundations of macroeconomics, which has been an active field over the past two decades. Lars E. O. Svensson (1980 and 1986) developed some models of equilibria with stochastic rationing and with dynamic price setting. These have been important contributions. Bo Axell's work on search theory, which he started during the 1970s in 
his thesis, continued in the 1980 s concurrently with the other international literature on the search equilibrium approach to macroeconomics (see e.g. Albrecht and Axell 1984 and Albrecht, Axell and Lang 1986).

As we have seen on pages $135-8$, the studies of the long-run effects of stabilization policies, conducted mainly at IIES, focused on the specific problems of small open economies in the early 1980s. During the 1980 s this work on open economies expanded into a systematic effort on intertemporal models of the macroeconomy and economic policy. The research on the role of commitment and credibility in dynamic macroeconomic policy-making has been an active and interesting research topic during the 1980s. Interest has focused on a fairly wide range of issues in fiscal policy. These include taxation policies, the financing of government deficits, and the structure of government debt. Some of this work also has important implications for open economy problems. Torsten Persson has been most actively involved in this direction, often in conjuction with Henrik Horn, Mats Persson and/or Lars E. O. Svensson. Guido Tabellini and Laurence Kotlikoff have been involved as foreign collaborators. (See e.g. Horn and Persson 1988; Kotlikoff, Persson and Svensson 1988; Persson, Persson and Svensson 1987 and Persson and Tabellini 1990.)

Quite recently, this line of work has been extended to include positive theories of government decision-making and politics and their consequences on macro- and microeconomic performance. The area can thus partly be classified as public economics. The new book by Persson and Tabellini (1990) is a good general source of references to all this work on credibility and the politics of economic policy-making.

In macroeconomics there has also been some other useful research on fiscal policy, taxation and government finance using dynamic general equilibrium modelling (e.g. Lindbeck and Weibull 1986, 1988b). Further research on price rigidities and fix-price models, which was quite popular in the 1970s, is worthy of mention. Torsten Persson and Lars E. O. Svensson (1983, 1984) considered the significance of expectations in models with Keynesian rigidities. Some of this research focused on novel applications in open-economy contexts (e.g. Cuddington, Johansson and Löfgren 1984) and questions of taxation, and cost-benefit rules in the presence of unemployment (e.g. Johansson 1982 and Svensson and Weibull 1984). Research on trade union behaviour and wage formation, discussed in detail on pages 131-2 has also had some important connections with macroeconomic research (e.g. Calmfors and Driffill 1988 and Lindbeck and Snower 1988).

In monetary economics the work on cash-in-advance models of 


\section{Views of the international evaluation committee}

money demand conducted at IIES by Lars E. O. Svensson and to some extent by Peter Englund, represents an important piece of theoretical research (cf. Svensson 1985 and Englund and Svensson 1988). Other work in this field has taken place at several institutions. Theoretical and econometric studies of asset markets and their connections with the macroeconomy have recently been pursued (e.g. Bergström and Rydqvist 1990, Hörngren and Wredin 1989, Wihlborg 1990 and Werin 1990). Lars Jonung has analysed the formation of inflation expectations and questions of monetary history in Sweden (see e.g. Jonung and Laidler 1988).

The emergence of financial economics or finance as a systematic field, and the establishment of study programmes, has been a common international phenomenon in the past decade. Sweden followed the pattern fairly late, with the Stockholm School of Economics and Gothenburg and Uppsala Universities now as the main centres. As we have just noted, some of the empirical work on asset markets has been published recently. It is likely that extensive research into asset pricing, the performance of financial markets and international finance will be done in the future. Several theses are also in progress in this area.

Finally mention must be made of a significant amount of research into the history of economic thought in Swedish macroeconomics and economics generally (cf. e.g. references in Chapter 2 above and Siven 1985).

\section{MICROECONOMICS}

Microeconomic research in Sweden has also been predominantly applied and empirical. There has been a modest amount of work on basic microeconomic theory. Here we can start by mentioning the research on general equilibrium and welfare theory, mainly carried out at Lund in the 1970s and continuing into the 1980s. In the last decade Lars-Gunnar Svensson (see e.g. Svensson 1983, 1988 and 1989) has been the scholar most involved in this direction. This work usefully complements and contributes to applied fields such as law, economics and the public sector (see e.g. Skogh 1982 and 1989, Skogh and Stuart 1982 and Lyttkens 1988), and the labour market (cf. pages 130-3 above).

The theory of stability and price setting were analysed by Lars E. $O$. Svensson (1984) and by Ante Farm and Jörgen Weibull (Farm and Weibull 1987, Farm 1988). Nils Gottfries (1986) considered some empirical aspects of price dynamics. Recently some basic research on 
game theory has been started (e.g. Carlsson 1988 and Weibull 1988, 1989), but has not yet been published. Thus it is too early to say much about its prospective international standing. It is interesting to note that so far there has been no systematic effort to apply game theory to industrial economics - an approach which has flourished internationally in the 1980s.

Applied microeconomic research has been fairly extensive in some areas not previously covered. The empirical and econometric studies of production behaviour and the measurement of productivity, most of them carried out in Gothenburg by Lennart Hjalmarsson and others, represent major attempts to develop new methodology and to apply it to Sweden and other, mostly Nordic, countries (see e.g. Försund and Hjalmarsson 1983, 1987). This work has also resulted in a large number of Ph.D. theses. Microeconomic modelling of energy and production has also been developed in recent years (e.g. Bergman 1988, Bergman and Lundgren 1990). Questions concerning allocation, growth and structural change, such as learning, innovations, research and development, and organizational behaviour, have continued to represent an active area of research. ${ }^{2}$ These topics have been extensively studied mainly at the Industrial Institute for Economic and Social Research (IUI) and to some extent elsewhere (see e.g. Eliasson 1988, Pelikan 1989 and Jungenfelt 1986).

The study of household behaviour in the HUS project run by Anders Klevmarken and his colleagues is an example of a large-scale applied project (see e.g. Klevmarken 1986 and Flood 1988). Among other results it provides a systematic panel data base for use in a variety of research contexts including the market $v s$. non-market activities of households, labour supply, housing, mobility questions and distributional issues. Some of these topics have links with research at other universities, and these connections should be developed further.

In microeconomics separate mention must be made of health economics, primarily at the Institute of Health Economics at Lund University (IHE), where it constitutes a systematic programme of research (see e.g. Persson et al. 1988 and Lindgren and Persson 1989). ${ }^{3}$ The other areas of microeconomic research which are represented by a significant amount of Swedish work, such as studies of the housing market and regional economics, were discussed on pages 130-40 above. This material could have been grouped in different ways, and our classification was the result of our desire to emphasize the role of specialized research. 


\section{Views of the international evaluation committee}

\section{CONCLUSIONS}

The main conclusions to emerge from our discussion of contemporary economics research in Sweden may be summarized as follows:

1 Twice in the past, important and uniquely Swedish schools of research led to revolutions in economic thinking. In the integrated world economy of today, and with an economics profession that is similarly integrated, such separate national movements are unlikely to recur. Any new pathbreaking contributions will have to be made within the framework of the rapid international communication among scientists that now obtains.

2 Swedish research in economics has a very respectable present, and in the most advanced departments and institutes it has become well integrated into the international economics community. IIES is by far the most advanced institute with excellent results.

3 Much Swedish research is concerned with, or is at least motivated by, special Swedish problems. A significant amount of this kind of work is receiving international as well as national attention.

4 It is characteristic that systematic and large-scale research programmes and contributions have mostly been made in special areas. Labour economics and international economics have been the biggest fields of research. Regional economics, public economics and natural resources have been other important special fields. Research in econometrics has been geared towards applied econometrics, and most of the research is an integral part of the particular areas. Relatively little research on econometric methods has been done.

5 In addition to these fields a significant amount of research has also been done in other areas. We have discussed this under the general headings of macro and monetary economics and microeconomics. The scale in these areas has been smaller in the special fields indicated. and their boundaries have not been as clear-cut. 


\title{
7 Organization of research
}

\author{
Avinash K. Dixit, Seppo Honkapohja and \\ Robert M. Solow
}

\section{AN OVERVIEW}

We start our analysis of the organizations conducting economic research by looking briefly at the market for doctors of economics. While the main aim of Ph.D. programmes is to produce researchers, quite a few of those with doctoral degrees go on to other careers, often after spending some time in research. These careers may be in business or public administration, and traditionally they have not required a Ph.D. level of professional skills. A change in the professional requirements is already taking place, and it is likely to become more pronounced in the future. Highly trained economists are needed to an increasing extent in positions outside the universities and the major research institutes.

If we include non-research posts and employment in foreign countries as additional career possibilities besides teaching and research, the main features of the market for doctors of economics can be described by figure 7.1 .

A career in a university is obviously the most important of the possibilities open to a young Ph.D. However, the academic sector of

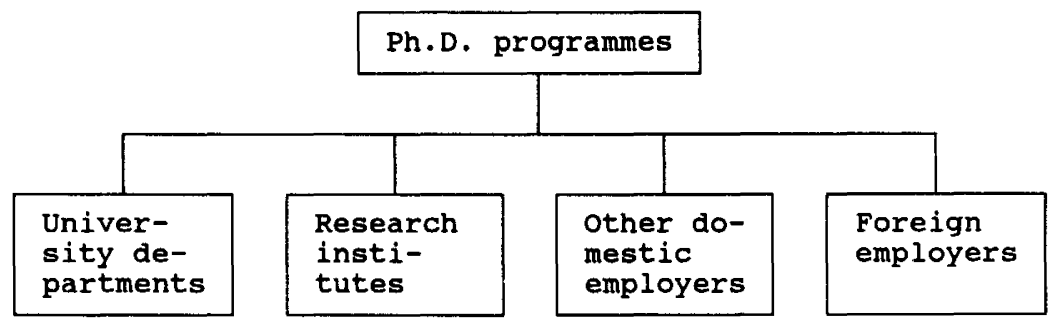

Figure 7.1 The market for doctors of economics 


\section{Views of the international evaluation committee}

the market does not operate smoothly over time, due to the small size of the country and for certain other reasons. Other research institutes, whether independent or associated with a university, represent an important section of the market for doctors of economics.

In the past the public sector has hired surprisingly few economists for professional purposes. This is said to apply particularly to the Central Bank and the Ministry of Finance (cf. Chapter 4). This seems to have been more a problem of the supply rather than demand. However, increased hiring is already taking place, and the change is likely to become pronounced as Sweden integrates with the European Community.

In recent years the private sector has been engaging an increasing number of economics doctors, notably in banking and finance. Some of the biggest firms in industry are also potential employers for professional economists, provided that the postgraduate education system can provide an appropriate training for their rather specialized needs. Skills needed in the analysis and forecasting of relevant aspects of specific product markets are important in this respect.

Employment opportunities in foreign countries are of three main kinds. First, a number of $\mathrm{Ph}$.D. students at Swedish universities come originally from one of the developing countries, and most of them subsequently return there. Second, international organizations, such as OECD, IMF and the World Bank, hire professional economists with a Ph.D. degree. This part of the market may be an area of growth in the future as a result of European integration. Careers in foreign universities are the third category in this segment of the market.

Focusing on Swedish research positions the overall picture can be summarized as in figure 7.2. Here the university economics departments, perhaps somewhat artificially, have been separated from university-based and other research institutes. This distinction has been made for the sake of evaluation, since the problems faced are to a large extent different.

The economics departments at the different universities certainly represent one of the main types of research organization. Excluding the regional colleges, there are six economics departments in the universities of Gothenburg, Lund, Stockholm, Uppsala and Umeå, and at the Stockholm School of Economics (cf. Chapter 1 above). All these offer the Ph.D. degree, so economic research is conducted by both staff and postgraduate students. The integration of postgraduate training programmes and research is the main characteristic of the university departments that distinguishes them from pure research institutes. In the ensuing discussion we have grouped certain units 


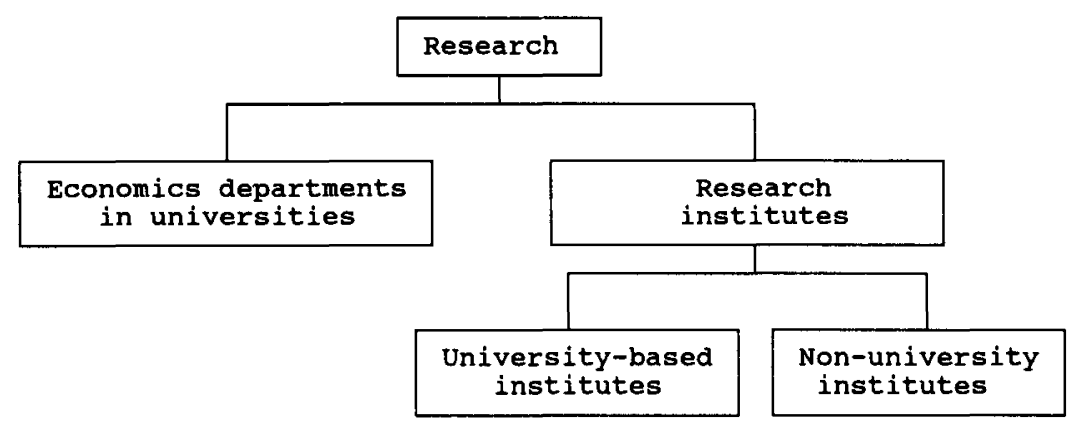

Figure 7.2 Organization of research

together, since they appear to work together to a significant extent. A notable example is the Stockholm School of Economics, which also has a department of finance and a department of international economics and geography. Another example is the department of forest economics at the College of Forestry in Umeå.

Those institutes which have economic research as their primary function can be classified as university-based or non-university-based research institutes. According to our earlier distinction between university departments and research institutes this means that the former group consists of specific research institutes like the Institute for International Economic Studies (IIES) and the Swedish Institute for Social Research (SOFI) at Stockholm University, and the Institute of Health Economics (IHE) in Lund. These possess many of the typical characteristics of general research institutes, but they are also directly associated with teaching. They do not grant Ph.D. or other academic degrees. Moreover, the staff of these institutes consists partly of Ph.D. students who are in the process of doing research for their theses. It should be noted that these institutes have partial funding (or even main funding in the case of IHE) from private sources.

Besides IIES, SOFI and IHE there are also some other universitybased institutes and centres of various kinds. They are essentially administrative units, facilitating various practical aspects of research. They include the Economic Research Institute at the Stockholm School of Economics (EFI) and the Centre for Regional Studies in Umeå (CERUM) at the University of Umeå. Typically, the senior staff of these places are also professors of economics (or related subjects). We have not separated EFI and CERUM from university departments.

The three main non-university research institutes are the Industrial 


\section{Views of the international evaluation committee}

Institute for Economic and Social Research (IUI), the Trade Union Institute for Economic Research (FIEF) and the National Institute of Economic Research and the Economic Council (KI-ER). Although the goals and structure of research at these places are comparable to those of the university research institutes, there are differences in other respects. First, recruitment policies are directed at least in principle only at people who have already completed a Ph.D. degree. Second, the connection with postgraduate and undergraduate teaching exists only in so far as specific individuals are associated with a university. The research profiles of most university-based and other institutes do not differ very much, since they all focus to a large extent on highquality applied and empirical work. The exception is IIES, whose research orientation is more theoretical than the others. However, even there a significant proportion of the research activities are motivated by empirical or policy issues. IIES's general profile would probably be regarded as 'middle-brow' by international standards, since highly abstract and mathematical economic theory has not predominated there.

\section{UNIVERSITY DEPARTMENTS}

A general characteristic of the Swedish university system is that many of the economics departments are small by international standards (cf. table 7.1). Apart from causing some difficulties in the postgraduate training which will be discussed in Chapter 8 below, the current organization whereby research is scattered over several small departments also can mean potential problems for the research itself. During our visits it was evident to us that there were too few research groups in several though not all the departments. Successful working groups or teams in particular areas can often do a lot to promote active, productive and innovative research environments.

The recent improvement in operations in the department at Uppsala provided a good example of this kind of team spirit. The departments at Stockholm University and the Stockholm School of Economics, where the cooperative element is meagre, are more or less at the opposite end of the scale in this respect. There are far too few group undertakings and to some extent even an inadequate emphasis on high-quality research. These problems may be due to some extent to the effects of the location in a large city, but IIES and SOFI provide examples to the contrary. It should be noted, however, that professors at the Stockholm School of Economics have a relatively heavy undergraduate teaching load. A special effort should be made to 
Table 7.1 Staff in departments of economics, 1 July 1990

\begin{tabular}{llllllll}
\hline Department & $G U$ & $H H S^{\mathrm{a}}$ & $L U$ & $S U^{\mathrm{b}}$ & $U m U$ & $U U$ & Total \\
\hline $\begin{array}{l}\text { General chairs } \\
\text { Specialized }\end{array}$ & 2 & 6 & $3(1)^{\mathrm{d}}$ & 7 & 3 & 2 & $23(1)$ \\
$\quad$ chairs & $3^{\mathrm{c}}$ & $3(1)^{\mathrm{f}}$ & $1^{\mathrm{g}}$ & $6^{\mathrm{h}}$ & $2^{\mathrm{i}}$ & $3(1)^{\mathrm{k}}$ & $18(2)$ \\
$\begin{array}{l}\text { Docents } \\
\text { Forskar- }\end{array}$ & - & 2 & 2 & 6.5 & 1 & - & 11.5 \\
$\begin{array}{l}\text { assistents } \\
\text { Lektors }\end{array}$ & - & - & $4(1)$ & 5 & 3 & 3 & 15 \\
Adjunkts & $9(2)$ & $4(2)$ & $13(1)$ & 11 & 3 & 9.5 & $49.5(5)$ \\
Total & 5 & - & 3 & 5 & 5 & 8 & 26 \\
\hline
\end{tabular}

Notes: "HHS is not organized in the same way as the university departments. The main difference is that HHS is divided into more departments and that the teaching duties of the professors and all other teachers are about the same, i.e. between 100 and 200 hours a year. The table includes economists from the departments of economics, financial economics and international economics including economic geography.

IIES and SOFI are included.

'Professors of international economics are included, adjunct professors are not.

${ }^{a}$ All numbers in brackets indicate vacancies.

- Development economics; financial economics; econometrics.

'Esp. energy and environment, economic policy and health economics.

${ }^{8}$ Economics, esp. public economics.

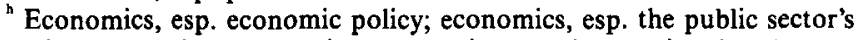
policy; theoretical economics; economics, esp. international and monetary problems (IIES); labour market policy (SOFI); economics, esp. evaluative labour market research (SOFI).

'Econometrics; regional economics.

'Economics, esp. capital market analysis; economics esp. business taxation; community economics.

design areas of expertise and research team work in these places. More weight should be given to basic research as a matter of policy at the Stockholm School of Economics.

The problem of establishing common research interests and expertise among the senior staff is often made worse by the astonishing degree of inbreeding and immobility in the Swedish university system. Most students and staff stay in the same department throughout their student years and their subsequent careers.

Departments do not actively recruit students or staff from other universities. Cross recruitment would increase competition between departments, and should be encouraged. Immobility also hampers the specialization which might go some way towards overcoming the problems of small-scale departments. The risk that the teaching and 


\section{Views of the international evaluation committee}

research may not be keeping up with the times is aggravated by the immobility and inbreeding. The research expertise of the teaching staff and the interests of the Ph.D. students are by no means always well matched. Every department has some postgraduate students who have to work on their own, as no member of the teaching staff works in the student's area of interest.

Another consequence of inbreeding seems to be that the staff show little interest in getting new ideas from visiting teachers from other Swedish institutions or from abroad. Some departments, such as Lund and Stockholm University, do not seem to be very keen on running an active and high-quality programme of visitors. Other departments, understandably but not altogether wisely, limit this activity to their own special interests. Such attitudes should be changed; where programmes including guest lectures and seminars are arranged, the postgraduate students and junior staff often find them very inspiring. The shortage of contacts has also meant that there are relatively few joint research projects involving staff in different departments in Sweden or internationally.

The reasons for this immobility and inbreeding are complex. In addition to the attitudes of students and staff and the university system as a whole mention should also be made of the funding system for postgraduate studies, the relatively low academic salaries, and the problem of two-career families. These are all contributory factors. Inbreeding will probably continue to characterize the Swedish academic system, but attempts should be made to mitigate its potentially harmful effects. Ways should also be sought for increasing mobility internationally and, above all, in Sweden.

A general problem in the university departments seems to be the lack of systematic career paths in research and teaching. The problem is greatest for those who have recently acquired their $\mathrm{Ph} . \mathrm{D}$. degrees. The opportunities in a university department are to obtain a research position with some teaching duties (forskarassistent) or a lectureship (högskolelektor). The first of these naturally provides good opportunities for research, but the positions are far too few - far fewer than the chairs (cf. table 7.1). Lecturers on the other hand have very limited time for research as a result of their heavy teaching load. The shortage of junior staff actively involved in research also means that there are too few people to inspire and help students doing doctoral research. In the next chapter we will discuss the incentive aspects of the current system in more detail.

It should be noted that the department at Lund is to some extent an exception to this pattern. It has a reasonably balanced staff structure 
with a relatively large number of docents or tenured lectureships with certain research obligations. In Lund the lecturers' teaching duties have been reduced. These are surely steps in the right direction.

The physical facilities in the various departments were adequate on the whole, although there are also certain problems. In some places, particularly in Gothenburg, Stockholm and Uppsala University, there is a noticeable shortage of working space for postgraduate students. Some departments provide too little assistance and information about specialized computer programs, although the hardware generally seems adequate. The library resources at Umeå are in noticeably poor shape.

\section{UNIVERSITY-BASED RESEARCH INSTITUTES}

The Institute for International Economic Studies (IIES), established in 1962, has had a key role in economic research in Sweden during the 1970 s and 1980s. It has currently five professors and six docents. It is the only institute with a strong international orientation as regards both standards and research ambition. The breadth of its contacts with researchers in other countries is another very notable characteristic. Attitudes at IIES are very entrepreneurial. In these respects it sets the standard for other institutes in Sweden.

In recent years the senior staff of IIES have taken on a good deal of postgraduate teaching in the Stockholm area, after having involved themselves very little previously. They now do about as much teaching as university professors. Over the years IIES has also produced a significant number of professional economists for careers outside the Institute. Although the Institute takes on only a relatively small number of postgraduate students to work on theses, it has been highly successful in the little that it has done, with a success rate of about 80 per cent. It may be noted that several of the theses done at IIES have been defended in HHS.

As has been noted, IIES is a very academic but middle-brow institute in the focus of its research. It does not aim to produce a large amount of abstract theoretical research, although such work is sometimes produced by certain individuals. A fair proportion of its research is empirical. Typically the theoretical and the empirical research is grounded in policy or other applied considerations, although few individual studies in themselves have any direct policy application. The links with the recently established Economic Council (Ekonomiska rådet) is an exception to this prevalent pattern.

In the past international economics research predominated at IIES, 


\section{Views of the international evaluation committee}

but in the 1980s the interests of the Institute extended into other areas of macroeconomics, labour markets and public economics. Thus, for a university institute, IIES seems to maintain a reasonable balance in its research. The environment at IIES is very conducive to research. The strict standards, the active research staff and the large number of foreign visitors are all important factors here. Its output is consistently of a high international standard. Thus taken as a whole IIES is a very successful operation.

The other university-based research institutes are quite different from IIES. Both the Swedish Institute for Social Research (SOFI) at Stockholm University and the Swedish Institute for Health Economics at Lund (IHE) work in specific areas of applied economics, and they have a strong interdisciplinary character.

SOFI was established in its current form in 1972. About a third of the staff are economists, the rest are sociologists. Currently there are two professors and two docents in economics. The economic research at SOFI focuses mainly on the labour market and social policy. Most of its research is geared to applications, and this has resulted in a relatively strong emphasis on Swedish problems of relevance to policymaking. As was pointed out on pages 131-2, SOFI's research profile was not previously very international, but recently it has become much more so.

Much of SOFI's work is concerned with the preparation of Ph.D. theses, work which its environment appears to encourage. Members of the senior staff teach at Stockholm University. SOFI is also responsible for an undergraduate programme in industrial relations.

IHE was founded in 1979 with a definite focus on research in health economics. Its funding comes from private sources. IHE adopts various approaches: study groups, courses and seminars are all fairly widely used, in addition to research projects. IHE has two staff members with Ph.D. degrees and eight who are postgraduate students themselves. Links with the economics department are quite close, and there is also some cooperation with other departments at Lund. The international links with the United States, Great Britain and other Nordic countries seem to be fairly active.

Looking at the university-based research institutes as a whole we find that they all have quite different identities. There is no single model. IIES, which started as a unit specializing in international economics, has moved on to broad expertise in economics. It has a key role in economic research in Sweden. It could take a more active role in the country, generating research connections and exchanges with other departments. It could also take more responsibility in post- 
graduate education on a national basis. SOFI and IHE are both confined to special areas of applied economic research. Their main duty is to foster research, postgraduate training and international contacts in their own fields. They both appear to be succesful operations.

\section{NON-UNIVERSITY-BASED RESEARCH INSTITUTES}

The major non-university-based research institutes (IUI, FIEF and KI-ER) are important in providing much of the market for doctors of economics. Each one tries to build up a character and a research of its own.

The Industrial Institute for Economic and Social Research (IUI) is over fifty years old; it is a well-established institute with fifteen to seventeen researchers. Over the years many academic economists have spent time doing research at IUI, and in the earlier decades a significant number of the old type of Ph.D. theses were in fact produced there. The institute has a long tradition in industrial economics. It continues to do a good deal of research in this area, but some work is also being done in other major areas. The projects fall mainly under the headings of international and labour economics. The research focuses primarily on applied theory and empirical analysis, but a 'more academic' profile is evidently being envisioned for the future.

The Trade Union Institute for Economic Research (FIEF) has only been in existence since 1985, and has not yet developed any traditions. It has between eight and ten positions for researchers. Its main research areas are labour economics, structural change, and stabilization policy. At present its research focuses on applied theory and empirical work. A stringent academic standard is demanded, and there seems to have been an international orientation right from the start. While it is too early to make any firm evaluation of its work, its aims and its current operations both give good hope for an excellent contribution to research in the future.

The National Institute of Economic Research (KI) has a present research staff of about ten people, whereas most of its staff are involved in statistical work and forecasting. In the past KI had a high reputation for research on macroeconomic dynamics and policy analysis, due to one or two very influential directors (in particular Erik Lundberg). Since the 1960 s, however, it has been engaged primarily in forecasting and to a much lesser extent in research. It is currently trying to establish a partly new identity by building up a research unit 


\section{Views of the international evaluation committee}

for macroeconometric and applied general equilibrium modelling. Such a change is most welcome, as it will bring $\mathrm{KI}$ in line with similar institutions internationally.

The Economic Council of the Ministry of Finance, which operates in association with KI, consists of a group of academic economists from different universities which meet regularly to discuss and analyse research areas important to policy-making. It represents a very interesting attempt to improve the relation between research and policy-making. One of its major aims is to raise the status of professional policy-relevant work. If professional economic research is to make a reasonably prompt impact on policy-making, this kind of cooperation must surely be a step in the right direction, even though it is too early to judge its success.

On the whole the non-university research institutes seem to be both necessary and successful operations. The research they produce is certainly professional, but could to some extent be given a more innovative and ambitious slant. An improvement along these lines has also been discussed as an aim for the future. Such declarations of intent should be included as an express policy decision in all the institutes, as it would be likely to reduce the emphasis on the immediate applicability and policy relevance of the operations.

One evident reason for problems regarding innovativeness and level of ambitions in research is said to be the variable and generally not very high quality of the economics doctors produced by the university system. Weakness in theory and in econometrics are said to be the main problem. But the best of the doctors are said to reach a high standard (cf. further below in Chapter 8).

The environment in these institutes seems to be more flexible and productive than in the university departments. A conscious effort is made to create and maintain a productive atmosphere for research. One problem appears to be the lack of any real career paths in research. These institutes are good places for specific projects, and can provide the researcher with a productive period of some years. Most researchers move on to other careers after spending perhaps five to ten years in a non-university-based research institute. Some continue in the academic world, while others pursue a non-research career in either the public or the private sector.

The shortage of researchers at different levels of competence may hinder the development of a rich research atmosphere. The presence of scholars of high repute would help to raise the quality of the research and would provide challenging examples for the younger staff. Experienced researchers of this kind could perhaps lead some big 
long-term team project, such as developing a class of models for policy analysis. They would be expected to move on eventually to a university, and the universities should be made to compete in acquiring people of this calibre.

\section{RESEARCH FUNDING}

Before discussing research funding it is necessary to make a clear distinction between scholarly research and routine studies. By the former we mean both theoretical and empirical research which aims to extend scientific knowledge in economics. It is ambitious and requires substantial creativity and innovation in theoretical frameworks, data and methods. The work is primarily oriented towards the international research community. In contrast, by the latter we mean studies of particular problems of local interest. The work typically utilizes known data and methodology, and its primary target is outside the research community, e.g. government bodies, business or the general public.

Sweden produces a continual supply of competent applied and policy-oriented routine studies in the various university departments and research institutes. This can be attributed to a number of factors, of which three can be singled out: a strong tradition in this kind of work, good data sets, and the availability of funding specially linked to it (cf. Chapter 3). The amount of research being produced in certain applied areas is admirable for such a small country, the best example being the labour market field. However, the existence of large tied funds also has its disadvantages.

The problem of quality control is of crucial importance, and it must be faced firmly. Admittedly there are difficulties when it comes to publishing applied work relating to issues and conditions in a small country in the best international journals. At the same time it is evident that in some areas the level of ambition in the research is simply not high enough. In development economics, for example, the number of routine country studies produced does seem excessive. Incentives and working methods must be designed to ensure the high quality of applied work. For instance, the existence of active communities of economists should be ensured; these should be national study groups in specific fields, networks or other collaborative arrangements with other small countries. Competition, constructive discussion and debate all generate mechanisms for quality control.

The current system is clearly not producing an adequate volume of ambitious, innovative scholarly research in applied economics. This is 


\section{Views of the international evaluation committee}

probably due partly to the system of post-graduate training, but partly also to the system of excessively tied funding. An obvious example of this is econometrics. Good data sets are available, but very little research is being done on the development of new econometric methods. Practically all econometric work in Sweden refers to applied econometrics, which so far as it goes often achieves a high standard. Examples are the microeconometrics research projects at Gothenburg, IUI and elsewhere (see Chapter 6).

The practice of adopting methodological innovations from abroad without trying to develop any in Sweden slows down the spread of new techniques to applications. It also means that in an international comparison Sweden will not be at the very forefront of applied research.

Another aspect of a badly designed tied funding system is that it can encourage the establishment of very specialized chairs. The forthcoming chair in recreational economics, at Umeå, is an obvious example. While there may be a short-term interest in taking up such highly specialized topics, there are at least two problems. First, quality control can easily run into trouble. A small country should not waste talent by appointing mediocre talents to professorships. The risk of this happening is increased by the creation of narrow and internationally unusual specializations. Second, the short-term considerations underlying the establishment of these chairs may prove to be far less compelling in the future. Since chairs are often held by the same person for twenty to twenty-five years, and the specialization attaching to a particular chair is not easily changed even when it becomes vacant, the system is liable to a good deal of unproductive investments. These problems may not be removed by the forthcoming shift of decision-making about chairs to the local (university) level.

Naturally, it should be possible to allocate resources to certain very specialized needs. But the special funding of particular research projects is a better way of doing this than creating very specialized chairs. First, the competition for such funds means that more researchers become interested in the designated area resulting in higher output. Second, such arrangements are by their very nature more flexible, which means that changing needs can be better catered for.

These criticisms are of course only directed at excessively narrow or otherwise unjustifiable field specifications. Some specialization in chairs is standard practice internationally. Fields such as 'international economics' and 'public finance' are recognized as specifications which will continue to be relevant in the future. A very specialized chair 
should be created only when there is strong evidence of the continuing future importance of the field, and providing the chair can be filled by a well-qualified researcher in open competition with several other high-quality applicants.

\section{THE GENERAL PROFILE OF RESEARCH}

It is evident that there is a general paucity of scholarly research aiming at the international frontiers of knowledge. This is true of all aspects of economics: basic theory, methods, and applied economics. Part of the problem lies in the weaknesses of the system of postgraduate training, to be discussed in the next chapter. But before going into details on this question, it must be said that attitudes, incentives and ambitions generally need changing, and some signs of change are already evident. A case in point are the still fairly low incentives for scholarly research given to professors. Currently, apart from a few isolated individuals, only IIES is systematically involved in frontier research. The research institutes already seem to be moving in this direction.

To give more encouragement to frontier research is a difficult question of science policy. We feel that even small countries should aim to involve themselves in frontier research, since the high standards and ambitions involved are probably the best way of providing a continuous challenge and support for good postgraduate teaching, and inspiring high-quality applied work and professionalism in policy discussion. Since Sweden is a small country, basic research will remain fairly limited in scope if the strict international standards are adhered to. A small country can only have a small number of very gifted postgraduate students and researchers.

Most doctors of economics will in any case be doing applied research, and the big demand for such work provides them with good motivation and strong incentives. The number of economic problems that require professional analysis is not in proportion to the size of the country, and the situation represents a further drain on academic research and puts pressure on the postgraduate training system; it is another factor that limits the volume of frontier research. Government ministries and institutions should aim at increasing their currently small staffs of highly qualified economists.

\section{CONCLUSIONS}

This analysis has led us to the following general conclusions: 


\section{Views of the international evaluation committee}

1 Many of the problems in the research environment in university departments stem from systemic weaknesses: too small a scale, inbreeding, lack of outside contacts, and a sharp division between teaching and research. This saps inspiration and research ambitions. It also adds to the risk of falling behind in relation to the latest developments.

2 The university-based research institutes all have their own special characters. IIES's performance is outstanding, and in several areas the Institute works on the frontier of international research. SOFI and IHE are both successful operations in their own specific areas.

3 The non-university-based research institutes are all at very different stages of development. IUI has a solid tradition, FIEF is new, and KI-ER has recently undergone a radical reorientation. They all seek to maintain stringent standards, and they appear to provide an environment which is conducive to research.

4 The funding system is highly geared towards supporting special applied areas. Some unsatisfactory forms of tied funding have tended to reduce competition and negate research incentives. This has resulted in a general paucity of work on the frontiers of international research. 


\title{
8 Postgraduate education in Sweden
}

\author{
Avinash K. Dixit, Seppo Honkapohja and \\ Robert M. Solow
}

\section{INTRODUCTION}

Swedish economics has a long and distinguished history. Many Swedish economists of the past, and a few of the present, rank among the world's top producers of fundamental conceptual advances in the subject. The policy debate in Sweden has also been enriched by the contributions of its economists.

The emergence of constellations such as the Cassell-Wicksell group or the Stockholm School may be largely a matter of chance. But two necessary conditions are the presence of a base of first-rate talent, and adequate nurture of it. The same conditions are also necessary for efficient performance of the more routine task of continuing research on the Swedish economy and the design of Sweden's economic policy. We have seen plenty of evidence of such talent in Sweden today, but found several deficiencies in its nurture and management.

A first-rate system of education, especially at the postgraduate level, is essential for producing not only the world-class stars of the future, but also the capable applied researchers who can help design good economic policy for the Swedish economy. And it is exactly at this crucial point, namely postgraduate training, that we found Swedish economics to be at its weakest, and most in need of drastic reform.

Economics has reached the point where a long and systematic process of training is needed to produce good researchers, writers and teachers. Undergraduate education should arouse interest in the subject, impart basic factual knowledge, and teach competence in analytical thinking. Postgraduate work builds on these foundations, and is the main source of an economist's professional training. It should consist of a core of microeconomics, macroeconomics and econometrics, followed by the study in depth of some specialized fields such as international trade, industrial organization, labour, and public 
finance, and finally a major piece of supervised but independent research culminating in a doctoral thesis.

The evidence we gathered from detailed studies carried out by Swedish economists, as well as from our own visits to many university departments and research institutes, showed serious problems at every stage of the process of educating an economist in Sweden.

The trouble starts at the undergraduate stage. The rigid structure of the first degree curriculum means that students begin their postgraduate education poorly prepared, especially lacking the mathematical and statistical background needed for first-year work in econometrics. Improved postgraduate teaching should begin with earlier identification of those undergraduates who are likely to go on to a doctorate in economics. They should be strongly advised to acquire the background knowledge that will be put to work in basic postgraduate courses. Recruitment of potential postgraduate students at an early stage would be more effective if likely candidates were presented with better teaching. There might be great value in having eminent professors do some undergraduate teaching, perhaps in special courses designed for potential postgraduate students.

Postgraduate students at the very beginning of their own careers, and without sufficient mastery in depth of the subject, bear the brunt of the education of undergraduates barely a year or two younger than themselves. Core postgraduate courses are often unsystematic and sporadically scheduled; courses in special fields are often unavailable. Research supervision is often inadequate. Doctorates take far too long to complete, and too many postgraduate students drop out somewhere along the way (see Chapter 4 above).

We should emphasize at the outset that in painting this bleak picture, we do not mean to blame the postgraduate students themselves or all the people who teach them. The source of the problem is in the structure of the system as a whole. Indeed, we found many individual teachers and students who are struggling heroically to overcome the obstacles they face. For them, as well as for those who have given up the difficult struggle and settled down to a quiet life within the system, the only real prospect for improvement is through systemic reform.

The structural problems can be placed in three rough categories: scale, incentives and tradition. We discuss these in turn.

\section{SCALE}

Sweden has a population of 8.5 million people; the United States has 
approximately 30 times as many, with a somewhat larger fraction enrolled in graduate school. The proportional equivalent of six Ph.D.granting departments in Sweden would be 180 in the United States. In fact fewer than one-third of that many American programmes amount to anything. This arithmetic suggests that Sweden conducts postgraduate education in economics with academic departments of inefficiently small scale. In fact the data collected in Chapter 4 show that postgraduate training in economics in Sweden is indeed a relatively small-scale enterprise. Over the twenty-year period from 1970 to 1989 , the number of Ph.D.s awarded was 219, averaging under 11 a year. During the period from 1983 to 1987, the average number of full-time equivalent Ph.D. students of economics in Sweden was only 165.

An average American economics department ranked in the top twenty admits twenty to twenty-five graduate students each year. The resident population is more than 100 . If we use these numbers as rough guidelines, it would seem that Sweden has room for one large or, for the sake of competition, two smaller postgraduate departments of economics. In fact it has six, and there is some talk of starting new ones.

The small scale hurts the process of education at almost every point. Perhaps our most shocking finding was that some departments (Umeå, Uppsala) cannot even offer the core courses in microeconomics, macroeconomics and econometrics every year. Postgraduate students have to spend two or even three years before they have the opportunity to complete their core education, or else they have to begin their study of specialized fields or even their research before acquiring adequate mastery of the basics. The situation is worse with regard to the special fields. Almost no department can offer courses in all the major fields every year; once every two or three years is the typical schedule. Even when offered, some fields in some departments enrol so few students that they are really no more than guided reading courses. Sometimes the students attend the lectures for the corresponding undergraduate courses, and supplement these with some additional reading of articles. It is also troubling that in some departments (Uppsala) almost a third (20 points out of 70 ) of the postgraduate course requirement can be met by taking undergraduate courses. In one department (Umeå), postgraduate training is essentially a self-study plan. Almost everywhere, the whole programme of postgraduate coursework is weak, takes too long, and constitutes an inadequate preparation for research.

Inadequate coursework at the advanced level hurts the students in 


\section{Views of the international evaluation committee}

their thesis research. They arrive at this stage without sufficient mastery of their field of interest to know where the best research prospects lie, and they have to spend another year or more searching for a thesis topic. The same weakness also hurts them in subsequent work, academic and non-academic. Indeed, at some of the research institutes (FIEF, IUI) which employ many economics postgraduates, we heard complaints that graduate programmes did not equip these employees with the necessary research skills. Econometrics was most often mentioned as a weak spot.

When the students proceed to the research phase, it is often difficult to match their interests with those of the local faculty members. Therefore the teachers have to supervise theses that are substantially outside their expertise. They seem to do the best they can, but the quality of the advice and the inspiration they can give must fall off as the students' research topics go farther from their own field of specialization.

A satisfactory departmental staff would certainly include one or two specialists in microeconomic theory and macroeconomic theory and at least one econometrician. In addition, for specialized teaching and for thesis-advising, most of the standard applied fields should be represented: labour economics, public finance, industrial organization, international trade, economic development. It is hard to see how a fully functioning postgraduate-level department could be constructed with fewer than eight professors, and more would be better. Only the Stockholm School of Economics approaches that size in Sweden today, and the staff there have responsibilities that go well beyond postgraduate teaching.

The problem of small numbers is often made worse by demographics. In some departments (Stockholm School of Economics and the Economics Department at Stockholm University) there are very few if any junior staff in a position to supervise research students. It is a sad but undeniable fact of academic life that the junior staff are the ones with the most enthusiasm and energy, qualities that are perhaps the most important in advisers of research students. The junior staff are also less likely to be burdened with administrative or outside professional duties, and therefore have more time to spend helping postgraduate students. They are felt by students to be more approachable.

Fellow postgraduate students are at least as important a source of advice and inspiration as are the members of staff. But a community of this kind needs a critical minimum size to constitute an active research group or a workshop. The right size in any one field is probably six to 
ten students at various stages of progress on their theses. When one or at most two students are engaged in research in a major area such as public finance or labour economics, they cannot benefit from the invaluable experience of such group interaction. Inadequate interaction with staff and fellow students is another factor that slows down progress on thesis research.

Finally, library facilities are poor in many of the smaller and newer departments. Their stocks of back issues of journals and older books are often incomplete. More generally, the need to spread limited resources over a large number of institutions must mean that each of them suffers a little. An efficient system of inter-library loans is at best a partial substitute, since it precludes browsing.

We conclude that Swedish postgraduate education in economics is conducted in too many departments, each of which is too small. It is not a practical possibility to turn the clock back and revert to a smaller number of departments. Tradition is too strong for that. But at least further decentralization should be resisted. It would be a very bad mistake to add new doctorate-granting departments. In Chapter 9 below, we will make some organizational recommendations designed to achieve economies of scale within the present university structure.

One way of adjusting to the inefficiently small size of the current departments would be for each to specialize partially in a couple of subfields of economics, making no attempt to provide course-work and thesis-advice across the board. That solution to the problem of scale would entail some migration of postgraduate students to other universities, either at the beginning of postgraduate work, or after the basic courses had been completed. At either stage, a postgraduate student interested in labour economics, for instance, and currently enrolled in a department not offering that specialty, would have to shift to a department that did so.

Although we have no precise count, our strong impression confirmed by everyone - is that most Swedish postgraduate students have stayed at the university of their first degree and resist the idea of moving to another. The reasons for this immobility include strong attachment to the home area, the difficulty of finding adequate and inexpensive housing in a new place (especially in the Stockholm area, of course), and the fact that many postgraduate students have working partners who would be forced to change to an inferior job. This last problem is compounded by the long duration of so many postgraduate-student careers; after some years, the working spouse may have achieved considerable seniority in his or her job. Any practical 


\section{Views of the international evaluation committee}

solution to the scale problem must take this immobility into account and somehow circumvent it.

\section{INCENTIVES}

For a system to function well, its individual members should have the right incentives. This is a fundamental insight of economics, but it seems to be ignored in much of Swedish postgraduate education in economics. In fact the system is riddled with perverse incentives, and places obstacles in the path of the typical postgraduate student at almost every stage.

At the broadest level there is insufficient material incentive to embark upon a postgraduate programme in economics, and to continue in a research or teaching career. The immediate financial rewards in industry and banking are far more attractive to fresh graduates than the prospect of several years as a doctoral student. For those who do choose postgraduate study, there is the continual temptation to drop out along the way, maybe with a licentiate, maybe not. This is not a problem peculiar to Sweden, and there is probably little that can be done about it. But we did find it surprising that even the finance programme at the Stockholm School of Economics had difficulty in attracting students of high enough quality and in sufficient numbers. In American business schools such programmes have been very popular because of the lucrative careers that await their graduates in financial institutions or consulting firms.

Fresh postgraduate students immediately face the problem of financing the first year or two of their studies. Very few fellowships free of obligations are available at this stage. Most students earn their way by teaching undergraduates, sometimes in very large classes. The work is quite demanding. We heard figures (Uppsala) as high as 200 hours a year - almost twice the teaching that is notionally required of professors, and almost three or four times what many professors teach in reality. The problem is compounded by the inexperience of these graduates. They themselves studied only a year or two ago the subjects they are now supposed to teach. Therefore their mastery of the material is less than perfect, and they must spend a lot of time and effort on their teaching preparation. All this interferes with their ability to learn a lot of new and difficult material in their own postgraduate core courses. Their education gets off to a slow and weak start, when a fast and confident start would do a lot for their momentum as well as their morale.

Loans are an alternative source of finance for the first year or two 
year or two of postgraduate work. Different departments seem to have different 'cultures' in this respect: in some (Gothenburg) loans are the most common solution, in others (Stockholm) it is mostly teaching. Loans might seem a better idea, given the difficulties of teaching mentioned above, but they raise their own problems later. Careers with high financial remuneration become that much more attractive, making it harder to recruit high-quality economists to careers in universities, research institutes and public service.

In some departments (of which the Stockholm School of Economics and Gothenburg University are the outstanding examples), staff members have research projects funded by external grants, and can employ new postgraduate students as research assistants. This is often a better way of financing these students. The work is generally less time-consuming than teaching, and there is the added advantage of an early initiation into research and personal acquaintance with a member of staff. But such positions are not uniformly available, and their duties are not standardized. As a general proposition, it is better for first- or second-year graduate students to serve as research assistants than as classroom teachers. If that is not possible, we would urge that the duties of first- and second-year teachers be limited to grading examinations rather than classroom teaching. It would be a very good idea to create externally financed stipends for students whose reciprocal obligation would be research rather than teaching. Besides improving education generally, this device could justify itself by permitting graduate schools to produce better potential civil servants and better trained economists for the private sector. This would be especially useful if there should be a diminished demand for academic research and researchers.

Some might argue that if core courses are not available every year in any case, a system that requires students to earn money teaching and slows their progress through the core is not so bad. But we think that the two wrongs don't make a right.

After one or two years, many students are able to obtain scholarships (utbildningsbidrag or doktorandtjänst) with no obligations or at least only modest ones. Now the nature of the problem changes dramatically. These scholarships are usually available for four years, and pay about SEK 12,000 a month. Upon completion of the doctoral thesis, the fresh Ph.D. would command a salary of SEK 14,000-16,000 in a university. The few who go to a research institute would get SEK 20,000 . If he or she had financed the first year or two of study by borrowing, then repayment of the loan must commence upon completion of the Ph.D. When the high rate of income tax is taken into 


\section{Views of the international evaluation committee}

account, it becomes evident that there is no financial incentive to complete the Ph.D. promptly.

By way of contrast, when an American economics student earns the Ph.D. and becomes an assistant professor, his/her gross income may rise by as much as 300 per cent, and net income by over 200 per cent. Without wishing to justify this as the right amount of incentive to complete the thesis promptly, we do want to suggest that the Swedish system almost certainly errs too far in the other direction.

Some students (Stockholm School of Economics) told us that they viewed a research studentship as a semi-permanent career, not as a short phase of training to be completed in the minimum necessary time. After their scholarships expire, they can return to a phase of heavy undergraduate teaching while remaining registered as postgraduate students. Given all the other problems that slow down the student's progress through the programme, the perverse financial incentive seems especially unfortunate. The average age of a new doctor in economics is 35.6 years; and the average length of a postgraduate student career from first enrolment to completion of thesis is about eight years in elapsed time (and about six years of actual enrolment). Both figures are too high.

Overall figures for recent doctorates in economics in the United States would not be radically different from these. But the total number of Ph.D.s in economics granted in the States is about fifty times that in Sweden. In the top twenty universities the average time to a degree is certainly considerably shorter.

Let us turn to the structure of incentives for a fresh Ph.D. embarking on an academic career. As mentioned above, the salaries are low, and not much better than the postgraduate scholarships. In addition, the new doctors lose any subsidized housing they enjoyed as postgraduate students, and must start repaying any debts they had acquired in the first year or two of studies. Add the financial needs of young families, and the pressure to supplement their earnings by consulting and popular writing becomes too great to resist. Teaching and research suffer. Of course much the same is true in other countries.

There are also non-financial problems facing the new doctor. The career track splits into two. The lecturers have very high teaching loads: $\mathbf{4 0 0}$ hours of lectures each academic year. This is two or even three times the amount that is typical in good American departments, and about twice that in good British departments. Some Swedish departments (Lund, Umeå) have made special arrangements reducing the teaching load of lecturers to 300 hours, but even that is high. Such 
a load would leave little time for research, even in an ongoing mode where lecturers teach the same course from one year to the next and need little new preparation. For fresh Ph.D.s who are planning their lectures for the first time, these teaching duties shut out research altogether. And that could not happen at a worse time. Fresh Ph.D.s are often in a very mixed state of mind. On the one hand, their enthusiasm for the subject, and for research generally, is very high. On the other, they have just completed a major piece of research - the thesis - and the temptation to relax for a while is also great. The teaching requirements are a perverse incentive that tip the balance towards the latter, and the danger is that some victims will never recover to become productive researchers again.

The other career track goes to the other extreme. Some forskarassistent positions are available for a limited time and involve almost no teaching duties. While these allow the holders to maintain the momentum of their thesis research, they delay their assimilation into the teaching half of the department's intellectual life. To the extent that the holders of these positions find it easier to get research done and win professorships, the habit of low teaching spreads to the professorial level. In most departments we were told that the official teaching obligation of a professor was 120 hours for the academic year, but the reality was somewhat less. Exact figures were not forthcoming, and we suspect that in some departments the teaching is unevenly distributed, and some senior professors actually teach very little.

This brings us to the mechanism by which professorships are created. In recent years this has been a political decision. Chairs are established in specific departments and in specific subspecialties (e.g. the Umeå chair in recreational economics) as part of the parliamentary process of educational budgeting. This is done without any consideration as to whether enough additional students of adequate ability and motivation will be forthcoming for these professors to teach. There is certainly no concomitant obligation on the favoured department to recruit more students. The result is a severe misallocation of resources across departments and across various academic career positions. Some professors in some departments enjoy near-sinecures, while lecturers elsewhere toil long hours teaching and cannot find time for research. In some fields it becomes easy to get a chair, while others who are far more able researchers and teachers but are outside these politically favoured specialties, must wait long periods for a position to become available.

Since we are recommending that professors spend more time 


\section{Views of the international evaluation committee}

teaching than they do now, there is a case for an institutional innovation that would allow productive scholars to undertake periods of intensive research activity. This could be accomplished by establishing a number of temporary research professorships that allow the incumbent a specified period - three years would be about right - free of teaching responsibility, and provide some limited research funds to be used during the same period. Ordinary professors could apply for these temporary chairs on the basis of proved productivity in scholarly research and a proposal to be carried out during incumbency. We are told that some professors more or less abandon research after having achieved a chair. Perhaps these temporary professorships would provide an incentive for continued scholarly research.

\section{TRADITION}

A Ph.D. thesis is intended to serve as an apprenticeship in research. Therefore its substance and format should follow the professional practice in the subject. In economics most research results are communicated to the profession in the form of journal articles. A century ago the main mode of publication was the book or the monograph. The transition to articles became noticeable after the Second World War, and is essentially complete now. Doctoral theses in the United States and in many other countries have quite properly followed this change, and consist of a number of essays that do not even have to be tied together by a common theme. In Sweden, too many theses continue to be written in the monograph or magnum opus form, despite an attempt made twenty years ago to change the system. Here we examine some of the reasons for this persistence, and comment on some of its consequences.

Perhaps the main reason for the persistence of the monograph form is the sheer weight of tradition. A proper thesis is supposed to be a monograph; a collection of essays is somehow regarded as inferior. Even now, a monographic thesis counts for more in a job application and is perceived as doing so. Second, some advisers emphasize the need for a single theme to the thesis; this channels their students' thinking into the monograph mode. Third, students who are thinking of going into non-university and non-research careers, say in banking or government, see the thesis as the only creative research they will do in their lifetime, and want it to make a big contribution. Finally, there is an explicit or implicit condition (see the discussion on page 86) that the articles in an essay-form thesis should already be published in journals, whereas a monograph needs to be published only in an in- 
house series, protected from a tough refereeing process. Even if not enforced, this predisposes students to the old form.

The reliance on the monograph form delays the research student at almost every phase. The expectation that the thesis should constitute a major and memorable contribution leads students to spend a lot of time waiting for a sufficiently big idea. All along the way, the need to tie all research to the single theme of the monograph also slows progress. An article format with diversity of theme would allow the novice researcher to make a simple beginning by developing modest previous efforts embodied in term-papers or critical reviews prepared for the specialized field courses. What is more, any worthwhile idea that occurs to the student can be developed into an article and form a part of the thesis, without any need to worry about its relation to a grand theme.

Perhaps the monograph format would redeem itself if its results were sufficiently big and impressive. There are some famous examples, notably Erik Dahmén's two-volume, 700-page thesis published in 1950. If many were of that calibre, the form could be defended. But that does not seem to be the case. Many theses acquire the bulk appropriate for a monograph by including lengthy literature surveys that do not contribute anything beyond what is available in various recent handbooks or even postgraduate textbooks on the subject. The original contributions could just as easily have been written in the form of collections of short articles.

There are some indications that the grip of tradition is slowly loosening. At least one department (Uppsala) seems to have made a successful transition to regarding a collection of articles as the normal form for the thesis. In some other departments (Gothenburg) the mix has improved to about 50:50. Even now the norm appears to be four published essays; three, certified by the examiner to be of 'publishable quality', would probably be enough. Insistence on actual publication should be resisted.

Another aspect of tradition is a parochialism in the selection of postgraduate programmes, and of academic careers. It is normal for an undergraduate at Lund, say, to continue as a postgraduate student in the same department, and carry on as a lecturer or a forskarassistent there. Moving to another university is very exceptional. It is only at the professorial level that the open competition produces some mobility. We regard this state of affairs with considerable alarm. Exposure to fresh ways of thinking is extremely important for the healthy development of a creative mind, and the dangers of intellectual inbreeding are most serious. At a more practical level, it becomes 


\section{Views of the international evaluation committee}

harder to match the interests of research students with the special skills of the faculty. A problem that is already serious because of the small scale of the system is made all the harder by the lack of mobility.

\section{CONCLUSIONS}

The main conclusions of our analysis in this chapter are:

1 Postgraduate teaching of economics in Sweden is conducted in departments that are too small for efficient functioning. One result is that it takes too long to complete a doctorate. The inadequate preparation of beginning postgraduate students - especially in mathematics and statistics - is another contributory factor.

2 This problem is exacerbated by the system for funding doctoral students. The students do too much teaching at the wrong times. Moreover, financial incentives work against quick completion of postgraduate study.

3 Yet another source of delay is an out-of-date approach to the doctoral thesis. Another and more determined attempt should be made to establish the acceptability of a thesis consisting of several, possibly unrelated, essays. It should be kept firmly in mind that the thesis should be the start of a research career. not its culmination. 


\title{
9 Recommendations
}

\author{
Avinash K. Dixit, Seppo Honkapohja and \\ Robert M. Solow
}

Our investigation of economics in Sweden has identified several strengths and weaknesses. In this chapter we bring together the various strands, and suggest some strategies that can build on the strengths and remedy the weaknesses. We begin with a brief overview.

\section{SUMMARY OF GOOD AND BAD FEATURES OF THE SYSTEM}

\section{History of excellence}

Probably the strongest feature of economics in Sweden is its long tradition of excellence unparalleled in any other small country. The Wicksell-Cassel group and the Stockholm School made world-class creative advances in important areas of economics. The emergence of such stellar groups may be largely a matter of chance, but it requires a core of some quality and strength. This exists now; there are identifiable groups making significant contributions to areas such as international economics and labour economics. But there are other areas and institutes that fare less well than they could, or should. Econometrics is a relatively neglected area in many university departments. And the large volume of routine studies of less developed countries does not seem to be a good way of using valuable Swedish professional talent.

\section{Internationalization}

The leading researchers in Sweden are well integrated into the international profession. The IIES has regular contacts with Europe and the United States, including lengthy visits by foreigners to the IIES and vice versa. Some other university departments and institutes have similar arrangements on a more ad hoc basis or with particular individuals. The internationalization also extends to publication. On a 


\section{Views of the international evaluation committee}

per capita basis, Sweden contributes to leading international journals in economics four times as many articles as Germany, and nearly five times as many as France (cf. pages 107-16 above). But the distribution of these publications among individuals and institutions is very unequal. Almost all university departments and research institutes are aware of the importance of participation in the worldwide profession, but the record of actual success is very mixed. Some departments are too isolated, and this has hurt the direction and the quality of their research.

\section{Resources}

The funding of postgraduate teaching and research in economics in the 1980 s is at best a somewhat worrying tale. Relative to GNP, the resources available to economics have declined slightly. The data in table 3.2 also show a much more pronounced decline relative to that for the social sciences as a whole - from 8.1 per cent to 6.7 per cent - but this is probably due to the addition of new areas of research to the social science faculties rather than any decline in support for economics.

Tight funding leads to low and compressed salary structures, which reduce the financial incentives to join the profession and to do well in it. Facilities for research and teaching are also affected: space is tight, some libraries are inadequate, and while computing hardware does not seem in short supply, software and advice are usually scarce.

A substantial proportion of funding comes from external (nonfaculty) grants. Researchers therefore have to channel their efforts into the pursuit of such grants, and away from scholarly academic research. Likewise, the additional source of funding for graduate students is welcome, but the work entailed can slow down their progress towards a thesis.

\section{Scale}

The country can support one or at most two departments close to an efficient scale, but it actually has six, and there is some talk of adding new ones. We argued in Chapters 7 and 8 that the quality of research and of postgraduate programmes suffers a great deal because of the inefficiently small scale. Research in teams is hard to mount, and the stimulation of interaction with colleagues is reduced. Teaching staff in small departments have to spend a larger proportion of their time in administration. In postgraduate training, advanced field courses and even basic theory and econometrics courses cannot be offered with 
regularity, teachers with the appropriate expertise to supervise specialized dissertations are not available, and learning by interacting with fellow students is minimized.

\section{Incentives}

In our judgement, the incentives to complete postgraduate programmes promptly are very inadequate. In fact several obstacles are so placed as to slow down even the most determined students. Many departments require heavy undergraduate teaching duties of their beginner postgraduate students. Scholarships are available for four years, but they often start as late as the third year of study, and the difference between these scholarships and the salaries for first positions on the staff are small, so the financial reward for early completion of the thesis is minimal. Even in the American system where the incentives are stronger, the time taken for a doctorate degree has been rising, and the rise has caused concern. In Sweden the lack of incentives exacerbates the problem.

\section{Tradition}

Tradition has its bad aspects. Its weight is most crushingly felt in the continued popularity of the massive monograph-type thesis. Articlestyle theses would be more in keeping with the current format of research publication in economics, and a move in this direction was planned. But it seems to have been stymied by tradition, and by the excessive burden of an explicit or implicit requirement that the articles be previously published in journals. Only one or two departments have adopted the article format as the norm. Another and perhaps even more destructive aspect is the lack of mobility between universities except at the professorial level. The consequent inbreeding can only lead to stagnation. We recognize that mobility is genuinely difficult when most academics have working partners, and housing can be difficult to find and expensive especially in Stockholm. But that makes it all the more important to investigate alternatives to full mobility, such as short-term exchanges and workshops, particularly at the stage of postgraduate education when many work habits are formed.

\section{Career tracks}

The split between teaching and research at the beginning of academic careers is very unfortunate. The lecturers have such heavy teaching 


\section{Views of the international evaluation committee}

loads that many of them can never resume successful research. Forskarassistent positions are few in number and their holders do not have the stimulation from teaching and research supervision that is so important for continued freshness in research. Forskarassistents can generally do more research and are more likely to become professors; perhaps that is why a tendency to neglect teaching gets built into a significant proportion of the professorial corps.

\section{RECOMMENDATIONS CONCERNING ORGANIZATION OF RESEARCH}

We argued in Chapter 7 that Sweden is producing research of good quality in many areas of economics. But the overall level of ambition of the research community is lower than it should be; some areas like econometrics are relatively neglected, and links between different universities and institutes are generally weak. We offer several suggestions that could help improve matters.

\section{Increasing competition in research}

The most successful single centre of economics research in Sweden is undoubtedly the IIES. This Institute's permanent staff has a better record of publication in major international journals than the rest of the Swedish profession combined. Perhaps because of this it has increased its faculty grants and has also succeeded in attracting substantial external funds. This has led members of some departments elsewhere in Sweden to recommend the setting up a second research institute that would have a different and complementary focus, for example domestic rather than international.

The main argument for this is increased competition. Such an institute could keep IIES on its toes by offering the best talent an alternative home. The general aim of increasing competition is desirable; the question is the appropriate way of achieving this aim.

Any university or department can establish an administrative structure, call it an Institute, and attempt to raise funds for research projects and short-term positions. If the researchers demonstrate success in their initial projects and acquire reputations, they will find it easier to attract more funds committed for longer periods. In time, such a collection of people and projects could evolve into a real major Institute that could compete successfully with IIES. Indeed, the IIES itself evolved gradually by just such a route over a decade or more.

We believe that any competition for IIES should emerge organically 
and entrepreneurially in this way, and not by the centrally directed creation of a shell called the Institute for Domestic Economic Studies (IDES), which starts out with any significant medium- or long-term commitment of positions or funds. The track record of such 'centrally directed competitors' is not very good; think how many localities try to set up high-tech research and manufacturing zones hoping to become the next Silicon Valley, and how few succeed. The prospects of success of an institute brought into being in this way would be very uncertain at best. Moreover, in our current reality of limited funding for higher education and research in general, and economics in particular, an IDES would inevitably divert some funding from IIES. That would risk the continued success of the one endeavour in economics where Sweden is currently a leader in world research. In short, we recommend that Swedish economics should 'Beware the IDES.'

\section{Research groups}

We therefore suggest a different approach which can achieve some of the benefits of diversity and competition. Our approach has some added benefits in the Swedish context, for example in reducing some of the harmful effects of isolation and inbreeding in departments. It can also help identify, with a smaller initial commitment, high-quality researchers who might evolve into a more permanent and larger-scale institute.

The idea is a framework of research groups to carry out specified programmes of research, each unified by its topic or theme but crossing departmental lines. The scope of each group would be narrower than that of major areas of economics, but broader than that of a typical research project. Examples of coverage might be 'contract theory and its applications' or 'multinational corporations'. Activities covered by a group would include:

1 provision of research resources like computing, and some data collection for specific purposes;

2 management of databases and ensuring their availability for use by the research community;

3 support of postdoctoral research but not postgraduate fellowships; and

4 organization of workshops and publication of research output.

A research group programme would be announced as an initiative by the HSFR, or other similar grant-giving bodies. Economists with common research interests but located at different universities and 


\section{Views of the international evaluation committee}

institutes would get together, perhaps at a small initial planning conference, to draw up a programme of work and apply for a grant. A typical group would consist of five to ten active workers and perhaps an equal number regularly but peripherally involved in activities such as workshops. Their typical programme would last for four or five years. The grant would be renewable, but on the basis of a new application with a new plan for future research.

IIES staff should have the opportunity to participate in these groups. But the Institute as such should not have any presumption of priority based on its general quality; rather, each programme should be judged on its own merits. Qualified researchers from regional colleges would be especially welcome members; this would be an efficient way of reducing their isolation from the research community. The groups would also be encouraged to collaborate with similar research efforts in other countries, for example activities in other Nordic countries, and the programmes of the Centre for Economic Policy Research in London and the National Bureau of Economic Research in the United States.

The activities of each group would be coordinated from the home institution(s) of its leading member(s). Individuals could also bring their other grants and research activities under the auspices of the group. But there would have to be significant infusion of net new money to induce people to do this. The scheme should promote scholarly academic research, both theoretical and empirical. The groups should not be concerned with routine studies, consulting and policy advice; those activities are valuable but are better financed from other sources.

\section{Links between university departments and research institutes}

While research institutes like IUI and FIEF have a generally good track record in recruitment as well as performance, this may be partly due to the corresponding failure of some university departments. We believe that both types of institutions will benefit by promoting better links between them. The staff in university departments will have better access to data and other resources of the research institutes, and the institute staff will have the opportunity continually to refresh their interest in the subject by interacting with students and more scholarly researchers. Such links exist on an ad personam basis, but we believe they should be more organized and more widely available. The research groups we suggested above would serve to bring together interested researchers from the two institutions. Universities could 
also benefit by inviting suitable members of research institutes to be 'guest teachers', not necessarily with any regular staff positions or titles.

\section{Career tracks}

We believe that the bifurcation of post-Ph.D. careers into heavy teaching (lecturer) and very light teaching (forskarassistent) tracks is very unfortunate. A balance of teaching and research would be in the interests of all. The two positions should be blended into a single career line, like lectureships in Britain or assistant professorships in the United States, with teaching loads of under 200 hours and the expectation that the individual concerned will maintain a reasonable quality of research and will publish its results. The younger staff should also be encouraged to play active roles in the supervision of postgraduate students' research.

The transition to a single career track requires careful attention to the situation of the existing lecturers. Those who wish to continue in their teaching positions should be allowed to do so. Those who wish to switch to the new track should be given assistance to develop a plan of research.

The proposal also implies a suggestion for modifying the method by which funds for staff salaries are allocated. The faculty grants for the two positions now come from quite distinct sources (cf. pages 49-50 above). Unification of the tracks entails unification of the salary sources too.

At the upper end of the career track, professors are thought to have inadequate incentives to continue high-quality scholarly research. A possible remedy is to establish special research chairs, with higher salaries and greater distinction, and award them to individuals for limited periods of time. We are unsure of what this will accomplish. If the reason for the poor research performance of some professors is that they are overburdened by internal (teaching and administrative) duties, then the chairs may offer them the time and the freedom to return to quality scholarly research. But if the problem is the lure of the much larger sums of money and public recognition that are available from consulting, journalism, etc., we do not think these individuals will alter their ways for the sake of special chairs. The chairs will then have no incentive role; they will be mere ex post rewards to people who would have done the high-quality research anyway because they had their own drive and motivation.

Another problem at the professorial level is the growing tendency to 
establish chairs in narrowly specialized areas. A chair entails a commitment for the thirty or forty years during which the first incumbent holds it, and perhaps much longer. Narrowly specialized areas have an immediate importance or fascination, but their lasting significance is often uncertain. For example, one can be fairly sure that a general area such as industrial organization will continue to occupy a central role in economics for a long time, but the future of a specific industry such as textiles is much less clear. In our judgement, this says that the case for a chair of textile economics is much weaker than that for a chair of industrial organization.

There is of course a legitimate case for supporting topics that are currently important, economically or politically. But we believe that such special fields are more effectively cultivated by allocating special research funds to launch special research projects in those areas. Such initiatives will have better leverage and elicit more response from more economists than the establishment of a chair is likely to do. This approach will also preserve the granting body's or the government's flexibility: project funding has a much more limited commitment, and can be redirected every three or five years in response to changing priorities. The approach would also mesh naturally with our recommendation on research groups.

Last, but very important, is the problem of inbreeding. We recommend that departments abandon tradition, and start actively recruiting postgraduate students from among the recipients of the first degree (grundexamen) at other universities, and junior staff from among the new doctors at other universities. The competition would be good in itself, and cross-recruiting would make it easier to build viable groups of specialists in small departments.

\section{Balance between scholarly research and routine studies}

Almost every country has to supply its own economic practitioners people who serve on government committees, consult for businesses, and write for newspapers and magazines. This is an almost nontradeable service. This work belongs to the category we called 'routine studies' in Chapter 7: it uses known methods and data for particular problems of local interest. By contrast, scholarly research, both theoretical and empirical, requires significant creativity and innovation in data, concept or method; such work is more international in scope.

Many small countries are tempted to leave scholarly research to the rest of the world, and concentrate on their own local routine studies. 
We see similar tendencies in Sweden. For example, in Chapter 2, Lars Jonung emphasized the contributions of Swedish professors to Swedish economic policy debates, of a kind that we have called 'routine studies'. We would like to register an opposing view, and stress the importance of high-quality scholarly research. In the CasselWicksell and the Stockholm School decades, Sweden had a spectacular success in producing scholarly research at the frontier of economics and exporting it to the world. Wold had a similar but more isolated success in econometrics. There is now a small but significant group of researchers, most of them at the IIES, whose members are producing first-rate scholarly research. We believe Sweden should continue to support their activities. They bring the country international scholarly recognition. A more immediate benefit is that routine studies in Sweden are improved by the presence of high-quality scholarly researchers. They interact with the frontier of the subject on the one hand and with those Swedish economists who are mostly engaged in routine work on the other. Thus they can serve as important intermediaries between new ideas and their ultimate users.

Consulting, journalism, etc. bring immediate rewards in the form of income and public recognition. Scholarly research, both theoretical and empirical, is a less well paid and less visible activity. Therefore in our judgement it is all the more important for universities, research institutes, and fund-granting authorities for research and teaching to ensure that scholarly work is properly encouraged and supported.

Jonung agrees that Swedish economists' strong engagement in practical affairs has had some detrimental effect. As he says on page 48, it has created 'a sceptical attitude towards what Erik Lundberg called "Alpine economics", by which he meant theoretical economics with little or no empirical relevance'. The Alpine heights of the subject may be cold and forbidding places, but unless they are well cared for, the routine workers on the lower slopes and in the valleys are liable to get buried by the avalanches that occur whenever there is a fundamental conceptual revolution in the subject.

A recent example will make the point more forcefully. In the last two decades, the major conceptual revolutions in our subject have come from information economics and game theory. These ideas have totally altered the way we think about firms, markets, contracts and competition. These revolutions were made by people inhabiting the Alpine heights: Stiglitz, Mirrlees, Spence and the like. The routine workers in the valleys at one time regarded much of this work as having very little practical relevance. In Sweden, were it not for the active intermediation of people like Henrik Horn and Jörgen Weibull, 
who assimilated the revolutions in their own research and teaching, the emerging practitioners would be in a sorry state of isolation, buried in the old snow of the neo-classical version of competitive equilibrium.

\section{RECOMMENDATIONS CONCERNING POSTGRADUATE TRAINING}

Our discussion of postgraduate education in Chapter 8 identified several serious deficiences. We believe that the system requires some drastic reforms. These should not consist of blind imitations of any other system. In particular, the quality of postgraduate training that is offered in the top ten American economics departments is probably the best anywhere, but the size, the resource base, and the career structure of the American system is so different that Sweden should not attempt to import it wholesale. There are some features that could be usefully imitated, but these should be combined with good ideas from other Nordic countries, the Netherlands, Israel, and so on. Finally, any proposed changes should be examined for their feasibility in the overall Swedish social and political environment, although it would be a mistake to make this into too rigid a constraint and to be timid in offering alternatives.

With these points in mind, we have examined several ideas of our own, and others suggested to us by Swedish teachers as well as students during our travels around the country. In what follows, we summarize those that seemed the most promising and important.

\section{Size and numbers}

By any reasonable standard of a minimum efficient scale, there are too many postgraduate programmes of economics in Sweden. Ideally, there should be no more than two. However, we recognize the practical impossibility of shutting down any of the existing departments. We are willing to find solutions to the pressing problems within the restriction imposed by the continuing existence of the current programmes. But it is essential that matters are not made worse by the establishment of any new departments, or of any new postgraduate programmes in universities or colleges that now offer economics only at the undergraduate level. 


\section{Organization of first-year courses}

We believe that all university departments should provide first-year postgraduate courses in microeconomics, macroeconomics and econometrics every year. This should be regarded as an important part of the teaching duties of the professorial corps, and its realization at a sufficiently high standard should become an important mark of the quality of a department.

All university departments should also provide at least one regular workshop for thesis-writing students. Some may have just one workshop that spans different fields. But all should be encouraged to develop specialities or niches that, when they become generally known, will attract students from other universities if the problem of immobility can be overcome.

\section{A national system of intensive second-year courses}

We recognize that all departments cannot offer courses of adequate quality in all the specialized parts or fields of economics that their second-year students wish to study. But almost all important fields are well covered somewhere in the Swedish system. Therefore we propose a major reorganization of the way such fields are taught.

The idea is to establish a nationwide system of specialized courses, to which each department contributes according to its comparative advantage. A number of similar plans exist or are being developed in other small European countries. In the Netherlands such courses are offered every Friday at a central location, and students from universities all over can easily commute to attend them. Distances in Sweden are much larger, and students from Uppsala already find it somewhat difficult to attend courses in Stockholm without spending most of the day to go to just one lecture. Therefore nationwide courses in Sweden will have to be residential. It then becomes necessary to make them short and intensive, so the students do not have to spend long periods away from home. This makes the format closer to that of intensive courses in Norway, Finland, Denmark and the Netherlands. These considerations govern the format we suggest below.

In each special field and every year, there should typically be two intensive courses, each lasting for three weeks. These would be held at different departments which possessed the appropriate expertise. Students from all over Sweden would attend them. The courses would constitute the bulk of the training in that field for the year, to be supplemented by some assigned general reading done in each student's 


\section{Views of the international evaluation committee}

home university. The courses might occasionally be taught by foreign visitors, but we expect that the teachers would normally be Swedish. This teaching would constitute a part of their teaching obligation to their home department. The students' travel and accommodation expenses would be covered from a central fund set up for this purpose, or alternatively channelled through the students' 'home' departments.

A small joint committee of the departments and some research institutes would determine the programme - topics, teachers, places and dates - of these courses each year. This should be done with sufficient lead time to allow students to plan their studies and lives properly. By the middle of one academic year, the programme for the following year should be firmly in place.

We choose International Economics to illustrate how such a programme might work. The two intensive courses would be 'Theory of trade and commercial policy' and 'Exchange rates, balance of payments and macroeconomic policies'. If student and departmental interests justify it, there might be an occasional additional course, for example 'International policy conflict and coordination'. Each of these courses would last three weeks, and be organized along the following lines. Each day's programme would be as follows:

$\begin{aligned} 8.30-10.00 & \text { Lecture I } \\ 10.30-12.00 & \text { Lecture II } \\ 14.30-16.30 & \text { Workshop }\end{aligned}$

This would yield 45 hours of lectures, which is almost exactly a full semester's load in an American graduate course. For each day of the first two weeks the workshop would be organized around a critical discussion of a research article in the relevant literature. In the third week the students would start work on small research papers of their own and try out the ideas in the workshop.

There would be two teachers, each of whom would give one lecture each day, and attend the other's lecture and the workshop. Each would be given about 60 hours of teaching credit in his or her own department for this participation. We believe that such a system will greatly improve the teaching of special fields, and will have a number of additional advantages. The improvement in teaching will come from the availability of truly expert teachers, and from the better utilization of scale economies. Incidentally, the IIES, which is sometimes criticized for not doing enough teaching, could make a very valuable contribution by participating in the training of postgraduate students from all over Sweden in the areas of its expertise, particularly international economics. labour economics and macroeconomics. 
The by-product advantages are numerous. First, the contact with students from other universities will prove very valuable to all participants in widening their horizons, and establishing research networks that can last a long time. This will do something to alleviate the stagnation caused by inbreeding. Second, the workshop component of the programme can yield research topics and give the students an early start on their theses. Third, the national courses will indirectly raise the standard of the first-year core teaching in the separate departments. The need to prepare their students to the point where they can benefit from the specialized courses, and the knowledge that the standard of their students will be measured against that of students from other departments, will act as a salutary competitive disciplining device for the teachers of macro, micro and econometrics courses. Finally, such courses will prove to be particularly useful in the few important fields where most departments are weak, most notably Econometric Method.

Most other Nordic and European countries have programmes of intensive courses, and offer scope for collaboration at an international level. But we suspect that such wider arrangements are best fitted for advanced research level courses; most of the second-year courses we have suggested can be run at an efficient scale for Sweden alone. Provision of advanced overviews of 'hot' topics, both in economics and in econometrics, could be usefully done at the Nordic level. Such short courses would be very helpful for advanced postgraduate students and junior teaching staff.

\section{Fellowships for study overseas}

Much can be gained from improvements in graduate training within Sweden, but a case remains for sending a small number of particularly promising students each year to the best programmes abroad. We stress that they should follow the full doctoral programme there, and not just visit for a year. We expect at most two or three students a year to qualify for admission to a top-ten programme in the United States or an equivalent programme in Europe. Some years perhaps no students will qualify.

We suggest a systemwide competition for a few fellowships to support these students. Potential candidates should be identified in the last year of their undergraduate course, or the first year of their postgraduate studies in Sweden, and should be nominated by their departments for a process of nationwide selection. There should be an aura of prestige about these awards, like the Kennedy Scholarships in 


\section{Views of the international evaluation committee}

Britain or the Fulbright awards in the United States, to encourage the best students to seek them.

Some of the prestige would also reflect on the Swedish departments that 'export' these students. But the faculty might still be reluctant to lose its best students in this way. As an incentive or a sweetener we suggest that the exporting department be given a sum equal to the fellowship awarded to the departing student. The department could use this for augmenting the support of its own postgraduate students, thus improving its attractiveness in the country. A rough estimate of the cost of such a scheme can be made. Each student going to the United States will require a stipend of about $\$ 12,000$ each year. We expect that students of top-ten calibre who have their own stipend support can easily obtain tuition waivers from American universities, so little or no provision need be made on that account. Two students each year for four years means a steady-state population of eight. This will cost about $\$ 100,000$, or SEK 600,000 . Matching grants to the exporting departments will double the cost to SEK 1.2 million per year. In our judgement this relatively modest expenditure will yield very high returns.

\section{Financing of postgraduate studies within Sweden}

It is essential that the burden of teaching or borrowing to finance the first year or two of study be eased. Therefore the doktorandtjannst awards should commence at the beginning of a student's postgraduate programme, and teaching should be forbidden until students have completed their coursework. Where employment of first- and secondyear students is unavoidable to ensure their financial support, grading undergraduate examinations seems a preferable alternative. From all postgraduate students who have completed their course work and are engaged on thesis research, a modest amount of teaching, say six hours a week, should be required. The more mature students will be better teachers, and some experience of teaching will prove valuable in the future career of all postgraduate students. Even this teaching should generally be limited to small classes supplementing regular lectures by the faculty staff; responsibility for major undergraduate lectures will cause serious interruptions in a postgraduate student's thesis research.

Of course the change involves some risk: some students will receive the awards for a year or two and then prove to be insufficiently qualified for, or interested in, completing the programme. But we believe this risk is worth taking because of the large expected gain it 
will bring in speeding up and improving the education of the vast majority of the students.

At the other end, since the financial incentives to complete the programme are so weak, it is essential that non-financial incentives or penalties should be employed with greater force to dissuade the 'eternal postgraduate student'. Mere exhortation, and the creation of a culture in which there is some shame to being a seventh- or eighth-year postgraduate student, can go some way towards this goal. More formally, the total amount of time for which a postgraduate student can stay in the programme should be clearly limited. Scholarships should not be available beyond the fifth year of study. Opportunities to earn money beyond this time by doing undergraduate teaching should also be limited. Students who take five or more years on their thesis research should be made to take the special field course examinations again to prove that they are still up to date in their subject.

\section{The nature of the thesis}

Another effort should be made to adopt the article-collection format for the Ph.D. thesis, and this time there should be greater determination to make it succeed. It should be made clear that the articles that constitute a thesis need not be tied together by a strong common theme. The requirement of prior journal publication of the articles should be abandoned; instead the examiners should be asked to provide assurances about publishability. Some may fear a lowering of standards if this is done. But the system of using external examiners (opponents) acts as a guard against abuse. Also, the monograph theses are not now subject to prior external refereeing before publication, so it is hard to see why the article format should be subjected to a higher standard.

Many students are deterred from choosing an article format by the belief that the monograph format is favoured when candidates are evaluated for jobs, whether in university departments, research institutes, or in non-academic careers in banking, business, or government. To the extent that such practices really exist, they should be abandoned. In any event, the belief should be dispelled.

\section{CONCLUDING REMARKS}

For a small country, Sweden has created a large pool of talent in professional economic research. It is our observation that this talent is 


\section{Views of the international evaluation committee}

being used efficiently and productively in some parts of economics and in some institutions. In others, ambitions are less well focused and abilities less completely utilized.

The system of postgraduate education is generally weak. The most serious flaw is the decentralization that causes departments to operate on an inefficiently small scale, in excessive isolation from one another.

In research and in postgraduate training as well, the problems are exacerbated by the lack of appropriate incentives and career paths. Some lingering traditions, like writing monographic theses, and spending one's entire career from undergraduate studies to retirement at the same institution, are further obstacles to efficiency.

We have suggested some measures that could build on the special strengths of the system and improve it at the weak points. The key points deserve particular emphasis: small topical research groups, unified research and teaching career tracks in universities, reorganization of the financing of postgraduate study, the creation of intensive national postgraduate courses for second-year students, and the provision of scholarships to send a few top students to the best postgraduate programmes abroad.

We hope that our recommendations will make the strongest elements in Swedish economics even stronger and will help to give Swedish economics as a whole an even more prominent place in the international community of teachers and research workers. 


\section{Appendix A}

Time sshedule for the evaluation project

\begin{tabular}{|c|c|}
\hline Point of time & Activity \\
\hline 30 November & Meeting with Swedish economics \\
\hline 1988 & professors (two from each department) \\
\hline Late autumn 1988 & Commission of Background Reports \\
\hline 26 January 1989 & $\begin{array}{l}\text { Decision by the Research Council to undertake } \\
\text { the evaluation }\end{array}$ \\
\hline Spring 1989 & $\begin{array}{l}\text { Collection and processing of material from the } \\
\text { departments }\end{array}$ \\
\hline March 1989 & $\begin{array}{l}\text { Appointment of the international evaluation } \\
\text { committee }\end{array}$ \\
\hline September 1989 & $\begin{array}{l}\text { Delivery of background material to the } \\
\text { committee }\end{array}$ \\
\hline $\begin{array}{l}18 \text { November } \\
1989\end{array}$ & $\begin{array}{l}\text { Meeting of the international evaluation } \\
\text { committee in Stockholm. Decision on time } \\
\text { schedule, etc. }\end{array}$ \\
\hline 22 March 1990 & $\begin{array}{l}\text { Site visits in the Stockholm School of } \\
\text { Economics and the Swedish Institute for Socia } \\
\text { Research }\end{array}$ \\
\hline 23 March 1990 & $\begin{array}{l}\text { Site visits in the Stockholm School of } \\
\text { Economics and the Department of Economics, } \\
\text { Stockholm University }\end{array}$ \\
\hline 24 March 1990 & $\begin{array}{l}\text { Site visit in the Department of Economics, } \\
\text { Gothenburg University }\end{array}$ \\
\hline 26 March 1990 & $\begin{array}{l}\text { Site visit in the Department of Economics, } \\
\text { Lund University }\end{array}$ \\
\hline 27 March 1990 & $\begin{array}{l}\text { Site visits in the Trade Union Institute for } \\
\text { Economic Research, Stockholm and the }\end{array}$ \\
\hline
\end{tabular}


188 Appendix A

\begin{tabular}{ll}
\hline Point of time & Activity \\
\hline 28 Maish 1990 & $\begin{array}{l}\text { Industrial Institute for Economic and Social } \\
\text { Research, Stockholm } \\
\text { Site visit in the Department of Economics, } \\
\text { Umeå University } \\
\text { Site visit in the Institute of International } \\
\text { Economic Studies, Stockholm University and } \\
\text { the National Institute of Economic Research }\end{array}$ \\
30 March 1990 & $\begin{array}{l}\text { Site visit in the Department of Economics, } \\
\text { Uppsala University }\end{array}$ \\
12-14 December & $\begin{array}{l}\text { Meeting of the international evaluation } \\
\text { committee to discuss chapter drafts and the } \\
\text { final work }\end{array}$ \\
1590 February 1991 & $\begin{array}{l}\text { Delivery of revised versions } \\
\text { Delivery of final versions } \\
\text { 30 May 1991 }\end{array}$ \\
$\begin{array}{l}\text { June-July 1991 } \\
\text { Copy-editing } \\
\text { 18 September 1991 }\end{array}$ & $\begin{array}{l}\text { Reproduction of draft version } \\
\text { Seminar with Swedish economics professors }\end{array}$ \\
$\begin{array}{l}\text { September- } \\
\text { November 1991 }\end{array}$ & $\begin{array}{l}\text { Revisions } \\
\text { 30 November 1991 }\end{array}$ \\
\hline
\end{tabular}




\title{
Appendix B \\ Professors of economics in Sweden \\ 1741-1989
}

\author{
Elving Gunnarsson
}

\section{INTRODUCTION}

This appendix is the outcome of an attempt to define the population of Swedish economics professors 1889-1989 with reference to Chapter 2. The professors discussed in that chapter are listed in the third section of this appendix. Earlier Swedish professors of economics are listed in the second section under the heading 'Ancestors', The ancestors include the first professor of economic sciences, Professor Anders Berch, who in 1741 at Uppsala University became the fourth professor in this discipline in the world (Liedman 1986: 27). Professors who were formally appointed in the economic sciences but who devoted themselves to botanical subjects have been excluded from the list.

Most of the information has been retrieved from Sveriges statskalender (the Swedish State Calendar) 1865-1989. Supplementary information has been found in historical works such as Weibull and Tegnér (1868), Andersson (1898) and Annerstedt (1912-14). Various biographical encyclopaedias such as Svenska män och kvinnor (Swedish men and women 1942-55), Svenskt biografiskt lexikon (Swedish biographical encyclopaedia 1918-87) and Vem är det (Who's who 1912-90) have also been used.

To be included in the table a person must have been labelled in Sveriges statskalender as a professor in a department of Economics at one of the universities of Gothenburg, Lund, Stockholm, Umeå or Uppsala, or at the Schools of Economics in Gothenburg or Stockholm. Thus some people labelled as professors of Economics and related subjects are excluded. During the early period, for instance, there were Swedish professors in regions which do not now belong to Sweden, e.g. Pehr Kalm and other professors at the Academy of Åbo, Finland.

In the modern period several other professors have been excluded. 


\section{0}

Appendix $B$

Most of these are professors at other institutes, such as the College of Forestry, the Royal Institute of Technology and the University of Linköping or in other departments, such as Statistics.

Some of the professors have been known at certain times by other names such as preceptor or biträdande professor, and have later without any other change in their position - been given the full title of professor. They are included in the table only for the period during which they held the title of professor.

The exclusions are motivated by the difficulty in finding any other clearcut definition of the economics domain, and by the absence of any source material which would make it possible to distinguish between cases where titles other than professor have been equivalent to that title, and cases where they have not.

Below is a sample of the information given in the table regarding the modern professors:

Lindahl, Erik Robert, 1891-1960, Jur.dr. and Fil.kand. 1932-8 Economics with Statistics, Gothenburg School of Economics; 1938-42 Economics and Fiscal Law, Lund; 1942-58 Economics and Fiscal Law, Uppsala.

\section{Explanation}

Lindahl, Erik Robert = Surname, first names. The first name by which the person is generally known is italicized.

1891-1960 = Dates of birth and death.

Jur.dr. and Fil.kand. = academic degrees. The first academic degree is given together with the doctor's degree when the degrees refer to different subjects, as for instance Palander's first degree in the technological field.

1932-8 = Duration of professorship.

Economics with Statistics $=$ Specification of discipline.

Gothenburg Scool of Economics = Name of institution. In the case of Lund, Umeå and Uppsala only professors at the universities are included. The universities of Gothenburg and Stockholm are referred to as universities even before they were formally granted that designation in 1954 and 1960 respectively.

\section{ANCESTORS (1741-1889)}

Agardh, Carl Adolph, 1785-1859. Fil.dr., 1812-35: Botany (and Practical Economics), Lund University. Left to become bishop in Karlstad.

Berch, Anders, 1711-74. Disp pro exercitio and Jur.dr. (Honorary 
degree), 1741-70: Jurisprudentiæ, oeconomiæ et commerciorum, Uppsala University. Left to become university treasurer.

Berch, Christer, 1735-92. 1773-87: Jurisprudentiæ, oeconomiæ et commerciorum, Uppsala University. Fired from the professorship.

Bergfalk, Pehr, Erik, 1798-1890, Fil.dr. and Jur.dr., 1838-61: Jurisprudentiæ, oeconomiæ et commerciorum, Uppsala University.

Burmester, Johan Henrik, 1720-70. Fil.mag., 1750-6: Economic Sciences, Lund University. Left as professor of Latin Rhetoric and Poetry.

Christiernin, Pehr Niclas, 1725-99. Fil.mag., 1770-1: Jurisprudentiæ, oeconomiæ et commerciorum, Uppsala University. Swapped chair with Frosterus.

Flygare, Gustaf, 1743-1805. 1787-1805: Jurisprudentiæ, oeconomiæ et commerciorum, Uppsala University.

Frosterus, Henric, 1727-72. 1772: Jurisprudentiæ, oeconomiæ et commerciorum, Uppsala University.

Hamilton, Gustaf Axel Knut, 1831-1913. Jur.dr., 1862-1903: Public Law and Economics, from 1899 in Special Private Law, Lund University. Emeritus 1903.

Hammarskjöld, Carl Gustaf, 1838-98. Jur.utr.kand, Jur.dr. and Fil.dr., 1877-89: Economics and Fiscal Law, Uppsala University.

Holmbergsson, Johan, 1764-1842. Fil.mag. and Jur.lic., 1838-42: Economic and Fiscal Law, Lund University.

Lundell, Jacob, 1813-52. Fil.dr., 1844-52: Economic and Fiscal Law, Lund University.

Rabenius, Lars Georg, 1771-1846. Fil.mag. and Jur.dr., 1807-37: Economics, Industrial, Financial and Political Law, Uppsala University.

Rabenius, Olof Mathias Theodor, 1823-92. Fil.mag. and Jur.dr. utr.kand., 1854-62: Public Law and Economics, Lund University; 1862-89 Economics, Industrial, Financial and Political Law, Uppsala University.

Trozelius, Claes Blechert, 1719-94. Fil.mag., 1758-86: Economic Sciences, Lund University.

Zetterstedt, Johan Wilhelm, 1785-1865. Fil.dr., 1839-53: Botany (and Practical Economics), Lund University.

\section{MODERN AGE (1889-1989)}

Åkerman, Johan Gustaf, 1888-1959. Jur.dr., 1931-53: Economics and Sociology, Gothenburg University.

Åkerman. Johan Henrik. 1896-1982. Fil.dr. and Civ.ekon.. 1943-61: 


\section{Appendix B}

Economics with Fiscal Law, Lund University.

Andersson, Ake Emanuel, 1936- . Fil.lic., 1979- : Regional economics, Umeå University.

Artle, Kurt Roland Arthur, 1926- . Ekon.dr., 1965-8: Economics, Gothenburg University. Left to go to Berkeley.

Arvidsson, Guy Nils Arvid, 1918-73. Fil.lic., 1961-9: Economics, Lund University; 1969-73: Economics, Stockholm University.

Bagge, Gösta Adolfsson, 1882-1951. Fil.dr. and Tekn.dr. (Honorary degree), 1921-49: Economics and Social Policy, Stockholm University.

Bentzel, Ragnar H:son, 1919- . Fil.dr., 1959-65: Economics with Statistics, Stockholm School of Economics; 1965-85: Economics, Uppsala University.

Bergman, Lars Daniel, 1945- . Ekon.dr., 1984- : Economics with special focus on Energy and Environment, Stockholm School of Economics.

Blomquist, Sören, 1948- . Ph.D., 1985- : Economics, Particularly the Economics of the Public Sector, Stockholm University.

Bohm, Jan Peter Gunnar, 1935- . Fil.lic., 1975- : Economics, Stockholm University.

Brisman, Sven Bernhard, 1881-1953. Fil.dr., 1917-46: Economics with Bank Science, Stockholm School of Economics.

Brock, Fritz Pär Hansson, 1877-1956. Jur.dr., 1921-42: Economics and Fiscal Law, Uppsala University.

Burenstam Linder, Hans Martin Staffan, 1931- . Ekon.dr., 1979- : International Economics, Stockholm School of Economics.

Calmfors, Lars, 1948- . Ekon.dr., 1988- : International Economics, Institute for International Economic Studies, Stockholm University.

Cassel, Karl Gustav, 1866-1945. Jur.dr. (Honorary degree) and Fil.dr., 1904-33: Economics with Public Finance, Stockholm University.

Dahmén, Erik Verner Harald, 1916- . Fil.dr., 1958-85: Economics with Economic and Social History, Stockholm School of Economics.

Davidson, David, 1854-1942. Jur.utr.kand., Jur.dr. and Fil.dr. (Honorary degrees), 1889-1919: Economics and Fiscal Law, Uppsala University.

Dickson, Harald Axel Engelbert, 1912- . Fil.dr. and Pol.mag., 195578: Economics, Gothenburg School of Economics, from 1971 Gothenburg University.

Englund, Peter, 1950- . Ekon.dr., 1988- : Economics, particularly Analysis of Capital Markets, Uppsala University.

Gårdlund, Torsten Waldemar, 1911- . Fil.dr.. 1947-63: Economics 
and Banking, Stockholm School of Economics. 1965-77 International Economics, Lund University.

Hansen, Bent, 1920 - . Fil.dr., 1965-7: Economics, Stockholm University. Left to go to Berkeley.

Hansson, Hans Arnold Per Ingemar, 1951- . Fil.dr., 1988- : Economics, particularly Public Economics, Lund University.

Heckscher, Eli Filip, 1879-1952. Fil.dr., 1909-29: Economics with Statistics, Stockholm School of Economics; 1929-45 Economic History.

Hegeland, Hugo Oscar, 1922- . Fil.dr., 1965-9: Economics, Umeå University.

Hjalmarsson, Anders Lennart, 1944- . Ekon.dr., 1979- : Economics, Gothenburg University.

Höglund, Bengt Lennart, 1921- . Fil.dr., 1979-87: Economics, Lund University.

Holmlund, Bertil, 1947- . Fil.dr., 1987- : Economics, Uppsala University.

Johansson, Alf Hilding, 1901-81. Fil.dr., 1960-7: (Professor's title without a chair) Economics, particularly Building Market Research, Stockholm University.

Johansson, Börje Anders, 1945- . Ekon.dr., 1987- : Regional Economics, Umeå University.

Jonung, Jon Lars Birger, 1944- . Ph.D., 1988- : Economics particularly Macroeconomics and Economic Policy, Stockholm School of Economics.

Jungenfelt, Karl Gustav, 1931- . Fil.dr., 1972- : Economics, Stockholm School of Economics.

Klevmarken, Nils Anders, 1941- . Fil.dr., 1985- : HSFR professor of Econometrics, Gothenburg University. Professor in Statistics 197685 at Gothenburg University.

Kock Lindberg, Karin, 1891-1976, Fil.dr., 1945-58: (Professor's title without a chair), Economics, Stockholm University.

Kragh, Börje Robert Viktor, 1918- . Fil.dr., 1962-5: Economics, Gothenburg University; 1968-84: Economics, particularly research on Business Cycles, Stockholm University.

Lindahl, Erik Robert, 1891-1960. Jur.dr. and Fil.Kand., 1932-8: Economics with Statistics, Gothenburg School of Economics; 193842: Economics and Fiscal Law, Lund University; 1942-58: Economics and Fiscal Law, Uppsala University.

Lindbeck, Carl Assar Eugen, 1930- . Fil.dr., 1964-71: Economics, Stockholm School of Economics; 1971 - : International Economics, Institute for International Economic Studies, Stockholm University. 
Löfgren, Karl-Gustaf, 1943- . Fil.dr., 1988- : Economics, Umeå University. Professor in Forestry Economics 1979-88 at the College of Forestry at Umeå University.

Lundahl, Mats Ove, 1946- . Ekon.dr., 1987- : Development Economics, Stockholm School of Economics.

Lundberg, Erik Filip, 1907-87. Fil.dr., 1946-65: Economics, particularly research on Business Cycles, Stockholm University; 1965-74: Economics, Stockholm School of Economics.

Lybeck, Johan Göran August, 1944- . Ph.D., 1978- : Economics, Gothenburg University.

Mäler, Karl-Göran, 1939- . Fil.dr., 1979- : Economics, Stockholm School of Economics.

Montgomery, Gustaf Arthur, 1889-1976. Fil.dr., 1940-58: Economic and Social History from 1954 Economics with Economic and Social History, Stockholm School of Economics. Professor in Economics and Public Finance 1924-39 at the Åbo Academy.

Myhrman, Johan Carl Didrik, 1937- . Fil.dr. and Pol.mag., 1984- : Economics, Stockholm School of Economics.

Myrdal, Karl Gunnar, 1898-1987. Jur and Fil.dr. (Honorary degree), 1933-50: Economics with Public Finance, Stockholm University; 1960-7: International Economics, Institute for International Economic Studies, Stockholm University. Professor 1930-1 at the International College of Geneva.

Ohlin, Bertil Gotthard, 1899-1979. Fil.dr., 1929-65: Economics, Stockholm School of Economics. Professor in Economics 1924-9 at the University of Copenhagen.

Ohlin, Per Göran, 1925- . Jur.dr. (Honorary degree) and Ph.D., 196986: Economics, Uppsala University.

Östlind, Anders Elof, 1914- . Fil.dr. and Ekon.mag., 1953-79: Economics and Social Policy, Stockholm University.

Palander, Tord, F:son, 1902-72. Fil.dr. and Civ.ing., 1941-8: Economics with Statistics, Gothenburg School of Economics; 1948-69: Economics, Uppsala University.

Persson, Mats, 1949- . Ekon.dr., 1989- : Economics, Institute for International Economic Studies, Stockholm University.

Persson, Torsten, 1954- . Fil.dr., 1987- : International Economics, Institute for International Economic Studies, Stockholm University. Philip, Kjeld, 1912-89. Dr.oecon., 1949-51: Economics with Social Policy, Stockholm University.

Puu, Tönu, 1936- . Fil.dr., 1971- : Economics, Umeå University.

Rehn, Lars Gösta, 1913- . Fil.lic., Socionom and Ekon.dr. (Honorary degree), 1973-9: Labour Market Policy, Swedish Institute for 
Social Research, Stockholm University.

Ruist, Erik Harald, 1921 - . Fil.dr., 1966-86: Economic Statistics with Economics, Stockholm School of Economics.

Silverstolpe, Karl Gunnar Mannerheim (Westin), 1891-1975. Fil.dr., 1923-32: Economics, Gothenburg School of Economics.

Siven, Axel Claes-Henric, B:son, 1940 - . Fil.dr., 1979- : Economics, particularly Economic Policy, Stockholm University.

Södersten, Bo Åke, 1931- . Fil.dr., 1971-7: Economics, Gothenburg University; 1977- : International Economics, Lund University.

Södersten, Jan, 1943 - . Fil.dr., 1989- : Economics, particularly Taxation of Business, Uppsala University.

Sommarin, Emil Fritiof Knut, 1874-1955. Fil.dr. and Jur.kand., 1919-39: Economics and Fiscal Law, Lund University.

Ståhl, Ingemar Oskar Lennart, 1938- . Fil.lic., 1971- : Economics, Lund University.

Steffen, Gustaf Fredrik, 1864-1929. Dr.phil., 1903-29: Economics and Sociology, Gothenburg University.

Sundbom, Ivar Natanael, 1895-1964. Fil.dr., 1949-53: Economics with Statistics, Gothenburg School of Economics; 1953-62: Economics, Gothenburg University.

Svennilson, Sven Ingvar, 1908-72. Jur.dr. (Honorary degree) and Fil.dr., 1947-72 Economics, particularly Industrial Economics; from 1951 Economics with Public Finance, Stockholm University and from 1967 International Economics, Institute for International Economic Studies, Stockholm University.

Svensson, Lars Erik Oskar, 1947- . Fil.dr., 1984- : International Economics, Institute for International Economic Studies, Stockholm University.

Thalberg, Björn Thorgeir, 1924- . Cand.oecon., Dr.phil., 1968-90: Economics, Lund University.

Wadensjö, Eskil Göran, 1944- . Fil.dr., 1980- : Labour Market Policy, Stockholm University.

Welinder, Per Emil Carsten, 1908-82. Jur.dr. and Fil.dr. (Honorary degree), 1948-74: Fiscal Law and Public Finance, Lund University.

Werin, Lars Henrik Vitalis, 1928- . Fil.dr., 1969- : Economics, Stockholm University.

Wicksell, Johan Gustaf Knut, 1851-1926. Jur.dr. (Honorary degree) and Fil.dr., 1901-16: Economics and Fiscal Law, Lund University.

Wihlborg, Clas, 1947- . Ph.D., 1988- : Banking and Financial Economics, Gothenburg University.

Ysander, Bengt-Christer Algot, 1931- . Fil.lic., 1985- : Economics, Uppsala University. 


\title{
Appendix C \\ The role of institutions
}

\author{
Lars Jonung
}

In the main text the incentive structure and behaviour of the 'average' professor has been considered. However, the development of economics in Sweden is also linked to the performance of a number of institutions. In this section the focus will be shifted away from the professorial corps, turning briefly instead on three institutions that have been instrumental in forming Swedish economics: the Stockholm School of Economics, the Department of Economics at Lund University, and the Institute for International Economics Studies in Stockholm. Naturally other institutions apart from these three have played an important part in the development of Swedish economics, such as the Industrial Institute for Economic and Social Research and the Department of Economics at Stockholm University.

The reasons for focusing on the Stockholm School of Economics, the Department of Economics at Lund and the Institute for International Economic Studies in Stockholm are as follows. The Stockholm School of Economics is the only private school of academic economics. As such it has been highly successful, functioning as an innovator in the field of economics. The department at Lund has been the most prolific producer and exporter of professors in the Swedish system in the period since the Second World War. Finally, the research and publication record of the Institute for International Economic Studies in the 1970s and 1980s illustrates how academic entrepreneurship can flourish within the public university system.

\section{THE STOCKHOLM SCHOOL OF ECONOMICS}

The Stockholm School of Economics occupies a unique position as the only private institute of higher learning in Sweden. The School was founded in 1909 with the active support of the Wallenberg family and has been supported by the Wallenberg group and Swedish industry 
ever since. The aim of the School was 'through scientific education and research to foster and promote business activities in our country', and the way to reach this goal proved to be by providing a thorough training in economics. According to Olsson (1989), the influence of Eli Heckscher on the curriculum of the new School was extremely important, and the subject of economics became the basis of the courses at the new business school.

As a private school not subject to direct government regulation, the Stockholm School of Economics has been able to act as entrepreneur in the Swedish university system. It has used this position in a number of ways. The School introduced economics as a separate subject, detached from law, in 1909 when Eli Heckscher was appointed to the first chair in economics. A second chair was established in 1917. The first chairs in pure economics, i.e. outside the law faculty, were set up in the late 1940s at the national universities. The Stockholm School of Economics also introduced economic history as a separate field, when Eli Heckscher was given a personal chair in this subject in 1929. Later the national university system followed suit. The School was first in establishing a chair in business administration (initially handelsteknik, later företagsekonomi) - and in econometrics (ekonomisk statistik). It is also the first and only place of higher learning to have abolished the position of lektor (lecturer) in the 1980s. A number of other academic innovations stem from the Stockholm School of Economics, such as the establishment of the first department of financial economics in recent years.

The subject of economics in Sweden has benefited from the strong position it was once given, and which it has managed to maintain, at the Stockholm School of Economics. The training provided and the degree awarded at the School, the civilekonomexamen, are regarded as the best, and the entrance requirements for the School are therefore at present the highest in Sweden. The designation of the degree and the educational programme, including the position occupied by economics (nationalekonomi), have been adopted at all state-controlled universities. Economics accounts for roughly 20 per cent of the study load in the first degree course. At present this programme (ekonomlinjen) is available at 17 universities and colleges in Sweden. It is the largest undergraduate programme in the Swedish university system, with 2,450 student places in 1989-90.'

The Stockholm School of Economics still serves as the market leader, even though the School accounts for less than 10 per cent of the first degrees awarded annually. 


\section{8}

Appendix $C$

\section{LUND UNIVERSITY}

Outside Stockholm the Department of Economics at Lund has been the major granter of higher degrees, i.e. of old and new licentiates and doctorates. It is also the main producer of licentiates and doctors who became professors in the post-war period in Sweden, inter alia Erik Dahmén, Bengt-Christer Ysander, Börje Kragh, Lars Werin, Eskil Wadensjö, Bengt Jönsson, Mats Lundahl, Lars Jonung and Stefan Hedlund, and of others who became professors outside Sweden such as Rolf Färe (University of Southern Illinois, Carbondale), Charles Stuart (UC Santa Barbara), Carl Sandblom (University of Montreal) and Rögnvaldur Hannesson (Bergen). No other department can match this record. ${ }^{2}$

The department, whose roots go back to Pufendorf's appointment to a chair in the 1660s, was headed by Johan Åkerman in the 1940s and 1950s. Åkerman created a modern-style department with a library, a seminar room and regular seminar activities. He maintained a broad and tolerant approach towards economics, encouraging studies in a wide variety of fields, some close to political science, economic history and history, others bordering on mathematics and game theory. The Åkerman tradition continued in the 1970s, when Lund pioneered a number of doctoral theses in fields new to Sweden such as law and economics, and health economics. Development economics, international trade, and taxation are other strong fields. ${ }^{3}$

There are two main factors that may explain Lund's performance compared with that of other departments. First, Lund is quite far away from Stockholm. The alternatives to doing research are fewer than in the capital, where there is the temptation to enter politics, to go into consulting or to find some better paid job. At Lund, currently the biggest university in Scandinavia, research and teaching are more likely to offer the main openings. And because this is a small town, the department has become a natural meeting-place, socially and academically, in a way that is difficult for a department in a large city, many of whose members have to commute long distances.

A second factor that helps to explain Lund's performance is the relatively large size of the department, in particular the large number of docents. This group has been active in advising new doctoral students and creating an attractive academic environment, even when some of the professors had to be absent for various reasons in Stockholm. However, in recent years, Lund has not been able to match the expansion of new chairs in Stockholm and Uppsala, and its productivity appears to have declined somewhat. 


\section{THE INSTITUTE FOR INTERNATIONAL ECONOMIC STUDIES}

When the history of Swedish economics in the 1970s and 1980s is written, the Institute for International Economic Studies in Stockholm (IIES) will be given a prominent place. Gunnar Myrdal was the driving force behind the establishment of the Institute in 1961. $\mathrm{He}$ also became its first head. His idea was to break away from the confines of traditional economics and to set up a truly interdisciplinary institute including sociologists, psychologists, historians, legal experts, etc. to broaden the study of international economics.

Under the energetic leadership of Assar Lindbeck from 1971 onwards, the Institute has not developed in an interdisciplinary direction; instead it has become the leading centre of research in economics in Sweden. During the Institute's formative years its members were in a privileged position, in the sense that they were fairly isolated from the traditional Swedish university system and allowed to concentrate on research in international economics with only minor obligations to teach or supervise students. In the late 1980 s members of the Institute have become more involved in the postgraduate and undergraduate programmes at Stockholm University. Compared with the standard Swedish economics departments the Institute has been lavishly funded, allowing for a steady flow of foreign academic visitors as well as foreign visits by its members. ${ }^{4}$ In this way the members of the Institute have become linked into various international networks on a scale unmatched anywhere else in Sweden. Nor has the perceived closeness to the connection between the Institute and the award of the Nobel Prize in economics been detrimental to building up international contracts.

The environment created at the Institute has been highly conducive to research. The Institute now occupies a strong position in international economics both in and outside Sweden. Members of the Institute have been successful in publishing in international journals. Several of them have been appointed professors at the Institute in the 1980s (table 2.1). Four new chairs were established in the 1980s, a number unique in the Swedish context. So far no outsiders, only insiders, have been able to compete successfully for these chairs. 


\title{
Appendix D \\ Doctoral theses in economics in Sweden 1895-1989
}

\author{
Eskil Wadensjö
}

\section{INTRODUCTION}

This appendix contains information on the theses in economics in Sweden from Knut Wicksell's thesis Zur Lehre von der Steuerincidenz in 1895 up to the Ph.D. theses in 1989.' In addition to the theses listed here Swedish economists have also presented a large number of licentiate theses. For reasons of space it has not been possible to include these here, but they will be presented in a Research Report from the Swedish Institute for Social Research. ${ }^{2}$

OLD PH.D. DEGREES (1895-1973)

\section{5}

Wicksell, Knut (b. 1851), Zur Lehre von der Steuerincidenz (On the Theory of Tax Incidence), Area: 320, Uppsala University, Opponent: David Davidson, Uppsala University.

\section{9}

Lembke, Johan Christopher (b. 1868), Ueber einige Bestimmungsgründe des Arbeitslohnes (Some Factors Determining Wages), Area: 810, Lund University (Faculty of Law), Opponent: Gustaf Hamilton, Lund University.

\section{2}

Stjernberg, Nils (b. 1873), Till frågan om de s $k$ rent ekonomiska kategorierna (A Contribution to the Question of Purely Economic Categories), Area: 030, Uppsala University (Faculty of Law), Opponent: N. Reuterskiöld, Uppsala University. 
Heckscher, Eli (b. 1879), Till belysning af järnvägarnas betydelse för Sveriges ekonomiska utveckling (On the Contribution of Railways to Economic Development in Sweden), Area: 040, Uppsala University, Opponent: Nils Stjernberg, Stockholm University.

1908

Sommarin, Emil (b. 1874), Bidrag till kännedom om arbetareförhållanden vid svenska bergverk och bruk $i$ äldre tid till omkring ar 1720 (Contributions to the Knowledge of Workers' Conditions in Swedish Mines and Manufacturing in the Period up to c. 1720), Area: 040, Lund University, Opponent: Eli Heckscher, Stockholm University.

1909

Brock, Fritz (b. 1877), Om den ekonomiska fördelningen och kriserna (On Income Distribution and the Economic Crises), Area: 130, Uppsala University (Faculty of Law), Opponent: David Davidson, Uppsala University.

\section{1}

Marcus, Moritz (b. 1877), Den svenska tobaksindustrien år 1908 (The Swedish Tobacco Industry in 1908), Area: 630, Gothenburg University, Opponent: Emil Sommarin, Lund University.

Östman, Hugo (b. 1865), 'Norrlands ekonomiska utveckling sedan mitten av 1800-talet' (Norrland's Economic Development since the mid-19th Century), Area: 040, Gothenburg University, Opponent: Gustaf Steffen, Gothenburg University.

\section{2}

Petander, Karl (b. 1883), De nationalekonomiska åskådningarna $i$ Sverige sådana de framträda $i$ litteraturen. I. 1718-1765 (Economic Theory in Sweden According to Published Material. I. 1718-1765), Area: 030, Stockholm University, Opponent: Eli Heckscher, Stockholm School of Economics (HHS). 
1913

Wohlin, Nils (b. 1881), Den svenska jordstyckningspolitiken i de 18:de och 19:de århundradena jämte en öfversikt af jordstyckningens inverkan på bondeklassens besuttenhetsförhållanden (Swedish Policy Regarding the Division of Agricultural Property in the 18th and 19th Centuries and a Survey of its Effects on the Distribution of Wealth Among Peasants), Area: 040, Stockholm University, Opponent: Gustaf Ribbing, Uppsala University.

\section{5}

Persson, Frithiof (b. 1882), Om Malmö hamn. Dess ekonomiska utveckling och funktioner (On the Port of Malmö. Economic Development and Economic Functions), Area: 610, Lund University, Opponent: Emil Sommarin, Lund University.

Åmark, Karl (b. 1883), Spannmålshandel och spannmålspolitik $i$ Sverige 1719-1830 (Grain Trade and Grain Policy in Sweden 17191830), Area: 040, Stockholm University, Opponent: Nils Wohlin, Stockholm University.

\section{7}

Bagge, Gösta (b. 1882), Arbetslönens reglering genom sammanslutningar (The Regulation of Wages by Organizations), Area: 820, Stockholm University, Opponent: Sven Brisman, Stockholm School of Economics (HHS).

\section{9}

Lindahl, Erik (b. 1891), Die Gerechtigkeit der Besteurung. Eine Analyse der Steuerprinzipien auf grundlage der Grenznutzentheorie (The Correct Method of Taxation. An Analysis of the Principle of Taxation based on Marginal Utility Theory), Area: 320, Lund University (Faculty of Law), Opponent: Knut Wicksell, Lund University.

Silverstolpe, Gunnar (b. 1891), Kapitalbildning, en teoretisk-ekonomisk undersökning (Capital Formation, a Theoretical and Economic Investigation), Area: 022, Stockholm University, Opponent: Gösta Bagge, Stockholm University. 
1921

Rohtlieb, Curt (b. 1880), Gränsproduktiviteten hos jordbrukets produktionsfaktorer. En kritik av jordproduktivitetslagen (Marginal Productivity in Agriculture. A Criticism of the Law of Marginal Productivity of Land), Area: 710, Lund University (Faculty of Law), Opponent: Erik Lindahl, Lund University.

1923

Åkerman, Gustaf (b. 1888), Realkapital und Kapitalzins (Real Capital and the Rate of Return), Area: 022, Lund University, Opponent: Erik Lindahl, Lund University.

1924

Cassel, Margit (b. 1897), Die Gemeinwirtschaft. Ihre Stellung und Notwendigkeit in der Tauschwirtschaft (Common Property. Its Role and its Necessity in a Barter Economy), Area: 320, Stockholm University, Opponent: Bertil Ohlin, Stockholm University.

Ohlin, Bertil (b. 1899), Handelns teori (The Theory of Trade), Area: 410, Stockholm University, Opponent: Gösta Bagge, Stockholm University.

1927

Myrdal, Gunnar (b. 1898), Prisbildningsproblemet och föränderligheten (Price Formation and the Rate of Change), Area: 020, Stockholm University (Faculty of Law), Opponent: Erik Lindahl, Stockholm University.

Prawitz, Gunnar (b. 1898), Det finansrättsliga inkomstbegreppet (The Income Concept in Fiscal Law), Area: 320, Stockholm University (Faculty of Law), Opponent: Curt Rohtlieb, Ministry of Agriculture, Stockholm.

\section{8}

Åkerman, Johan (b. 1896), Om det ekonomiska livets rytmik (Economic Cycles), Area: 023, Lund University, Opponent: Ragnar Frisch, University of Oslo. 


\section{Appendix D}

1929

Kock, Karin (b. 1891), A Study of Interest Rates, Area: 020, Stockholm University, Opponent: Sven Brisman, Stockholm School of Economics (HHS).

1933

Hammarskjöld, Dag (b. 1905), Konjunkturspridningen. En teoretisk och historisk undersökning (SOU 1933:29) (Business Cycles. A Theoretical and Historical Investigation), Area: 023, Stockholm University, Opponent: Gunnar Myrdal, Stockholm University.

Sundbom, Ivar (b. 1895), Prisbildning och ändamålsenlighet. En kritik av de teleologiska föreställningarna inom prisbildningsläran (Price Formation and Suitability. A Criticism of the Teleological Ideas of Price Theory), Area: 022, Gothenburg University, Opponent: Gustaf Åkerman, Gothenburg University.

\section{4}

Johansson; Alf (b. 1901), Löneutvecklingen och arbetslösheten (SOU 1934:2) (Wage Formation and Unemployment), Area: 023, Stockholm University, Opponent: Gunnar Myrdal, Stockholm University.

\section{5}

Palander, Tord (b. 1902), Beiträge zur Standorts-theorie (Contributions to the Theory of Location), Area: 730, Stockholm University, Opponent: Bertil Ohlin, Stockholm School of Economics (HHS).

Welinder, Carsten (b. 1908), Kommunala avgifter $i$ de svenska städernas hushållning särskilt med hänsyn till den kommunala affärsverksamheten (Charges as a Part of the Revenues of Swedish Cities with Special Regard to Local Government Business Activities), Area: 320, Lund University (Faculty of Law), Opponent: Erik Lindahl, Stockholm School of Economics (HHS).

\section{7}

Lundberg, Erik (b. 1907), Studies in the Theory of Economic Expansion, Area: 110, Stockholm University, Opponent: Alf Johansson, Stockholm University. 
Svennilson, Ingvar (b. 1908), Ekonomisk planering. Teoretiska studier (Economic Planning. Theoretical Studies), Area: 110, Stockholm University, Opponent: Tord Palander, Stockholm University.

1939

Fornmark, Erik (b. 1893), Skatteutjämningens problem (The Problem of Tax Equalization), Area: 320, Lund University (Faculty of Law), Opponent: Carsten Welinder, Lund University.

1942

Gårdlund, Torsten (b. 1911), Industrialismens samhälle (Industrial Society), Area: 040, Stockholm University, Opponent: Karin Kock, Stockholm University.

1944

Sterner, Richard (b. 1901), The Negro's Share. A Study of Income, Consumption, Housing and Public Assistance, Area: 930, Stockholm University, Opponent: Torsten Gårdlund, Stockholm University.

\section{5}

Ǒstlind, Anders (b. 1914), Svensk samhällsekonomi 1914-1922. Med särskild hänsyn till industri, banker och penningväsen (The Swedish Economy 1914-22 with Special Regard to Manufacturing, Banking and Monetary Systems), Area: 040, Stockholm University, Opponent: Torsten Gårdlund, Stockholm University.

\section{6}

Kristensson, Folke (b. 1914), Studier i svenska textila industriens struktur (Studies of the Structure of the Swedish Textile Industry), Area: 630, Stockholm School of Economics (HHS), Opponent: Gerhard Törnqvist, Stockholm School of Economics (HHS).

Lemne, Lars (b. 1916), Den framtida jordbruksproduktionens inriktning och omfattning (The Direction and Scale of Future Agricultural 
Policy), Area: 710, Uppsala University, Opponent: Erik Lindahl, Uppsala University.

\section{8}

Gerhard, Ingemar (b. 1912), Problem rörande Sveriges utrikeshandel 1936/38 (Problems Concerning Swedish Foreign Trade 1936/38), Area: 420, Gothenburg University, Opponent: Ivar Sundbom, Gothenburg University.

\section{9}

Dickson, Harald (b. 1912), Bostadsmarknaden i USA och Sverige. En komparativ strukturanalys med särskild hänsyn till förhållandet mellan egnahem och hyreslägenheter (The Market for Housing in the USA and Sweden. A Comparative Study with Special Regard to the Relation Between Owner-occupied Houses and Rented Apartments), Area: 930, Uppsala University, Opponent: Alf Johansson, Board of Housing, Stockholm.

Wallander, Jan (b. 1920), Flykten från skogsbygden. En undersökning $i$ Klarälvsdalen (The Flight from the Forests: A Study of Klarälvsdalen), Area: 820, Stockholm University, Opponent: Sven Dahl, Stockholm School of Economics (HHS).

\section{0}

Dahmén, Erik (b. 1916), Svensk industriell företagarverksamhet. Kausalanalys av den industriella utvecklingen 1919-1939 (Entrepreneurial Activities in Swedish Manufacturing. Causal Analysis of Industrial Development 1919-1939), Area: 610, Lund University, Opponent: Johan Åkerman, Lund University.

\section{1}

Hansen, Bent (b. 1920), A Study in the Theory of Inflation, Area: 023, Uppsala University, Opponent: Trygve Haavelmo, University of Oslo.

Hegeland, Hugo (b. 1922), The Quantity Theory of Money. A Critical Study of its Historical Development and Interpretation and a Restatement, Area: 023, Gothenburg University, Opponent: Erling Petersen, University of Bergen. 
Kragh, Börje (b. 1918), Prisbildningen på kreditmarknaden. Ränteteoretiska studier med särskild hänsyn till svenska förhållanden (Price Formation in the Credit Market. Studies in the Theory of Interest Rates with Special Regard to Swedish Conditions), Area: 023, Uppsala University, Opponent: Paul Nyboe Andersen, University of Copenhagen.

Kristersson, Helge (b. 1914), De socialekonomiska grupperna och samhällsekonomin (Socio-Economic Groups and the Economy), Area: 050, Lund University, Opponent: Kjeld Philip, University of Copenhagen.

Nyblén, Göran (b. 1925), The Problem of Summation in Economic Science. A Methodological Study with Applications to Interest, Money and Cycles, Area: 010, Lund University, Opponent: Oscar Morgenstern, Princeton University.

\section{3}

Bentzel, Ragnar (b. 1919), Inkomstfördelningen i Sverige (Income Distribution in Sweden), Area: 850, Uppsala University, Opponent: Bent Hansen, Stockholm University.

Ohlsson, Ingvar (b. 1918), On National Accounting, Area: 210, Stockholm University, Opponent: Erik Lindahl, Uppsala University.

\section{4}

Meidner, Rudolf (b. 1914), Svensk arbetsmarknad vid full sysselsättning (The Swedish Labour Market under Full Employment), Area: 820, Stockholm University, Opponent: Alf Johansson, Board of Housing, Stockholm.

Rydenfelt, Sven (b. 1911), Kommunismen $i$ Sverige. En samhällsvetenskaplig studie (Communism in Sweden. A Social Science Study), Area: 050, Lund University, Opponent: Folke Lägnert, Lund University.

\section{5}

Metelius, Bengt (b. 1915), Utlandstransaktionerna och den svenska ekonomin (SOU 1955:13) (International Transactions and the Swedish Economy), Area: 420, Stockholm University, Opponent: Ingvar Svennilson, Stockholm University. 


\section{Appendix $D$}

1956

Lindberger, Lars (b. 1919), Investeringsverksamhet och sparande. Balansproblem på lång och kort sikt (SOU 1956:10) (Investments and Savings. Problems of Balance in the Long and Short Run), Area: 310, Stockholm University, Opponent: Anders Östlind, Stockholm University.

Tullander, Boris (b. 1907), De ekonomiska idéernas utveckling med särskild hänsyn till värdeteorin (The Development of Economic Ideas with Special Regard to the Theory of Value), Area: 030, Uppsala University, Opponent: Ivar Sundbom, Gothenburg University.

1957

Faxén, Karl Olof (b. 1924), Monetary and Fiscal Policy under Uncertainty, Area: 023, Stockholm University, Opponent: Anders Östlind, Stockholm University.

\section{9}

Ambjörn, Erik (b. 1916), Svenskt importberoende 1926-1956. En ekonomisk-statistisk kartläggning med kommentarer (Sweden's Dependence on Imports 1936-1956. An Economic-Statistical Investigation with Comments), Area: 420, Gothenburg University, Opponent: Ingemar Gerhard, Gothenburg University.

Åkerlund, Henrik (b. 1914), Guldparistandarden. Internationellt penningsystem och ekonomiskt program (The Gold Standard. The International Monetary System and Economic Performance), Area: 040, Uppsala University, Opponent: Tord Palander, Uppsala University.

\section{0}

Elmér, Åke (b. 1910), Folkpensioneringen i Sverige med särskild hänsyn till ålderspensioneringen (The National Pension System in Sweden with Special Regard to Old Age Pensions), Area: 910, Lund University, Opponent: Jörgen Dich, Århus University.

Landgren, Karl-Gustav (b. 1912), Den 'nya ekonomien'i Sverige. J.M. Keynes, E. Wigforss, B. Ohlin och utvecklingen 1927-39 (The 'New Economics' in Sweden. J.M. Keynes, E. Wigforss, B. Ohlin and the 
Development 1927-39), Area: 030, Gothenburg University, Opponent: Tor Fernholm, Gothenburg University.

1961

Burenstam Linder, Staffan (b. 1931), An Essay on Trade and Transformation, Area: 410, Stockholm School of Economics (HHS), Opponent: Charles P. Kindleberger, Massachusetts Institute of Technology.

Nabseth, Lars (b. 1928), Löneökningars verkningar inom industrin. En studie av anpassningsprocessen inom företaget (The Effects of Wages in Manufacturing. A Study of the Process of Adjustment of the Firm), Area: 820, Stockholm School of Economics (HHS), Opponent: Karl Olof Faxén, Swedish Employers' Confederation (SAF).

Thore, Sten (b. 1930), Household Saving and the Price Level, Area: 023, Stockholm University, Opponent: Trygve Haavelmo, University of Oslo.

\section{2}

Höök, Erik (b. 1920), Den offentliga sektorns expansion. En studie av de offentliga civila utgifternas utveckling åren 1913-58 (The Expansion of the Governmental Sector. A Study of the Development of Non-Military Expenditures in 1913-58), Area: 320, Stockholm University, Opponent: Göran Ohlin, Stockholm University.

\section{3}

Lindbeck, Assar (b. 1930), A Study in Monetary Analysis, Area: 023, Stockholm University, Opponent: Erik Lundberg, Stockholm University.

\section{4}

Puu, Tönu (b. 1936), Studier $i$ det optimala tillgångsvalets teori (Studies in the Theory of Optimal Allocation of Resources), Area: 020, Uppsala University, Opponent: Harald Dickson, Stockholm School of Economics (HHS). 


\section{Appendix D}

Södersten, Bo (b. 1931), A Study of Economic Growth and International Trade, Area: 410, Stockholm University, Opponent: Tore Thonstad, University of Oslo.

Åberg, Yngve (b. 1924), Arbetstidsförkortningens verkningar (SOU 1964:9) (The Effects of Shorter Working Hours), Area: 820, Stockholm University, Opponent: Gerhard Stolz, Norwegian School of Economics (Bergen).

\section{5}

Werin, Lars (b. 1928), A Study of Production, Trade and Allocation of Resources, Area: 210, Stockholm University, Opponent: Paul Nørregaard Rasmussen, University of Copenhagen.

\section{6}

Höglund, Bengt (b. 1921), Modell och observationer. En studie av empirisk anknytning och aggregation för en linjär produktionsmodell (Model and Observations. A Study of Empirical Application and Aggregation of a Linear Production Model), Area: 010, Lund University, Opponent: Fritz Holte, University of Oslo.

Jungenfelt, Karl (b. 1931), Löneandelen och den ekonomiska utvecklingen (The Wage Share and Economic Development), Area: 120, Stockholm University, Opponent: Björn Thalberg, Lund University.

\section{8}

Adler Karlsson, Gunnar (b. 1933), Western Economic Welfare 19471967. A Case Study in Foreign Economic Policy, Area: 050, Stockholm University (Faculty of Law), Opponent: Klaus Törnudd, University of Helsinki.

Carling, Alf (b. 1937), Industrins struktur och konkurrensförhållanden (SOU 1968:5) (Market Structure and Competititon in Swedish Industry), Area: 610, Lund University, Opponent: Preben Munthe, University of Oslo.

Eliasson, Gunnar (b. 1937), Kreditmarknader och industrins investeringar. En ekonometrisk studie av företagens kortsiktiga investeringsbeteende (Credit Markets and Industrial Investments. An Economic Study of the Short-run Investment Behaviour of Firms), Area: 610, Uppsala University, Opponent: Trygve Haavelmo, University of Oslo.

Hagström, Tony (b. 1936), Kreditmarknadens struktur och 
funktionssätt (SOU 1968:3) (The Structure and Operation of Credit Markets), Area: 310, Lund University, Opponent: Erik Dahmén, Stockholm School of Economics (HHS).

1969

Magnusson, Gudmundur (b. 1937), Production under Risk. A Theoretical Study, Area: 022, Uppsala University, Opponent: Tönu Puu, Uppsala University.

1970

Ribrant, Gunnar (b. 1936), Stordriftsfördelar inom industriproduktionen (SOU 1970:30) (Economies of Scale in Manufacturing), Area: 610, Stockholm University, Opponent: Erik Ruist, Stockholm School of Economics (HHS).

1972

Jonsson, Ernst (b. 1935), Kommunens finanser, Del I och II (Local Government Finance. Parts I and II), Area: 320, Stockholm School of Economics (HHS), Opponent: Bengt-Christer Ysander, Stockholm University.

1973

Vinell, Lars (b. 1935), Business Cycles and Steel Markets. Studies in Demand Variations and Firms' Short-term Behaviour in the Swedish Steel Market, Area: 630, Stockholm School of Economics (HHS), Opponent: Lars Nabseth, Jernkontoret.

NEW PH.D. DEGREES (1970-89)

\section{0}

Jacobsson, Lars (b. 1932), An Econometric Model of Sweden, Area: 130, Stockholm University, Opponent: Assar Lindbeck, HHS.

Mattsson, Bengt (b. 1940), Vägtrafikolyckornas samhällsekonomiska kostnader 1-3 (Economic Costs of Traffic Accidents 1-3), Area: 610, Gothenburg University, Opponent: Bengt-Christer Ysander, Stockholm University.

Wohlin, Lars (b. 1933), Skogsindustrins strukturomvandling och expansionsmöjlighet (The Prospects of Expansion and Structural 


\section{Appendix D}

Change in the Wood Industry), Area: 630, HHS, Opponent: Bertil Hållsten, University of Forestry.

1971

Bolin, Olof (b. 1941), Kapitalet i svenskt jordbruk (Real Capital in Swedish Agriculture), Area: 710, University of Agriculture, Opponent: Gunnar Eliasson, IUI.

Åberg, Carl Johan (b. 1930), Plan och prognos. En studie i de svenska långtidsutredningarnas metodik (SOU 1971:70) (Plan and Forecasting. A Study in the Methodology of Swedish Long-term Surveys), Area: 130, Stockholm University, Opponent: Gunnar Eliasson, IUI.

1972

Bergqvist, Leif (b. 1941), En aggregerad ekonometrisk modell av jordbruksnäringens ekonomi (An Aggregated Econometric Model of the Agricultural Sector), Area: 710, University of Agriculture, Opponent: F. Andersen, Copenhagen.

Dahlberg, Åke (b. 1945), Arbetsmarknadsutbildning - verkningar för den enskilde och samhället (Labour Market Training - Effects on the Individual and Society), Area: 810, Umeå University, Opponent: Ingemar Ståhl, Lund University.

Fredericks, Leo (b. 1941), Cooperative Structure and Government Policy in Malaysia, Area: 121, University of Agriculture, Opponent: Erich Jacoby.

Fridén, Lennart (b. 1935), Fluctuations in the International Steel Market 1953-1968: A Study of Import and Export Functions, Area: 630, HHS, Opponent: Karl Jungenfelt, HHS.

Grassman, Sven (b. 1940), Exchange Reserves and the Financial Structure of Foreign Trade. A Study in Commercial Capital Movements, Area: 430, Stockholm University, Opponent: William Branson, Princeton University.

Mäler, Karl-Göran (b. 1939), A Study in Environmental Economics, Area: 720, Stockholm University, Opponent: Ingemar Ståhl, Lund University.

Radetzki, Marian (b. 1936), Aid and Development. I: Principles and Methods. II: Problems of Application, Area: 440, HHS, Opponent: Staffan Burenstam Linder, HHS.

Rydén, Bengt (b. 1936), Fusioner $i$ svensk industri. En kartläggning och orsaksanalys av svenska industriföretags fusionsverksamhet 1946-69 (Mergers in Swedish Industry. A Survey and Causal 
Appendix D 213

Analysis of Swedish Industrial Firms), Area: 610, HHS, Opponent: Alf Carling, Stockholm University.

Wadensjö, Eskil (b. 1944), Immigration och samhällsekonomi. Immigrationens ekonomiska orsaker och effekter (Immigration and the Economy. Causes and Effects of Immigration), Area: 820, Lund University, Opponent: Tore Thonstad, Oslo.

Åkesson, Rolf (b. 1944), The Transfer Mechanism and the Foreign Debts of Low-income Countries, Area: 430, Lund University, Opponent: Göran Ohlin, Uppsala University.

1973

Jakobsson, Ulf (b. 1943) and Normann, Göran (b. 1942), Inkomstbeskattningen $i$ den ekonomiska politiken. En kvantitativ analys av systemet för personlig inkomstbeskattning 1952-1971 (Personal Income Taxation as a Part of Economic Policy. A Quantitative Analysis of the System for Personal Income Taxation), Area: 320, Lund University, Opponents: Ragnar Bentzel, Uppsala University and Lars Matthiessen, Stockholm School of Economics (HHS).

Matthiessen, Lars (b. 1930), A Study in Fiscal Theory and Policy, Area: 320, HHS, Opponent: Björn Thalberg, Lund University.

Meyerson, Per-Martin (b. 1927), Företagen och innovationerna: Studier $i$ den industriella förnyelsens betingelser (The Firms and the Innovations: Studies of the Conditions for Industrial Renewal), Area: 620, Stockholm University, Opponent: Alf Carling, Stockholm University.

Ohlsson, Lennart (b. 1942), Metallmanufakturindustrin. Produktionsförutsättningar och specialisering $i$ internationell jämförelse (SOU 1973:30) (The Metal Working Industry. An International Comparison of Production and Specialization), Area: 630, Uppsala University, Opponent: Per Magnus Wijkman, Stockholm University.

Skogh, Göran (b. 1943), Straffrätt och samhällsekonomi (Criminal Law and Economics), Area: 910, Lund University, Opponent: Bengt-Christer Ysander, Stockholm University.

\section{4}

Banks, Ferdinand (Fred) (b. 1928), The World Copper Market: An Economic Analysis, Area: 720, Uppsala University, Opponent: Lars Wohlin. IUI. 


\section{Appendix D}

Hannesson, Rögnvaldur (b. 1941), Economics of Fisheries: Some Problems of Efficiency, Area: 720, Lund University, Opponent: Jan Serck-Hansen, University of Oslo.

Söderström, Hans T:son (b. 1945), Studies in the Microdynamics of Production and Productivity Change, Area: 022, HHS, Opponent: Karl-Göran Mäler, HHS.

de Vylder, Stefan (b. 1945), Chile 1970-1973. The Political Economy of the Rise and Fall of the Unidad Popular, Area: 121, HHS, Opponent: Mogens Boserup, Copenhagen.

\section{5}

Cars, Hans Christian (b. 1939), Koncentrations- och fördelningsproblem inom marknadsekonomin (Problems of Concentration and Distribution in the Market Economy), Area: 610, Stockholm University, Opponent: Göran Eriksson, Stockholm University.

Eriksson, Göran (b. 1938), Företagens tillväxt och finansiering. Modeller över företagens beteende prövade på data från svenska verkstadsföretag (The Growth of Firms and Financing. Models of the Behaviour of Firms Tested on the Data for Swedish Engineering Companies), Area: 520, Stockholm University, Opponent: Hans Brems, University of Illinois, Urbana-Champaign.

Facht, Johan (b. 1941), Emission Control Costs in Swedish Industry. An Empirical Study of the Iron \& Steel and Pulp \& Paper Industries, Area: 720, HHS, Opponent: F. Reed Johnson, US Naval Academy, Annapolis.

Hjalmarsson, Lennart (b. 1944), Studies in a Dynamic Theory of Production and its Applications, Area: 022, Gothenburg University, Opponent: Björn Thalberg, Lund University.

Lundgren, Nils (b. 1936), Internationella koncerner i industriländer. Samhällsekonomiska aspekter (SOU 1975:50) (International Conglomerates in Industrialized Countries. Economic Aspects), Area: 440, Stockholm University, Opponent: Lars Wohlin, IUI.

Myhrman, Johan (b. 1937), Monetary Policy in Open Economies, Area: 023, Stockholm University, Opponent: S. Black, Harvard University.

Nyberg, Lars (b. 1945) and Viotti, Staffan (b. 1944), A Control Systems Approach to Macroeconomic Theory and Policy in an Open Economy, Area: 023, HHS, Opponents: William Branson, Princeton University and Björn Thalberg, Lund University.

Praski, Sverker (b. 1945), Econometric Investment Functions and an Attempt to Evaluate Investment Policy in Sweden 1960-1973, Area: 
Appendix D 215

520, Uppsala University, Opponent: Björn Thalberg, Lund University.

Rosengren, Björn (b. 1939), Valutareglering och nationell ekonomisk politik. En studie med anknytning till svenska erfarenheter åren 1959-1973 (Exchange Control and National Economic Policy. A Study Related to the Swedish Experience 1959-1973), Area: 430, Gothenburg University, Opponent: Preben Munthe, University of Oslo.

Siven, Claes-Henric (b. 1940), A Study in the Theory of Inflation and Unemployment, Area: 023, Stockholm University, Opponent: Tönu Puu, Umeå University.

Stuart, Charles (b. 1950), Search and the Organization of Marketplaces, Area: 920, Lund University, Opponent: Karl Borch, Norwegian School of Economics (Bergen).

Södersten, Jan (b. 1943), Profit Taxes and Resource Allocation, Area: 320, Uppsala University, Opponent: Lars Matthiessen, Odense.

Örtendahl, Per Anders (b. 1939), Substitutionsaspekter på produktionsprocessen vid massaframställning (Substitution in the Production of Pulp), Area: 630, Gothenburg University, Opponent: Finn Førsund, University of Oslo.

\section{6}

Andersson, Arne M. (b. 1925), Produktion, kapacitet och kostnader vid ett helautomatiskt emballageglasbruk (Production, Capacity, and Costs in a Fully Automated Glass Bottle Industry), Area: 630, Gothenburg University, Opponent: Åke Anderson, Gothenburg University.

Axell, Bo (b. 1945), Prices under Imperfect Information. A Theory of Search Market Equilibrium, Area: 021, Stockholm University, Opponent: Bengt-Christer Ysander, Stockholm University.

Fløystad, Gunnar (b. 1934), Studies in Distortions, Trade, and Allocation Problems, Area: 420, Gothenburg University, Opponent: Viktor Norman, Norwegian School of Economics (Bergen).

Franzén, Thomas, Lövgren, Kerstin and Rosenberg, Irma (b. 1945), Skatters och offentliga utgifters effekter på inkomstfördelningen. En teoretisk och empirisk studie (The Effects of Taxes and Public Expenditures in Income Distribution. A Theoretical and Empirical Study), Area: 320, Stockholm University, Opponents: Erik Höök, Jernkontoret, Per Meinich, Oslo and Hans Zeuthen, Århus.

Gustafsson, Siv (b. 1943), Lönebildning och lönestruktur inom den statliga sektorn (Determination and Structure of Salaries in the 


\section{Appendix $D$}

Government Sector in Sweden), Area: 820, HHS, Opponent: Olav Magnussen, Rogaland.

Gunnarsson, Jan (b. 1946), Produktionssystem och tätortshierarki om sambandet mellan rumslig och ekonomisk struktur (Production System and Hierarchy of Population Centres - on the Relation Between Spatial and Economic Structure), Area: 940, Gothenburg University, Opponent: Jan Serck-Hansen, University of Oslo.

Holmlund, Bertil (b. 1947), Arbetslöshet och lönebildning. Kvantitativa studier av svensk arbetsmarknad (Unemployment and Wage Formation. Quantitative Studies of the Swedish Labour Market), Area: 820, Umeå University, Opponent: Eskil Wadensjö, Lund University.

Ilstedt, Bruno (b. 1938), En analys av prisutvecklingen på den svenska exporten av pappersmassa samt papper och papp på Europamarknaden (An Analysis of Swedish Export Price Movements of Pulp, Paper and Cardboard to the European Market), Area: 720, University of Forestry, Opponent: Rolf Säter, University of Agriculture, Ås, Norway.

Jönsson, Bengt (b. 1944), Cost-Benefit Analysis in Public Health and Medical Care, Area: 910, Lund University, Opponent: Alan Williams, University of York.

Köstner, Evert (b. 1940), Optimal allokering av tid mellan utbildning och arbete (Optimal Allocation of Time Between Education and Employment), Area: 810, Gothenburg University, Opponent: Ingemar Ståhl, Lund University.

Lundberg, Lars (b. 1937), Handelshinder och handelspolitik. Studier av verkningar på svensk ekonomi (Barriers to Trade and Trade Policy. Studies of Effects on the Swedish Economy), Area: 420, Umeå University, Opponent: Ragnar Bentzel, Uppsala University.

Metuge, Enone (b. 1938), An Input-Output Study of the Structure and Resource Use in the Cameroon Economy, Area: 121, Lund University, Opponent: Laszlo Somogyi, Lund University.

Ohlsson, Olle (b. 1943), Substitution och odelbarheter i produktionsprocessen vid massaframställning (Substitution and Indivisibilities in the Production Process for Pulp Making), Area: 630, Gothenburg University, Opponent: Finn Førsund, University of Oslo.

Restad, Tomas (b. 1943), Modeller för samhällsekonomisk perspektivplanering (Models for Economic Perspective Planning), Area: 113, HHS, Opponent: Viktor Norman, Norwegian School of Economics, Bergen.

Spånt, Roland (b. 1944), Den svenska inkomstfördelningens utveckling (Changes in the Pattern of Swedish Income Distribution), 
Appendix D 217

Area: 820, Uppsala University, Opponent: Ulf Jakobsson, IUI.

Svensson, Lars E.O. (b. 1947), On Competitive Markets and Intertemporal Resource Allocation, Area: 021, Stockholm University, Opponent: Karl Vind, Copenhagen.

Wigren, Rune (b. 1942), Analys av regionala effektivitetsskillnader inom industribranscher. En teori med tillämpning på svenska förhållanden (An Analysis of Regional Differences in Efficiency within Industries. A Theory Applied to Swedish Conditions), Area: 630, Gothenburg University, Opponent: Finn Førsund, University of Oslo.

Wästlund, Jan (b. 1944), Skattning och analys av regionala effektivitetsskillnader inom industribranscher. Empiriska metoder med tonvikt på regiongrupperings- och aggregeringsproblem (Estimation and Analysis of Regional Differences in Efficiency Between Industries. Empirical Methods with an Emphasis on Regional Classification and Aggregation), Area: 630, Gothenburg University, Opponent: Arne Amundsen, University of Oslo.

1977

Bergman, Lars (b. 1945), Energy and Economic Growth in Sweden. An Analysis of Historical Trends and Present Choices, Area: 720, HHS, Opponent: Finn Førsund, Oslo.

Dahlberg, Lars (b. 1945), Empirical Studies in Public Planning, Area: 910, Gothenburg University, Opponent: Mervyn King, Cambridge University.

Hagén, Hans-Olof (b. 1946), Grafisk industri $i$ omvandling. En produktionsteknisk studie (Graphic Industry in Transition. A Study of Production Technology), Area: 630, Stockholm University, Opponent: Yngve Åberg, Stockholm University.

Hjalte, Krister (b. 1944), Sjörestaureringens ekonomi (An Economic Study of the Restoration of Lakes), Area: 720, Lund University, Opponent: Gunnar Bramness, University of Oslo.

Kruse, Agneta (b. 1944) and Ståhlberg, Ann-Charlotte (b. 1944), Effekter av ATP - en samhällsekonomisk studie (Effects of ATP An Economic Analysis), Area: 910, Lund University, Opponents: Jørn Henrik Pedersen, University of Odense and Nils Kellgren, Stockholm.

Löfgren, Karl-Gustaf (b. 1943), En studie $i$ neokeynesiansk arbetslöshets- och inflationsteori (A Study in Neokeynesian Unemployment and Inflation Theory), Area: 023, Umeå University, Opponent: Claes-Henric Siven, Uppsala University. 


\section{Appendix D}

Lönnroth, Johan (b. 1937), Marxism som matematisk ekonomi. En kritik av några moderna marxtolkningar (Marxism as Mathematical Economics. A Criticism of Several Modern Marxist Interpretations), Area: 210, Gothenburg University, Opponent: Leif Johansen, University of Oslo.

Sandelin, Bo (b. 1942), Prisutveckling och kapitalvinster på bostadsfastigheter (Price Development and Capital Gains in Housing Property), Area: 930, Gothenburg University, Opponent: BengtChrister Ysander, Stockholm University.

Svedberg, Peter (b. 1944), Foreign Investment and Trade Policies in an International Economy with Transnational Corporations. A Theoretical and Empirical Study with References to Latin America, Area: 420, Stockholm University, Opponent: B. Cohen, Yale University.

Svensson, Lars-Gunnar (b. 1942), Social Justice and Fair Distributions, Area: 025, Lund University, Opponent: Karl Vind, University of Copenhagen.

\section{8}

Becanovic, Tomislav (b. 1940), Central planering av produktion och utrikeshandel inom den sovjetiska skogsnäringen - En inputoutputanalytisk studie (Central Planning of Production and Foreign Trade in the Soviet Forestry Sector - An Input-Output Analysis), Area: 720, University of Forestry, Opponent: L. Folkesson, University of Agriculture.

Bruzelius, Nils (b. 1945), The Value of Travel Time. Theory and Measurement, Area: 025, Stockholm University, Opponent: Roland Andersson, Stockholm University.

Calmfors, Lars (b. 1948), Prices, Wages and Employment in the Open Economy, Area: 130, HHS, Opponent: Michael Bruno, Jerusalem.

Johansson, Börje (b. 1945), Contributions to Sequential Analysis of Oligopolistic Competition, Area: 022, Gothenburg University, Opponent: T. Smith, University of Pennsylvania.

Johansson, Per-Olov (b. 1949), Sysselsättning och samhällsekonomi. En studie av Algots etablering $i$ Västerbotten (Employment and the Economy. A Study of the Establishment of Algots in Västerbotten), Area: 820, Umeå University, Opponent: Bengt Mattson, Karlstad.

Lidgren, Karl (b. 1947), Dryckesförpackning och miljöpolitik - En studie av styrmedel (Beverage Containers and Environmental Policy), Area: 720, Lund University, Opponent: Harald Niklasson, University College of Växjö. 
Nilsson, Christian (b. 1941), Sysselsättning och arbetslöshet. En ekonometrisk analys av den svenska arbetsmarknadens funktionssätt 1964-1977 (Employment and Unemployment. An Econometric Analysis of the Operation of the Swedish Labour Market 1964-1977), Area: 820, Uppsala University, Opponent: Karl-Gustaf Löfgren, Umeå University.

Wells, Curt (b. 1942), Optimal Fiscal and Monetary Policy - Experiments with an Econometric Model of Sweden, Area: 130, Lund University, Opponent: David Livesey, Cambridge University.

1979

Andersson, Lars (b. 1946), Statens styrning av de kommunala budgeternas struktur (Central Government Influence on the Structure of the Municipal Budget), Area: 320, Gothenburg University, Opponent: Ulf Jacobsson, SAF.

Bigsten, Arne (b. 1947), Regional Inequality and Development. A Case Study of Kenya, Area: 121, Gothenburg University, Opponent: Erik Thorbecke, Cornell University.

Englund, Peter (b. 1950), Profits and Market Adjustment. A Study in the Dynamics of Production, Productivity and Rates of Return, Area: 022, HHS, Opponent: Lennart Hjalmarsson, Gothenburg University.

Gustafsson, Björn (b. 1948), Inkomst och uppväxtförhållanden (Income and Family Background), Area: 850, Gothenburg University, Opponent: Olav Magnussen, Rogaland University College.

Kanis, Alfred (b. 1940), Demand for Factors of Production. An Interrelated Model of Swedish Mining \& Manufacturing Industry, Area: 023, Stockholm University, Opponent: Ishaq Nadiri, New York.

Lundahl, Mats (b. 1946), Peasants and Poverty: A Study of Haiti, Area: 121, Lund University, Opponent: Christopher K. Clague, University of Maryland.

Markowski, Aleksander (b. 1946), A Formal Versus an Informal Forecasting Model. An Investigation of the Forecasting Procedure of the Swedish National Institute of Economic Research, Area: 130, Stockholm University, Opponent: Lars Vinell, HHS.

Persson, Mats (b. 1949), Inflationary Expectations and the Natural Rate Hypothesis, Area: 023, HHS, Opponent: Claes-Henric Siven, Stockholm University.

du Rietz, Gunnar (b. 1940), Företagsetableringarna i Sverige under 


\section{Appendix $D$}

efterkrigstiden (The Founding of Firms in Sweden in the Post-War Period), Area: 610, HHS, Opponent: Hans Söderström, Stockholm University.

Turner, Bengt (b. 1946), Hyressättning på bostadsmarknaden: Från hyresreglering till bruksvärdesprövning (Rent-setting: From Rent Regulation to Utility Value Regulation), Area: 930, Lund University, Opponent: Åke Andersson, Umeå University.

1980

Brown, Lorenzo (b. 1941), The Technical Representation of Returns to Scale on Cost and Production Functions, Area: 022, Stockholm University, Opponent: Peter Lloyd, Australian National University.

Hansson, Ingemar (b. 1951), Market Adjustment and Investment Determination: A Theoretical Analysis of the Firm and Industry, Area: 022, Lund University, Opponent: Staffan Viotti, Stockholm School of Economics (HHS).

Ivarson, Lars (b. 1940), Bankers portföljvalsbeteende. En teoretisk studie (The Portfolio Management Behaviour of Banks. A Theoretical Study), Area: 310, Umeå University, Opponent: Erkki Koskela, Helsinki.

Jansson, Jan Owen (b. 1939), Transport System Optimization and Pricing, Area: 610, HHS, Opponent: Ralph Turvey, ILO, Geneva.

Persson-Tanimura, Inga (b. 1945), Studier kring arbetsmarknad och information (Studies on Labour Markets and Information), Area: 820, Lund University, Opponent: Karl-Gustaf Löfgren, Umeå University.

Wibe, Sören (b. 1946), Teknik och aggregering i produktionsteorin. Svensk järnhantering 1850-1975. En branschanalys (Technology and Aggregation in the Theory of Production. Swedish Iron Industry 1850-1975. An Industry Analysis), Area: 630, Umeå University, Opponent: Finn Førsund, Oslo.

1981

Alberts, Tom (b. 1943), Agrarian Reform and Rural Poverty: A Case Study of Peru, Area: 121, Lund University, Opponent: R.M. Thorp, Oxford University.

Batten, Dave (b. 1947), Entropy, Information Theory and Spatial Input-Output Analysis, Area: 940, Umeå University, Opponent: Peter Nijkamp, Amsterdam (V.U. Free University). 
Bergström, Villy (b. 1938), Studies in Post-War Swedish Industrial Investments, Area: 520, Uppsala University, Opponent: Lars Mattiessen, Odense.

Björklund, Anders (b. 1950), Studies in the Dynamics of Unemployment, Area: 820, HHS, Opponent: Karl-Gustaf Löfgren, Umeå University.

Flam, Harry (b. 1948), Growth, Allocation and Trade in Sweden. An Empirical Application of the Heckscher-Ohlin Theory, Area: 410, HHS, Opponent: Lars Lundberg, Umeå University.

Granholm, Arne (b. 1942), Interregional Planning Models for the Allocation of Private and Public Investments, Area: 940, Gothenburg University, Opponent: Anders Karlquist, KTH.

Kling, Dick (b. 1945), Spridning av ny teknik. En analys av anpassningsprocesser $i$ svensk industri (The Diffusion of New Technology. An Analysis of Adaptive Behaviour in the Swedish Economy), Area: 620, Stockholm University, Opponent: Finn Førsund, Oslo.

Kristoffersson, Anders (b. 1947), Löntagarfonders finansiering och incidens (The Financing and Incidence of Wage Earner Funds), Area: 320, Uppsala University, Opponent: Karl Jungenfelt, Stockholm School of Economics (HHS).

Lindgren, Björn (b. 1942), Costs of Illness in Sweden 1964-1975, Area: 910, Lund University, Opponent: F. Jörgensen, University of Copenhagen.

Mattsson, Leif (b. 1947), Svenskt skogsutnyttjande och dess intresseperspektiv - en historisk belysning (Swedish Forest Utilization and Interest Groups: a Historical Perspective), Area: 720, University of Forestry, Opponent: Erik Bylund, Umeå University.

Murray, Richard (b. 1941), Kommunernas roll i den offentliga sektorn (The Role of Local Government in the Public Sector), Area: 320, Stockholm University, Opponent: Ingemar Ståhl, Lund University.

Ndlela, Daniel Boda (b. 1942), Dualism in the Rhodesian Colonial Economy, Area: 121, Lund University, Opponent: Arne Bigsten, Gothenburg University.

Sohlman, Åsa (b. 1938), Education, Labour Market and Human Capital Models. Swedish Experiences and Theoretical Analyses, Area: 850, Stockholm University, Opponent: Eskil Wadensjö, Stockholm University.

1982

Abril-Ojeda, Galo (b. 1945), The Role of Disaster Relief for Long- 


\section{Appendix D}

term Development in LDCs with Special Reference to Guatemala after the 1976 Earthquake, Area: 440, Stockholm University, Opponent: Amartya Sen, London.

Berg, Lennart (b. 1941), Konsumtion och sparande - en studie av hushållens beteende (Consumption and Savings - a Study of Household Behaviour), Area: 920, Uppsala University, Opponent: Ulf Jakobsson, SAF.

Bergendahl, Per Anders (b. 1947), Energi och ekonomi - Tillämpningar av input-output-analys (Energy and Economics - Applications of Input-Output Analysis), Area: 720, Gothenburg University, Opponent: O. Forsell, Uleåborg.

Buzaglo, Jorge (b. 1943), Planning Alternative Development Strategies. Experiments on the Mexican Economy, Area: 121, Stockholm University, Opponent: Åke Andersson, Umeå University.

Hansson, Göte (b. 1950), Social Clauses and International Trade. An Economic Analysis of Labour Standards in Trade Policy, Area: 420, Lund University, Opponent: Viktor Norman, Norwegian Scool of Economics (Bergen).

Hultkrantz, Lars (b. 1952), Skog för nutid och framtid - En samhällsekonomisk analys av det lämpliga virkesuttaget (Forests for the Present and the Future - An Economic Study of Optimal Felling), Area: 720, HHS, Opponent: Karl-Gustaf Löfgren, Umeå University.

Hårsman, Björn (b. 1943), Housing Demand Models and Housing Market Models for Regional and Local Planning, Area: 930, Umeå University, Opponent: Martin Paldam, Århus.

Juås, Birgitta (b. 1940), Värdering av risken för personskador. En jämförande studie av implicita och explicita värden (Valuation of the Risk of Personal Injuries. A Comparative Study of Implicit and Explicit Values), Area: 910, Gothenburg University, Opponent: Bengt Jönsson, Linköping University.

Kanafani, Noman (b. 1948), Oil and Development. A Case Study of Iraq, Area: 720, Lund University, Opponent: Rögnvaldur Hannesson, Bergen.

Lundborg, Per (b. 1950), Trade Policy and Development: Income Distributional Effects in the Less Developed Countries of the US and EEC Policies for Agricultural Commodities, Area: 420, Gothenburg University, Opponent: Irma Adelman, University of California at Berkeley.

Okowa, Willie J. (b. 1953), The Distributional Impact of Public Policy in Nigeria. A Dualistic Approach, Area: 121, Uppsala University, 
Opponent: Marian Radetzki, Stockholm University.

Palmer, Edward (b. 1945), Determination of Personal Consumption. Theoretical Foundations and Empirical Evidence from Sweden, Area: 200, Stockholm University, Opponent: Gunnar Eliasson, IUI.

Persson, Torsten (b. 1954), Studies of Alternative Exchange Rate Systems. An Intertemporal General Equilibrium Approach, Area: 410, Stockholm University, Opponent: Avinash Dixit, Princeton University.

Sundell, Björn (b. 1949), Ekonomiska studier av nytta och risk vid bekämpning av växtskadegörare (Economic Studies of the Utility and Risk of Pest-Control Methods in Agriculture), Area: 710, University of Agriculture, Opponent: M. Carlsson, University of Agriculture.

Wissén, Pehr (b. 1951), Wages and Growth in an Open Economy, Area: 220, HHS, Opponent: Ragnar Bentzel, Uppsala University.

1983

Blomström, Magnus (b. 1952), Foreign Investment, Technical Efficiency and Structural Change. Evidence from the Mexican Manufacturing Industry, Area: 440, Gothenburg University, Opponent: Richard Caves, Harvard University.

Bohman, Mats (b. 1939), Effektivitetsproblem inom vatten- och avloppområdet. En samhällsekonomisk studie av prissättning och nyinvesteringsinriktning (Efficiency Problems in Municipal Water and Sewage Works. An Economic Analysis of Pricing and Investments), Area: 720, Stockholm University, Opponent: Lennart Hjalmarsson, Gothenburg University.

Ekberg, Jan (b. 1942), Inkomsteffekter av invandring (Income Effects of Immigration), Area: 820, Lund University, Opponent: Bertil Holmlund, IUI.

Erzan, Refik (b. 1951), Turkey's Comparative Advantage, Production and Trade Patterns in Manufactures. An Application of the Factor Proportion Hypothesis with some Qualifications, Area: 410, Stockholm University, Opponent: Michael Michaely, Jerusalem.

Hedlund, Stefan (b. 1953), Crisis in Soviet Agriculture?, Area: 710, Lund University, Opponent: Alec Nove, Glasgow.

Holm, Magnus (b. 1941), Regionalekonomiska modeller för planering och samordning $i$ en decentraliserad ekonomi. Nagra teoretiska ansatser med tillämpningsexempel (Regional Economic Models for Planning and Coordination in a Decentralized Economy), Area: 940, Umeå University, Opponent: Ingolf Ståhl, HHS. 


\section{Appendix D}

Horn af Rantzien, Henrik (b. 1953), Imperfect Competition in Models of Wage Formation and International Trade, Area: 410, HHS, Opponent: Elhanan Helpman, Tel Aviv.

Larsson, Lars-Göran (b. 1941), Studies in Comparative Statics on the Basis of Optimization Methods, Area: 022, Gothenburg University, Opponent: Knut Sydsaeter, Oslo.

Persson, Håkan (b. 1949), Theory and Applications of Multisectoral Growth Models, Area: 110, Gothenburg University, Opponent: Cristopher Bliss, Oxford University.

Pålsson, Anne-Marie (b. 1951), Hushållen och kreditpolitiken. En studie av kreditrestriktioners effekt på hushållens konsumtion, sparande och konsumtionsmönster (Credit Policy and Households. A Study of the Effects of Credit Rationing on Household Consumption. Savings and Consumption Patterns), Area: 920, Lund University, Opponent: Claus Vastrup, University of Århus.

Rabinowicz, Ewa (b. 1948), En simuleringsmodell för svenskt jordbruk $i$ samspel med nationell och global ekonomi: produktion, konsumtion, utrikeshandel, politik (A Simulation Model of Swedish Agriculture and its Interaction with the National and Global Economy), Area: 710, SLU, Opponent: Søren KjeldsenKragh, Copenhagen School of Economics.

Soeria-Atmadja, Hillman (Sonny) (b. 1934), Product Guarantees and Liability Rules: An Economic Analysis, Area: 610, Stockholm University, Opponent: Frøstein Gjesdal, Norwegian School of Economics, Bergen.

\section{4}

Assarsson, Bengt (b. 1950), Inflation and Relative Prices in an Open Economy, Area: 023, Lund University, Opponent: Hans Genberg, Geneva.

Heikensten, Lars (b. 1950), Studies in Structural Change and Labour Market Adjustment, Area: 820, HHS, Opponent: Per-Olof Johansson, Umeå University.

Ingves, Stefan (b. 1953), Aspects of Trade Credit, Area: 410, HHS, Opponent: Lars Ivarsson, Umeå University.

Kajumulo-Tibaijuka, Anna (b. 1950), An Economic Analysis of Smallholder Banana-Coffee Farms in the Kagera Region Tanzania: Causes of Decline in Productivity and Strategies for Revitalization, Area: 710, University of Agriculture, Opponent: Philip Raikes, Denmark.

Lindskog, Dag (b. 1949), Foreign Disturbances and Domestic Reac- 
tions. A Comparative Study of Wage and Exchange Rate Policy Reactions in Denmark, Finland, Iceland and Sweden 1973-81, Area: 410, Stockholm University, Opponent: Ellen Andersen, University of Copenhagen.

Petersson, Lennart (b. 1942), Svensk utrikeshandel 1871-1980. En studie $i$ den intraindustriella handelns framväxt (Swedish Foreign Trade 1871-1980. A Study in the Growth of Interindustry Trade), Area: 420, Lund University, Opponent: Lars Lundberg, Umeå University.

Vedovato, Claudio (b. 1955), Politics, Foreign Trade and Economic Development in the Dominican Republic, Area: 121, Lund University, Opponent: H. Illy, Germany.

\section{5}

Bergström, Clas (b. 1950), Supply Disruptions and the Allocation of Emergency Reserves, Area: 720, HHS, Opponent: Partha Dasgupta, Cambridge.

Gottfries, Nils (b. 1952), Essays on Price Determination and Expectations, Area: 023, Stockholm University, Opponent: Alan Stockman, University of Rochester.

Karlström, Urban (b. 1953), Economic Growth and Migration During the Industrialization of Sweden. A General Equilibrium Approach, Area: 100, HHS, Opponent: Arne Bigsten, Gothenburg University.

Lindgren, Ragnar (b. 1936), On Capital Formation and the Effects of Capital Income Taxation, Area: 320, HHS, Opponent: Agnar Sandmo, Bergen.

Lundgren, Stefan (b. 1952), Model Integration and the Economics of Nuclear Power, Area: 210, HHS, Opponent: Steinar Strøm, Oslo.

Lyttkens, Carl-Hampus (b. 1955), Swedish Work Environment Policy: An Economic Analysis, Area: 910, Lund University, Opponent: Aanund Hylland, University of Oslo.

Nandakumar, Parameswar (b. 1950), Macroeconomic Effects of Supply Side Policies and Disturbances in Open Economies, Area: 130, Stockholm University, Opponent: Erling Steigum, Bergen.

Panas, Epaminondas (b. 1946), Almost Homogeneous Functions: A Theoretical and Empirical Analysis with Special Emphasis on Labour Input: The Case of Swedish Manufacturing Industries, Area: 630, Uppsala University, Opponent: Lennart Hjalmarsson, Gothenburg University.

Stenkula, Peter (b. 1942), Tre studier över resursanvändningen $i$ högskolan (Three Essays on Resource Allocation in the Swedish 


\section{Appendix D}

System of Higher Education), Area: 022, Lund University, Opponent: Ulf Lundgren, Stockholm University.

Tegle, Stig (b. 1947), Part-time Employment - An Economic Analysis of Weekly Working Hours in Sweden 1963-1982, Area: 810, Lund University, Opponent: Steinar Strøm.

Uhlin, Hans-Erik (b. 1944), Concepts and Measurement of Technical and Structural Change in Swedish Agriculture, Area: 710, University of Agriculture, Opponent: C.H. Hanf, Kiel University.

Vlachos, Vassilios (b. 1944), Temporära lönesubventioner. En studie av ett arbetsmarknadspolitiskt medel (Temporary Wage Subsidies. A Study of a Labour Market Policy Instrument), Area: 820, Lund University, Opponent: Anders Kristoffersson, Center for Working Life, Stockholm.

Ödegaard, Knut (b. 1939), Cash Crop versus Food Crop Production in Tanzania: An Assessment of the Major Post-Colonial Trends, Area: 710, Lund University, Opponent: Philip Raikes, Denmark.

\section{6}

Agell, Jonas (b. 1957), The Effects of Capital Taxation: An Equilibrium Asset Market Approach, Area: 320, Uppsala University, Opponent: Dale Jorgenson, Harvard University.

Atsé, David (b. 1952), Commodity Futures Trading and International Market Stabilization, Area: 410, Uppsala University, Opponent: Per Lundborg, FIEF, Stockholm.

Bjuggren, Per Olof (b. 1948), A Transaction Cost Approach to Vertical Integration: The Case of the Swedish Pulp and Paper Industry, Area: 630, Lund University, Opponent: Karl-Gustaf Löfgren, Umeå University.

Farm, Ante (b. 1943), A Model of the Price Mechanism, Area: 022, Stockholm University, Opponent: Hans Keiding, Århus University.

Flood, Lennart (b. 1952), On the Application of Time-Use and Expenditures Allocation Models, Area: 920, Gothenburg University, Opponent: Arie Kapteyn, Tilburg University.

Hörngren, Lars (b. 1954), On Monetary Policy and Interest Rate Determination in an Open Economy, Area: 023, HHS, Opponent: Sixten Korkman, Helsinki.

Kimei, Charles S. (b. 1953), Tanzania's Financial Experience in the Post-war Period, Area: 121, Uppsala University, Opponent: Arne Bigsten, Gothenburg University.

Kobba, Farouk (b. 1945), Foreign Investment Export Promotion and Economic Development. A Study of Macroeconomic Effects of 
Free Zone Manufacturing in Tunisia 1973-81, Area: 121, Stockholm University, Opponent: Karsten Laursen, Århus University.

Kumm, Karl-Ivar (b. 1945), Några ekonomiska studier inom jordbrukets miljövård (Economic Studies of Environment Protection in Agriculture), Area: 710, University of Agriculture, Opponent: Göran Widebeck, Lund University.

Papachristodoulou, Christos (b. 1955), Inventions, Innovations and Economic Growth in Sweden: An Appraisal of the Schumpeterian Theory, Area: 110, Uppsala University, Opponent: Gunnar Eliasson, IUI.

Schuller, Bernd-Joachim (b. 1940), Ekonomi och kriminalitet. En empirisk undersökning av brottsligheten $i$ Sverige (Crime and Economics. An Empirical Investigation of Delinquency in Sweden), Area: 910, Gothenburg University, Opponent: Göran Skogh, Lund University.

Sterner, Thomas (b. 1952), Energy Use in Mexican Industry, Area: 630, Gothenburg University, Opponent: Carol Dahl, Louisiana State University.

Wijkander, Hans (b. 1950), Indirect Corrections and Disequilibrium Pricing: Studies in Second-Best Policies, Area: 024, Stockholm University, Opponent: Roger Guesnerie, Paris.

Östblom, Göran (b. 1947), Structural Change in the Swedish Economy. Empirical and Methodological Studies of Change in InputOutput Structures, Area: 120, Stockholm University, Opponent: Finn Førsund, Oslo.

1987

Andersson, Krister (b. 1956) and Norrman, Erik (b. 1951), Capital Taxation and Neutrality. A Study of Tax Wedges with Special Reference to Sweden, Area: 320, Lund University, Opponent: Mats Persson, Stockholm University.

Bourdet, Yves (b. 1951), International Integration, Market Structure and Prices. A Case Study of the West-European Passenger Car Industry and Markets, Area: 630, Lund University, Opponent: Lars Lundberg, FIEF, Stockholm.

Brodin, Håkan (b. 1946), Regional Variations in Pharmaceutical Consumption in Sweden, Area: 913, Linköping University, Opponent: Kjeld Møller Pedersen, Odense.

Dargay, Joyce (b. 1948), Factor Demand in Swedish Manufacturing: Econometric analyses, Area: 630, Uppsala University, Opponent: 


\section{Appendix $D$}

Ernest Berndt, University of British Columbia.

Erixon, Lennart (b. 1947), Profitability in Swedish Manufacturing. Trends and Explanations, Area: 120, Stockholm University, Opponent: Sören Wibe, Umeå University.

Gunnarsson, Gudmundur (b. 1949), Ekonomiska tillväxten på Island 1910-80 - En produktivitetsstudie (Economic Growth in Iceland 1910-80 - A Study of Productivity), Area: 120, Uppsala University, Opponent: Gudmundur Magnusson, Reykjavik.

Lohmander, Peter (b. 1956), The Economics of Forest Management under Risk, Area: 720, University of Agriculture (Faculty of Forestry), Opponent: J. Risvand, Norway.

Norén, Ronny (b. 1951), Comparative Advantages Revealed. Experiments with a Quadratic Programming Model of Sweden, Area: 210, Stockholm University, Opponent: Börje Johansson, Umeå University.

Petersson, Jan (b. 1948), Erik Lindahl och Stockholmsskolans dynamiska metod (Erik Lindahl and the Dynamic Method of the Stockholm School), Area: 030, Lund University, Opponent: Hans Brems, University of Illinois, Urbana-Champaign.

Schager, Nils Henrik (b. 1944), Unemployment, Vacancy Durations and Wage Increases: Applications of Markov Processes to Labour Market Dynamics, Area: 120, Uppsala University, Opponent: Kenneth Burdett, Cornell University.

Stålhammar, Nils-Olov (b. 1953), Strukturomvandling, företagsbeteende och förväntningsbildning inom den svenska tillverkningsindustrin (Structural Changes, the Behaviour of Firms, and the Formation of Expectations in Swedish Manufacturing Industry), Area: 630, Gothenburg University, Opponent: Einar Hope, Norwegian School of Economics, Bergen.

Sundström, Marianne (b. 1950), A Study in the Growth of Part-Time Work in Sweden, Area: 810, Stockholm University, Opponent: Steinar Ström, Oslo.

Walfridson, Bo (b. 1946), Dynamic Models of Factor Demand. An Application to Swedish Industry, Area: 210, Gothenburg University, Opponent: Ishaq Nadiri, New York.

Westerberg, Ingvar (b. 1942), Produktion, produktivitet och kostnader $i$ svensk tandvård (Production, Productivity and Costs in Swedish Dental Care), Area: 913, Linköping University, Opponent: Björn Lindgren, Lund University. 
Appendix D 229

1988

Aguilar, Renato (b. 1943), Efficiency in Production: Theory and an Application on Kenyan Smallholders, Area: 710, Gothenburg University, Opponent: Rolf Färe, University of Southern Illinois.

Amid, Mohammad Javad (b. 1949), Land Reform and Rural Poverty in Iran: 1962-1978, Area: 710, Uppsala University, Opponent: Bo Gustafsson, Uppsala University.

Anderstig, Christer (b. 1947), Applied Methods for Analysis of Economic Structure and Change, Area: 220, Umeå University, Opponent: Roland Artle, University of California, Berkeley.

Anxo, Dominique (b. 1953), Sysselsättningseffekter av en allmän arbetstidsförkortning (Employment Effects of a Statutory Reduction in Working Hours), Area: 810, Gothenburg University, Opponent: Inga Persson, Lund University.

Bornmalm-Jardelöw, Gunilla (b. 1943), Högre utbildning och arbetsmarknad. En studie med tillämpningar på svenska förhållanden (Higher Education and the Labour Market. A Study with Applications to Sweden), Area: 850, Gothenburg University, Opponent: Bengt-Christer Ysander, Uppsala University.

Brännlund, Runar (b. 1957), The Swedish Roundwood Market. An Econometric Analysis, Area: 210, University of Agriculture, Faculty of Forestry, Opponent: Joseph Buongiorno, Madison, Wisconsin.

Edin, Per-Anders (b. 1957), Individual Consequences of Plant Closures, Area: 820, Uppsala University, Opponent: Barry McCormick, Southampton.

Ems, Emil (b. 1944), Economics of Public Information Systems, Area: 610, Stockholm University, Opponent: Ingemar Ståhl, Lund University.

Görling, Anders (b. 1950), Ekonomisk tillväxt och miljö. Föroreningsstruktur och ekonomiska effekter av olika miljövårdsprogram (Economic Growth and the Environment. The Structure of Pollution and the Economic Effects of Environmental Programs), Area: 720, Gothenburg University, Opponent: Finn Førsund, Oslo.

Karlsson, Charlie (b. 1945), Innovation Adoption and the Product Life Cycle, Area: 620, Umeå University, Opponent: Luc Soete, Maastricht.

Karlsson, Tohmas (b. 1953), A Macroeconomic Disequilibrium Model. An Econometric Study of the Swedish Business Sector 1970-84, Area: 210, Lund University, Opponent: Richard Quandt, Princeton University.

Kayizzi-Mugerwa, Steve (b. 1954), External Shocks and Adjustment 


\section{Appendix $D$}

in Zambia, Area: 121, Gothenburg University, Opponent: Peter Neary, Oxford University.

Kjellman, Sten (b. 1943), International Trade in Steam-coal, Area: 420, Stockholm University, Opponent: Lars Bergman, HHS.

Kuuluvainen, Jari (b. 1950), Nonindustrial Private Timber Supply and Credit Rationing. Microeconomic Foundations with Empirical Evidence from the Finnish Case, Area: 720, University of Agriculture, Faculty of Forestry, Opponent: C. Binkley, Yale University.

Lee, Barbara W. (b. 1955), Productivity and Employee Ownership: The Case of Sweden, Area: 610, Uppsala University, Opponent: Saul Estrin, London School of Economics.

Li, Chuanzhong (b. 1962), Mathematical Models in Forest Resource Management Planning. An Integrated Study of Calibration, Prediction and Optimal Decision Models, Area: 720, University of Forestry, Opponent: T. Burke, St. Paul University, Minnesota.

Mbelle, Ammon (b. 1954), Foreign Exchange and Industrial Development: A Study of Tanzania, Area: 121, Gothenburg University, Opponent: Finn Førsund, Oslo.

Ohlsson, Henry (b. 1956), Cost-Benefit Analysis of Labor Market Programs. Applied to a Temporary Program in Northern Sweden, Area: 820, Umeå University, Opponent: Eskil Wadensjö, Stockholm University.

Ongaro, Wilfred (b. 1953), Adoption of New Farming Technology. A Case Study of Maize Production in Western Kenya, Area: 710, Gothenburg University, Opponent: Paul Collier, Oxford University.

Sarafoglou, Nikias (b. 1954), A Contribution to Population Dynamics in Space, Area: 840, Umeå University, Opponent: Walter Isard, Cornell University.

Sardelis, Christopher (b. 1950), Local Employment Policy. A Study on the Properties of Intermunicipal Rivalry, Area: 820, Stockholm University, Opponent: Ingolf Ståhl, HHS.

Vargas-Lundius, Rosemary (b. 1953), Peasants in Distress. Poverty and Unemployment in the Dominican Republic, Area: 121, Lund University, Opponent: Claudio Gonzalez-Vega, Ohio State University.

Wernerheim, Michael C. (b. 1953), The Economic Control of a Renewable Resource Under Sole Ownership, Area: 720, Uppsala University, Opponent: Rögnvaldur Hannessen, Norwegian School of Economics (Bergen).

Vredin, Anders (b. 1957), Macroeconomic Policies and The Balance of Payments, Area: 023, HHS, Opponent: Hans Genberg, Geneva. 
Zejan, Mario (b. 1951), Studies in the Behavior of Swedish Multinationals, Area: 440, Gothenburg University, Opponent: Sanjaya Lall, Oxford University.

\section{9}

Andersson, Irene (b. 1950), Familjebeskattning, konsumtion och arbetsutbud. En ekonometrisk analys av löne- och inkomstelasticiter för svenska hushåll (Family Taxation, Consumption and Labour Supply. An Econometric Analysis of Wage and Income Elasticities in Swedish Households), Area: 810, Gothenburg University, Opponent: David Brownstone, University of California at Irvine.

Andersson, Thomas (b. 1959), Foreign Direct Investment in Competing Host Countries, Area: 440, HHS, Opponent: James Markusen, University of Western Ontario.

Andreasson, Ing-Marie (b. 1951), Costs of Controls on Farmers' Use of Nitrogen. A Study Applied to Gotland, Area: 720, HHS, Opponent: Jon Strand, Oslo.

Axelsson, Roger (b. 1944), Svensk arbetsmarknadsutbildning. En kvantitativ analys av dess effekter (Swedish Manpower Training - a Quantitative Analysis of its Effects), Area: 810, Umeå University, Opponent: Anders Björklund, Stockholm University.

Behar, Jaime (b. 1938), Trade and Employment in Mexico, Area: 420, Stockholm University, Opponent: Arne Bigsten, Gothenburg University.

Dresdner C., Jorge D. (b. 1957), The Structuralist Theory of Inflation and Structural Inflation in Chile, 1950-1972: The Lagging Food Hypothesis Revisited, Area: 130, Uppsala University, Opponent: Martin Paldam, University of Århus.

Eidem, Rolf (b. 1943), Aktieägandet och demokratin. Ägarfrågan från brukssamhälle till kompetenskapitalism (Shareholding and Democracy. The Issue of Ownership from the Industrial Local Community to the Capitalism of Competence), Area: 050, HHS, Opponent: Eskil Wadensjö, Stockholm University.

Hansson, Pär (b. 1957), Intra-Industry Trade. Measurements, Determinants and Growth - A Study of Swedish Foreign Trade, Area: 410, Umeå University, Opponent: David Greenaway, Nottingham.

Lindh, Yngve (b. 1949), Price Determination in Swedish Manufacturing: Theory and Evidence, Area: 600, Uppsala University, Opponent: Göran Eriksson, Stockholm University. 


\section{Appendix $D$}

Löfström, Åsa (b. 1948), Diskriminering på svensk arbetsmarknad. En analys av löneskillnader mellan kvinnor och män (Discrimination in the Swedish Labour Market - An Analysis of Wage Differences Between Men and Women), Area: 820, Umeå University, Opponent: Inga Persson, Lund University.

Tansini, Ruben (b. 1953), Technology Transfer: Dairy Industries in Sweden and Uruguay, Area: 630, Gothenburg University, Opponent: Finn Førsund, Oslo.

Zhang, Wei-Bin, Theory of Economic Development - Nonlinearity, Instability and Non-equilibrium, Area: 110, Umeå University, Opponent: Michio Morishima, LSE. 


\section{Notes and references}

\section{POINTS OF DEPARTURE}

\section{Notes}

1 Peter H. Rossi, in a Foreword to Chen (1990:7), goes so far as to say that evaluation research today constitutes 'the most exciting career a young social scientist may embark on'.

2 Another government body holding such responsibility is the Office of Swedish Higher Education.

3 The existence of such a core, which gradually becomes shielded by a protective belt, is often considered an advantage. Hull (1988:515) points out, however, that 'the protective belt that surrounds the most fundamental tenets of any scientific research program can become so protective that nothing can possibly penetrate it'. And he continues: 'The adherents of ideologies cease serious testing.'

4 Note, however, that Collander also points out that 'economics is tied together not by a common set of questions but by a common set of techniques'. This last led Ysander (1990:101) to describe economics 'as a method for analysis continuously hunting for new problems and areas of application' (our translation). According to March and Olsen (1976) this is not a rare phenomenon in modern organizations.

5 The problems involved in applying such a focused allocation strategy have been pointed out by the French economist Edmond Malinvaud (1985:183) as follows: 'It seems to me that the distribution of resources among economic research areas hardly ever achieved what was intended; fortunately, it was often diverted to the benefit of spontaneous and unpredictable imaginative efforts in related areas.'

6 Cf. Georghiou (1989:17), where a distinction is made between three main groups of actors in evaluations: those being evaluated, those performing the evaluation, and the audience of the evaluation.

7 It could of course be argued that an important input to the research system consists of the education of undergraduates. However, it was considered to fall outside the task of the present evaluation project.

8 The growing interest within the economics profession in the development of the discipline bears witness to this (cf. e.g. Hey and Winch 1990, Jonung 1991a, Sandelin 1991). 


\section{Notes and references}

9 This will be a particularly urgent problem during the 1990s, since in most industrialized countries universities went through a period of rapid expansion in the late 1960s and early 1970s. Replacements will therefore be needed for the many university teachers who will be retiring during the coming decades (Ds 1989:43).

10 The importance of evaluating the training of future scientists is emphasized in Anderson (1989). The author finds it surprising that this activity has largely escaped the kind of systematic, quantitative analysis now being applied to other components of national science systems' (Anderson 1989:93).

11 It may be noted that no efforts have been made to explicitly relate the different output measures to input measures. The two main reasons for this position are the multi-goal character of research and the measurement problems involved in such an exercise.

12 Our selection procedure excludes economic history from the study, since in Sweden this subject is taught in separate departments (cf. further below in Chapter 2). The bibliometric analysis in Chapter 5 also indicates some borderline problems in relation to business administration. However, neither of these seems to influence the general conclusions.

13 The editor of the present volume, who at the time was chairman of the HSFR sub-committee for economic sciences, was given the task of heading the evaluation team.

14 Our situation seems to have resembled that described by Chen (1990:79), i.e. the number of stakeholders was limited and there was little disagreement. Under these circumstances Chen claims that 'open discussion will usually enable [stakeholders] to effectively reach agreement and allow the evaluators to create a workable design for conducting the evaluation.'

15 Not only was this felt to be appropriate by the international evaluation group, but the procedure had also been suggested as a general rule for all evaluations by the Swedish Association of University Teachers (SULF) in a letter to the Research Councils dated 5 April 1989.

16 Cf. Luukkonen-Gronow (1989b): 'The use of peer evaluation teams is expensive and requires a commitment in time from all parties involved.'

17 Jonung's approach appears to have come naturally in other disciplines too (cf. Carlson 1980). Further discussion of the work of the earlier Swedish economists can be found in Sandelin (1991).

18 Many of these, such as HSFR and the Bank of Sweden Tercentenary Foundation, base their decisions on peer reviews in the same way as similar bodies in some other countries such as the United States (cf. Newlon 1989) and Germany (cf. Neidhardt 1988). However, there are also examples of what Hill (1989:223) calls 'pork-barrel science', i.e. 'the allocation of [ . . ] government money without scientific peer review to specific facilities and activities'. The present trend seems to be towards increasing the importance of the peer review (cf. e.g. Elzinga 1988:10).

19 Cf. Engwall (1992:6), Swedberg (1988a) and Zetterblom (1986).

20 Such remarks spring from the fear that bibliometrics neglects work presented in monographs or in minority languages. There is also anxiety that too heavy an emphasis on article publications may hamper long-term and/or risky research projects.

21 This also means that we can follow the advice of van Raan (1989:181), for instance, by providing an opportunity for interaction 'between the data 
provided by [bibliometric] indicators and background knowledge'. Cf. also Anderson (1989).

22 Although they did not publish journal articles as much as their successors are doing, even the older generation of Swedish economists made a remarkable international impact. The experience of one of the evaluators, Robert M. Solow, is illustrative: 'Strangely enough, for an American, I was at that time [early 1950s] more familiar with the writings of the Swedish economists than with Keynes or the immediate English Keynesians. Somewhere in graduate school I had read Lindahl, Myrdal, Ohlin, Lundberg, and most especially Wicksell. Those books are still on my shelves' (Solow 1990:191.)

23 Note that this was written before the explosive expansion of the fax machine and electronic mail.

24 According to Lovell (1973:27-9) the output of economic articles between 1886 and 1965 more or less doubled every fourteenth year. This was remarkably close to earlier estimates for chemistry, biology, physics and mathematics, for which the corresponding figure was fifteen years. In connection with this tendency towards growth Kindleberger (1989:43-4) commented: 'A century ago an economist would have been in touch with the ideas of all his or her peers through reading their books, combining a limited number of journals, and conducting correspondence. As economic literature grew exponentially [. . . and] as the explosion exfoliated [. . . ] it quickly became impossible to keep up even with what was being written in one's specialty.'

25 As Kodama (1989:31) has pointed out, this immobility constitutes a special problem in evaluation, since it means that 'researchers have to continue to work in the same organization, even if they receive a bad score'.

$26 \mathrm{Cf}$. the problem in business concerning the control of auditors.

27 Cf. Alkin (1990:19): 'Utilization begins the first day of an evaluation project. Important kinds of evaluation - frequently the most important occur during the process of planning and implementing an evaluation, not simply with the delivery of a final report.'

28 It is of course vital to any evaluation that the information it provides is actually considered. But it seems to be going a bit far to say as Alkin (1990:20) does that an evaluation has not occurred unless its information is considered.

29 Cf. also McCloskey (1990:8): 'Science is rhetoric, human argument, all the way down.'

30 This idea also lies behind Guba and Lincoln's description of fourth generation evaluation, which "begins with the assumption that realities are not objectively defined "out there" but are constructed by people, often under the influence of variety of social and cultural factors that lead to shared constructions' (Guba and Lincoln 1989:12). They point out accordingly that negotiations between evaluators and stakeholders constitute an important part of modern evaluation practice (cf. above).

31 For a discussion of this interplay between scientific work and context, see also Latour (1987).

32 According to Pencavel (1991) we should expect institutional constraints to be particularly important in this process. 


\section{Notes and references}

33 That the effects in such cases may not be exclusively positive has been pointed out by Elzinga (1988) among others.

34 Cf. Friedman (1990), who demonstrates his thesis in a review of past issues of the Economic Journal. Among other things he refers to the increasing use of mathematics, which he feels would make most modern articles unreadable by authors who have contributed to earlier volumes. Malinvaud (1985:172) had previously made a similar point: 'Editors of journals often wonder whether they should accept mathematically correct articles whose significance for economic theory is difficult to access.'

35 McCloskey's remedy to this is that economics should be 'shown to be fictional and poetical and historical'. Thus he claims that 'the economist's story will become, as it should, a useful comedy - comprising words of wit, amused tolerance for human folly, stock characters colliding at last in the third act, and most characteristic of the genre, a universe in equilibrium and a happy ending' (McCloskey 1990:162).

\section{References}

Alchian, A. A. and Demsetz, H. (1972) 'Production, Information Costs, and Economic Organization', American Economic Review, 62, December:77795.

Alkin, M. C. (ed) (1990) Debates on Evaluation, London: Sage.

Allardt, E., Lysgaard, S. and Bøttger Sørensen, A. (1988) Sociologin i Sverige (Sociology in Sweden), Uppsala: Swedish Science Press.

Anderson, J. (1989) 'The Evaluation of Research Training', in D. Evered and S. Harnett (eds) The Evaluation of Scientific Research, Chichester: Wiley: 93-119.

Argyris, C. and Schön, D. A. (1978) 'Organizational Learning', in C. Argyris and D. A. Schön Organizational Learning: A Theory of Action Perspective, Reading, MA: Addison-Wesley: 8-29.

Bentzel, R. (1986) 'Nationalekonomi och ekonomisk historia' (Economics and Economic History), in Juridisk och samhällsvetenskaplig forskning, UHÄrapport 1986:25:85-101.

Berger, P. L. and Luckmann, T. (1966) The Social Construction of Reality: A Treatise in the Sociology of Knowledge, Garden City, NY: Doubleday.

Blaug, M. (1980) The Methodology of Economics. or How Economists Explain, Cambridge: Cambridge University Press.

Blume, S. (1989) 'Contribution to the General Discussion II: Beyond Bibliometrics', in: D. Evered and S. Harnett (eds) (1989) The Evaluation of Scientific Research, Chichester: Wiley:217.

Bromley, D. A. (1972) Physics in Perspective, Washington, DC: National Academy of Sciences.

Caldwell, B. J. (1982) Beyond Positivism: Economic Methodology in the Twentieth Century, London: Allen \& Unwin.

Carlson, S. (1980) 'Tidigare svensk företagsekonomi' (Early Swedish Business Administration), in L. Engwall (ed.) Företagsekonomins rötter, Lund: Studentlitteratur: $28-40$.

Chen, H.-T. (1990) Theory-Driven Evaluations, Newbury Park, CA: Sage.

Coats, A. W. and Colander, D. (1989) 'An Introduction to the Spread of 
Economic Ideas', in D. C. Colander and A. W. Coats (eds) The Spread of Economic Ideas, Cambridge: Cambridge University Press: 1-19.

Clower, R. W. (1989) 'The State of Economics: Hopeless but not Serious?', in D. C. Colander and A. W. Coats (eds) The Spread of Economic Ideas, Cambridge: Cambridge University Press: 23-9.

Colander, D. (1989a) 'The Invisible Hand of Truth', in D. C. Colander and A. W. Coats (eds) The Spread of Economic Ideas, Cambridge: Cambridge University Press: 31-6.

Cook, T. D. and Campbell, D. T. (1979) Quasi-Experimentation: Design and Analysis Issues for Field Settings, Chicago: Rand McNally.

Danielsen, R. et al. (1988) Historia; belsuing (History in the light), Uppsala: Swedish Science Press.

DiMaggio, P. J. and Powell, W. W. (1983) 'The Iron Cage Revisited: Institutional Isomorphism and Collective Rationality in Organizational Fields', American Sociological Review, 48, 2:147-60.

Ds 1989:43, Forskningens villkor $i$ omvärlden (The Conditions of Research Outside Sweden), Stockholm: Allmanna förlaget.

Eliassen, K. A. and Pedersen, M. N. (1984) Svensk samhällsorganisation och förvaltning. En inventering av svensk forskning (Swedish Social Organization and Public Administration. An Inventory of Swedish Research), Stockholm: HSFR.

Elzinga, A. (1988) 'The Consequences of Evaluation for Academic Research', Science Studies, 1, December:5-14.

Engwall, L. (forthcoming) Mercury Meets Minerva, London: Pergamon Press.

Fama, E. and Jensen, M. (1983) 'Separation of Ownership and Control', Journal of Law and Economics, 26, June:301-25.

Friedman, M. (1991) 'Old Wine in New Bottles', Economic Journal, 101, January:33-40.

Georghiou, L. G. (1989) 'Organization of Evaluation', in D. Evered and S. Harmett (eds) The Evaluation of Scientific Research, Chichester: Wiley: 1626.

Government Bill 1981/82:106.

Graves, P. E., Marchand, J. R. and Thompson, R. (1982) 'Economics Departmental Rankings: Research Incentives, Constraints, and Efficiency', American Economic Review, 72, December:1131-41.

Guba, E. G. and Lincoln, Y. S. (1989) Fourth Generation Evaluation, Newbury Park, CA: Sage.

Hăgg, I. (1979) 'Reviews of Capital Investments: Empirical Studies', Finnish Journal of Business Economics, 28, 3:211-25.

Hey, J. D. and Winch, D. (1990) A Century of Economics: 100 Years of the Royal Economic Society and the Economic Journal, Oxford: Basil Blackwell.

Hill, C. T. (1989) 'How Science Policies are Determined in the United States', in D. Evered and S. Harnett (eds) (1989) The Evaluation of Scientific Research, Chichester: Wiley: 221-33.

Hirsch, B. T., Austin, R., Brooks, J. and Moore, J. B. (1984) 'Economics Departmental Rankings: Comment', American Economic Review, 74, September:822-6.

Hull, D. L. (1988) Science as a Process. An Evolutionary Account of the 


\section{Notes and references}

Social and Conceptual Development of Science, Chicago: University of Chicago Press.

Irvine, J. (1989) 'Evaluation of Scientific Institutions: Lessons from a Bibliometric Study of UK Technical Universities', in D. Evered and S. Harnett (eds) (1989) The Evaluation of Scientific Research, Chichester: Wiley: 141-68.

Jonung, L. (ed.), (1991a) The Stockholm School of Economics Revisited, Cambridge: Cambridge University Press.

Jungenfelt, K. G. and Lindbeck, A. (1973) 'Economic Research in Sweden During the Post-war Period', in Social Science Research in Sweden, Stockholm: Scandinavian University Books: 9-22.

Kimberly, J. R. et al. (1980) The Organizational Life Cycle, San Fransisco: Jossey-Bass.

Kindleberger, C. P. (1989) 'How Ideas Spread Among Economists: Examples from International Economics', in D. C. Colander and A. W. Coats (eds) The Spread of Economic Ideas, Cambridge: Cambridge University Press: 43-59.

Klamer, A., McCloskey, D. N. and Solow, R. M. (eds) (1988) The Consequences of Economic Rhetoric, Cambridge: Cambridge University Press.

Kodama, F. (1989) 'Contribution to the Discussion', in D. Evered and S. Harnett (eds) (1989) The Evaluation of Scientific Research, Chichester: Wiley: 31.

Kuhn, T. S. (1962) The Structure of Scientific Revolutions, Chicago: Chicago University Press.

Lakatos, I. (1978) The Methodology of Scientific Research Programmes. Philosophical Papers. Vols 1-2, Cambridge: Cambridge University Press.

Landgren, K.-G. (1957) Economics in Modern Sweden, Washington: Library of Congress (Translation from the Swedish by Paul Gekker).

Latour, B. (1987) Science in Action, Milton Keynes: Open University Press.

Lincoln, Y. S. and Guba, E. G. (1985) Naturalistic Inquiry, Beverly Hills, CA: Sage.

Lodahl, J. B. and Gordon, G. (1972) 'The Structure of Scientific Fields and the Functioning of University Graduate Departments', American Sociological Review, 37, February:57-72.

Lodge, D. (1985) Small World, Harmondsworth, Middlesex: Penguin (first published by Martin Secker \& Warburg in 1984).

Lovell, M. C. (1973) 'The Production of Economic Literature: An Interpretation', Journal of Economic Literature, 11, 1:27-55.

Luukkonen-Gronow, T. (1989a) 'The Impact of Evaluation Data on Policy Determination', in D. Evered and S. Harnett (eds) (1989) The Evaluation of Scientific Research, Chichester: Wiley: 234-46.

- (1989b) "Contribution to the General Discussion II: Beyond Bibliometrics', in D. Evered and S. Harnett (eds) (1989) The Evaluation of Scientific Research, Chichester: Wiley: 216.

McCloskey, D. N. (1983) 'The Rhetoric of Economics', Journal of Economic Literature, 21, June:481-517.

- (1986) The Rhetoric of Economics, Brighton: Wheatsheaf.

(1990) If You're so Smart. The Narrative of Economic Expertise, Chicago: Chicago University Press.

Malinvaud, E. (1985) 'The Identification of Scientific Advances in Economics', in T. Hägerstrand (ed.), The Identification of Progress in Learning, Cambridge: Cambridge University Press: 167-83. 
- (1991) 'The Next Fifty Years', Economic Journal, 101, January:64-8.

March, J. G. and Olsen, J. P. (1976) Ambiguity and Choice in Organizations, Bergen: Universitetsforlaget.

Mitroff, I. (1974) The Subjective Side of Science. A Philosophical Inquiry into the Psychology of the Apollo Moon Scientists, Amsterdam: Elsevier.

Narin, F. (1987) 'Bibliometric Techniques in the Evaluation of Research Programs', Science and Public Policy, 14, 2:99-106.

Neidhardt, F. (1988) Selbststeuerung in der Forschungsförderung. Das Gutachterwesen der DFG, Opladen: Westdeutscher Verlag.

Newlon, D. H. (1989) 'The Role of NSF in the Spread of Economic Ideas', in D. C. Colander and A. W. Coats (eds), The Spread of Economic Ideas, Cambridge: Cambridge University Press: 195-228.

NFR (1981) 'International Evaluations of Research Projects Supported by the Swedish Natural Science Research Council. Summary of Reports, Achievements and Criticisms, 1977-1980', Stockholm: Swedish Natural Science Research Council.

Pasinetti, L. (1985) 'Comment on E. Malinvaud's Paper', in T. Hägerstrand (ed.), The Identification of Progress in Learning, Cambridge: Cambridge University Press: 183-6.

Pedersen, K. M. (1977), 'A Proposed Model for Evaluation Studies', Administrative Science Quarterly, 22, June:306-17.

Pencavel, J. (1991) 'Prospects for Economics', Economic Journal, 101, January:81-7.

Phillips, D. (1989) 'Contribution to the General Discussion II: Beyond Bibliometrics', in D. Evered and S. Harnett (eds) (1989) The Evaluation of Scientific Research, Chichester: Wiley: 215.

Portes, R. (1987) 'Economics in Europe', European Economic Review, 31, August:1329-40.

Puu, T. (1990) 'Några reflexioner över nationalekonomin idag' (Some Reflections on Economics Today), in K. Fridjonsdottir (ed.), Svenska samhällsvetenskaper (Swedish Social Sciences), Stockholm: Carissons: 109-12.

Sandelin, B. (ed.) (1991) The History of Swedish Economic Thought, London: Routledge.

Solow, R. (1990) 'My Evolution as an Economist', in W. Breit and R. W. Spencer (eds), Lives of the Laureates, Cambridge, MA: MIT Press.

Stigler, G. J. (1982) The Economist as Preacher and Other Essays, Chicago: Chicago University Press.

- (1984) 'Economics - The Imperial Science?', Scandinavian Journal of Economics, 86, 3:301-13.

Swedberg, R. (1988a) 'De nya doktorsavhandlingarna i sociologi 1969-1986' (The New Doctoral Theses in Sociology 1969-1986), in E. Allardt, S. Lysgaard and A. Bøttger Sørensen (1988) Sociologin i Sverige (Sociology in Sweden), Uppsala: Swedish Science Press: 144-79.

van Raan, A. F. J. (1989) 'Evaluation of Research Groups', in D. Evered and S. Harnett (eds) (1989) The Evaluation of Scientific Research, Chichester: Wiley: $169-87$.

Weinberg, A. M. (1963) 'Criteria for Scientific Choice', Minerva, 1, 2:159-71.

Ysander, B.-C. (1990) 'Varför är nationalekonomer så högfärdiga? Särdrag, problem och utvecklingsmöjligheter i svensk nationalekonomisk forskning' (Why are Economists so Stuck-Up? Distinguishing Features, Problems and 


\section{Notes and references}

Opportunities for Development in Swedish Economic Research), in K. Fridjonsdottir (ed.), Svenska samhällsvetenskaper (Swedish Social Sciences), Stockholm: Carlssons: 99-108.

Zetterblom, G. (1986) 'Postgraduate Education in Sweden: Reforms and Results', European Journal of Education, 21, 3:261-73.

\section{ECONOMICS THE SWEDISH WAY 1889-1989}

\section{Notes}

1 I have benefited from comments by Hans Brems, Lars Calmfors, Benny Carlsson, Lars Engwall, Bent Hansen, Björn Hansson, Hugo Hegeland, Magnus Henrekson, Peter Högfelt, Assar Lindbeck, Axel Leijonhufvud, Mats Persson, Bo Sandelin, Charles Stuart, Ingemar Ståhl, Lars E. O. Svensson, Lance Taylor, Eskil Wadensjö, Torbjörn Vallinder, Kumara Velupillai, Lars Werin and seminar participants at the Stockholm School of Economics and the Department of Economics at Lund University as well as from interviews held earlier with Bertil Ohlin, Gunnar Myrdal, Karin Kock, Johan Åkerman, Karl-Gustav Landgren and Erik Lundberg in connection with my work on the Swedish interwar period.

I owe a great debt to Eskil Wadensjö for detailed comments on several versions of this report, and to Elving Gunnarsson for helping me to compile tables and charts and for gathering background material. Lucy Loerzer and Nancy Adler have given me valuable linguistic guidance.

2 I am aware of the difficulties in presenting a balanced picture. This account has been influenced by my work on the founding fathers of Swedish economics, in particular Knut Wicksell, and on the Stockholm School, as well as on Swedish economic policy and debate since the Second World War. (Cf. e.g. Jonung, 1990a, 1990b, 1991a and 1991b and references therein.)

3 With apologies to Karin Kock, the only woman to have held the title of professor in economics in Sweden, I use 'he' as a synonym for professor.

4 My emphasis on the extramural activities of Swedish professors does not imply an endorsement of this pattern at the expense of research. But since earlier reports such as Landgren (1957) and Jungenfelt and Lindbeck (1973) have concentrated on the research carried out by professors, consequently paying less attention to their other pastimes, I feel it would be appropriate to look here at professorial extramural activities.

5 The chair was designed to include sociology as a way of preventing Gustav Cassel from applying for it. At that time Cassel was considered too radical - a remarkable view considering Cassel's later position as Sweden's leading conservative economist.

6 The first chairs exclusively in economics in the state university system were established at Lund and Uppsala in 1947.

7 Steffen played a minor role in this context. He turned to sociology and politics and left no lasting mark on Swedish economics. He was very active in the public debate, however, among other things as a member of Parliament.

8 Davidson published 234 articles and 15 reviews in Ekonomisk Tidskrift.

9 Wicksell was quite pessimistic about his future prospects in Sweden; his reputation as a radical and the fact that he was older than Davidson 
restricted his chances of winning the second chair in the country, at Lund, where the current holder, Professor Gustaf Hamilton, showed no sign of retiring. Wicksell even considered going to Germany to enquire about a position shortly before he was given the temporary chair in Lund. It is interesting to speculate what might have happened to Swedish economics if he had left Sweden permanently.

10 Of these three Emil Sommarin was the most active; his research focused on economic history.

11 On this point, see contributions by Earlene Craver and Eskil Wadensjö in Jonung (1991a) and by Wadensjö in Jonung (1991b).

12 On this point, see the introduction to Jonung (1990a) and Sandelin (1991).

13 Table 2.3 is a very rough summary. It does not include, for example, the pioneering work of Herman Wold in the field of economics and statistics, as Wold never held a chair in economics.

14 In Great Economists since Keynes (Blaug 1985), which includes 100 prominent economists, three Swedes are included: Axel Leijonhufvud, Gunnar Myrdal and Bertil Ohlin. The second two have both died, and their impact belongs to the interwar period. Symptomatically, Axel Leijonhufvud started to study economics seriously after arriving in the United States as a postgraduate student from Lund.

15 Swedish economics research in the 1980s is reviewed below in Chapter 6.

16 See Klevmarken (1974) for a brief discussion of econometrics in Sweden.

17 The licentiate was an intermediate degree below the doctor's degree (see Chapter 4). To my knowledge six licentiates have become professors of economics (Åke Andersson, Guy Arvidson, Peter Bohm, Gösta Rehn, Ingemar Ståhl, and Bengt-Christer Ysander).

18 It is not uncommon for docents to show great energy in proposing and promoting new chairs in fields of their own specialization.

19 A new reform introduced at the end of the 1980s allows professors' salaries to be linked to academic output.

20 For example, it was claimed that when Fritz Brock heard he was going to be professor in Uppsala 'he laid down his pen, never to pick it up again' (information provided personally by Mats Lemne). However, this is a slight exaggeration. Brock published several articles, many of them critical of Eli Heckscher.

21 Kjeld Philip was urged to apply for the chair at Stockholm in order to prevent Anders Östlind from getting it. Philip had no intention of remaining in Sweden for long (information provided personally by Hugo Hegeland).

22 For a description of the Swedish doctoral system, see Chapter 4.

23 The negative attitude of some of the economics professors to doctoral students is reflected in an anecdote about Fritz Brock, professor at Uppsala in the 1920s and 1930s. As an aspiring doctoral student, Dag Hammarskjöld informed Brock that he wanted to continue to study for a higher degree. Brock replied: 'I cannot prevent you from starting doctoral studies, but I have crushed greater talents than yours' (information provided personally by Mats Lemne, who worked closely with Dag Hammarskjöld at the Ministry of Finance in the 1940s).

24 Ohlin took a few weeks' leave of absence before the general elections. 


\section{Notes and references}

Otherwise he served as full professor and full-time party leader for a long time.

25 On this point, see the introduction to Jonung (1991a).

26 In fact, Silverstolpe obtained a chair at Gothenburg and Petander became a docent in spite of Cassel's efforts to prevent it.

27 This is quite remarkable since $\AA$ kerman became completely deaf in the late 1940s, probably inspiring Erik Lundberg (1984:16) to suggest in his own inimitable way that deafness seemed to be a prerequisite for original work by Swedish professors: 'For a time it seemed that since the days of Wicksell only deaf or otherwise handicapped economists in Sweden spent their time exclusively on basic research and pure theory.'

28 The Swedish tradition has much in common with the Oxbridge tradition as described by Johnson (1973) 'a teacher proves his academic quality by his ability to find fault with the published work of others'.

29 On the subject of economics as a profession, see Klamer and Colander (1990, Chapter 1), and Leijonhufvud (1973) for an elegant introduction.

30 According to oral tradition, Ohlin became a millionaire by wisely investing his earnings from writing economic commentaries in the daily press.

31 The story of the political roles and views of Swedish economists in the 20th century remains to be written.

32 See Ingemar Ståhl's intellectual autobiography in Jonung (1990b).

33 How should this difference be explained? Part of the explanation is to be found in the tradition founded by Wicksell, Cassel and Heckscher. Lack of professionalism among political scientists has contributed to this state of affairs according to two political scientists, Hermansson and Rothstein (1989). Furthermore, since the 1950 s most leading professors in political science were convinced social-democrats, or had leanings towards that party.

34 See Ohlin's and Myrdal's argument as translated in Jonung (1990a). Tord Palander published his thesis in German, which probably inhibited international recognition of his work.

35 The description of European doctoral training in Portes (1987:1336) aptly applies to Sweden: 'Until recently the typical European "research training" was to let the student go to some lectures while getting on with a thesis intended to be both a survey of existing research on the topic and a major original and publishable contribution to knowledge, in short, a book. In practice the thesis was seldom short (often absurdly long, as with the French Doctorat d'Etat) and usually did not become a book, either because it was never finished or because the verbosity merely disguised just a single idea, hence a single article.'

\section{References}

Blaug, M. (1985) Great Economists since Keynes, Brighton: Wheatsheaf.

Carlson, B. and Jonung, L. (1989) 'Gustav Cassels artiklar i Svenska Dagbladet. Register 1903-1944' (Gustav Cassel's Articles in the Svenska Dagbladet 1903-1944), Meddelande från Ekonomisk-historiska institutionen. Lunds universitet. No. 62. 
Cassel, G. (1941) I förnuftets tjänst (In the Service of Reason), Stockholm: Natur \& Kultur.

Coats, A. W. (1980) 'The Culture and the Economists: Some Reflections on Anglo-American Differences', History of Political Economy, 12, 4:588-609. (1985) 'The American Economic Association and the Economics Profession', Journal of Economic Literature, 23, 4:1697-1727.

Colander, D. (1989b) 'Research on the Economics Profession', Journal of Economic Perspectives, 3, 4:137-48.

Gårdlund, T. (1956) Knut Wicksell. Rebell $i$ det nya riket (Published in English as The Life of Knut Wicksell by Almqvist and Wiksell in 1958), Stockholm: Bonniers.

Hermansson, J. and Rothstein, B. (1989) 'Politikens teser och vetenskapliga argument' (The Theses of Politics and Scientific Arguments), Statsvetenskaplig tidskrift, 92, 3:193-9.

Johnson, H. G. (1973) 'National Styles in Economic Research: The United States, the United Kingdom, and Various European Countries', Daedalus, 102, 2:65-74.

- (1977) 'The American Tradition in Economics', Nebraska Journal of Economics and Business, 16, 3:17-26.

Jonung, L. (ed.) (1990a) The Stockholm School of Economics Remembered (in preparation).

- (ed.) (1990b) Nya fält för marknadsekonomin (New Fields for the Market Economy) (tillägnad Ingemar Ståhl), Stockholm: SNS förlag.

- (ed.) (1991a) The Stockholm School of Economics Revisited, New York: Cambridge University Press: 9-22.

- (ed.) (1991b) Swedish Economic Thought: Explorations and Advances, London: Routledge (forthcoming).

Jungenfelt, K. and Lindbeck, A. (1973) 'Economic Research in Sweden during the Post-war Period', in Social Science Research in Sweden, Stockholm: Scandinavian University Press.

Klamer, A. and Colander, D. (1990) The Making of an Economist, Boulder: Westview Press.

Klevmarken, A. (1974) 'Ekonometrins ställning i Sverige' (The Status of Econometrics in Sweden), Ekonomisk debatt, 2, 4:245-8.

Knudtzon, E. J. (1976) Knut Wicksells tryckta skrifter 1868-1950 (Knut Wicksell's Published Works 1868-1950), Acta Universitatis Lundensis, Sectio I. Theologica, Juridica, Humaniora 25, Lund: Gleerups.

Landgren, K.-G. (1957) Economics in Modern Sweden, Washington, DC: Library of Congress (Translation from the Swedish by Paul Gekker).

Leijonhufvud, A. (1973) 'Life Among the Econ', Western Economic Journal, 11, September:327-37. Reprinted as Chapter 12 in A. Leijonhufvud (1981) Information and Coordination. Essays in Macroeconomic Theory, New York: Oxford University Press.

Lindbeck, A. (1971) The Political Economy of the New Left: An Outsider's View, New York: Harper \& Row.

Lundberg, E. (1953) Konjunkturer och ekonomisk politik (Business Cycles and Economic Policy), Stockholm: SNS.

(1984) Kriserna och ekonomerna (The Crises and the Economists), Stockholm: Liber. 


\section{Notes and references}

Myrdal, G. (1927) Prisbildningsproblemet och föränderligheten (The Problem of Price Formation and Variability), Uppsala: Almqvist \& Wiksell.

Ohlin, B. (1924) Handelns teori (The Theory of Trade), Stockholm: Centraltryckeriet.

Olsson, U. (1989) 'Att . . . befrämja affärsverksamhetens höjande i vårt land' (To ... Promote the Raising of Business Activity in Our Country), Skrift till Handelshögskolans i Stockholm 80-årsjubileum den 1 oktober 1989, Handelshögskolan, Stockholm.

Portes, R. (1987) 'Economics in Europe', European Economic Review, 31, August:1329-40.

Sandelin, B. (ed.) (1991) The History of Swedish Economic Thought, London: Routledge.

Stigler, G. and Friedland, C. (1979) 'The Pattern of Citation Practices in Economics', History of Political Economy, 11, 1:1-20.

Svennilson, I. (1938) Ekonomisk planering (Economic Planning), Uppsala: Almqvist \& Wiksell (thesis).

\section{THE ECONOMICS OF SWEDISH ECONOMICS IN THE} 1980s

Notes

1 For a comprehensive English summary of the Swedish research system, see Ohrström (1991). A recent commentary in English on higher education in Sweden is provided by Scott (1991).

2 It has been suggested that this last part of the procedure be abolished in the future.

3 The resource allocation system is now moving towards a more decentralized system, whereby universities are allocated lump sums.

4 The internal research grants were created in the 1970s in response to the problems arising from the heavy teaching load of lecturers (högskolelektorer) in the Swedish universities. For some time a distinction was made between 'research to maintain competence' and 'front-line research'. Nowadays all research is expected to be of this second kind.

5 The following discussion is limited to the Swedish research-granting bodies. In addition to those mentioned there are also a number of Nordic bodies which aim to support research across the Nordic borders.

6 For a summary of the historical development of the Swedish research councils, cf. SOU 1975:26:39-65. The first twenty-five years of the earlier Social Science Research Council have been treated in Social Science Research in Sweden (1973).

7 As was mentioned above, the research councils may also create research positions. Some of these are permanent, but most are limited to six years.

8 Among those appointed by the government is the chairman of the Council. The representatives of the researchers are elected in a very elaborate democratic process. First the different universities choose electors, who then meet first to select a research committee, and later to vote on the committee's proposal. The mandate period for council members is three years, with one chance of re-election (in order to provide for continuity). 
9 The general principles of resource allocation are thus an evergreen subject of discussion at the Research Council, particularly during the first year of a newly appointed council. Changes are difficult to accomplish, however, due to the apparently inevitable inertia associated with organizational change.

10 As the name indicates the foundation was created to celebrate the 300th anniversary of the foundation of the Bank of Sweden, the oldest existing central bank in the world. It has to be added, however, that the celebration 'made a false start', since the bank was actually established in 1668 .

11 For the history of the Foundation and the presentation of some of its major research programmes, cf. Härnqvist and Svensson (1990).

12 Since the advent of fax machines the Foundation has increasingly been able to include foreign experts in this work. This is another example of the growing integration of the Swedish scientific community into a world wide network (cf. pages 11-16 above and the reference to David Lodge's fictional hero Morris Zapp).

13 Examples of two such large projects in economics are 'The Internationalization Process and National Economic Policies' at IIES and 'Environment, Natural Resources and Society' at the Stockholm School of Economics (cf. Lindbeck 1990 and Dahmén and Mäler, 1990).

14 Source: The Annual Reports of the Bank of Sweden Tercentenary Foundation. The corresponding figures for economics were somewhat more favourable: 50 per cent and 61 per cent respectively. It should also be noted that the trend as regards rejection rates has generally been upwards and that the American NSF economics panel's rejection rate has now risen to about 75 per cent (information provided personally by Avinash K. Dixit). In interpreting rejection rates in the Swedish context it should be kept in mind that applications are not infrequently sent to more than one research-granting body.

15 Cf. e.g. Ds Bo 1982:2 and SOU 1991:23, concerning the Swedish Council for Building Research (BFR). The first of these scrutinies resulted in some resources being transferred from BFR to HSFR. Of the SEK 5 million transferred per year, SEK 1 million turned out to be earmarked for experiments in construction! Needless to say this was not altogether appreciated by the members of the Research Council.

16 A recent expression of this tendency is the creation of the Swedish Council for Social Research (SFR), which was set up in 1990.

17 This arrangement, like the research positions provided by the HSFR, are of course not without complications, since the universities have the responsibility for the persons appointed after the conclusion of the initial financing period.

18 Although based on a donation from a government body, the Bank of Sweden Tercentenary Foundation is a private foundation. It was discussed on pages 50-1, however, since its character as a distributor of grants closely resembles that of the research councils.

19 This form of financing, which is primarily used for doctoral students, is of course more cost-effective for the foundations than the payment of salaries and social costs. It is sometimes combined with the payment of insurance, since holders of scholarships are not included in the social security system. These tax-free scholarships are not significant in terms of size, but they 


\section{Notes and references}

represent an important ingredient of research funding in Sweden. Evidence of this was provided in the autumn of 1990, when a proposal that scholarships should be taxed was discussed and finally rejected (cf. e. g. Engwall and Engwall 1990).

20 The index gives the following values for the years studied: $1.87(1980-1)$, 1.75 (1981-2), 1.63 (1982-3), 1.53 (1983-4), 1.46 (1984-5), 1.37 (1985-6), 1.29 (1986-7), 1.22 (1987-8), $1.15(1988-9)$ and 1.00 (1989-90).

21 The special status of IIES is borne out by the fact that it is financed by government grants and by a foundation. Until the academic year 1990-1 the first of these were allocated in the form of a special appropriation, but since 1 July 1990 they have been included in the grants for the Faculty of Social Sciences at Stockholm University (Government Bill 1989/90:90, p. 257). It is worth noting that IIES and SOFI have no doctoral programmes of their own. Doctoral students do their main thesis work at these institutes and present the formal defence of their theses at their original department, generally the Department of Economics of Stockholm University or at the Stockholm School of Economics.

22 IIES differs from the other departments in not having a grant for undergraduate education. However, in principle this difference should not influence the resources for research significantly, since grants for undergraduate programmes are not supposed to be used for research purposes.

23 This index consists of the sum of the squared market shares, and assumes the limiting values zero and one. It was developed independently by both Herfindahl and Hirschman, and is therefore designated $\mathbf{H H}$ (cf. Hirschman 1964).

24 Another source of research financing not covered by the present study comes from the full or part-time employment of university researchers in research institutes such as the Industrial Institute for Economic and Social Research (IUI) and the Trade Union Institute for Economic Research (FIEF).

25 The figures have been taken from the annual reports of HSFR and the Bank of Sweden Tercentenary Foundation.

26 The figure may be even higher, since some grants from the Research Council and the Tercentenary Foundation have been given to researchers outside the universities and the Stockholm School of Economics.

27 Data of this kind could of course be collected, but the extension of the analysis in this way would lead to a number of problems. The main difficulty is that these foundations primarily award tax-free grants, which are worth more to the recipient than their nominal value would suggest. There would also be problems of delimitation.

28 Similar research activities have been undertaken in the Industrial Institute for Economic and Social Research (IUI) since 1939 and on the initiative of the Centre for Business and Policy Studies (SNS, founded in 1948). For an analysis of the creation of IUI, cf. Henriksson (1990).

29 The annual allocation to FIEF from the Federation of Labour was set, at the time of its foundation in 1985, at SEK 5 million at 1983 prices (information provided personally by Villy Bergström). Implementation of this decision would mean that during the period studied here FIEF has received a little less than SEK 36 million at $1989-90$ prices. The cor- 
responding figure for IUI, which was in operation throughout the period, could be estimated at around SEK 80 million.

\section{References}

Dahmén, E. and Mäler, K.-G. (1990) 'Environment, Natural Resources and Society', in K. Härnqvist and N.-E. Svensson (eds) (1990) Swedish Research in a Changing Society, Hedemora: Gidlunds förlag 193-211.

Ds Bo 1982:2, Byggforskningen - en översyn och utvärdering. Slutrapport från Byggforskningsutredningen (Building Research - A Review and Evaluation. Final Report from the Building Research Commission), Stockholm: Bostadsdepartementet.

Engwall, G. and Engwall, L. (1990) 'Ingen skatt på stipendier' (No Tax on Scholarships), Upsala Nya Tidning, 18 September 1990.

Government Bill 1986/87:80, Om forskning (On Research), Stockholm: Regeringskansliet.

Government Bill 1989/90:90, Om forskning (On Research), Stockholm, Regeringskansliet.

Härnqvist, K. and Svensson, N.-E. (eds) (1990) Swedish Research in a Changing Society, Hedemora: Gidlunds förlag.

Henriksson, R. G. H. (1990) Som Edström ville - hur IUI blev till (As Edström Wanted - How IUI was Founded), Stockholm: IUI.

Hirschman, A. O. (1964) 'The Paternity of an Index', American Economic Review, 54, September:761-2.

Lindbeck, A. (1990) 'Internationalization Process and National Economic Policies', in K. Härnqvist and N.-E. Svensson (eds) (1990) Swedish Research in a Changing Society, Hedemora: Gidlunds förlag: 123-39.

Ohrström, L. (1991) Research. The Swedish Approach, Stockholm: The Swedish Institute.

Scott, P. (1991) Higher Education in Sweden - A Look from the Outside, Stockholm: UHÄ and the 1989 Government Committee on Higher Education.

Social Science Research in Sweden (1973) Stockholm: Scandinavian University Books.

SOU 1975:26, Forskningsråd (Research Councils), Stockholm: Utbildningsdepartementet.

SOU 1991:23, Ett nytt BFR - byggforskningen på 90-talet (A New BFR Building Research in the Nineties), Stockholm: Bostadsdepartementet.

Statistiska Meddelanden N14SM9001, 1990, Nationalräkenskaper 1980-1990 (National Accounts 1980-1990), Orebro: Statistics Sweden.

Stenkula, P. (1985) Tre studier över resursanvändningen i högskolan (Three Studies of Resource Use in Higher Education), Lund Economic Studies 36, Lund (thesis).

(1986) Produktions-, kostnads- och produktivitetsutveckling inom den offentligt finansierade utbildningssektorn 1960-1980 (The Development of Production, Costs and Productivity in the Publicly Financed Educational Sector 1960-1980), Stockholm: Finansdepartementet (DsFi 1986: 17).

UHÄ Reports 1980:16, 1981:18, 1982:17, 1983:8, 1984:10, 1985:5, 1986:15, 1988:9. 1989:7. 1990:3 and 1991:11. 


\section{Notes and references}

\section{RECRUITING A NEW GENERATION}

\section{Notes}

1 I have benefited from many helpful comments by Lars Engwall, Ante Farm, Elving Gunnarsson, Daniel Hamermesh, Lars Jonung, Henry Ohlsson, Lena Schröder and Claes-Henric Siven. Ingrid Munkhammar and Folke Carlsson have skilfully assisted me with the computations carried out for this study at SCB, Orebro. Information on Ph.D. degrees received by Swedish citizens in the United States presented on pages 84-6 has been prepared for this chapter by Lori Thurgood, the National Research Council, Washington, DC, whom I would also like to thank for several helpful comments.

2 Five licentiates in economics received an old $\mathrm{Ph} . \mathrm{D}$. in other disciplines, in most cases in history. Two earned a new Ph.D. in other disciplines. On the other hand seven of those receiving an old $\mathrm{Ph} . \mathrm{D}$. in economics had licentiates in other disciplines. The best-known examples are Knut Wicksell (mathematics) and Erik Lindahl (fiscal law), but two other professors in economics received their licentiate degrees in other areas Emil Sommarin (Scandinavian languages) and Johan Åkerman (statistics). Lindahl presented the same thesis for his licentiate degree in fiscal law as for his doctoral degree. Three professors of economics in Sweden have received their $\mathrm{Ph} . \mathrm{D}$. degrees in subjects other than economics. They are Gustav Cassel (mathematics), Sven Brisman (history) and Roland Artle (business administration).

3 In reaching this figure the faculty of law, where the same thesis was usually presented for both the licentiate and the doctorate degree, was excluded. For fourteen people who changed universities between the two degrees, the average time elapsing between the two degrees was 8.3 years.

4 When Dag Hammmarskjöld defended his thesis, Gunnar Myrdal was the first opponent, and Karin Kock the second. Bertil Ohlin acted as extra opponent. The public defence began at 10.15 a.m. and ended at 5.00 p.m. Relations between Hammarskjöld and Ohlin were never friendly again.

Tord Palander was a well-known extra opponent in the post-war period. When Karl Jungenfelt defended his thesis at Stockholm University, Tord Palander's extra opposition prolonged the public defence of the thesis to a total of seven hours. For a lively description of Palander's career as extra opponent, see Puu (1991).

5 Hegeland gives a personal account of the consequences for those who failed a grade qualifying them for docent status. 'Professor Gustaf Åkerman explained at dinner that, as far as he could see, my thesis would qualify for a docentship. Older and more critical competitors changed his mind however, so I was forced to content myself with a Cum laude on my thesis and defense. Shortly after I accepted Johan Akerman's offer to be assistant lecturer at the University of Lund' (Hegeland 1988:285).

6 Several professors of economics (Åke Andersson, Guy Arvidsson, Peter Bohm, Gösta Rehn, Ingemar Ståhl and Bengt-Christer Ysander) have licentiate degrees of the old model as their highest academic degree.

7 It is remarkable that the Gothenburg School of Economics awarded no licentiate or doctoral degrees in economics according to the old system 
until it became part of Gothenburg University on 1 July 1971. The departments of economics of the University and of the School of Economics were merged on that date.

8 In the early 1960 s only 5 per cent of all licentiate theses in the humanities and social sciences received this grade (SOU 1966:67, p. 110). One of the three, Dag Hammarskjöld, was later awarded a Ph.D. at Stockholm University. At the same time that Brock was professor at Uppsala, only seven out of 24 were given the lowest grade at Stockholm University. (Altogether 26 received the licentiate degree but it has not been possible to get information on the grade for those presenting their licentiate theses in 1922.)

9 Later the conflict between the two professors at Uppsala, Lindahl and Palander, led to a new period of low output, but still much higher than under Brock. See Hegeland (1988) and Bentzel (1991).

10 Also teacher categories such as assistant professors (forskarassistent) and lecturers (högskolelektor) may be engaged as advisers.

11 The statistics may be somewhat misleading as many of those holding a chair have only been acting as professor for a few years. There may also be differences between who is formally the supervisor and who in practice is the supervisor, making the statistics difficult to interpret.

12 Note, however, that as many as 48 per cent of the doctorates in economics were awarded to students who were not citizens of the United States, and that such students tend to complete their doctoral work faster than the country's own citizens. The median age of US citizens receiving a Ph.D. in economics may be fairly close to that of Swedish citizens receiving a Ph.D. in economics in Sweden. (Information received from Lori Thurgood, National Research Council, in letter of 25 April 1991.)

13 No reliable statistics exist on the percentage of students who drop out of their postgraduate courses without taking a degree in economics in Sweden. In the United States as many as 70 per cent of those who complete their general examinations (all subjects) fail to complete their degree (Ziolkowski 1990:185). The dropout rate is probably roughly the same in Sweden.

14 The time up to completion of the Ph.D. thesis may be somewhat shorter. Some students complete their course programme after presenting their theses.

15 The corresponding figures for 1989 in the United States are 8.9 years from the first degree to the Ph.D. in economics, and 6.5 years as a registered research student in economics (Thurgood and Weinman 1990:71).

16 In the United States 19.3 per cent of those obtaining a $\mathrm{Ph}$.D. in economics in 1989 were women (Thurgood and Weinman 1990:71).

17 As a comparison, the average length of US Ph.D. theses in economics was calculated from UMI, Quarterly Update, New Dissertations April-June 1991. All the $171 \mathrm{Ph} . \mathrm{D}$. theses under the heading 'Economics, general', were included, of which almost all were completed in 1990. The average length was very close to 200 pages (199.8 pages per thesis), 13 per cent shorter than the average for Swedish theses. If only the 59 theses from the 20 top departments (see Davis and Papanek 1984:228) are included, the average length becomes 190 .

18 Kumara Vellupillai is currently translating Gunnar Myrdal's thesis. 


\section{Notes and references}

19 Compare this with changes in the percentage distribution of citation by language of source in Ekonomisk Tidskrift and its successors. See table 2.10 .

20 The Swedish term 'opponent' has been used. An alternative would have been 'external examiner'. However, in almost half the cases under the old system the opponent was chosen from the same university (an internal examiner), and in the first few years of the present system this was still quite often the case.

21 Mobility between universities is low in other disciplines as well. According to estimates by Richard Swedberg (1988b), it is even lower among sociologists.

22 A probit estimation gives the following result:

$$
\text { ULM }=-0.145+0.735 \text { AREA }-0.342 \text { USHHS }+0.232 \text { RJHSFR }
$$

Log likelihood $=-133.51 \quad n=203$

ULM $=1$ if remaining at a Swedish university (not necessarily the same university)

AREA $=1$ if a theoretical thesis (area 0)

USHHS $=1$ if graduating from a university in the Uppsala-Stockholm area.

RJHSFR $=1$ if received financial support from the Bank of Sweden Tercentenary Foundation or the Swedish Council for Research in the Humanities and Social Sciences in the course of postgraduate studies.

23 The study is based on information from two registers - 'The Register of Yearly Earnings' (ARSYS) and 'The Research Student Register' (Högskoleregistret). The computations have been made at Statistics Sweden by Folke Carlsson. The author of this chapter has not had access to the individual observations.

24 The number of missing observations is small for all universities with the exception of Umeå University. This is probably due to an under-reporting from Umeå University to Statistics Sweden.

\section{References}

Bentzel, R. (1991) 'Economics at Uppsala from Berch to Lindahl/Palander A Survey', in R. Bentzel et al., Economics at Uppsala University, Uppsala: Department of Economics: 3-13.

Dahllöf, U. (1987) 'Akademiska avhandlingar vid Sveriges universitet och högskolor 1890-1939. En kompletterande sammanställning' (Academic Theses at Swedish Universities 1890-1939. A Supplementary Compilation), Uppsala: Department of Education.

(1989) 'Doctoral Studies and Public Policies Affecting the Labour Market for Ph.D.s in Norway and Sweden', Scandinavian Journal of Educational Research, 33, 3:165-84.

Davis, P. and Papanek, G. (1984), 'Faculty Ratings of Major Economics Departments by Citations', American Economic Review, 74, March:22530.

Engwall, L. (1987) ‘An American Dream. Postgraduate Research Training in the Social Sciences in Sweden', in Postgraduate Research Training in the 
Social Sciences, Copenhagen: International Federation of Social Science Organizations: 122-8.

Fägerlind, I. (1991) 'Utbildningsstandarden i Sverige 1970-1990 och produktivitetsutvecklingen' (The Quality of Education in Sweden 1970-1990 and Productivity Growth), in E. Wadensjö Arbetskraft, arbetsmarknad och produktivitet (The Labour Force, the Labour Market and Productivity), Stockholm: Allmanna Urlagel: 225-56.

Hegeland, H. (1988) Skyddslingarna på Ekedalen (The Protegés at Ekedalen), Gothenburg: Tre Böcker.

Klamer, A. and Colander, D. (1990) The Making of An Economist. Boulder: Westview Press.

Puu, T. (1991) 'Tord Palander and the Uppsala Milieu', in R. Bentzel et al. Economics at Uppsala University, Uppsala: Department of Economics.

SOU 1966:67, Forskarutbildning och forskarkarriär (Research Training and Research Careers), Betänkande avgivet av 1963 års forskarutredning, Stockholm: Ministry of Education.

SOU 1966:68, Forskarutbildning och forskarkarriär (Research Training and Research Careers), Bilagor (Supplements), Stockholm: Ministry of Education.

SOU 1981:29, Forskningens framtid. Forskning och forskarutbildning $i$ högskolan (The Future of Research. Research and Research Training at the University), Betänkande av Utredningen om forskningens och forskarutbildningens situation $\mathrm{i}$ den nya högskolan, Stockholm: Ministry of Education.

SOU 1989:30, Professorstillsättning. En översyn av proceduren vid tillsättning av professorstjänster (Appointment of Professors. An Overview of the Procedure for Appointing Professors), Stockholm: Ministry of Education.

Swedberg, R. (1988b) 'Rörligheten bland svenska sociologer' (Mobility among Swedish Sociologists), in E. Allardt, S. Lysgaard and A. Bøttger Sørensen, Sociologin $i$ Sverige (Sociology in Sweden), Uppsala: Swedish Science Press: 279-87.

Thurgood, D. H. and Weinman, J. M. (1989) Summary Report 1988: Doctorate Recipients from United States Universities, Washington DC: National Academy Press.

_ (1990) Summary Report 1989: Doctorate Recipients from United States Universities, Washington DC: National Academy Press.

Tuckman, H., Coyle, S. and Bae, Y. (1990) On Time to the Doctorate. A Study of the Increased Time to Complete Doctorates in Science and Engineering, Washington DC: National Academy Press.

Wadensjö, E. (1991) 'Högre utbildning och inkomster' (Higher Education and Earnings), in E. Wadensjö Arbetskraft, arbetsmarknad och produktivitet (The Labour Force, the Labour Market and Productivity), Stockholm: Allmanna förlaget: 257-87.

Zetterblom, G. (1986) 'Postgraduate Education in Sweden: Reforms and Results', European Journal of Education, 21, 3:261-73.

_ (1988) 'Forskarutbildningen - underlag för 1990 års forskningsproposition' (Research Training - Basic Information for the 1990 Government Proposition on Research), UḦ̈-rapport 1989:7, Bilaga nr 18.

Ziolkowski, T. (1990) 'The Ph.D. Squid', American Scholar, 59, 2:177-95. 


\section{Notes and references}

\section{SWEDISH ECONOMICS ON THE INTERNATIONAL SCENE}

\section{Notes}

1 The core journals according to Garfield (1989) are: American Economic Review, Brookings Papers on Economic Activity, Canadian Journal of Economics, Econometrica, Economic Inquiry, Economic Journal, Economica, Economics Letters, European Economic Review, International Economic Review, Journal of Development Economics, Journal of Econometrics, Journal of Economic Literature, Journal of Economic Theory, Journal of Financial Economics, Journal of International Economics, Journal of Labor Economics, Journal of Law and Economics, Journal of Mathematical Economics, Journal of Monetary Economics, Journal of Political Economy, Journal of Public Economics, Oxford Economic Papers, Quarterly Journal of Economics, Rand Journal of Economics, Review of Economic Studies, Review of Economics and Statistics.

2 The classification of world output is retrieved via an online search of the JEL.

\section{References}

Allardt, E., Lysgaard, S. and Bøttger Sørensen, A. (1988) Sociologin i Sverige (Sociology in Sweden), Uppsala: Swedish Science Press.

Garfield, E. (1989) 'Journal Citation Studies. 50. Part 1. Introduction to the Core Journals of Economics', Current Contents, 21, 1:3-11.

Gordon, M. D. (1984) 'How Authors Select Journals: A Test of the Reward Maximization Model of Submission Behavior', Social Studies of Science, 14, 1:27-43.

Handbooks in Economics, 1981-1989, Amsterdam: North Holland.

Line, M. B. (1979) The Structure of Social Science Literature as Shown by Citations, Bath: DISISS, Research Reports Series A No 3, Bath University Library.

Lotka, A. J. (1926) 'The Frequency Distribution of Scientific Productivity', Journal of the Washington Academy of Sciences, 16, 12:317-23.

McCain, K. W. (1986) 'Cocited Author Mapping as a Valid Representation of Intellectual Structure', Journal of the American Society for Information Science, 37, 3:111-22.

Persson, O. (1986) 'Svensk forskning 1973-84 - Artikelproduktion och citeringar' (Swedish Research 1973-84 - Article Production and Citations), Bibliometriska notiser, 2, 2:1-2.

Persson, O., Stern, P. and Holmberg, K.-G. (1990) BIBMAP A Toolbox for Mapping the Structure of Scientific Literature, Paper presented at the International Conference of Scientific and Technology Indicators: Representations of Science and Technology, Bielefeld, Germany 10-12 June 1990.

Stern, P. (1990) 'Vetenskapens kognitiva landskap - en bibliometrisk studie av svensk nationalekonomi' (The Cognitive Landscape of Science - A Bibliometric Study of Swedish Economics), Bibliometriska rapporter, No 3, Umeå: Inforsk, Department of Sociology, Umeå University. 


\section{SWEDISH ECONOMICS IN THE 1980s}

\section{Notes}

1 The general point we are making is summed up compactly in the text that P.-O. Johansson and K.-G. Lofgren have published in England, a textbook on forestry and other products. It differs from other texts in giving much more attention to forest products than is usual. That is, of course, specifically Nordic. But 'the book originates from sabbatical leave [. . . ] at the University of Wisconsin'.

2 The work of Erik Dahmén (1950) on economic development is a precursor that should be mentioned in this context. It belongs to the Austrianinstitutionalist or Schumpeterian tradition (cf. Gerschenskron 1968).

3 In 1991 a similar institute was created at the Stockholm School of Economics. It is headed by Bengt Jönsson, who earlier conducted research in the field at Lund and Linköping.

\section{References}

Albrecht, J. and Axell, B., 1984, 'Ar. Equilibrium Model of Search Unemployment', Journal of Political Economy, 92, 5:824-40.

Albrecht, J., Axell, B. and Lang, H. (1986) 'General Equilibrium Wage and Price Distributions', Quarterly Journal of Economics, 101, 4:687-706.

Andersson, Å. E., Anderstig, C. and Hårsman, B. (1990) 'Knowledge and Communications Infrastructure and Regional Economic Change', Regional Science and Urban Economics, 20, 3:359-76.

Andersson, A. E., Kallio, M. and Seppälä, R. (1986) 'Systems Analysis for the Forest Sector', TIMS Studies in the Management Sciences 21: 1-23.

Andersson, $\AA$. E. and Kuenne, R. E. (1986) 'Regional Economic Dynamics', in P. Nijkamp (ed.) (1986) Handbook of Regional and Urban Economics, Vol. I, Amsterdam: Elsevier: 201-53.

Banks, F. E. (1976) The Economics of Natural Resources, New York: Plenum Press.

Beckmann, M. and Puu, T. (1990) Spatial Structures, Berlin: Springer-Verlag.

Bergman, L. (1988) 'Energy Policy Modelling: A Survey of General Equilibrium Approaches', Journal of Policy Modeling, 10, 3:377-99.

Bergman, L. and Lundgren, S. (1990) 'General Equilibrium Approaches to Energy Policy Analysis in Sweden', in L. Bergman, D. Jorgenson and E. Zalai (eds) General Equilibrium Modeling and Economic Policy Analysis, Oxford: Basil Blackwell: 351-82.

Bergström, C. and Rydquist, K. (1990) 'The Determinants of Corporate Ownership: An Empirical Study on Swedish Data', Journal of Banking and Finance, 14, 2/3:237-53.

Bergström, R. and Edin, P.-A. (1991) 'Time Aggregation and the Distributional Shape of Unemployment Duration', Journal of Applied Econometrics (forthcoming).

Bergström, R. and Wold, H. (1983) Fix Point Estimation in Theory and Practice, Guttingen: Van den Hoeck and Ruprecht.

Björklund, A. and Persson-Tanimura, I. (1983) 'Youth Employment in 


\section{Notes and references}

Sweden', in B. G. Reubens (ed.) (1983) 'Youth at Work. An International Survey, Totowa, NJ: Rowman and Allanheld: 232-68.

Blomquist, S. (1990) 'Nonconvex Preferences and Coherency for Labor Supply Models', Working Paper, Department of Economics, Princeton University.

Blomström, M. (1986a) 'Multinationals and Market Structure in Mexico', World Development, 14, 4:523-30.

- (1986b) 'Foreign Investment and Productive Efficiency: The Case of Mexico', Journal of Industrial Economics, 35, 1:97-110.

Bohm, P. (1984) 'Revealing Demand for an Actual Public Good', Journal of Public Economics, 24, 2:135-51.

_ (1987a) 'Second Best', 'External Economies', and 'Lindahl on Public Finance', in J. Eatwell, M. Milgate and P. Newman (eds) (1987) The New Palgrave: A Dictionary of Economics, London: Macmillan, Vol. 2:261-3, Vol. 3:200-1 and Vol. 4:280-3.

- (1987b) Social Efficiency - A Concise Introduction to Welfare Economics, (2nd edn), London: Macmillan.

Bohm, P. and Russell, C. S. (1985) 'Comparative Analysis of Alternative Policy Instruments', in A. V. Kneese and J. L. Sweeney (eds) (1985) Handbook of Natural Resource and Energy Economics, Vol. I, Amsterdam: North-Holland: 395-460.

Brownstone, D., Englund, P. and Persson, M. (1988a) 'A Micro-simulation Model of Swedish Housing Demand', Journal of Urban Economics, 23, 2:179-98.

- (1988b) 'Tax Reform and Housing Demand: The Distribution of Welfare Gains and Losses', European Economic Review, 32, April:819-40.

Calmfors, L. (1977) 'Inflation in Sweden', in L. B. Krause and W. S. Salant (eds) (1977) Worldwide Inflation: Theory and Recent Experience, Washington: Brookings Institution: 493-544.

- (1978) Prices, Wages and Employment in the Open Economy, Monograph No. 10, Stockholm: IIES.

(1990) Wage Formation and Macroeconomic Policy in the Nordic Countries, Stockholm and Oxford: SNS Förlag and Oxford University Press.

Calmfors, L. and Driffill, J. (1988) 'Bargaining Structure, Corporatism and Macroeconomic Performance', Economic Policy, 6, April: 14-61.

Carlsson, H. (1988) 'Time Consistency, Coordination and Forward Induction', Working Paper, University of Lund.

Cuddington, J. T., Johansson, P.-O. and Löfgren, K.-G. (1984) Disequilibrium Macroeconomics in Open Economies, Oxford: Basil Blackwell.

Dahmén, E. (1950) Svensk industriell företagarverksamhet. Kausalanalys av den industriella utvecklingen 1919-1939 (Entrepreneurial Activity in Swedish Industry, 1919-1939), Stockholm: IUI; with an English Summary.

Edin, P.-A. and Zetterberg, J. (1989) 'Inter-industry Wage Differentials: Evidence from Sweden and a Comparison with the United States', Working Paper, Department of Economics, Uppsala University.

Eliasson, G. (1988) 'Schumpeterian Innovation, Market Structure, and the Stability of Industrial Development', in H. Hanusch (ed.) (1988) Evolutionary Economics: Applications of Schumpeter's Ideas, Cambridge: Cambridge University Press: 151-99. 
Englund, P. and Svensson, L. E. O. (1988) 'Money and Banking in a Cash-InAdvance Economy', International Economic Review, 29, 4:681-705.

Ethier, W. and Horn, H. (1984) 'A New Look at Economic Integration', in H. Kierzkowski (ed.) (1984) Monopolistic Competition and International Trade, Oxford: Clarendon Press: 207-29.

Ethier, W. J. and Svensson, L. E. O. (1986) 'The Theorems of International Trade with Factor Mobility', Journal of International Economics, 20, February:21-42.

Farm, A. (1988) 'Cooperative Oligopolistic Pricing', European Journal of Political Economy, 4, 1:13-28.

Farm, A. and Weibull, J. (1987) 'Perfectly Flexible Pricing in a Homogeneous Market', Scandinavian Journal of Economics, 89, 4:487-95.

Flam, H. and Helpman, E. (1987a) 'Industrial Policy Under Monopolistic Competition', Journal of International Economics, 22, February:79-102.

- (1987b) 'Vertical Product Differentiation and North-South Trade', American Economic Review, 77, December:810-22.

Flood, L. R. (1985a) 'A Monte Carlo Comparison of the Maximum Likelihood and the Corrected OLS estimators for Tobit Models', Economics Letters, 19:155-63.

- (1985b) 'Using Bootstrap to Obtain Standard Errors of System Tobit Coefficients', Economics Letters, 19:339-42.

- (1988) 'Effects of Taxes on Nonmarket Work', Journal of Public Economics, 36, 2:259-67.

Flood, L. R. and Tasiran, A. (1990) 'A Monte Carlo Comparison of System Tobit Estimators', Economics Letters, 33:249-54.

Førsund, F. and Hjalmarsson, L. (1983) 'Technical Progress and Structural Change in the Swedish Cement Industry 1955-1979', Econometrica, 51, 5:1449-67.

- (1987) Analysis of Industrial Structure: A Putty-Clay Approach, Stockholm: Almqvist and Wiksell International.

Gerschenkron, A. (1968) Continuity in History and Other Essays, Cambridge, MA: Harvard University Press.

Gottfries, N. (1986) 'Price Dynamics of Exporting and Import-Competing Firms', Scandinavian Journal of Economics, 88, 2:417-36.

Gottfries, N. and Horn, H. (1987) 'Wage Formation and the Persistence of Unemployment', Economic Journal, 97, December:877-84.

Grossman, G. and Horn, H. (1988) 'Infant-Industry Protection Reconsidered: The Case of Informational Barriers to Entry', Quarterly Journal of Economics, 103, 4:767-87.

Hamilton, C. (1985) 'Economic Aspects of Voluntary Export Restraints', in D. Greenaway (ed.) (1985) Current Issues in International Trade, London: Macmillan: 99-117.

(1986) 'An Assessment of Voluntary Restraints on Hong Kong Exports to Europe and the USA', Economica, 53, August:339-50.

Hamilton, C. and Svensson, L.E. O. (1983) 'On the Choice Between Capital Import and Labor Export', European Economic Review, 20, 1-3:167-92.

- (1984) 'Do Countries' Factor Endowments Correspond to the Factor Contents in Their Bilateral Trade Flows?', Scandinavian Journal of Economics. 86. 1:84-97. 


\section{Notes and references}

Hansson, I. and Stuart, C. (1985a) 'Tax Revenue and the Marginal Cost of Public Funds in Sweden', Journal of Public Economics, 27, August:331-53.

- (1985b) 'Progressive Taxation as Social Insurance and as Median Voter Outcomes', Scandinavian Journal of Economics, 87, 3:487-99.

__ (1989) 'Social Security as Trade Among Living Generations', American Economic Review, 79, December:1182-95.

Hausman, J. A. (1985) 'Taxes and Labor Supply', in A. J. Auerbach, and M. Feldstein (eds) (1985) Handbook of Public Economics, Volume I, Amsterdam: North-Holland: 213-63.

Holmlund, B., Löfgren, K.-G. and Engström, L. (1989) Trade Unions, Employment, and Unemployment Duration, Oxford: Clarendon Press.

Holmlund, B. and Zetterberg, J. (1989) 'International Evidence on Industry Wage Determination', Working Paper, Department of Economics, Uppsala University.

Horn, H. (1983) Imperfect Competition in Models of Wage Formation and International Trade, Monograph No. 15, IIES, Stockholm.

Horn, H. and Persson, T. (1988) 'Exchange Rate Policy, Wage formation and Credibility', European Economic Review, 32, October:1621-36.

Hörngren, L. and Vredin, A. (1989) 'Exchange Risk Premia in a Currency Basket System', Welfwirtschaftliches Archiv, 125, Heft 2:311-25.

Jacobsson, L. and Lindbeck, A. (1969) 'Labor Market Conditions, Wages and Inflation - Swedish Experiences 1955-67', Swedish Journal of Economics, 71, 2:64-103.

Johansson, P.-O. (1982) 'Cost-Benefit Rules in General Disequilibrium', Journal of Public Economics, 18, June:121-37.

Johansson, P.-O. and Löfgren, K.-G. (1985) The Economics of Forestry and Natural Resources, Oxford: Basil Blackwell.

Jonung, C. (1984) 'Patterns of Occupational Segregation by Sex in the Labor Market', in G. Schmid and R. Weitzel (eds) (1984) Sex Discrimination and Equal Opportunity, Aldershot: Gower: 44-68.

Jonung, L. and Laidler, D. (1988) 'Are Perceptions of Inflation Rational? Some Evidence from Sweden', American Economic Review, 78, 5:1080-7.

Jungenfelt, K. G. (1986) 'Intertemporal Aspects of Learning New Techniques', Scandinavian Journal of Economics, 88, 1:157-87.

Klevmarken, A. N. (1981) On the Complete Systems Approach to Demand Analysis, Stockholm: Almqvist and Wiksell International.

- (1984) 'Household Market and Nonmarket Activities. The First Year of a Swedish Panel Study', Proceedings of the American Statistical Association, Business and Economic Statistics Section:52-7.

(1986) 'Collection Data for Micro Analysis: Experiences from the HUSPilot Study', in G. H. Orcutt, J. Merz, and H. Quinke (eds) Microanalytic Simulation Models to Support Social and Financial Policy, Amsterdam: North-Holland: 369-95.

Kotlikoff, L., Persson, T. and Svensson, L. E. O. (1988) 'Social Contracts as Assets: A Possible Solution to the Time-Consistency Problem', American Economic Review, 78, 4:662-77.

Lindbeck, A. (ed.) (1979) Inflation and Employment in Open Economies, Amsterdam: North-Holland.

Lindbeck, A. and Snower, D. J. (1988) The Inside-Outside Theory of 
Employment and Unemployment, Cambridge, MA and London: MIT Press.

Lindbeck, A. and Weibull, J. W. (1986) 'Intergenerational Aspects of Public Transfers, Borrowing, and Debt', Scandinavian Journal of Economics, 88, 1:239-67.

- (1987) 'Balanced Budget Redistribution as the Outcome of Political Competition', Public Choice, 52, 3:273-97.

- (1988a) 'Altruism and Time Consistency: The Economics of Fait Accompli', Journal of Political Economy, 96, 6:1165-82.

- (1988b) 'Welfare Effects of Alternative Forms of Public Spending', European Economic Review, 32, January:101-27.

Lindgren, B. and Persson, U. (1989) 'The Cost-Effectiveness of a New Antihypertensive Drug, Doxazosin', Current Therapeutic Research, 45, May:738-60.

Löfgren, K.-G. (1991) 'Macroeconomic Model Building in Sweden - An Incomplete Survey', Scandinavian Journal of Economics, 93, 2:331-7.

Löfgren, K.-G., Bångman, G. and Wiberg, A. (1986) 'The Supply of Roundwood and Taxation', in M. Kallio, et al., Systems Analysis in Forestry and Forest Industries, TIMS Studies in the Management Sciences 21, Amsterdam: North Holland:227-44.

Lybeck, J. A. et al. (1984) 'A Comparison of the Dynamic Properties of Five Nordic Macroeconomic Models', Scandinavian Journal of Economics, 86, 1:35-51.

Lyttkens, C. H. (1988) 'Workers' Compensation and employees' Safety Incentives in Sweden', International Review of Law and Economics, 8, 2:181-5.

Mäler, K.-G. (1974) Environmental Economics: a Theoretical Inquiry, Baltimore, MD: Johns Hopkins University Press.

- (1990) 'International Environmental Problems', Oxford Review of Economic Policy, 6, 1:80-108.

Markusen, J. and Svensson, L. E. O. (1985) 'Trade in Goods and Factors with International Differences in Technology', International Economic Review, 26, February:175-92.

Marion, N. P. and Svensson, L. E. O. (1984) 'World Equilibrium with Oil Price Increases: An Intertemporal Analysis', Oxford Economic Papers, 36, March:86-102.

Nyquist, H. (forthcoming) 'Optimal Designs of Discrete Response Experiments in Contingent Valuation Studies', Review of Economics and Statistics.

Pelikan, P. (1989) 'Evolution, Economic Competence, and the Market for Corporate Control', Journal of Economic Behavior and Organization, 12, 3:279-303.

Persson, M., Persson, T. and Svensson, L. E. O. (1987) 'Time Consistency of Fiscal and Monetary Policy', Econometrica, 55, 6:1419-31.

Persson, T. (1982) Studies of Alternative Exchange Rate Systems: An Intertemporal General Equilibrium Approach, Monograph No. 13, IIES, Stockholm.

Persson, T. and Svensson, L. E. O. (1983) 'Is Optimism Good in a Keynesian Economy?', Economica, 50, August:291-300. 


\section{Notes and references}

(1984) 'Misperceptions, Rigidity and Welfare', European Economic Review, 25, August:387-99.

- (1985) 'Current Account Dynamics and the Terms of Trade: HarbergerLaursen-Metzler Two Generations Later', Journal of Political Economy, 93, February:43-65.

Persson, T. and Tabellini, G. (1990) Macroeconomic Policy Credibility and Politics, London and New York: Harwood Academic Publishers.

Persson, U., Montgomery, F., Karlsson, Å. and Lindgren, B. (1988) 'How Far Does Prophylaxis Against Infection in Total Joint Replacement Offset Its Cost?', British Medical Journal, 296, January:99-102.

Puu, T. (1979) The Allocation of Road Capital in Two-Dimensional Space, Amsterdam: North Holland.

Radetzki, M. (1982) 'Has Political Risk Scared Mineral Investment away from the Deposits in Developing Countries?', World Development, 10, $1: 39-48$.

- (1989a) A Guide to Primary Commodities in the World Market, Oxford: Basil Blackwell.

- (1989b) 'Precious Metals: The Fundamental Determinants of their Price Behaviour', Resources Policy, 15, 3:194-208.

Radetzki, M. and Van Duyne, C. (1984) 'The Response of Mining Investment to a Decline in Economic Growth: The Case of Copper in the 1970s', Journal of Development Economics, 15, May-June-August:19-45.

Schmid, G. and Weitzel, R. (eds) (1984) Sex Discrimination and Equal Opportunity, Aldershot: Gower.

Siven, C.-H. (1985) 'The End of the Stockholm School', Scandinavian Journal of Economics, 87, 4:577-93.

Skogh, G. (1982) 'Public Insurance and Accident Prevention', International Review of Law and Economics, 2, 1:67-80.

- (1989) 'The Transaction Costs Theory of Insurance: Contracting Impediments and Costs', Journal of Risk and Insurance, 4, 56:726-32.

Skogh, G. and Stuart, C. (1982) 'A Contractarian Theory of Property Rights and Crime', Scandinavian Journal of Economics, 84, 1:27-40.

Södersten, B. (1980) International Economics, (2nd edn) London: Macmillan.

Svensson, L. E. O. (1980) 'Effective Demand and Stochastic Rationing', Review of Economic Studies, 47, 2:339-55.

- (1984) 'Walrasian and Marshallian Stability', Journal of Economic Theory, 34, December:371-9.

- (1985) 'Money and Asset Prices in a Cash-in-Advance Economy', Journal of Political Economy, 93, October:919-44.

_ (1986) 'Sticky Goods Prices, Flexible Asset Prices, Monopolistic Competition, and Monetary Policy', Review of Economic Studies, 53, July:385405.

Svensson, L. E. O. and Razin, A. (1983) 'The Terms of Trade and the Current Account: The Harberger-Laursen-Metzler Effect', Journal of Political Economy, 91, February:97-125.

Svensson, L.-G. (1983) 'Large Indivisibles: An Analysis with Respect to Price Equilibrium and Fairness', Econometrica, 51, 4:939-54.

- (1988) 'Fair Wages when Individual Choice Sets are Incomplete - An Application of a Model with Indivisibilities', Scandinavian Journal of Economics. 90. 4:563-73. 
(1989) 'Fairness, the Veil of Ignorance and Social Choice', Social Choice and Welfare, 6:1-17.

Svensson, L.-G. and Weibull, J. W. (1984) 'Stability and Efficiency from a Neo-Keynesian Viewpoint', Journal of Economic Dynamics and Control, 7, September:349-62.

- (1986) 'An Upper Bound on Optimal Income Taxes', Journal of Public Economics, 30, July:165-81.

- (1987) 'Constrained Pareto-Optimal Taxation of Labour and Capital Incomes', Journal of Public Economics, 34, December:355-66.

Swedenborg, B. (1979) The Multinational Operations of Swedish Firms: An Analysis of Determinants and Effects, Stockholm: IUI.

Weibull, J. W. (1988) 'Refinements of Subgame Perfection - Without Trembles', Bonn University Discussion Paper A-146.

- (1989) 'Interpersonal Consistency of Beliefs in Extensive-Form Games', IIES Seminar Paper No.433.

Werin, L. (1990) 'An Applied General Equilibrium Model of the Asset Markets in Sweden', in L. Bergman, D. W. Jorgenson and E. Zalai (eds) General Equilibrium Modeling and Economic Policy Analysis, Oxford: Basil Blackwell: 149-91.

Wihlborg, C. (1990) 'The Incentive to Acquire Information and Financial Market Efficiency', Journal of Economic Behavior and Organization, 13, June:347-65.

Wold, H. and Juréen, L. (1952) Demand Analysis: A Study in Econometrics, Stockholm: Almqvist and Wiksell.

\section{APPENDIX B: PROFESSORS OF ECONOMICS IN SWEDEN 1741-1989}

\section{References}

Andersson, A. (1897) Upsala Universitet 1872-1897 III (Uppsala University 1872-1897 III), Uppsala: Akademiska Boktryckeriet.

Annerstedt, C. (1912-14) Upsala Universitets historia III 1719-1792 (The history of Uppsala University III 1719-1792), Uppsala and Stockholm: Almqvist and Wicksell.

Liedman, S-E. (1986) Den synliga handen (The visible hand), Stockholm: Arbetarkultur.

Sveriges statskalender (The Swedish State Calendar), 1865-1989, Stockholm: Allmänna Förlaget.

Svenska män och kvinnor 1-8 (Swedish men and women 1-8), 1942-55, Stockholm: Albert Bonniers Förlag.

Svenskt biografiskt lexikon 1-26 (Swedish biographical encyclopedia 1-26), 1918-87, Stockholm: Albert Bonniers Förlag 1918-63, Svenskt biografiskt lexikon 1964-87.

Vem är det (Who's who), 1912-90, Stockholm: Norstedts.

Weibull, M. and Tegnér, E. (1868) Lunds universitets historia 1668-1868. Andra delen (The History of Lund University 1668-1868. Second part), Lund: Gleerups. 


\section{Notes and references}

\section{APPENDIX C: THE ROLE OF INSTITUTIONS}

Notes

1 This is a minimum estimate. It is possible to acquire the first degree in other ways as well.

2 See also Chapter 4.

3 A popular summary of the work of Lund economists in the 1980s can be found in Jonung (1990b).

4 During the formative period the Institute was primarily financed by grants.

\section{APPENDIX D: DOCTORAL THESES IN ECONOMICS 1895-} 1989

\section{Notes}

1 Many people have helped to make this list as complete and correct as possible. I would especially like to thank Gregor von Stryk, Swedish Institute for Social Research, who has assisted in much of the data collecting and Thomas Aurelius, Uppsala University, and Jan-Olof Friström, Lund University Library.

2 It could also be added that in a number of cases it has been difficult to obtain information on the subject of licentiate dissertations according to the old system, since the registers and minutes of the proceedings of the faculties are not complete. In some cases it has been possible to obtain the information from other sources. but not in all. 


\section{Bibliography}

Albrecht, J. and Axell, B. (1984) 'An Equilibrium Model of Search Unemployment', Journal of Political Economy, 92, 5:824-40.

Albrecht, J., Axell, B. and Lang, H. (1986) 'General Equilibrium Wage and Price Distributions', Quarterly Journal of Economics, 101, 4:687-706.

Alchian, A. A. and Demsetz, H. (1972) 'Production, Information Costs, and Economic Organization', American Economic Review, 62, December:777-95.

Alkin, M. C. (ed.) (1990) Debates on Evaluation, London: Sage.

Allardt, E., Lysgaard, S. and Bøttger Sørensen, A. (1988) Sociologin i Sverige (Sociology in Sweden), Uppsala: Swedish Science Press.

Anderson, J. (1989) 'The Evaluation of Research Training', in D. Evered and S. Harnett (eds) (1989) The Evaluation of Scientific Research, Chichester: Wiley: 93-113.

Andersson, Å. E., Anderstig, C. and Hårsman, B. (1990) 'Knowledge and Communications Infrastructure and Regional Economic Change', Regional Science and Urban Economics, 20, 3:359-76.

Andersson, $\AA .$, Kallio, M. and Seppälä, R. (1986) 'Systems Analysis for the Forest Sector', TIMS Studies in the Management Sciences 21:1-23.

Andersson, $\AA$. E. and Kuenne, R. E. (1986) 'Regional Economic Dynamics', in P. Nijkamp (ed.) (1986) Handbook of Regional and Urban Economics, Vol. I, Amsterdam: Elsevier: 201-53.

Argyris, C. and Schön, D. A. (1978) 'Organizational Learning', in C. Argyris and D. A. Schon Organizational Learning: A Theory of Action Perspective, Reading, MA: Addison-Wesley: 8-29.

Banks, F. E. (1976) The Economics of Natural Resources, New York: Plenum Press.

Beckmann, M. and Puu, T. (1990) Spatial Structures, Berlin: Springer-Verlag.

Bentzel, R. (1986) 'Nationalekonomi och ekonomisk historia' (Economics and Economic History), in Juridisk och samhällsvetenskaplig forskning, UHÄrapport 1986 25: 85-101.

- (1991) 'Economics at Uppsala from Berch to Lindahl/Palander - A Survey', in R. Bentzel, et al., Economics at Uppsala University, Uppsala: Department of Economics: 3-13.

Berger, P. L. and Luckmann, T. (1966) The Social Construction of Reality: $A$ Treatise in the Sociology of Knowledge, Garden City: Doubleday.

Bergman, L. (1988) 'Energy-Policy Modelling: A Survey of General Equilibrium Approaches', Journal of Policy Modeling, 10, 3:377-99. 


\section{Bibliography}

Bergman, L. and Lundgren, S. (1990) 'General Equilibrium Approaches to Energy Policy Analysis in Sweden', in L. Bergman, D. Jorgenson and E. Zalai (eds) General Equilibrium Modeling and Economic Policy Analysis, Oxford: Basil Blackwell: 351-82.

Bergström, C. and Rydqvist, K. (1990) 'The Determinants of Corporate Ownership: An Empirical Study on Swedish Data', Journal of Banking and Finance, 14, 2/3:237-53.

Björklund, A. and Persson-Tanimura, I. (1983) 'Youth Employment in Sweden', in B. G. Reubens (ed.) (1983) Youth at Work. An International Survey, Totowa, NJ: Rowman and Allanheld: 232-68.

Blaug, M. (1980) The Methodology of Economics or How Economists Explain, Cambridge: Cambridge University Press.

(1985) Great Economists since Keynes, Brighton: Wheatsheaf.

Blomquist, S. (1990) 'Nonconvex Preferences and Coherency for Labor Supply Models', Working Paper, Department of Economics, Princeton University.

Blomström, M. (1986a) 'Multinationals and Market Structure in Mexico', World Development, 14, 4:523-30.

- (1986b) 'Foreign Investment and Productive Efficiency: The Case of Mexico', Journal of Industrial Economics, 35, 1:97-110.

Blume, S. (1989) 'Contribution to the General Discussion II: Beyond Bibliometrics', in D. Evered and S. Harnett (eds) (1989) The Evaluation of Scientific Research, Chichester: Wiley: 217.

Bohm, P. (1984) 'Revealing Demand for an Actual Public Good', Journal of Public Economics, 24, 2:135-51.

- (1987a) 'Second Best', 'External Economies', and 'Lindahl on Public Finance', in J. Eatwell, M. Milgate and P. Newman (eds) (1987) The New Palgrave: A Dictionary of Economics, London: Macmillan, Vol. 2:261-3, Vol. 3:200-1, Vol. 4:280-3.

- (1987b) Social Efficiency - A Concise Introduction to Welfare Economics, (2nd edn), London: Macmillan.

Bohm, P. and Russell, C. S. (1985) 'Comparative Analysis of Alternative Policy Instruments', in A. V. Kneese and J. L. Sweeney (eds) (1985) Handbook of Natural Resource and Energy Economics, Vol. I, Amsterdam: North-Holland: 395-460.

Bromley, D. A. (1972) Physics in Perspective, Washington, DC: National Academy of Sciences.

Brownstone, D., Englund, P. and Persson, M. (1988a) 'A Micro-simulation Model of Swedish Housing Demand', Journal of Urban Economics, 23, 2:179-98.

(1988b) 'Tax Reform and Housing Demand: The Distribution of Welfare Gains and Losses', European Economic Review, 32, April:819-40.

Caldwell, B. J. (1982) Beyond Positivism: Economic Methodology in the Twentieth Century, London: Allen and Unwin.

Calmfors, L. (1977) 'Inflation in Sweden', in L. B. Krause and W. S. Salant (eds) (1977) Worldwide Inflation: Theory and Recent Experience, Washington: Brookings Institution: 493-544.

- (1978) Prices, Wages and Employment in the Open Economy, Monograph No. 10, Stockholm: IIES.

(ed.) (1990) Wage Formation and Macroeconomic Policy in the Nordic 
Countries, Stockholm and Oxford: SNS Förlag and Oxford University Press.

Calmfors, L. and Driffill, J. (1988) 'Bargaining Structure, Corporatism and Macroeconomic Performance', Economic Policy, 6, April: 14-61.

Carlson, S. (1980) 'Tidigare svensk företagsekonomi' (Early Swedish Business Administration), in L. Engwall (ed.) Företagsekonomins rötter, Lund: Studentlitteratur: $28-40$.

Carlson, B. and Jonung, L. (1989) 'Gustav Cassels artiklar i Svenska Dagbladet. Register 1903-1944' (Gustav Cassel's Articles in the Svenska Dagbladet 1903-1944), Meddelande från Ekonomisk-historiska institutionen, Lunds universitet. No. 62 (mimeo).

Carlsson, H. (1988) 'Time Consistency, Coordination and Forward Induction', Working Paper, University of Lund.

Cassel, G. (1941) I förnuftets tjänst (In the Service of Reason), Stockholm: Natur and Kultur.

Chen, H.-T. (1990) Theory-Driven Evaluations, Newbury Park, CA: Sage.

Coats, A. W. (1980) 'The Culture and the Economists: Some Reflections on Anglo-American Differences', History of Political Economy, 12, 4:588-609.

- (1985) 'The American Economic Association and the Economics Profession', Journal of Economic Literature, 23, 4:1697-1727.

Coats, A. W. and Colander, D. (1989) 'An Introduction to the Spread of Economic Ideas', in D. C. Colander and A. W. Coats (eds) The Spread of Economic Ideas, Cambridge: Cambridge University Press: 1-19.

Clower, R. W. (1989) 'The State of Economics: Hopeless but not Serious?', in D. C. Colander and A. W. Coats (eds) The Spread of Economic Ideas, Cambridge: Cambridge University Press: 23-9.

Colander, D. (1989a) 'The Invisible Hand of Truth', in D. C. Colander and A. W. Coats (eds) The Spread of Economic Ideas, Cambridge: Cambridge University Press: 31-6.

Colander, D. (1989b) 'Research on the Economics Profession', Journal of Economic Perspectives, 3, 4:137-48.

Cook, T. D. and Campbell, D. T. (1979) Quasi-Experimentation: Design and Analysis Issues for Field Settings, Chicago: Rand McNally.

Cuddington, J. T., Johansson, P.-O. and Löfgren, K.-G. (1984) Disequilibrium Macroeconomics in Open Economies, Oxford: Basil Blackwell.

Dahllöf, U. (1987) 'Akademiska avhandlingar vid Sveriges universitet och högskolor 1890-1939. En kompletterande sammanställning' (Academic Dissertations at Swedish Universities 1890-1939. A Supplementary Compilation), Uppsala: Department of Education.

- (1989) 'Doctoral Studies and Public Policies Affecting the Labour Market for Ph.D.s in Norway and Sweden', Scandinavian Journal of Educational Research, 33, 3:165-84.

Dahmén, E. (1950) Svensk industriell företagarverksamhet. Kausalanalys av den industriella utvecklingen 1919-1939 (Entrepreneurial Activity in Swedish Industry in the Period 1919-1939), Stockholm: IUI; with an English Summary.

Dahmén, E. and Mäler, K.-G. (1990) 'Environment, Natural Resources and Society', in K. Härnqvist and N.-E. Svensson (eds) (1990) Swedish Research in a Changing Society, Hedemora: Gidlunds förlag: 193-211. 


\section{Bibliography}

Danielsen, R. et al. (1988) Historia i belysuing (History in the light), Uppsala: Swedish Science Press.

Davis P. and Papanek G. (1984) 'Faculty Ratings of Major Economics Departments by Citations', American Economic Review, 74, March: 22530.

DiMaggio, P. J. and Powell, W. W. (1983) 'The Iron Cage Revisited: Institutional Isomorphism and Collective Rationality in Organizational Fields', American Sociological Review, 48, 2:147-60.

Ds Bo 1982:2, Byggforskningen - en översyn och utvärdering. Slutrapport från Byggforskningsutredningen, Stockholm: Bostadsdepartementet.

Ds 1989:43, Forskningens villkor $i$ omvärlden (The Conditions of Research Outside Sweden), Stockholm: Allmanna förlaget.

Edin, P.-A. and Zetterberg, J. (1989) 'Inter-industry Wage Differentials: Evidence from Sweden and a Comparison with the United States', Working Paper, Department of Economics, Uppsala University.

Eliassen, K. A. and Pedersen, M. N. (1984) Svensk samhällsorganisation och förvaltning. En inventering av svensk forskning (Swedish Social Organization and Public Administration. An Inventory of Swedish Research), Stockholm: HSFR.

Eliasson, G. (1988) 'Schumpeterian Innovation, Market Structure, and the Stability of Industrial Development', in H. Hanusch (ed.) (1988) Evolutionary Economics: Applications of Schumpeter's Ideas, Cambridge: Cambridge University Press: 151-99.

Elzinga, A. (1988) 'The Consequences of Evaluation for Academic Research', Science Studies, 1, December:5-14.

Englund, P. and Svensson, L. E. O. (1988) 'Money and Banking in a Cash-InAdvance Economy', International Economic Review, 29, 4:681-705.

Engwall, L. (1987) 'An American Dream. Postgraduate Research Training in the Social Sciences in Sweden', in Postgraduate Research Training in the Social Sciences, Copenhagen: International Federation of Social Science Organizations: $122-8$.

(forthcoming) Mercury Meets Minerva, London: Pergamon Press.

Engwall, G. and Engwall, L. (1990) 'Ingen skatt på stipendier' (No Tax on Scholarships), Upsala Nya Tidning, 18 September 1990, p. 2.

Ethier, W. and Horn, H. (1984) 'A New Look at Economic Integration', in H. Kierzkowski (ed.) (1984) Monopolistic Competition and International Trade, Oxford: Clarendon Press: 207-29.

Ethier, W. J. and Svensson, L. E. O. (1986) 'The Theorems of International Trade with Factor Mobility', Journal of International Economics, 20, February:21-42.

Evered, D. and Harnett, S. (eds) (1989) The Evaluation of Scientific Research, Chichester: Wiley.

Fägerlind, I. (1991) 'Utbildningsstandarden i Sverige 1970-1990 och produktivitetsutvecklingen' (The Quality of Education in Sweden 1970-1990 and Productivity Growth), in E. Wadensjö Arbetskraft, arbetsmarknad och produktivitet (The Labour Force, the Labour Market and Productivity), Stockholm: Allmanna förlaget: 225-56.

Fama, E. and Jensen, M. (1983) 'Separation of Ownership and Control', Journal of Law and Economics, 26, June:301-25. 
Farm, A. (1988) 'Cooperative Oligopolistic Pricing', European Journal of Political Economy, 4, 1:13-28.

Farm, A. and Weibull, J. (1987) 'Perfectly Flexible Pricing in a Homogeneous Market', Scandinavian Journal of Economics, 89, 4:487-95.

Flam, H. and Helpman, E. (1987a) 'Industrial Policy Under Monopolistic Competition', Journal of International Economics, 22, February:79-102.

- (1987b) 'Vertical Product Differentiation and North-South Trade', American Economic Review, 77, December:810-22.

Flood, L. R. (1985a) 'A Monte Carlo Comparison of the Maximum Likelihood and the Corrected OLS estimators for Tobit Models', Economics Letters, 19:155-63.

(1985b) 'Using Bootstrap to Obtain Standard Errors of System Tobit Coefficients', Economics Letters, 19:339-42.

- (1988) 'Effects of Taxes on Non-market Work', Journal of Public Economics, 36, 2:259-67.

Flood, L. R. and Tasiran, A. (1990) 'A Monte Carlo Comparison of System Tobit Estimators', Economics Letters, 33:249-54.

Førsund, F. and Hjalmarsson, L. (1983) 'Technical Progress and Structural Change in the Swedish Cement Industry 1955-1979', Econometrica, 51, 5:1449-67.

- (1987) Analysis of Industrial Structure: A Putty-Clay Approach, Stockholm: Almqvist \& Wiksell International.

Friedman, M. (1991) 'Old Wine in New Bottles', Economic Journal, 101, January:33-40.

Gårdlund, T. (1958) Knut Wicksell. Rebell $i$ det nya riket (Published in English as The Life of Knut Wicksell by Almqvist \& Wiksell in 1958), Stockholm: Bonniers.

Garfield, E. (1989) 'Journal Citation Studies. 50. Part 1. Introduction to the Core Journals of Economics', Current Contents, 21, 1:3-11.

Georghiou, L. G. (1989) 'Organization of Evaluation', in D. Evered and S. Harnett (eds). The Evaluation of Scientific Research, Chichester: Wiley: 1626.

Gerschenkron, A. (1968) Continuity in History and Other Essays, Cambridge, MA: Harvard University Press.

Gordon, M. D. (1984) 'How Authors Select Journals: A Test of the Reward Maximization Model of Submission Behavior', Social Studies of Science, $14,1: 27-43$.

Gottfries, N. (1986) 'Price Dynamics of Exporting and Import-Competing Firms', Scandina 'ian Journal of Economics, 88, 2:417-36.

Gottfries, N. and Horn, H. (1987) 'Wage Formation and the Persistence of Unemployment', Economic Journal, 97, December:877-84.

Government Bill 1981/82:106.

Government Bill 1986/87:80, Om forskning (On Research), Stockholm: Regeringskansliet.

Government Bill 1989/90:90, Om forskning (On Research), Stockholm: Regeringskansliet.

Graves, P. E., Marchand, J. R. and Thompson, R. (1982) 'Economics Departmental Rankings: Research Incentives, Constraints, and Efficiency', American Economic Review, 72, December:1131-41.

Grossman, G. and Horn, H. (1988) 'Infant-Industry Protection Reconsidered: 


\section{Bibliography}

The Case of Informational Barriers to Entry', Quarterly Journal of Economics, 103, 4:767-87.

Guba, E. G. and Lincoln, Y. S. (1989) Fourth Generation Evaluation, Newbury Park, CA: Sage.

Hägg, I. (1979) 'Reviews of Capital Investments: Empirical Studies', Finnish Journal of Business Economics, 28, 3:211-25.

Hamilton, C. (1985) 'Economic Aspects of Voluntary Export Restraints', in D. Greenaway (ed.) (1985) Current Issues in International Trade, London: Macmillan: 99-117.

(1986) 'An Assessment of Voluntary Restraints on Hong Kong Exports to Europe and the USA', Economica, 53, August:339-50.

Hamilton, C. and Svensson, L. E. O. (1983) 'On the Choice Between Capital Import and Labor Export', European Economic Review, 20, 1-3:167-92.

- (1984) "Do Countries" Factor Endowments Correspond to the Factor Contents in Their Bilateral Trade Flows?', Scandinavian Journal of Economics, 86, 1:84-97.

Handbooks in Economics, 1981-1989, Amsterdam: North Holland.

Hansson, I. and Stuart, C. (1985a) 'Tax Revenue and the Marginal Cost of Public Funds in Sweden', Journal of Public Economics, 27, August:331-53.

- (1985b) 'Progressive Taxation as Social Insurance and as Median-Voter Outcomes', Scandinavian Journal of Economics, 87, 3:487-99.

- (1989) 'Social Security as Trade Among Living Generations', American Economic Review, 79, December:1182-95.

Härnqvist, K. and Svensson, N.-E. (eds) (1990) Swedish Research in a Changing Society, Hedemora: Gidlunds förlag.

Hausman, J. A. (1985) 'Taxes and Labor Supply', in A. J. Auerbach and M. Feldstein (eds) (1985) Handbook of Public Economics, Volume I, Amsterdam: North-Holland: 213-63.

Hegeland, H. (1988) Skyddslingarna på Ekedalen (The Protegés at Ekedalen), Gothenburg: Tre Böcker.

Henriksson, R. G. H. (1990) Som Edström ville - hur IUI blev till (As Edström Wanted - How IUI was Founded), Stockholm: IUI.

Hermansson, J. and Rothstein, B. (1989) 'Politikens teser och vetenskapliga argument' (The Theses of Politics and Scientific Arguments), Statsvetenskaplig tidskrift, 92, 3:193-9.

Hey, J. D. and Winch, D. (1990) A Century of Economics: 100 Years of the Royal Economic Society and the Economic Journal, Oxford: Basil and Blackwell.

Hill, C. T. (1989) 'How Science Policies are Determined in the United States', in D. Evered ar i S. Harnett (eds) (1989) The Evaluation of Scientific Research, Chichester: Wiley: 221-9.

Hirsch, B. T., Austin, R., Brooks, J. and Moore, J. B. (1984) 'Economics Departmental Rankings: Comment', American Economic Review, 74, September:822-6.

Hirschman, A. O. (1964) 'The Paternity of an Index', American Economic Review, 54, September:761-2.

Holmlund, B., Löfgren, K.-G. and Engström, L. (1989) Trade Unions, Employment, and Unemployment Duration, Oxford: Clarendon Press.

Holmlund, B. and Zetterberg, J. (1989) 'International Evidence on Industry Wage Determination', Working Paper, Department of Economics, Uppsala University. 
Horn, H. (1983) Imperfect Competition in Models of Wage Formation and International Trade, Monograph No. 15, IIES, Stockholm.

Horn, H. and Persson, T. (1988) 'Exchange Rate Policy, Wage formation and Credibility', European Economic Review, 32, October:1621-36.

Hörngren, L. and Vredin, A. (1989) 'Exchange Risk Premia in a Currency Basket System', Welfwirtschaftliches Archiv, 125, 2:311-25.

Hull, D. L. (1988) Science as a Process. An Evolutionary Account of the Social and Conceptual Development of Science, Chicago: University of Chicago Press.

Irvine, J. (1989) 'Evaluation of Scientific Institutions: Lessons from a Bibliometric Study of UK Technical Universities', in D. Evered and S. Harnett (eds) (1989) The Evaluation of Scientific Research, Chichester: Wiley.

Jacobsson, and L. Lindbeck, A. (1969) 'Labor Market Conditions, Wages and Inflation - Swedish Experiences 1955-67', Swedish Journal of Economics, 71, 2:64-103.

Johansson, P.-O. (1982) 'Cost-Benefit Rules in General Disequilibrium', Journal of Public Economics, 18, June:121-37.

Johansson, P.-O. and Löfgren, K.-G. (1985) The Economics of Forestry and Natural Resources, Oxford: Basil Blackwell.

Johnson, H. G. (1973) 'National Styles in Economic Research: The United States, the United Kingdom, and Various European Countries', Daedalus, 102, 2:65-74.

- (1977) 'The American Tradition in Economics', Nebraska Journal of Economics and Business, 16, 3:17-26.

Jonung, C. (1984) 'Patterns of Occupational Segregation by Sex in the Labor Market', in G. Schmid and R. Weitzel (eds) (1984) Sex Discrimination and Equal Opportunity, Aldershot: Gower: 44-68.

Jonung, L. (ed.) (1990a) The Stockholm School of Economics Remembered (in preparation).

(ed.) (1990b) Nya fält för marknadsekonomin (New Fields for the Market Economy) (tillägnad Ingemar Ståhl), Stockholm: SNS förlag.

- (ed.) (1991a) The Stockholm School of Economics Revisited, Cambridge: Cambridge University Press.

(1991b) Swedish Economic Thought: Explorations and Advances, London: Routledge (forthcoming).

Jonung, L. and Laidler, D. (1988) 'Are Perceptions of Inflation Rational? Some Evidence from Sweden', American Economic Review, 78, 5:1080-7.

Jungenfelt, K. G. (1986) 'Intertemporal Aspects of Learning New Techniques', Scandinnvian Journal of Economics, 88, 1:157-87.

Jungenfelt, K. G. and Lindbeck, A. (1973) 'Economic Research in Sweden During the Post-war Period', in Social Science Research in Sweden, Stockholm: Scandinavian University Books: 9-22.

Kimberly, J. R. (1980) The Organizational Life Cycle, San Francisco: JosseyBass.

Kindleberger, C. P. (1989) 'How Ideas Spread Among Economists: Examples from International Economics', in D. C. Colander and A. W. Coats (eds.), The Spread of Economic Ideas, Cambridge: Cambridge University Press: 43-59.

Klamer, A. and Colander, D. (1990) The Making of an Economist, Boulder: 


\section{Bibliography}

Westview Press.

Klamer, A., McCloskey, D. N. and Solow, R. M. (eds) (1988) The Consequences of Economic Rhetoric, Cambridge: Cambridge University Press.

Klevmarken, A. N. (1974) 'Ekonometrins ställning i Sverige' (The Status of Econometrics in Sweden), Ekonomisk debatt, 2, 4:245-8.

(1981) On the Complete Systems Approach to Demand Analysis, Stockholm: Almqvist \& Wiksell International.

_ (1984) 'Household Market and Nonmarket Activities. The First Year of a Swedish Panel Study', Proceedings of the American Statistical Association, Business and Economic Statistics Section:52-7.

(1986) 'Collection Data for Micro Analysis: Experiences from the HUSPilot Study', in G. H. Orcutt, J. Merz and H. Quinke (eds) Microanalytic Simulation Models to Support Social and Financial Policy, Amsterdam: North-Holland: 369-95.

Knudtzon, E. J. (1976) Knut Wicksells tryckta skrifter 1868-1950 (Knut Wicksell's Published Works 1868-1950), Acta Universitatis Lundensis, Sectio I. Theologica, Juridica, Humaniora 25, Lund: Gleerups.

Kodama, F. (1989) 'Contribution to the Discussion', in D. Evered and S. Harnett (eds) (1989) The Evaluation of Scientific Research, Chichester: Wiley: 31 .

Kotlikoff, L., Persson, T. and Svensson, L. E. O. (1988) 'Social Contracts as Assets: A Possible Solution to the Time-Consistency Problem', American Economic Review, 78, 4:62-77.

Kuhn, T. S. (1962) The Structure of Scientific Revolutions, Chicago: Chicago University Press.

Lakatos, 1. (1978) The Methodology of Scientific Research Programmes. Philosophical Papers. Vols. 1-2, Cambridge: Cambridge University Press.

Landgren, K.-G. (1957) Economics in Modern Sweden, Washington: Library of Congress (Translation from the Swedish by Paul Gekker).

Latour, B. (1987) Science in Action, Milton Keynes: Open University Press.

Leijonhufvud, A. (1973) 'Life Among the Econ' Western Economic Journal, 11, September:327-37; reprinted as Chapter 12 in Leijonhufvud, A. (1981) Information and Coordination. Essays in Macroeconomic Theory, New York: Oxford University Press.

Lincoln, Y. S. and Guba, E. G. (1985) Naturalistic Inquiry, Beverly Hills, CA: Sage.

Lindbeck, A. (1971) The Political Economy of the New Left: An Outsider's View, New York: Harper \& Row.

(ed.) (1979) Inflation and Employment in Open Economies, Amsterdam: North-Holland.

- (1990) 'Intarnationalization Process and National Economic Policies', in K. Härnqvist and N. E. Svensson (eds) (1990) Swedish Research in a Changing Society, Hedemora: Gidlunds förlag: 129-39.

Lindbeck, A. and Snower, D. J. (1988) The Inside-Outside Theory of Employment and Unemployment, Cambridge, MA and London: MIT Press.

Lindbeck, A. and Weibull, J. W. (1986) 'Intergenerational Aspects of Public Transfers, Borrowing, and Debt', Scandinavian Journal of Economics, 88, 1:239-267. 
- (1987) 'Balanced-Budget Redistribution as the Outcome of Political Competition', Public Choice, 52, 3:273-97.

- (1988a) 'Altruism and Time Consistency: The Economics of Fait Accompli', Journal of Political Economy, 96, 6:1165-82.

- (1988b) 'Welfare Effects of Alternative Forms of Public Spending', European Economic Review, 32, January:101-27.

Lindgren, B. and Persson, U. (1989) 'The Cost-Effectiveness of a New Antihypertensive Drug, Doxazosin', Current Therapeutic Research, 45, May:738-60.

Line, M. B. (1979) The Structure of Social Science Literature as Shown by Citations, Bath: DISISS, Research Reports Series A No.3, Bath University Library.

Lodahl, J. B. and Gordon, G. (1972) 'The Structure of Scientific Fields and the Functioning of University Graduate Departments', American Sociological Review, 37, February:57-72.

Lodge, D., 1985, Small World, Harmondsworth, Middlesex: Penguin (first published by Martin Secker and Warburg in 1984).

Löfgren, K.-G. (1991) 'Macroeconomic Model Building in Sweden - An Incomplete Survey', Scandinavian Journal of Economics, 93, 2:331-7.

Löfgren, K.-G., Bångman, G. and Wiberg, A. (1986) 'The Supply of Roundwood and Taxation', in $\AA$. Anderson, M. Kallio and R. Seppälä Systems Analysis in Forestry and Forest Industries, TIMS Studies in the Management Sciences 21, Amsterdam: North Holland: 227-43.

Lotka, A. J. (1926) 'The Frequency Distribution of Scientific Productivity', Journal of the Washington Academy of Sciences, 16, 12:317-23.

Lovell, M. C. (1973) 'The Production of Economic Literature: An Interpretation', Journal of Economic Literature, 11, 1:27-55.

Lundberg, E. (1953) Konjunkturen och ekonomisk politik (Business Cycles and Economic Policy), Stockholm: SNS.

(1984) Kriserna och ekonomerna (The Crises and the Economists), Stockholm: Liber.

Luukkonen-Gronow, T. (1989a) 'The Impact of Evaluation Data on Policy Determination', in D. Evered and S. Harnett (eds) (1989) The Evaluation of Scientific Research, Chichester: Wiley: 234-46.

- (1989b) 'Contribution to the General Discussion II: Beyond Bibliometrics', in D. Evered and S. Harnett (eds) (1989) The Evaluation of Scientific Research, Chichester: Wiley: 216.

Lybeck, J. A. (1984) 'A Comparison of the Dynamic Properties of Five Nordic Macroeconomic Models', Scandinavian Journal of Economics, 86, 1:35-51.

Lyttkens, C. H. (1988) “'Workers" Compensation and employees' Safety Incentives in Sweden', International Review of Law and Economics, 8, 2:181-5.

McCain, K. W. (1986) 'Cocited Author Mapping as a Valid Representation of Intellectual Structure', Journal of the American Society for Information Science, 37, 3:111-22.

McCloskey, D. N. (1983) 'The Rhetoric of Economics', Journal of Economic Literature, 21, June:481-517.

- (1986) The Rhetoric of Economics, Brighton: Wheatsheaf.

- (1990) If You're so Smart. The Narrative of Economic Expertise, 


\section{Bibliography}

Chicago: Chicago University Press.

Mäler, K.-G. (1974) Environmental Economics: a Theoretical Inquiry, Baltimore: Johns Hopkins University Press.

- (1990) 'International Environmental Problems', Oxford Review of Economic Policy, 6, 1:80-108.

Malinvaud, E. (1985) 'The Identification of Scientific Advances in Economics', in T. Hägerstrand, (ed.) The Identification of Progress in Learning, Cambridge: Cambridge University Press: 167-83.

(1991) 'The Next Fifty Years', Economic Journal, 101, January:64-8.

March, J. G. and Olsen, J. P. (1976) Ambiguity and Choice in Organizations, Bergen: Universitetsforlaget.

Markusen, J. and Svensson, L. E. O. (1985) 'Trade in Goods and Factors with International Differences in Technology', International Economic Review, 26, February:175-92.

Marion, N. P. and Svensson, L. E. O. (1984) 'World Equilibrium with Oil Price Increases: An Intertemporal Analysis', Oxford Economic Papers, 36, March:86-102.

Mitroff, I. (1974) The Subjective Side of Science. A Philosophical Inquiry into the Psychology of the Apollo Moon Scientists, Amsterdam: Elsevier.

Myrdal, G. (1927) Prisbildningsproblemet och föränderligheten (The Problem of Price Formation and the Variability), Uppsala: Almqvist \& Wiksell.

Narin, F. (1987) 'Bibliometric Techniques in the Evaluation of Research Programs', Science and Public Policy, 14, 2:99-106.

Neidhardt, F. (1988) Selbststeuerung in der Forschungsförderung. Das Gutachterwesen der DFG, Opladen: Westdeutscher Verlag.

Newlon, D. H. (1989) 'The Role of NSF in the Spread of Economic Ideas', in: D. C. Colander and A. W. Coats (eds) The Spread of Economic Ideas, Cambridge: Cambridge University Press: 195-228.

NFR (1981) 'International Evaluations of Research Projects Supported by the Swedish Natural Science Research Council. Summary of Reports, Achievements and Criticisms, 1977-1980', Stockholm: Swedish Natural Science Research Council.

Nyquist, H. (1991) 'Optimal Designs of Discrete Response Experiments in Contingent Valuation Studies', Review of Economics and Statistics (forthcoming).

Ohlin, B. (1924) Handelns teori (The Theory of Trade), Stockholm: Centraltryckeriet.

Ohrström, L. (1991) Research. The Swedish Approach, Stockholm: The Swedish Institute.

Olsson, U. (1989) 'Att . . befrämja affärsverksamhetens höjande i vårt land' (To ... Promote the Raising of Business Activity in Our Country), Skrift till Handelshögskolans i Stockholm 80-årsjubileum den 1 oktober 1989, Handelshögskolan, Stockholm.

Pasinetti, L. (1985) 'Comment on E. Malinvaud's Paper', in T. Hägerstrand (ed.), The Identification of Progress in Learning, Cambridge: Cambridge University Press: 183-6.

Pedersen, K. M. (1977) 'A Proposed Model for Evaluation Studies', Administrative Science Quarterly, 22, June:306-17.

Pelikan, P. (1989) 'Evolution, Economic Competence, and the Market for 
Corporate Control', Journal of Economic Behavior and Organization, 12, 3:279-303.

Pencavel, J. (1991) 'Prospects for Economics', Economic Journal, 101, January:81-7.

Persson, M., Persson, T. and Svensson, L. E. O. (1987) 'Time Consistency of Fiscal and Monetary Policy', Econometrica, 55, 6:1419-31.

Persson, O. (1986) 'Svensk forskning 1973-84 - Artikelproduktion och citeringar' (Swedish Research 1973-84 - Article Production and Citations), Bibliometriska notiser, 2, 2:1-2.

Persson, O., Stern, P., Holmberg, K.-G. (1990) BIBMAP: A Toolbox for Mapping the Structure of Scientific Literature, Paper presented at the International Conference of Scientific and Technology Indicators: Representations of Science and Technology, Bielefeld, Germany 10-12 June 1990.

Persson, T. (1982) Studies of Alternative Exchange Rate Systems: An Intertemporal General Equilibrium Approach, Monograph No. 13, IIES, Stockholm.

Persson, T. and Svensson, L. E. O. (1983) 'Is Optimism Good in a Keynesian Economy?', Economica, 50, August:291-300.

- (1984) 'Misperceptions, Rigidity and Welfare', European Economic Review, 25, August:387-99.

- (1985) 'Current Account Dynamics and the Terms of Trade: HarbergerLaursen-Metzler Two Generations Later', Journal of Political Economy, 93, February:43-65.

Persson, T. and Tabellini, G. (1990) Macroeconomic Policy Credibility and Politics, London and New York: Harwood Academic Publishers.

Persson, U., Montgomery, F., Karlsson, A. and Lindgren, B. (1988) 'How Far Does Prophylaxis Against Infection in Total Joint Replacement Offset Its Cost?', British Medical Journal, 296, January:99-102.

Phillips, D. (1989) 'Contribution to the General Discussion II: Beyond Bibliometrics', in D. Evered and S. Harnett (eds) (1989) The Evaluation of Scientific Research, Chichester: Wiley: 215.

Portes, R. (1987) 'Economics in Europe', European Economic Review, 31, August:1329-40.

Puu, T. (1979) The Allocation of Road Capital in Two-Dimensional Space, Amsterdam: North Holland.

- (1990) 'Några reflexioner över nationalekonomin idag' (Some Reflections on Economics Today), in K. Fridjonsdottir (ed) Svenska samhällsvetenskaper (Swedish Social Sciences), Stockholm: Carlssons: 109-12.

- (1991) 'Tord Palander and the Uppsala Milieu', in R. Bentzel, Economics at Uppsala University, Uppsala: Department of Economics: 99-105.

Radetzki, M. (1982) 'Has Political Risk Scared Mineral Investment away from the Deposits in Developing Countries?' World Development, 10, 1:3948.

- (1989a) A Guide to Primary Commodities in the World Market, Oxford: Basil Blackwell.

- (1989b) 'Precious Metals: The Fundamental Determinants of their Price Behaviour', Resources Policy, 15, 3:194-208.

Radetzki, M. and Van Duyne, C. (1984) 'The Response of Mining Investment to a Decline in Economic Growth: The Case of Copper in the 1970s', Journal of Development Economics, 15, May-June-August:19-45. 


\section{Bibliography}

Sandelin, B. (ed.) (1991) The History of Swedish Economic Thought, London: Routledge.

Schmid, G. and Weitzel, R. (eds) (1984) Sex Discrimination and Equal Opportunity, Aldershot: Gower.

Scott, P. (1991) Higher Education in Sweden - A Look from the Outside, Stockholm: UHÄ and the 1989 Government Committee on Higher Education.

Siven, C.-H. (1985) 'The End of the Stockholm School', Scandinavian Journal of Economics, 87, 4:577-93.

Skogh, G. (1982) 'Public Insurance and Accident Prevention', International Review of Law and Economics, 2, 1:67-80.

- (1989) 'The Transaction Costs Theory of Insurance: Contracting Impediments and Costs', Journal of Risk and Insurance, 56, 4:726-32.

Skogh, G. and Stuart, C. (1982) 'A Contractarian Theory of Property Rights and Crime', Scandinavian Journal of Economics, 84, 1:27-40.

Social Science Research in Sweden, 1973, Stockholm: Scandinavian University Books.

Södersten, B. (1980) International Economics, (2nd end), London: Macmillan.

Solow, R. (1990) 'My Evolution as an Economist', in W. Breit and R. W. Spencer (eds), Lives of the Laureates, Cambridge, MA: MIT Press: 181202.

SOU 1966:67, Forskarutbildning och forskarkarriär (Research Training and Research Careers). Betänkande avgivet av 1963 års forskarutredning, Stockholm: Ministry of Education.

SOU 1966:68, Forskarutbildning och forskarkarriär (Research Training and Research Careers). Bilagor (Supplements), Stockholm: Ministry of Education.

SOU 1975:26, Forskningsråd (Research Councils), Stockholm: Utbildningsdepartementet.

SOU 1981:29, Forskningens framtid. Forskning och forskarutbildning $i$ högskolan (The Future of Research. Research and Research Training at the University). Betänkande av Utredningen om forskningens och forskarutbildningens situation $\mathrm{i}$ den nya högskolan, Stockholm: Ministry of Education.

SOU 1989:30, Professorstillsättning. En översyn av proceduren vid tillsättning av professorstjänster (Appointment of Professors. An Overview of the Procedure for Appointing Professors), Stockholm: Ministry of Education.

SOU 1991:23, Ett nytt BFR - byggforskningen på 90-talet (A New BFR Building Research in the Nineties), Stockholm: Bostadsdepartementet.

Statistiska Meddelanden N14SM9001, 1990, Nationalräkenskaper 1980-1990 (National Accounts 1980-1990), Orebro: Statistics Sweden.

Stenkula, P. (1985) Tre studier över resursanvändningen $i$ högskolan (Three Studies of Resource Use in Higher Education), Lund Economic Studies 36, Lund (thesis).

- (1986) Produktions-, kostnads- och produktivitetsutveckling inom den offentligt finansierade utbildningssektorn 1960-1980 (The Development of Production, Costs and Productivity in the Publicly Financed Educational Sector 1960-1980), Stockholm: Finansdepartementet (DsFi 1986: 17).

Stern, P. (1990) 'Vetenskapens kognitiva landskap - en bibliometrisk studie av 
svensk nationalekonomi' (The Cognitive Landscape of Science - A Bibliometric Study of Swedish Economics), Bibliometriska rapporter, No. 3, Umeå: Inforsk, Dep of Sociology, Umeå University.

Stigler, G. and Friedland, C. (1979) 'The Pattern of Citation Practices in Economics', History of Political Economy, 11, 1:1-20.

Stigler, G. J. (1982) The Economist as Preacher and Other Essays, Chicago: Chicago University Press.

- (1984) 'Economics - The Imperial Science?', Scandinavian Journal of Economics, 86, 3:301-13.

Svennilson, I. (1938) Ekonomisk planering (Economic Planning), Uppsala: Almqvist \& Wiksell (thesis).

Svensson, L. E. O. (1980) 'Effective Demand and Stochastic Rationing', Review of Economic Studies, 47, 2:339-55.

(1984) 'Walrasian and Marshallian Stability', Journal of Economic

Theory, 34, December:371-9.

- (1985) 'Money and Asset Prices in a Cash-in-Advance Economy', Journal of Political Economy, 93, October:919-44.

_- (1986) 'Sticky Goods Prices, Flexible Asset Prices, Monopolistic Competition, and Monetary Policy', Review of Economic Studies, 53, July:385405.

Svensson, L. E. O. and Razin, A. (1983) 'The Terms of Trade and the Current Account: The Harberger-Laursen-Metzler Effect', Journal of Political Economy, 91, February:97-125.

Svensson, L.-G. (1983) 'Large Indivisibles: An Analysis with Respect to Price Equilibrium and Fairness', Econometrica, 51, 4:939-54.

- (1988) 'Fair Wages when Individual Choice Sets are Incomplete - An Application of a Model with Indivisibilities', Scandinavian Journal of Economics, 90, 4:563-73.

- (1989) 'Fairness, the Veil of Ignorance and Social Choice', Social Choice and Welfare, 6, 1:1-17.

Svensson, L.-G. and Weibull, J. W. (1984) 'Stability and Efficiency from a Neo-Keynesian Viewpoint', Journal of Economic Dynamics and Control, 7, September:349-62.

- (1986) 'An Upper Bound on Optimal Income Taxes', Journal of Public Economics, 30, July:165-81.

- (1987) 'Constrained Pareto-Optimal Taxation of Labour and Capital Incomes', Journal of Public Economics, 34, December:355-66.

Swedberg, R. (1988a) 'De nya doktorsavhandlingarna i sociologi 1969-1986' (The New Doctoral Theses in Sociology 1969-1986), in E. Allardt, S. Lysgaard and A. Bøttger Sørensen (1988) Sociologin i Sverige (Sociology in Sweden), Uppsala: Swedish Science Press: 144-79.

(1988b) 'Rörligheten bland svenska sociologer' (Mobility among Swedish Sociologists), in E. Allardt, S. Lysgaard and A. Bøttger Sørensen, Sociologin $i$ Sverige (Sociology in Sweden), Uppsala: Swedish Science Press: $279-87$.

Swedenborg, B. (1979) The Multinational Operations of Swedish Firms: An Analysis of Determinants and Effects, Stockholm: IUI.

Thurgood, D. H. and Weinman, J. M. (1989) Summary Report 1988. Doctorate Recipients from United States Universities, Washington: National Academy Press. 


\section{Bibliography}

(1990) Summary Report 1989: Doctorate Recipients from United States Universities, Washington: National Academy Press.

Tuckman, H., Coyle, S. and Bae, Y. (1990) On Time to the Doctorate. A Study of the Increased Time to Complete Doctorates in Science and Engineering, Washington: National Academy Press.

UHÄ Report 1980:16, 1981:18, 1982:17, 1983:8, 1984:10, 1985:5, 1986:15, 1988:9, 1989:7, 1990:3 and 1991:11.

van Raan, A. F. J. (1989) 'Evaluation of Research Groups', in D. Evered and S. Harnett (eds) (1989) The Evaluation of Scientific Research, Chichester: Wiley: 169-83.

Wadensjö, E. (1991) 'Högre utbildning och inkomster' (Higher Education and Earnings), in E. Wadensjö Arbetskraft, arbetsmarknad och produktivitet (The Labour Force, the Labour Market and Productivity), Stockholm: Allmanna förlaget: $257-84$.

Weibull, J. (1988) 'Refinements of Subgame Perfection - Without Trembles', Bonn University Discussion Paper A-146.

- (1989) 'Interpersonal Consistency of Beliefs in Extensive-Form Games', IIES Seminar Paper No.433.

Weinberg, A. M. (1963) 'Criteria for Scientific Choice', Minerva, 1, 2:159-71.

Werin, L. (1990) 'An Applied General Equilibrium Model of the Asset Markets in Sweden', in L. Bergman, D. W. Jorgenson and E. Zalai (eds), General Equilibrium Modeling and Economic Policy Analysis, Oxford: Basil Blackwell: 149-91.

Wihlborg, C. (1990) 'The Incentive to Acquire Information and Financial Market Efficiency', Journal of Economic Behavior and Organization, 13, June:347-65.

Wold, H. and Juréen, L. (1952) Demand Analysis: A Study in Econometrics, Stockholm: Almqvist \& Wiksell.

Ysander, B.-C. (1990) 'Varför är nationalekonomer så högfärdiga? Särdrag, problem och utvecklingsmöjligheter i svensk nationalekonomisk forskning' (Why are Economists so Stuck-Up? Distinguishing Features, Problems and Opportunities for Development in Swedish Economic Research), in K. Fridjonsdottir (ed.) Svenska samhällsvetenskaper (Swedish Social Sciences), Stockholm: Carlssons: 99-108.

Zetterblom, G. (1986) 'Postgraduate Education in Sweden: Reforms and Results', European Journal of Education, 21, 3:261-73.

—_ (1988) 'Forskarutbildningen - underlag för 1990 års forskningsproposition' Research Training - Basic Information for the 1990 Government Proposition on Research), UḦ̈-rapport 1989:7, Bilaga nr 18.

Ziolkowski, T. (1990) 'The Ph.D. Squid', American Scholar, 59, 2:177-95. 


\section{Glossary}

Arbetslivscentrum (ALC)

Arbetsmarknadsdepartementet

Arbetsmarknadsstyrelsen (AMS)

Byggforskningsrådet (BFR)

\section{CERUM}

disputation

docent

doktorandtjänst

doktorsexamen

doktorsgrad

Ekonomiska Forskningsinstitutet (EFI)

Ekonomiska rådet

Energiforskningsnämnden (EFN)

Expertgruppen för arbetsmarknadspolitiska utvärderingsstudier (EFA)

Fackföreningsrörelsens
Centre for Working Life

Ministry of Labour Labour Market Board Swedish Council for Building Research

Centre for Regional Studies at Umeå University

thesis defence

a competence usually corresponding to two Ph.D. theses; formerly also a research position with limited teaching duties which could be held for six years

graduate fellowship involving a small amount of teaching and social security benefits

$\mathrm{Ph} . \mathrm{D}$. degree in the new system $\mathrm{Ph} . \mathrm{D}$. degree in the old system Economic Research Institute at the Stockholm School of Economics Economic Council of the Ministry of Finance

Energy Research Commission Delegation for Labour Market Policy Research

Trade Union Institute 


\section{Glossary}

institut för ekonomisk

forskning (FIEF)

fakultetsopponent

Finansdepartementet

folkhögskola

forskarassistent

Forskningsrådsnämnden (FRN)

grundexamen

Göteborgs universitet (GU)

Handelshögskolan (HHS)

handledare

Humanistisk-Samhällsvetenskapliga forskningsrådet

(HSFR)

högskoleadjunkt

högskolelektor

Industriens utredningsin-

stitut (IUI)

Institutet för hälso- och

sjukvårdsekonomi (IHE)

Institutet för interna-

tionell ekonomi (IIES)

Institutet för social

forskning (SOFI)

Konjunkturinstitutet

(KI)

Kungl. Vetenskapsakademien

(KVA)

Landsorganisationen (LO)

licentiatexamen

Lunds universitet (LU)

Nationalekonomiska

föreningen for Economic Research

external examiner for a Ph.D.

thesis

Ministry of Finance

community college

four-year post-doctoral research position with limited teaching duties

Coordinating Board of the

Swedish Research Councils

first academic degree

Gothenburg University

Stockholm School of Economics

thesis supervisor/adviser

Swedish Council for Research

in the Humanities and the

Social Sciences

lecturer without $\mathrm{Ph} . \mathrm{D}$.

competence

lecturer with Ph.D. competence

Industrial Institute for

Economic and Social Research

Institute for Health

Economics at Lund University

Institute of International

Economic Studies at Stockholm

University

Swedish Institute for

Social Research

National Institute of Econo-

mic Research

Swedish Royal Academy of

of Sciences

Swedish Confederation of

Labour

a degree corresponding to half a

$\mathrm{Ph}$.D.; formerly closer to a

Ph.D.

Lund University

Swedish Economics Assocation 
Glossary 277

professor

Riksbankens Jubileumsfond (RJ)

sakkunniga

sakkunnigutlätande sammanläggningsavhandling

SAREC

Skogs- och Jordbrukets

Forskningsråd (SJFR)

Skogshögskolan

Socialvetenskapliga forskningsrådet (SFR)

Statens Offentliga

Utredningar (SOU)

Statistiska Centralbyrån

(SCB)

Stockholms högskola

Stockholms universitet (SU)

Stockholmsskolan

Studieförbundet Näringsliv

och Samhälle (SNS)

Sveriges Lantbruksuni-

versitet (SLU)

Umeå universitet (UmU)

Universitets- och Högskole-

ämbetet (UHÄ)

universitetslektor

utbildningsbidrag

Uppsala universitet (UU) occupant of a chair

Bank of Sweden Tercentenary

Foundation

committee evaluating candidates

for a chair

evaluation committee report

thesis in the form of a collection

of articles

Swedish Agency for Research

Cooperation with Developing

Countries

Swedish Council for Research

in Forestry and Agriculture

College of Forestry

The Swedish Council for

Social Research

Government Commission

Reports

Statistics Sweden - Sweden's

central bureau of statistics

College of Stockholm

(predecessor of Stockholm

University)

Stockholm University

The Stockholm School

Centre for Business

and Policy Studies

Swedish Agricultural

University

Umeå University

Office of Swedish

Higher Education

lecturer

graduate fellowship with no

teaching duties and no social

security benefits

Uppsala University 


\section{Index}

age: and earnings of economics doctors, 96, 97, 100; of Ph.D. students, 80-3, 85; of professors at first appointment, 34, 35

Åkerman, G., 25, 37

Åkerman, J., 198

Albrecht, J., 141

Alchian, A. A. 3

Alkin, M. C., 9, 235n

Allardt, E., 4, 118

Anderson, J., 234n

Andersson, Ä. E., 116, 135

Andersson, K., 26

Anderstig, C., 135

animosity between professors, 37-8

applied research-financing bodies, 51-2, 59

Argyris, C., 18

Artle, R., 35

Arvidson, G., 26

Axell, B., 140-1

Bagge, G., 24, 37, 38, 40, 46, 77, 87 Bank of Sweden Tercentenary

Foundation, 51, 59

Banks, F. E., 134

basic research-financing bodies, 50-1

Beckmann, M., 135

Bentzel, R., 4-5, 9, 26

Berch, A., 189

Berger, P. L., 17

Bergman, L., 27, 143

Bergström, R., 139, 140, 142

bibliometrics, 14, 106-16, 234n

Blaug, M., 4

Blomquist, S., 138
Blomström, M., 138

Blume, S., 5, 10

Bohm, P., 26, 138

Bohman, G., 45

Brock, F., 24, 74

Bromley, D. A. 8

Brownstone, D., 139

Burenstam Linder, S., 27, 40, 117

Caldwell, B. J., 4

Calmfors, L., 26, 27, 132, 136, 141

Campbell, D. T., 5

career path system, $16,150,154$, $166-7,173-4,177-8$

Carlsson, H., 143

Cassel, G., 19, 20, 23, 24, 37, 38, 39 , 45

Cassel, M., 84

Centre for Regional Studies (CERUM), 147

Chen, H.-T., 6, 234n

citation networks, 116-18

Clower, R. W., 5

Coats, A. W., 5, 12, 39

Colander, D., 4, 5, 12, 33, 77, 233n

College of Forestry (Umea), 147

College of Gothenburg, 20 see also

Gothenburg University College of

Stockholm: 20; see also

Stockholm University

competition in research, 174-5

Cook, T. D., 5

cooperative networks, 16

Council for Research in the Natural

Sciences (NFR), 4

Cuddington, J. T., 141

Dahllöf U., 74 
Dahmén, E., 26, 37, 169

Danielsen, R., 4

Davidson, D., 19, 20, 23, 36

defence research, 26

degrees, see licentiate degrees; Ph.D. degrees

Delegation for Labour Market

Policy Research (EFA), 52

Demsetz, H., 3

development economics research, 137,138

DiMaggio, P. J., 18

doctoral, see Ph.D.

doctors of economics: earnings of, 96, 97, 98-100, 103, 165-6; labour market for 94-102, 145-6; private sector employment, 95, 146;

public sector employment, 95 , 146; teaching by, 166-7, 173-4

Driffill, J., 141

earnings: 96-100; and age of economics doctors, 96, 97, 100; of licentiate degree recipients, 96,97 ; of Ph.D. recipients, 96, 97, 98 $100,103,165-6$; in private sector, 96,97 ; in public sector, 96,97 ; of women economists, 96, 97, 99, 103

econometrics research, 28, 139-40, 156

Economic Council, 148, 151, 154, 158

economic history research, 27-8

Economic Research Institute (EFI), 147

economic statistics research, 28

Edin, P.-A., 133, 140

education research, 26

EFO-model, 27

Ekonomisk Debatt, 40-1

Ekonomisk Tidskrift, 20, 41, 46

Eliassen, K. A., 4

Eliasson, G., 143

emigration of professors, 35-6

employment research, see labour economics energy economics research, 27

Energy Research Commission, 52

Englund, P., 27, 138, 142
Engström, L., 132

Engwall, L., 3

environmental economics research, $26,133-5$

Erlander, T., 45

Ethier, W., 136

evaluation process, 8-11

evaluators, selection of, 9

experimental approach to

evaluations, 5-6

external examiners, see faculty opponents

external research grants, 50-2, $59-62,66,172$

extramural activities of professors, 39-45

faculty grants, 49-50, 54-9, 66

faculty opponents, 88-91, 103

Fägerlind, I., 79

Fama, E., 3

Farm, A., 142

Federation of Industry, 61

fellowships: overseas: $183-4$; see also scholarships

financial economics research, 27, 142

financial incentives, 165-6, 172, 173

financial support: for postgraduates 78, 79, 164-5, 184-5; see also funding; resource allocation

fiscal policy research, 141

Flam, H., 136

Flood, L., 140, 143

foreign countries, employment opportunities for economists in, 146

Forslund, A., 133

Försund, F., 143

France, 107

Friedman, M., 18, 236n

frontier research, 157

funding: tied, 156, 158; see also financial support; resource allocation

Garfield, E., 110 generalizability of evaluations, 6

Georghiou, L. G., 233n

Germany, West, 107

Gordon, G., 18 


\section{Index}

Gordon, M. D., 111

Gothenburg University: 20, 26, 133,

138, 143, 165; Ph.D. degrees, 73;

Ph.D. students, 76, 80; Ph.D.

theses, 92, 93; research grants, 55,

$56,59,61,63,64,66$; research

profile, $119,120,121$

Gottfries, N., 132, 142

grants, see research grants

Graves, P. E., 5

gross national product (GNP), grant ratio, 57-8

Grossman, G., 136

Guba, E. G., 5, 8, 235n

Hägg, I., 17

Hamilton, C., 136, 137

Hammarskjöld, D., 24, 25, 38

Handbooks in Economics, 111, 115

Hansen, B., 26, 35

Hansson, I., 27, 139

Harberger-Laursen-Metzler (HLM) effect, 137

Härsman, B., 135

Hausman, J. A., 138

health economics research, 143, 152

Heckscher, E., 19, 20, 23, 24, 25, 36, $38,39,40,45,197$

Hegeland, H., 40, 77-8

Helpman, E., 136

Hill, C. T., 3, 234n

Hirsch, B. T., 5

Hjalmarsson, L., 143

Höglund, B., 37

Holmberg, K.-G., 123

Holmlund, B., 26, 132, 133

Horn, H., 132, 136, 141

Hörngren, L., 142

housing policy research, 26

Hull, D. L., 16, 17, 233n

immigrant economists, 97, 99, 103

inbreeding in university system, $149-50,169,173,178$

incentives: 12, 34-5, 164-8, 173;

financial, 165-6, 172, 173

income, see earnings

Industrial Institute for Economic and Social Research (IUI), 9, 78, 138. 143. 147-8. 153. 158

Institute of Health Economics

(IHE), 143, 147, 152, 153

Institute for International Economic

Studies (IIES): 9, 26, 27, 78, 131, $132,135-7,147,151-2,158,171$, $174,246 \mathrm{n}$; publication activity, 125; research grants, $55,56,58$, $59,61,63,64,66,199$; research profile, $119,122,123$

institutions: role of, 196-9; selection of, 1-9

intensive courses, 181-3

international communication: 36 , 45-7; see also publication, international

international economics research, $27,135-8,153$

internationalization of Swedish economics, $15,171-2$

interregional economics research, 135

intramural activities of professors, 33-9

Irvine, J., 3

Jacobsson, L., 131

Jensen, M., 3

Johansson, A., 24, 25

Johansson, B., 116

Johansson, P.-O., 141

Johnson, H. G., 19

Jonung, C., 133

Jonung, L., 26, 142

Jöreskog, K. G., 116

Journal of Economic Literature, $106,121,123$

journals: citations of Swedish economists in, 116-18; language of articles in, 106, 109; publication in, 104-26, 171-2; selection of, 109-11

Jungenfelt, K., 9, 26, 143

Juréen, L., 140

Kerman, G., 24, 37, 77, 87

Kimberly, J. R., 8

Kindleberger, C. P., 235n

Klamer, A., 4, 33, 77

Klevmarken, A., 133, 140, 143

Kock, K., 24, 43, 84, 87, 103

Kodama. F. 235n 
Index 281

Kotlikoff, L., 141

Kuenne, R. E., 135

Kuhn, T. S., 16

labour economics research, 27 , $130-3,152,153$

labour market: for doctors of economics, 94-102, 145-6; for professors, 20-8

Laidler, D., 142

Lakatos, I., 4

Lang, H., 141

language: of journal articles, 106, 109; of theses, 87-8, 103

Lehrstuhl tradition, 11

less developed countries, research on, 137,138

library facilities, 163

licentiate degrees, 68-9, 70, 71, $74-5,81,96,97,98,100$

Lincoln, Y. S., 5, 8, 235n

Lindahl, E., 24, 25, 36, 38, 87

Lindbeck, A., 9, 26, 44, 45, 109, $117,131,132,136,139,141,199$

Lindgren, G., 143

Line, M. B., 104-5

loans, student, 164-5

Lodahl, J. B., 18

Lodge, D., 14-15

Löfgren, K.-G., 26, 132, 133, 134, 140,141

Lorn Foundation, 24

Lotka's law, 109

Lovell, M. C., 235n

Luckmann, T., 17

Lund University: 19, 26, 133, 142, 150-1, 198; Ph.D. degrees, 73;

Ph.D. students, 76, 80; Ph.D.

theses, 92, 93; research grants, 55 , $56,59,61,63,64,66$; research profile, 120,121

Lundahl, M., 27, 138

Lundberg, E., 24, 25, 36-7, 43, 46, $48,77,87,153,242 n$

Lundgren, S., 143

Luukkonen-Gronow, T., 3-4, 234n

Lybeck, J., 26, 140

Lyttkens, C. H., 142

McCain. C. W., 118
McCloskey, D. N., 4, 17, 18, 235n, 236n

macroeconomics research, 26,132 , $136-7,140,153-4$

Măler, K.-G., 26, 116, 134

Malinvaud, E., 17, 18, 233n, 236n

March, J. G., 23n

Marion, N., 136

market: for economics doctors, 94-102, 145-6; for professors, 20-8

Markusen, J., 136

Marxism, influence of, 45

microeconometrics research, 156

microeconomics research, 136 , 142-3

Mitroff, I., 17

mobility between universities,

149-50, 169-70, 173

monetary economics research, 26 , 141-2

monographic theses, 168-9, 173, 185

Montgomery, A., 25

Myhrman, J., 26

Myrdal, G., 24, 25, 36, 37, 38, 40, $43,46,87,116,199$

National Income project, 24

National Institute of Economic

Research, 9, 148, 153-4, 158

natural resources research, 133-5

Nyquist, H., 140

objectivity of evaluations, 6

Office of Swedish Higher

Education (UHÅ), 4, 6, 49, 53

Ohlin, B., 24, 25, 36, 38, 39-40, 43, $46,87,116$

Olsen, J. P., 233n

Olsson, W., 197

open economies, research on, 27 , 141

opponents, faculty, 88-91, 103

organization of research, $7-8,16$, $145-58,174-86$

overseas fellowships, 183-4

Palander, T., 38, 74, 87

parochialism 169; see also inbreeding

Pasinetti, L., 18 


\section{Index}

Pedersen, K. M., 17

Pedersen, M. N., 4

Pelikan, P., 143

Persson, I., 133

Persson, M., 27, 138, 141

Persson, O., 123

Persson, T., 27, 136, 137, 139, 141

Persson, U., 143

Petander, K., 37

Ph.D. degrees, 68, 69, 70-1, 73-4, $78,81-3,102$

Ph.D. students: 72, 75, 76-7; age of, 80-3, 85; financial support for, $78,79,164-5,184-5$; supervision of, 36-7, 77, 162; women as, $83-4,85,87,93,103$

Ph.D. theses: $28,30,68,69,70$, 71-9, 102; form and content of, 86-8, 168-9, 173, 185; language of, 87-8, 103, 173; monographic, 168-9, 185; topics of, 91-4, 103

Philip, K., 35

Phillips, Sir David, 14

Pigouvianism, 43

politics, involvement of professors in, 40, 44-5

Portes, R., 5, 39, 242n

postgraduate education: $13,15-16$, $33,68-71,159-70,180-6$; see also licentiate degrees; Ph.D. degrees; Ph.D. students; Ph.D. theses

Powell, W. W., 18

preacher role of economists, 12

principal-agency problem, 6

private foundations, 52

private sector: earnings in, 96, 97, 99; economics doctors employed in, 95,146

process of evaluation, 8-11

professional competence, acquisition of, 30-1

professors: 177-8, 189-95; age at appointment, 34, 35; animosity between, 37-8; emigration of, 356; extramural activities of, 39-45; participation in government work, 41, 43; international contacts and influences, 36, 45-7; intramural activities of, 33-9; participation in public life, 39-45; involvement in politics, 40, 44-5; publication by, $39-40,41,42-3,45-6$;

qualification and selection of, 28-33; status and influence of, 33; supervision of doctoral students, 36-7, 77; teaching by, 167-8; tenure of, 33; university market for, 20-8

professorships, creation of, 167-8

public finance research, 138-9

public life, participation of professors in, 39-45

public sector: earnings in, 96, 97; economics doctors employed in, 95,146 ; research on growth of, 26 publication: $14,30,39-40,41,42-3$, 45-6; international, 104-26, 171-2; language of, 106

Puu, T., 9, 134, 135

qualitative methods of evaluation, 6 quality control, 155, 156

quasi-experimental evaluations, 5-6

Radetzki, M., 134, 137

Razin, A., 137

regional economics research, 26,135

research assistants, 165

research councils, $4,50-1$

research degrees see doctoral

degrees; licentiate degrees

research grants, allocation of, 13, 49-66, 156, 172

research groups, 175-6

research institutes: 147; doctors of

economics employed in, 95; links with university departments, 176-7; non-university-based, 153-5; university-based, 147, 151-3 research output, 8 research profiles, $118-25$ research system: 7-8; see also organization of research resource allocation, 13, 49-66, 156, 172

resource economics research, 133-5 responsiveness of evaluations, 6 routine studies, $155,178,179$

Russell, C. S., 138 
Rydqvist, K., 142

scale: of postgraduate programmes, $160-4,172-3$; of research programmes, 148,172 Scandinavian Journal of Economics, 41, 46, 110, 125

scholarly research, 155-6, 178-9

scholarships: $165,166,173$; see also fellowships

Schön, D. A., 18

Silverstolpe, G., 37

Siven, C.-H., 26, 142

Skogh, G., 142

Snickars, F., 116

Snower, D. J., 131, 132, 14

Social Science Citation Index, 106

Social Scisearch, 106

Södersten, B., 40, 137

Solow, R. 5, 235n

Sommarin, E., 24, 36

specialization, 156-7, 178

Stähl, I., 26, 44

stakeholders, 6, 7

Steffen, G., 20, 240n

Stenkula, P., 53

Stern, P., 123, 124

Stigler, G. J., 4, 12

Stockholm School, 24-5, 36-7, 43, 45-6

Stockholm School of Economics (HHS): 9, 19, 20, 26, 28, 96, 100, $134,138,147,148,162,165$, 196-7; Ph.D. degrees, 73, 74; Ph.D. students, 76, 80; Ph.D. theses, 93; research grants, 54, 55, $56,59,61,63,64,66$; research profile, 121, 122, 123

Stockholm University: 20, 26, 148, 162; Ph.D. degrees, 73; Ph.D. students, 76, 80; Ph.D. theses, 92, 93; research grants, $55,56,59,61$, $63,64,66$; research profile, 120 , $121,122,123$

Stuart, C., 139

supervision of doctoral students, $36-7,77,162$

Svennilson, I., 24, 25, 26, 46

Svensson, L.E.O., 27, 109, 116, 136, $137,140,141,142$
Svensson, L.-G., 139, 141, 142

Swedenborg, B., 138

Swedish Agency for Research Cooperation (SAREC), 52

Swedish Confederation of Labour, 131

Swedish Council for Building Research, 52

Swedish Council for Research in the Humanities and Social Sciences (HSFR), 4, 51, 59

Swedish Institute for Social Research (SOFI): 9, 26, 78, 131, 131-2, 147, 152, 153, 158; research grants, $55,56,59,63,64$, 65,66 ; research profile, 121,122 , 123

Swedish International Development Agency (SIDA), 138

Swedish Journal of Economics, 41, 46

Swedish Work Environment Fund, 52

Tabellini, G., 139, 141

Tasiran, A., 140

taxation research, 138, 139, 141

teaching: 177 ; by economics doctors, 166-7, 173-4; by postgraduates, 164, 165, 184; by professors, 167-8

theses, see Ph.D. theses

Thurgood, D. H., 80

tied funding, 156, 158

trade research, 135-7

Trade Union Confederation, 61

Trade Union Institute for Economic Research (FIEF), 9, 62, 131, 132, $148,153,158$

tradition in postgraduate education, $168-70,173$

trustworthiness of evaluations, 6

Umeå University: 26, 96, 100, 134, 135, 161; Ph.D. degrees, 73; Ph.D. students, 76, 80; Ph.D. theses, 92, 93; research grants, 55 , $56,63,64,65,66$; research profile, $119,120,121$

undergraduate education, 160

Unemployment Committee, 24 


\section{Index}

United States: influence of: 47;

Ph.D. degrees, 78, 84-5, 166;

Ph.D. students, 80 ; professorial candidates in, 32

university departments: 146-7, 148-51; links with research institutes, 176-7

university-based research institutes, $147,151-3$

university system: inbreeding in, 149-50, 169, 173, 179; mobility in, 149-50, 169-70, 173

Uppsala University: $19,20,26,100$, 133, 148, 161; Ph.D. degrees, 73; Ph.D. students, 76, 80; Ph.D. theses, 93; research grants, 55,56 , $59,63,64,65,66$; research profile, 119, 120, 121

Van Duyne, C., 137

Wadensjö, E., 26, 99

wage determination, research on,

$131,132,133$

Wallenberg group, 196

Weibull, J., 141, 142, 143

Weinberg, A. M., 8

Weinman, J. M., 80

welfare economics research, 26

Werin, L., 37, 142

West Germany, 107

Wicksell, K., 19, 20, 23, 24, 36, 38, $39,40,45,87,240-1 n$

Wigforss, E., 45

Wihlborg, C., 27, 142

Wohlin, N., 37, 40

Wold, H., 28, 115-16, 139, 140

women economists, 83-4, 85, 87, 93

103; earnings of, 96, 97, 99, 103

Wredin, A., 142

Ysander, B.-C., 9, 26, 37, 233n

Zetterberg, J., 133

Zetterblom, G., 67 